
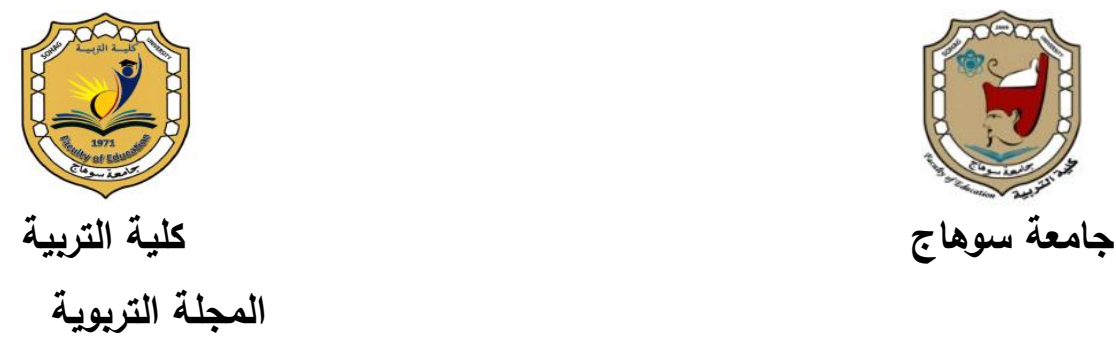

\title{
تطوير هنهج تخطيط وإدارة الإنتاج لتنمية هفاهيم اقتصاد المعرفة لدى طلاب المدرسة الثانوية الصناعية
}

\section{إعداد}

د/ أشرف قتحى محمد على

أستاذ المناهج وطرق التدريس المساعد

كلية التربية - جامعة حلوان

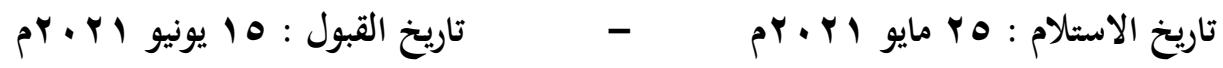




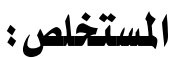

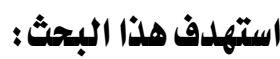

تعديد مفاهيم اقتصـاد المعرفة اللازمـة لطلاب تخصص الزخرفة والإعلان بالمدرسـة الثانوية الصناعية، ووضع تصور مقترح لمنهج مطوَر في تخطيط وإدارة الإنتاج ينمي هذه هـه المفاهيم لاى هؤلاء الطلاب، ويعد إعداد المنهج المطور تم اختيار وإعداد وحدتين من وحداته مفئه

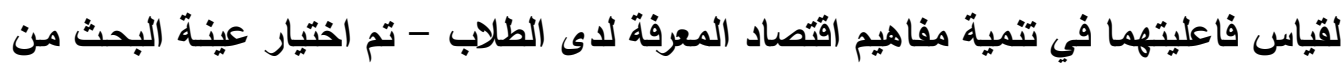

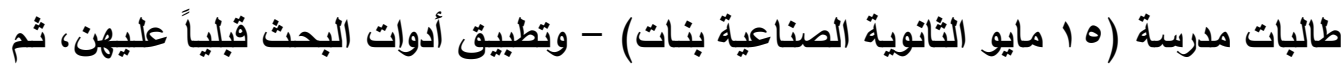

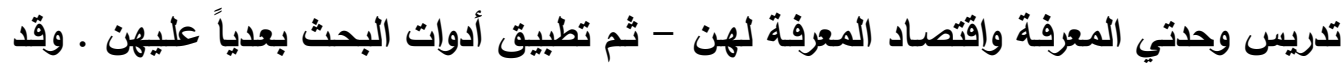

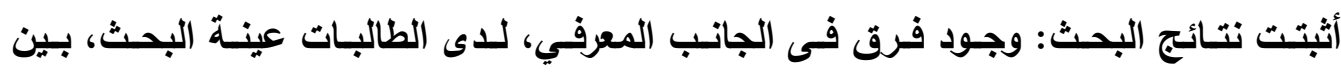

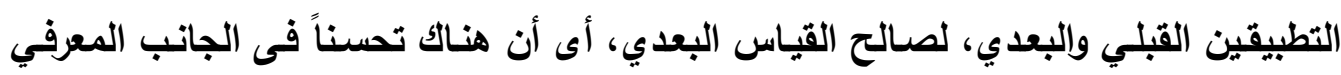

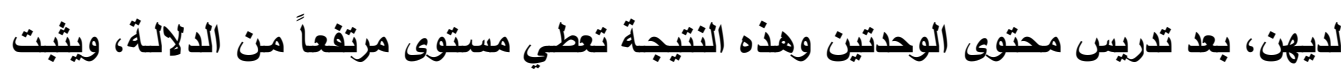

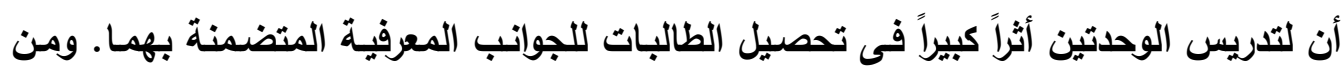

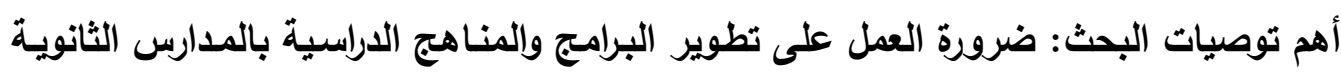

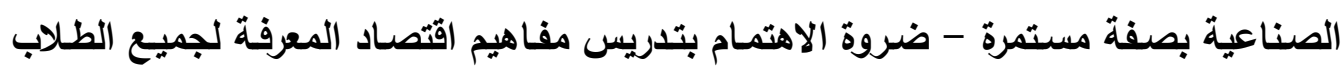

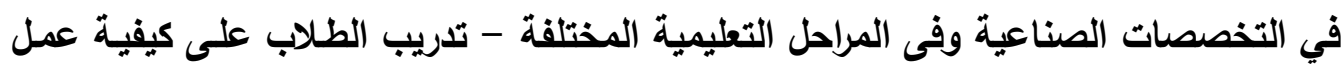
دراسـات الجدوى للمشـروعات الصـيرة في جميـع المراحل التعليميـة - اعتبـار المشـروعات الصناعية الصغيرة منطلقاً لتحقيق التمية الاقتصادية والاجتماعية في مصر . الكلمـات المفتاحيـة: اقتصـاد المعرفة - المدرسـة الثانويـة الصناعية - تخطيط وإدارة

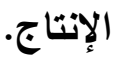




\title{
Search title
}

\section{(Development of production and planning management curriculum to develop knowledge economy concepts for industrial secondary school students)}

\author{
Prepare \\ D. Ashraf Fathy Mohamed Ali \\ Assistant Professor of Curriculum and Instruction \\ Faculty of Education - Helwan University
}

This research aimed: Defining the concepts of the knowledge economy necessary for students of decoration and advertising in the industrial secondary school, and developing a proposed conception for a developed curriculum in production and planning management that develops these concepts for these students, and after preparing the developed curriculum, two of its units were selected and prepared to measure their effectiveness in developing the concepts of a knowledge economy. The student sample of the research was chosen from female students of the (15th of May Industrial Secondary School for Girls) and apply research tools on them, then teaching them the units of knowledge and the knowledge economy. And then applying the research tools on them again. Research results: proved that there is a difference in the cognitive aspect of the female students in the research sample, between before and after applications, in favor of the after measurement, which approved that there is an improvement in their cognitive aspect, after teaching the content of the two units. This result gives a high level of significance, and proves that the teaching of the two units has a significant impact on students' achievement of the cognitive aspects included in them. Important recommendations: work continuously on developing curricula in industrial secondary schools - Teach the concepts of the knowledge economy to all students in industrial disciplines - training students on how to conduct feasibility studies for small projects at all educational levels - considering projects the small industrial sector is a starting point for achieving economic and social development in Egypt.

Keywords: knowledge economy - industrial secondary school - production and planning management. 
يمر عالمنا اليوم بالعديد من التطورات والتتيرات والمستجدات المتسـارعة فى كافة الثئون العالمية ولاسيما الثئون الاقتصادية، وتكنولوجيا المعلومات والاتصالات، ولعل أبرز التطورات والتغيرات المعاصرة التي فرضت ومازالت تلقي بظلالها بقوة على كافة الاقتصاديات الدولية

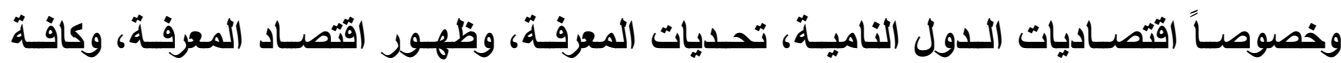

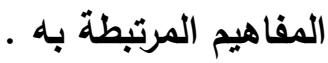

لقد تسببت ثورة المعلومـات والاتصـالات فى تضـاعف المعرفة الإنسـانية وفى مقدمتها المعرفة العلمية والتقتية وكان من نتيجة ذلك تحول الاقتصاد العالمي إلى اقتصاد يعتمد على

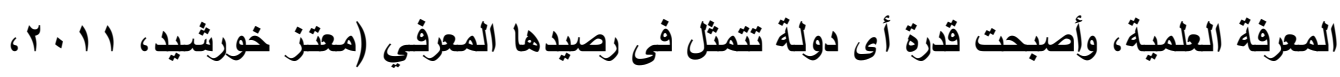
$\cdot(r v$ إن أهم مـا بشــل الاسـتراتيجيات الدوليـة في هذه الآونـة هو السـعي لضـمان الاستـامة

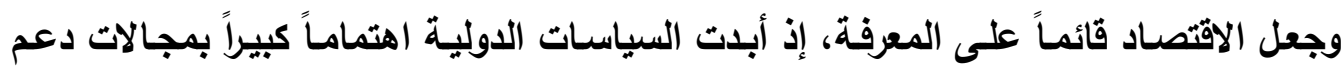
الأعمال ومجالات الإنتاج بمختلف تصنيفاتها، كإحدى أهم ركائز التنمية. وفي هذا الإطار تبرز أهمية الأعمال بشكل عام، والأعمال المستدامة بشكل خاص؛ لاصنه لكونها

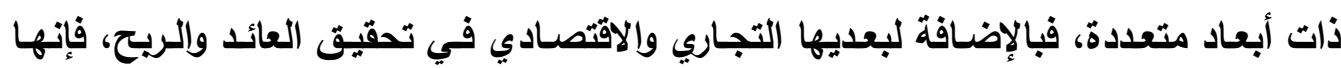
تشمل أيضاً البعد البيئي، من حيث الحفاظ على الموارد وعدم الإضرار بالبيئة، فضلاً عن البعد

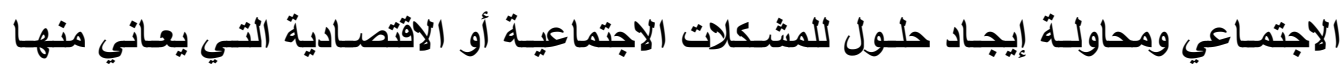

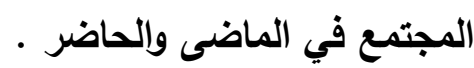
وحيث إن اقتصاد المعرفة يرتكز على المعرفة، والمعرفة ترتكز فى اكتسابها على التربية؛؛

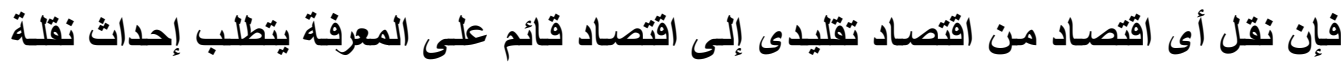
وتحول تريوي نوعى بلداً من الحصول على المعرفة ونشرها ومروراً بإنتاج المعرفة وتوظيفها

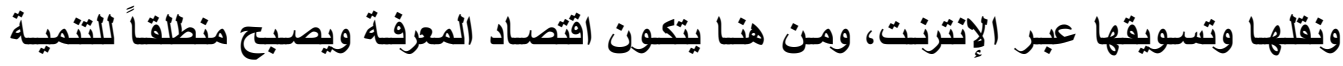

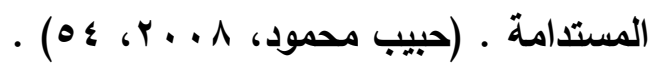
وتعتمــ تنميـة المجتمعـات اعتمـاداً كبيراً على وجـود نظـام تعليم راقـى النوعيـة، ويصـب الحفاظ على قيم المسـاواة والديمقراطية دون أن يوفر المجتمع للمواطنين مستوى جيداً من التعليم، هذا فضـلاً عن أن المستويات المتميزة للتعليم ضرورة للازدهار الاقتصـادى وخاصـة 
من خلال تكوين قوة عمل ديناميكية ذات مرونة ومهارة عالية، وتكاد تكون الحاجة إلى العامل غير المـاهر تختفى فـى الاقتصـاديات المتقدمـة التـى تـأثرت بالعولمـة والثـورة التكنولوجيـة

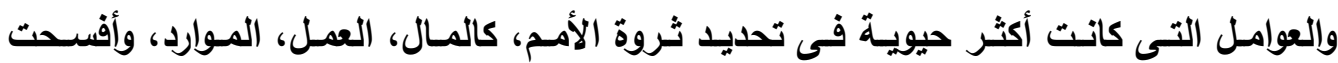
الطريق لعوامل جديدة هى معرفة قوة العـل واتجاهاتها ومهاراتها، ولا تستطيع أمسة ترغب فى في

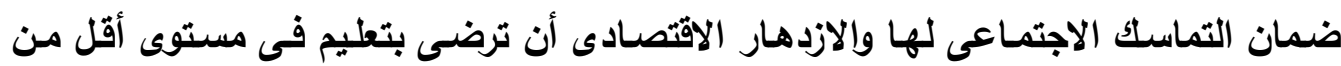
المستوى العالمى المتقدم - المبن ويرتبط النظام التعليمي في المجتمعات المتقدمة بالنظام الاقتصادي فالعلاقة وثيقة، ومن المعروف أن التعليم الجيد يوجهه سلوك الفرد نحو ترشيد الإستهلاك وزيادة الإنتاج والارتقاء بجودته، كما أنه يرتبط بهيكل سوق العمالة وإلتنمية الاقتصادية والاجتماعية، فوصول سوق لرقيل

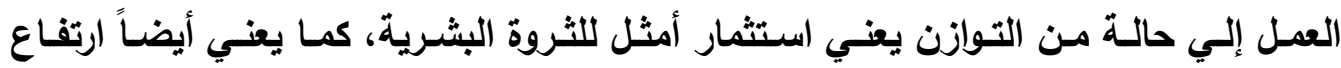

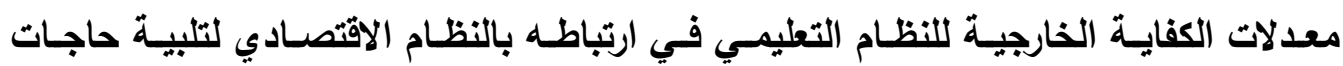

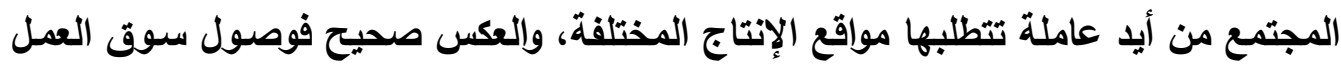

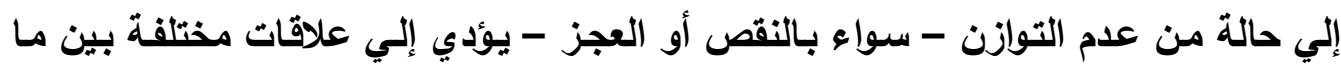

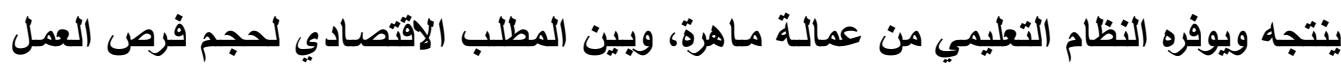

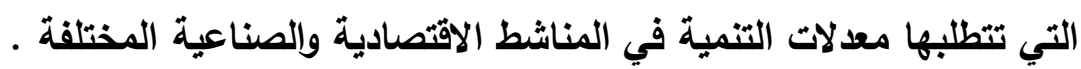

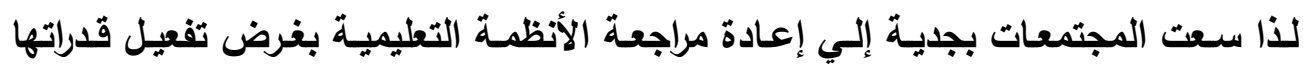

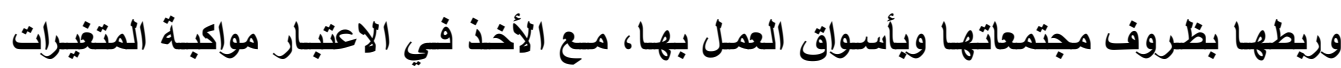

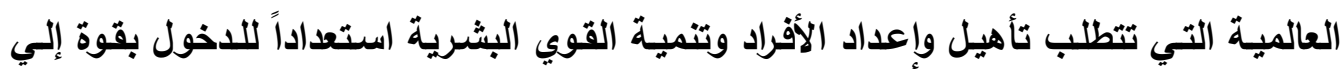
متطلبات الألفية الثالثة، كما قامت الدول المتقدمة صناعياً بتطبيق صيغ متعددة تهرف إلى البي ربـ تلك المـارس بمختلف تخصصـاتها بسـوق العدل، لتحقيق فلسفة (مسن المدرسـة إلـي العمل) بهاف مسـاعدة الطلاب علي اكتسـاب المهارات التي تحقق رغبات واحتياجـات سوق

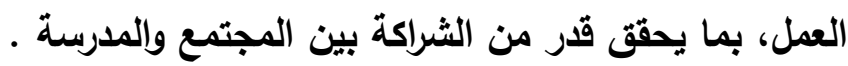

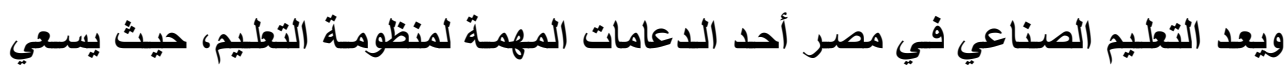

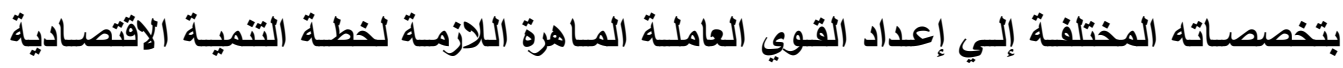
والاجتماعية للاولة ويلبي احتياجات سوق العمل ـ وتعتبر فترة تعلم الطلاب بالمدارس الثانويـة الصناعية من أهم فترات اكتسـاب المفاهيم وتعلمها، وتكوين المهارات العملية والتكنولوجيـة 
فهي فترة التعرف والتعليم والاستطلاع والممارسـة والتجريب، يستمتع فيها الطالب بالأعمال

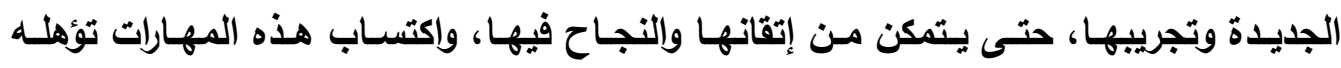

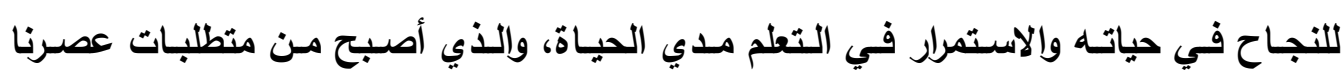
الحالي.

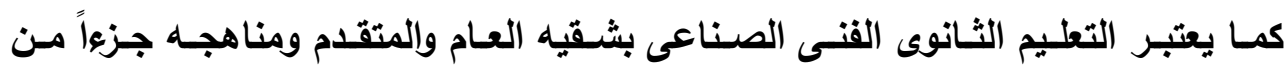

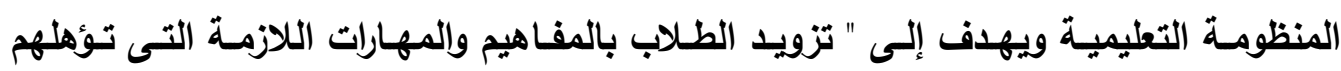

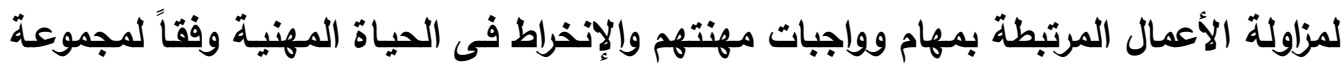
من المعايير ويما يتناسب مع التطورات المجتمعية على كافة الأصعدة السياسية، الاقتصادية،

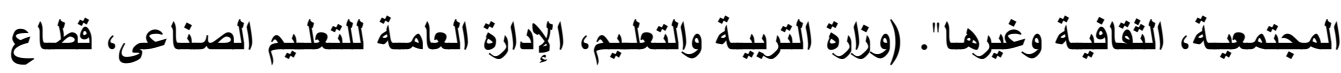

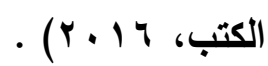
ويعد تخصص الزخرفة والإعلان بالمدرسـة الثانويـة الصناعية أحد التخصصـات الهامـة، والذى يتميز بتعدد أعماله وتتوع مجالاته واستيعابه للكثير من الطلاب لإعداد الفنـي والقنى لإنى

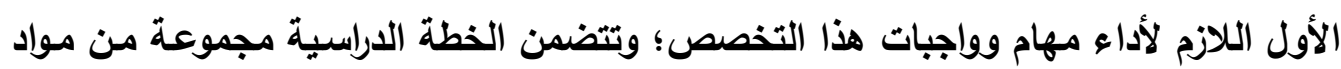

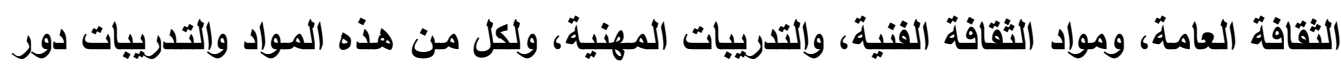
أساسى فى تزويد الطلاب بالمعارف والمفاهيم والمهارات والقيم والاتجاهات التى يفترض وأن ولنهات

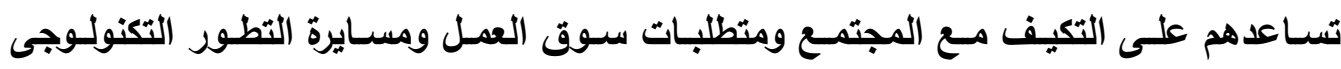

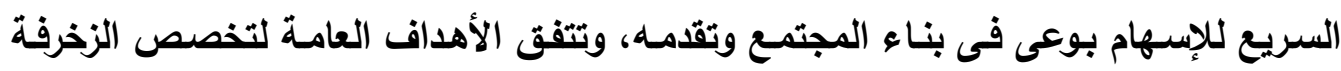

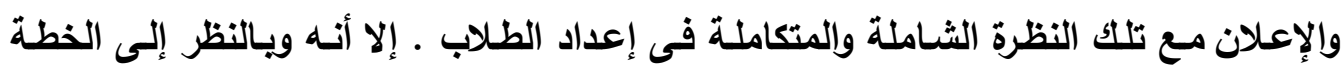

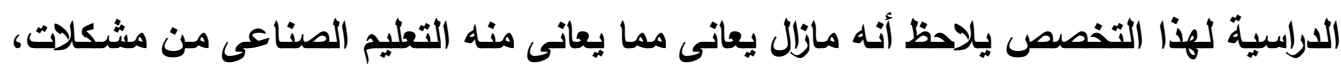

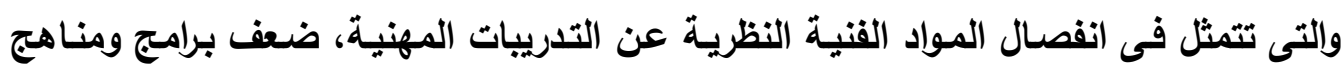

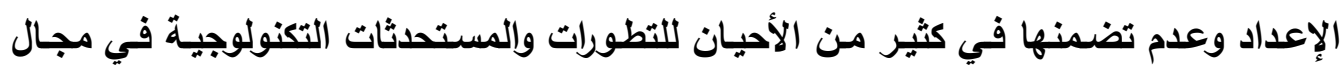
التخصص، وأن تدريس هذه المنـاهج والمقررات مازال يركز على الحفظ والتلقين والاستظهار

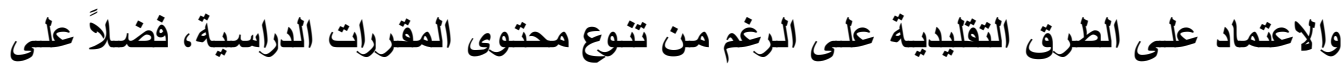

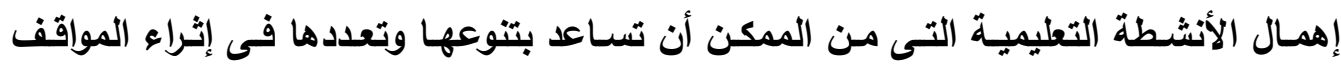
التعليمية للموضوعات الاراسية المختلفة . المبطه 
والمتتبع للاتجاهات الحديثة في التربية يلاحظ أنها قد تحولت من التركيز على مـاذا نعلم

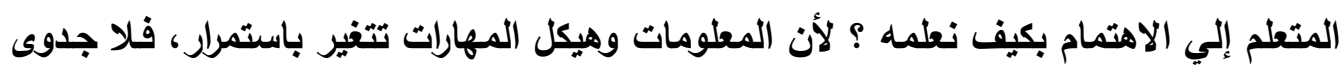
من تخزينها في عقول الطلاب، بالإضافة إلي أهمية عرض المشكلات المختلفة علي الطلاب،

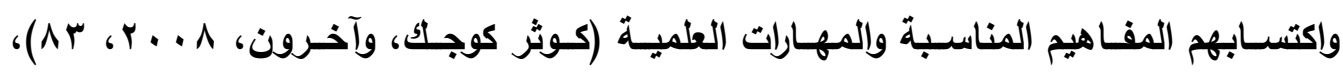

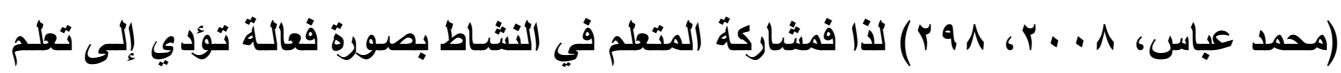

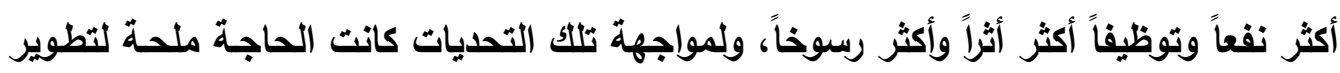

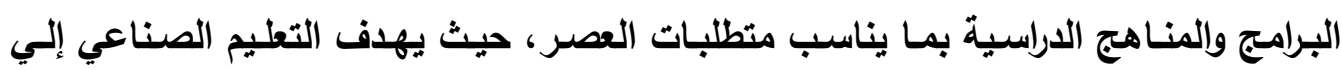

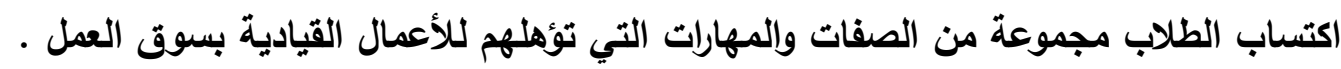

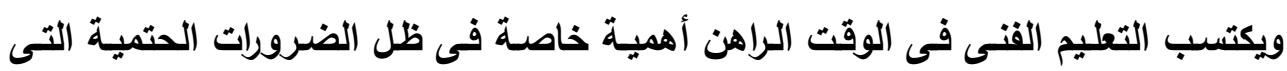

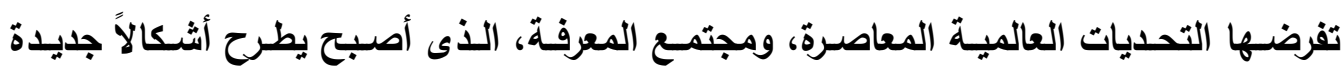

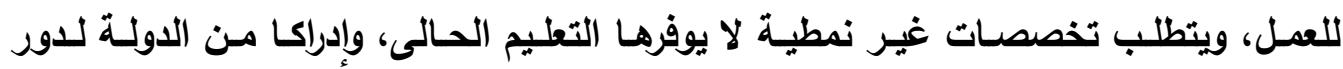
التعليم القنى المحورى فى تحقيق التنمية، تم البدء فى تطبيق منظومـة جليدة لتطوير التعليم

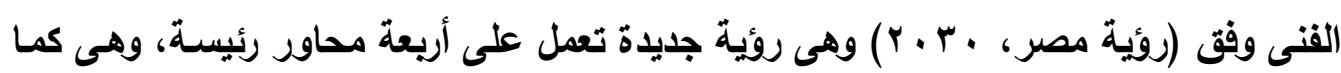
يلى 1 - الاهتمـام بالمؤسسـات التعليمية (مدارس التعليم القتـي) ومـا تتطلبه من مصـادر للتعليم والتدريب، ومعامل، وورش تعليمية وإنتاجية، ومعدات وأجهزة .

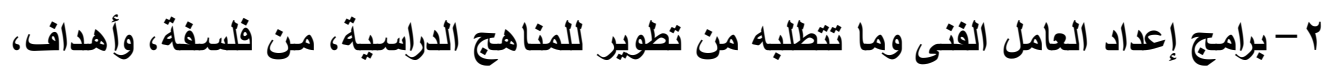
ومحتوى، وأساليب التعليم والتدريب، ومصادر التعلم، وتقويم الجوانب المختلفة.

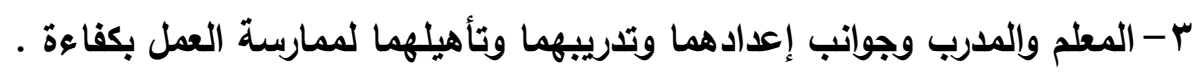
ع - ريط مخرجات مدارس التعليم الفنى بسوق العمل وكافة مؤسسات المجتمع المدنى للوفاء

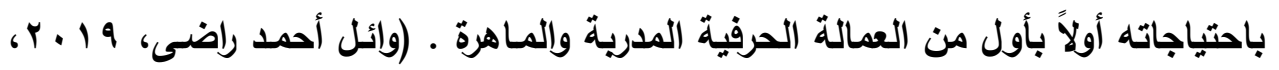
- (r ويتناول البحث أحد المحاور الرئيسة السابقة، والمتعلق بتطوير برنـامج ومناهج إعداد العامل القني الصناعى بما يساعد فى تحقيق جودة عمليات الإعداد بطرق فعالة، وتقديم خريج يلبى متطلبات

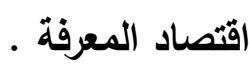


ولكن بدراسة الوضع الحالي لبرامج إعداد العامل الفني بالمدارس الثانويـة الصناعية تبين

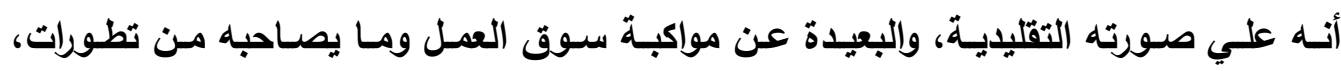

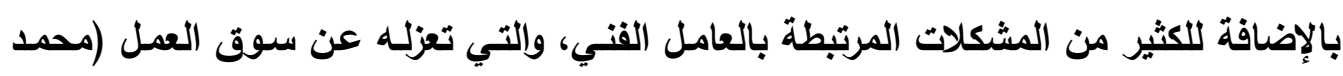

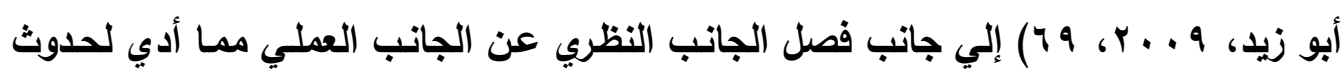

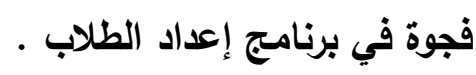

الإحساس بالمشكلة:

استشعر الباحث بمشكلة هذا البحث من خلال مايلي:

أولاً : الخبرة الشخصية: الثبة

استثنر الباحث بوجود مشكلة البحث من خلال الخبرة الشخصية والتدريسية والتي تصل

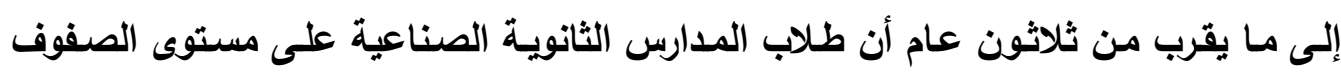

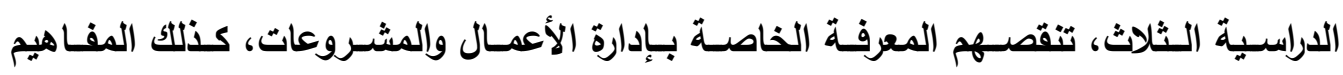

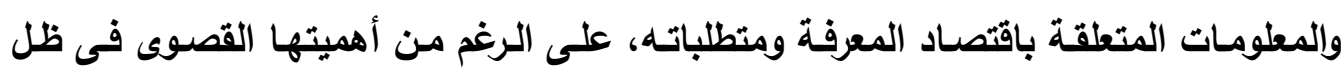

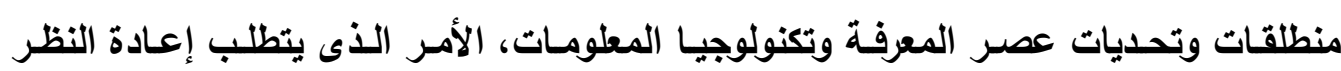
ويسرعة لتدارك هذا الأمر والسـعى الحثيث لإكسـاب الطلاب مهارات التعامل مـع تلك المفاهيم

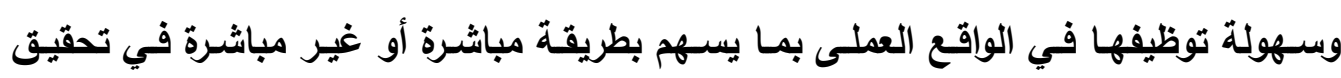

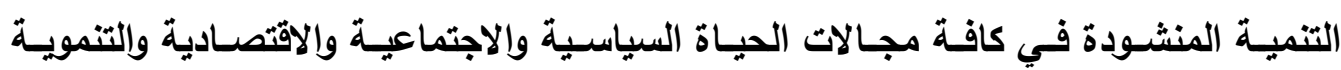

والبيئية .

ثانياً : الاطلاع علي نتائج وتوصيات الدراسات والبحوث السابقة : حيث أكدت العديد مـن الدراسـات والبحوث على أهميـة تطوير النظم التعليميـة وتدريس المفاهيم الخاصة باقتصاد المعرفة، وضرورة إعداد الطلاب للتعامل مع هذه المفاهيم وتوظيفها

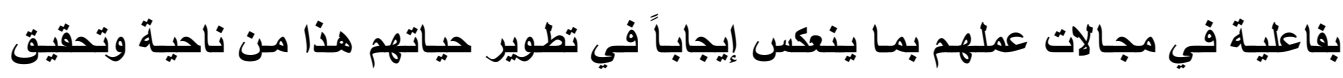
نهضة مجتمعاتهم من ناحية أخرى، ومنها:

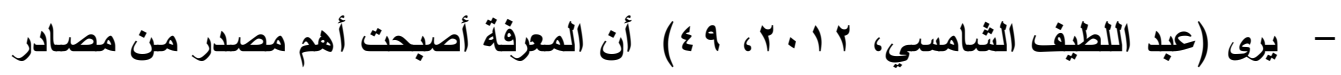

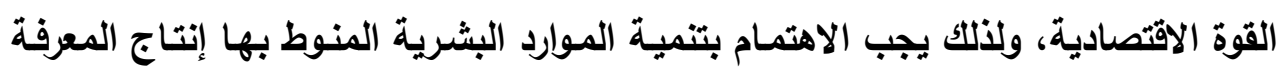

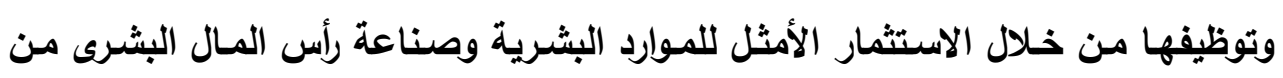
أجل الاخول لعصر الاقتصاد المعرفى. 
- يؤكد كل من (2014, Kivinen \& Nurmi) على أهمية السياسـات التعليمية التى تهنتم بالاسـتثمار فـى رأس المسال البثـري والتنميـة البشـرية والعمـل على إعداد الأفراد لاحتياجات اقتصاد المعرفة وتخريج الطلاب استجابة لاعم التنافسية الاقتصادية المعرفية

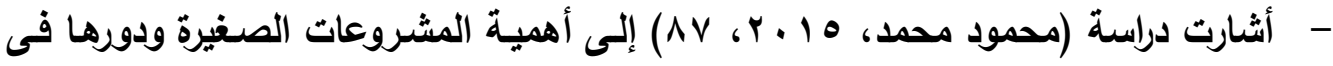
دعم عمليات التنمية الاقتصـادية والاجتماعية بمصر، وقد توصلت الدراسـة إلى ضرورة العــل على ترسـيخ ثقافـة ريـادة الأعمـال، لــل مشـكلة البطالـة، الاســفادة مـن دور المشروعات الصغيرة فى ظل اقتصاد المعرفة . - - يرى(Gul, Showkeen, 2015) أن أحد المتطلبات الأساسية للتعلم فى العصر الحسالى هـو إعداد الأفراد للمشـاركة فـى اقتصـاد قـائم على المعرفـة مـن خـلال التعلم الإلكتروني الأي يشكل حجر الزاوية لبناء مجتمع المعرفة، واستخدام تكنولوجيا المعلومـات فـى عمليـة التـطم والوسـائط الإكترونيـة مـن أجلـل الوصـول بالمنـاهج التعليميـة خـارج الفصول التقليدية . - يشير (Obielumani, 2015, 74) إلى أهمية الاستثمار فى التعليم وضرورة توفير التمويل الـلازم وتكنولوجيا المعلومـات، كذلك دور التعليم والبحث العلمى كأسس داعمـة التهـ للتحول نحو اقتصاد المعرفة .

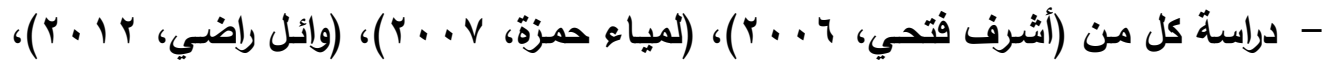

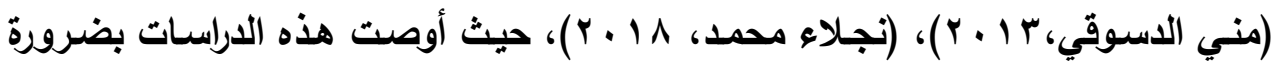
تطوير برامج ومناهج التعليم القني الصناعي في ضوء الاحتياجات المهنية لسوق العـل والتطورات المعاصرة به . - إيمانـاً بأهميـة ودور المنهج فـى إعداد الطلاب بالمراحل الدراسية المختلفة بشكل عام، وطلاب مدارس التعليم القنى الصناعى بشكل خاص، ودوره فى تحسين مخرجاتها فقد أصدر مركز خدمات المناهج بكندا (Services in Canada Curriculum) مجموعة مـن الوثائق أكدات جميعهـا على أهميـة مواكبـة المنـاهج الدراسـية لتطلعـات وتغيـرات المستقبل، (258: 265 - Robert Marzin0 2012 وملاحقة تطوراته المذهلة في هون شتى مجالات العلم، كما أكدت على أهمية رصد وتحليل الواقع بما يتضمنه من نجاحات 
وإخفاقـات ومـدى تأثيرهـا فـى وضـع ملامـح للمسـتقبل، وعلى حتميـة عمليـات التطـوير

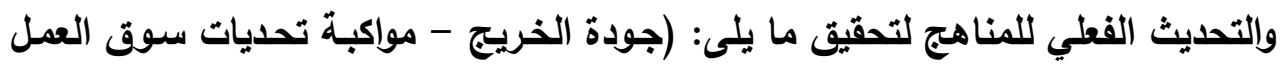
المختلفة فى شتى المجالات - مواجهة الصراعات والتنافسات بين الدول) .

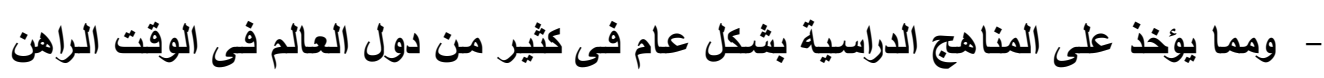
أنها تعد مخرجات القرن الحـالي بمتطلبـات القرن الماضـى فهي تفكر بأسـلوب خطى، وتعد أجيالاً تفتقد

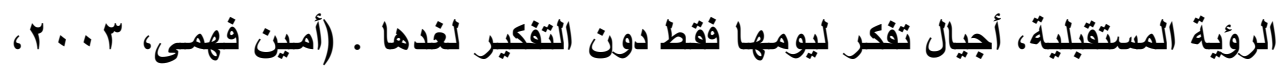
. (०9 ثالثاً: توصيات المؤثترات:

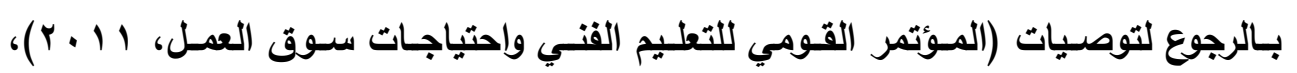

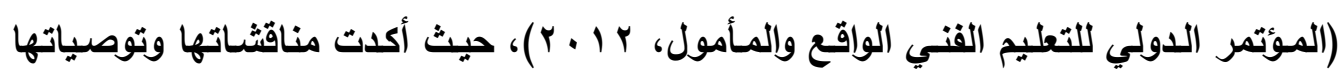

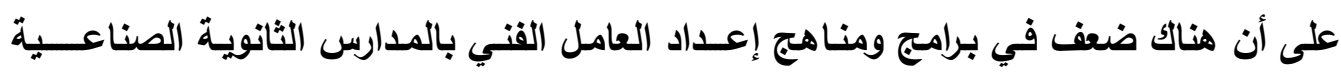

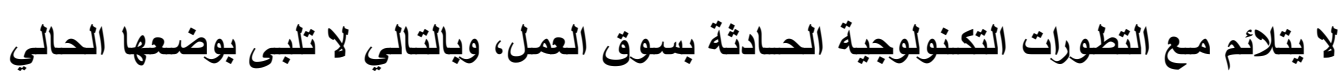

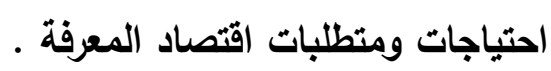
رابعاً: استطاعلاع رأى المعلمين والموجهين: تـم اسـتطلاع أى الخبـراء والمتخصصـين مـن المعلمسين والمـوجهين بالمدرســة الثانويـة الصناعية حول مدى مراعاة برنامج إعداد فني الزخرفة والإعلان بصورته الحالية للمتغيرات

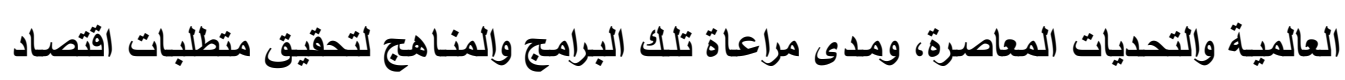

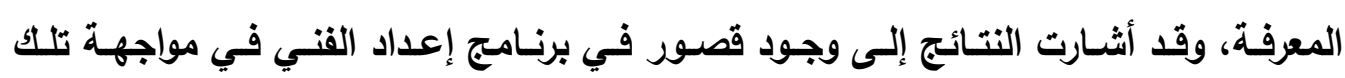
التحديات العالمية، ومازالت الكتب المدرسية على وضعها الحالي تستخدم الممارسـات التقليدية سواء في إعداد وتقديم المحتوى أو تنظيمـه أو في تدريسـه، ويالتالي يصسب على علي الطلاب

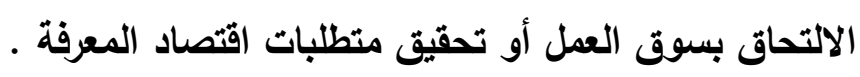

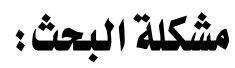

تمثلت مشكلة البحث في: ضعف مفاهيم اقتصـاد المعرفة لدى طلاب تخصص الزخرفة

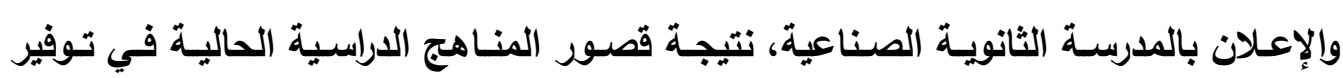

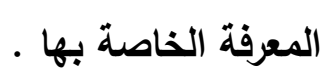




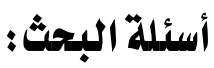

1- ما مفاهيم اقتصاد المعرفة اللازمـة لطلاب تخصص الزخرفة والإعلان بالمدرسة الثانوية

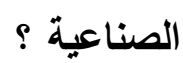

r - ما أسس بناء منهج مطور في تخطيط وإدارة الإنتاج لتنمية مفاهيم اقتصاد المعرفة لاى

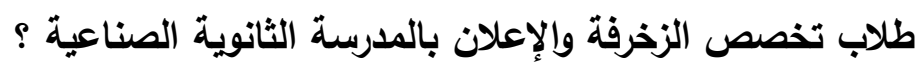

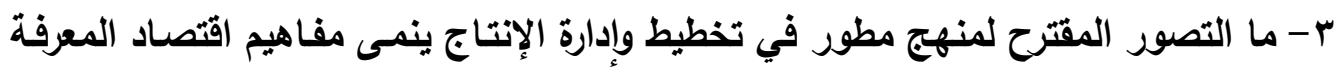

لاى طلاب تخصص الزخرفة والإعلان بالمدرسة الثانوية الصناعية ؟

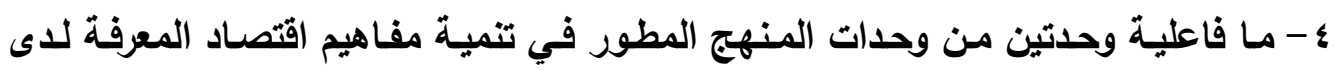

طلاب تخصص الزخرفة والإعلان بالمدرسة الثانوية الصناعية ؟

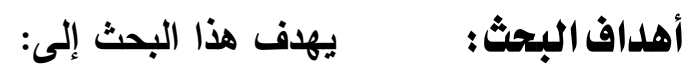

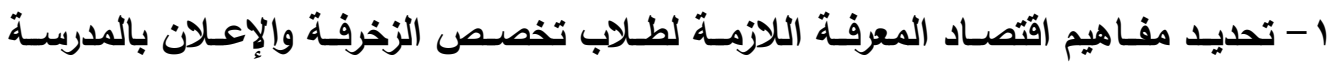

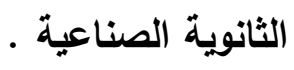

r r ت بديد أسس بناء المنهج المطور في تخطيط وإدارة الإنتاج . r- وضع تصور مقترح لمنهج مطور في تخطيط وإدارة الإنتاج ينمى مفاهيم اقتصاد المعرفة لاى طلاب تخصص الزخرفة والإعلان بالمدرسة الثانوية الصناعية . ع - قياس فاعلية وحدتين من وحدات المنهج المطور في تتمية مفاهيم اقتصاد المعرفة لاى طلاب تخصص الزخرفة والإعلان بالمدرسة الثانوية الصناعية .

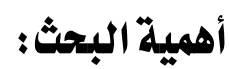

قد يفيد هذا البحث:

1- مخططى ومسئولى منـاهج التطليم الصناعى بمـا يضعاه مـن مقترحسات لتطوير البرامج

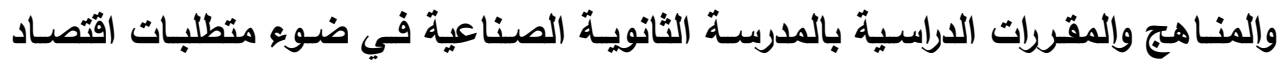

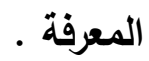

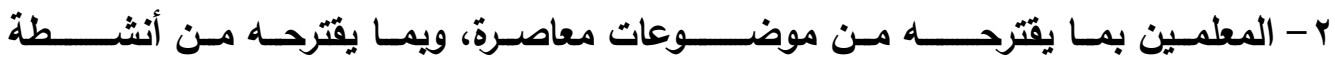
ووســائط تكنولوجية، تناسب بـانب

الموضوعات المطروحة وتتماشى مع متطلبات اقتصاد المعرفة . 
r- الطلاب بما يقدمه لهم من موضوعات ومفاهيم معاصرة تتماشس مـع إعدادهم الأكاديمى والقنى

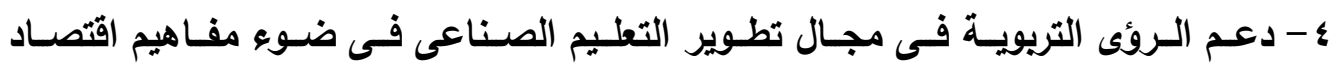
ومجتمعات المعرفة .

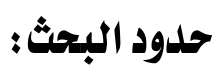
يقتصر البحث الحالي علي: - - حدود موضوعية: تطوير منهج تخطيط وإدارة الإنتاج من برنـامج إعداد فنى الزخرفة - والإعلان

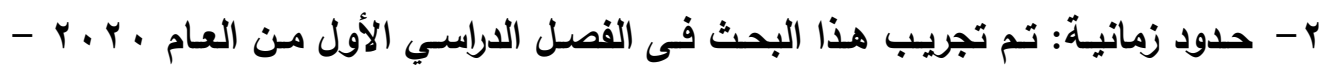
$\cdot r^{r} \cdot r_{1}$ r- حدود مكانية: تجريب وحدتين من وحدات المنهج المطور على عينة من الطلاب بإحدى

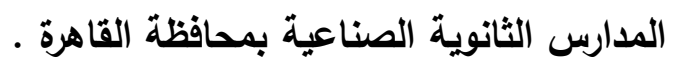
ع - حدود بشـرية: عينـة مـن طلاب الصف الثالث تخصص الزخرفة والإعـلان بالمدرسـة الثانوية الصناعية.

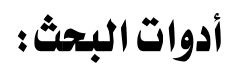
1 - اختبار معرفى للوحدة الأولى (المعرفة): لقياس الجوانب المعرفية المتضمنة بها ـ r - اختبار معرفى للوحدة الثانية (اقتصاد المعرفة): لقياس الجوانب المعرفية المتضمنة بها

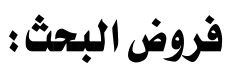
1 - يوجد فرق دال إحصائياً عند مستوى (1 . . ) بين متوسطى درجات الطلاب عينة البحث

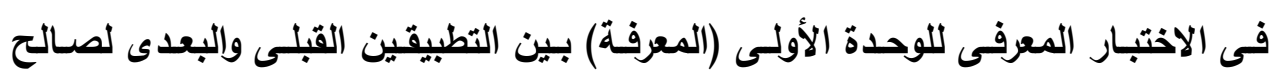
متوسط درجات الطلاب فى التطبيق البعدى.

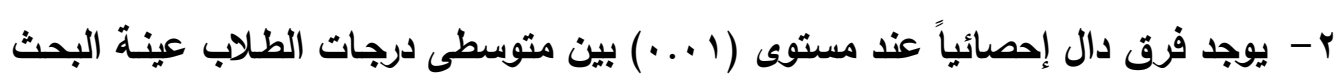

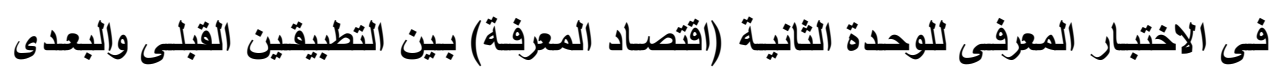

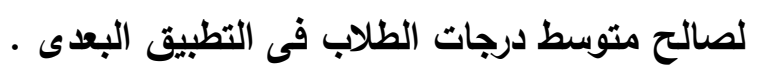




\section{منهج البحث وإجراءاته :}

الاطـلاع على الأدبيـات والبحـوث والدراسـات السـابقة المرتبطة بمحساور الإطـار النظرى للبحث، استخدام المنهج شبه التجريبى لتعرف فاعلية وحدتى (المعرفة)، (اقتصاد المعرفة) من وحدات مقرر الصف الثالث فى تنميـة مفـاهيم اقتصـاد المعرفة لـى عينـة مـن طـلاب تخصص الزخرفة والإعلان بالمدرسة الثانوية الصناعية، وسارت الإجراعات وفقاً لما يلى: أولاً : الإطار النظرى: وتضمن المحاور الآتية: - المحور الأول: تطوير المنـاهج الدراسية: (مفهومـهـ - مبرراتـهـ - اتجاهـات - أسس -

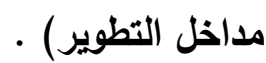

r- المحسور الثانى: اقتصـاد المعرفـة: (المعرفـة - اقتصـاد المعرفـة - أهميتهـه - ركـائزه خصائصd ....). r- المحور الثالث: المدرسة الثانوية الصناعية: (تعريفها - أهدافها) .

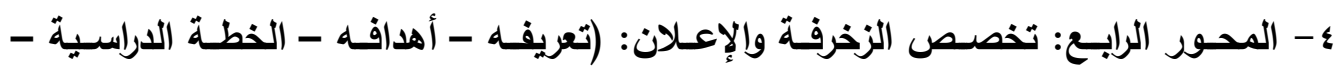
تخطيط وإدارة الإنتاج)

ثانياً : الدراسة الميدانية : 1 - تحديد مفاهيم اقتصاد المعرفة: - من خلال مجموعة من المصـادر، منها: الأدبيات والمراجع العلميـة والاراسـات والبحوث السـابقة المرتبطة، تحليل محتوى منهج تخطيط وإدارة الإنتـاج الحسالي، للتوصل إلى ملى

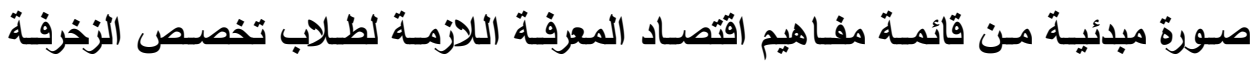

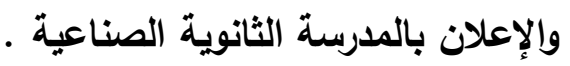
- عرض القائمة المبائية لمفاهيم اقتصاد المعرفة على السادة الخبراء والمتخصصين لأخذ

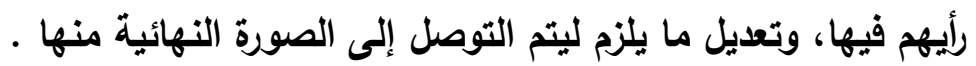

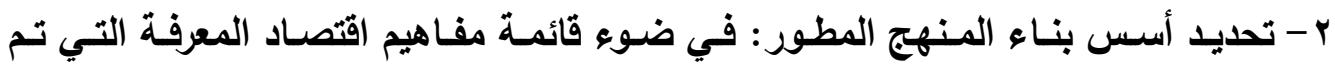
التوصل إليها - لمان r- وضع الإطار العام لمنهج تخطيط وإدارة الإنتاج: 
وقد تضمن المنهج العناصر التالية: فلسفة المنهج - الأسس التي يقوم عليها - الأهداف العامـة - الإطـار العـام للمنهج ويثـمل (الأهداف الإجرائية - المحتوى الدراسـى - الأنشطة التعليمية - مصادر التعلم - الطرق والإستراتيجيات التدريسية المستخدمة - وسائل التقويم).

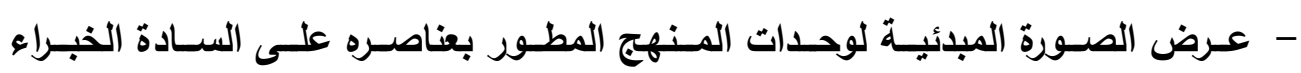
والمتخصصين في مجال المناهج وطرق التدريس والتعليم الصناعى لإبداء الرأي حولها. - تعديل مـا يلزم في ضـوء المقترحات المقدمـة، ومـن ثم التوصل إلى الصـورة النهائيـة للمنهج المطور - تعايل

ع - قياس فاعلية وحدتين من وحدات المنهج المطور:

- تم اختيار وحدتى (المعرفة)، (اقتصاد المعرفة) لتدريسهما وقياس فاعليتهما في تنمية

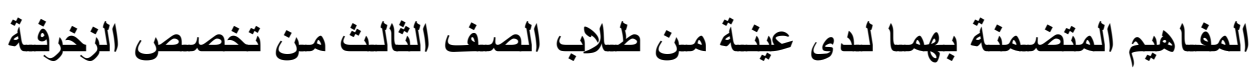
والإعلان بالمدرسة الثانوية الصناعية، وقت تضمنت كل وحدة العناصر التالية: (مقدمـة

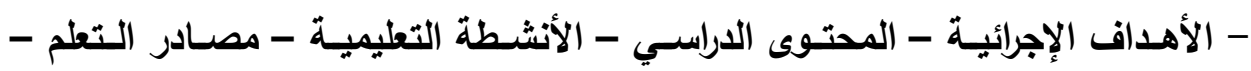
طرق واستراتيجيات التدريس - وسائل التقويم)، الزمن اللازم للتدريس . - عرض الوحدتين وأدوات تقويمهما على السـادة الخبراء والمتخصين في مجال المنـاهج وطرق التدريس والتعليم الصناعى، وتعديل ما يلزم في ضوء آراء السادة المحكمين .

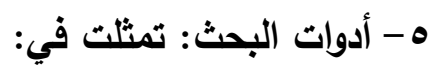
أ- اختبـار معرفى للوحدة الأولـى (المعرفة): لقيـاس مـدى اكتســاب الطـلاب للمفــاهيم

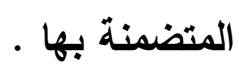
ب- اختبـار معرفى للوحدة الثانيـة (اقتصـاد المعرفـة): لقيـاس مـدى اكتسـاب الطـلاب

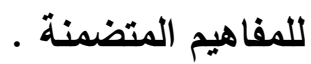

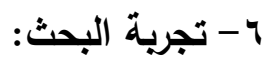

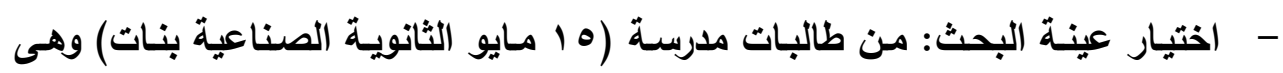

$$
\text { إحــدى المدارس عينه البحس }
$$

التابعة لإدارة المستقبل التعليمية بمحافظة القاهرة، نظراً لقربها من مكان عمل وإقامـة الباحث . - - تطبيق أدوات البحث قبلياً على الطلاب عينة البحث . 


$$
\begin{aligned}
& \text { - تلدريس وحدتى (المعرفة)، (اقتصاد المعرفة) للطلاب عينة البحث . } \\
& \text { - - تطبيق أدوات البحث بعدياً على الطلاب عينة البحث . ل } \\
& \text { V - نتائج البحث: التوصل إلى نتائج البحث ومناقشتها ـ } \\
& \text { 1 - توصيات البحث، ومقتزحاته . }
\end{aligned}
$$

مصطلحات البحث:

\section{1 - تطوير المناهج الدراسية: Curriculum development:}

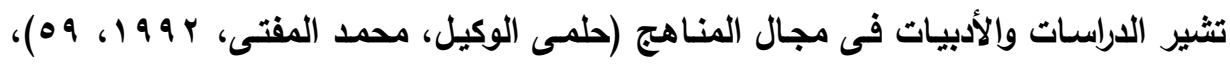

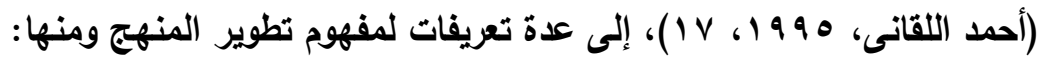

- يقصد بمفهوم تطوير المناهج: إدخال تجديدات ومستحدثات في مجالها بقصد تحسين العملية

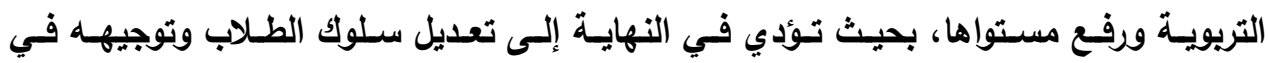

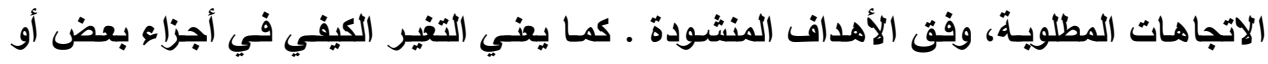

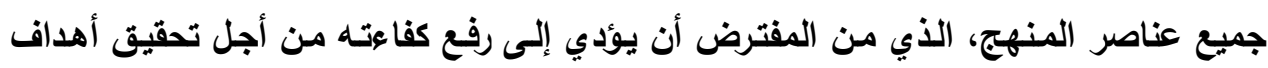

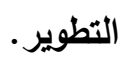

- ويعرف تطوير المنهج في هذا البحث بأنه: إدخال تجديدات وتحديثات في جميع عناصره ومكوناته بقصد تحسين العملية التعليمية والتربوية ورفع مستواها، بحيث تؤدى إلى الارتقاء بمستوى العامل

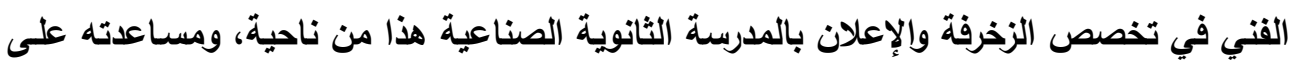

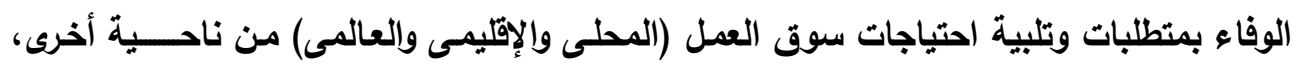

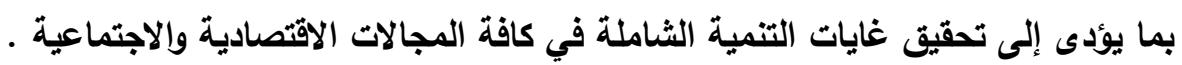

\section{: Knowledge : المعرفة}

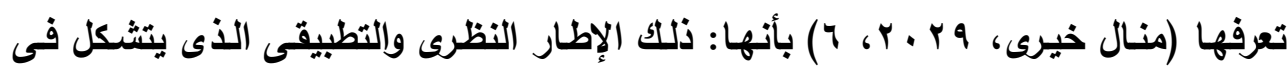
البنية المعرفية للفرد ويتكون من مجموعة من الحقائق والمفاهيم والقيم والمبادئ والقوانين والروؤى والأفكار التى تثكل خبرة الفرد بموضوع أو قضية ما فى فترة زمنية محددة ــ ـويعرفها الباحث إجرائياً في هذا البحث بأنها: هي إحدى جوانب الخبرة النظريـة والتطبيقية التي تتشكل

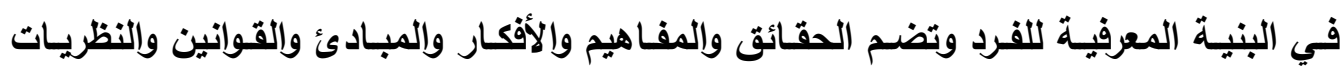

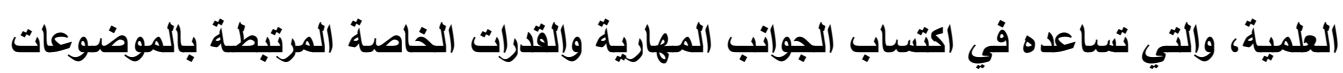

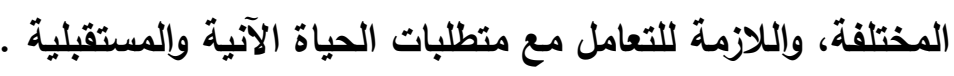




\section{ب- اقتصاد المعرفة: Knowledge economy :}

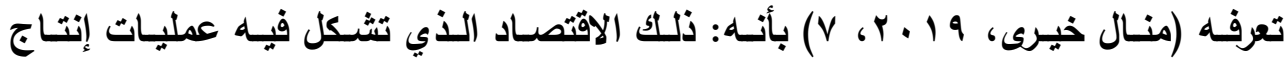
المعرفة وتوظيفها العامـل الرئيس فى العمليـة الإنتاجيـة والخدميـة، والمكون الأعظم للقيمـة المضافة للمجتمعات الاقتصادية الدولية التـى تعتمـ على التـوافر الموسـع لتكنولوجيـا المعلومـات والاتصـالات وشبكات الإنترنت فـى

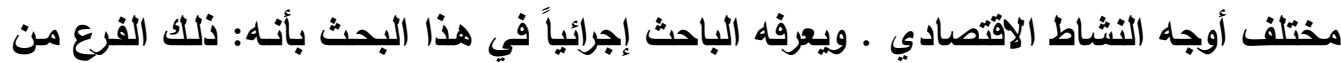
فروع علم الاقتصاد الذى تحقق فيه المعرفة الجانب الأعظم من القيمـة المضـافة، والذى يعتمد على استثمار وتوظيف تكنولوجيا المعلومات والاتصالات في مختلف أوجه النشاط الاقتصـادى،

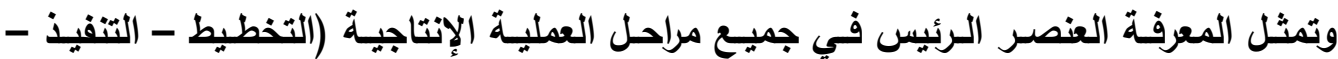

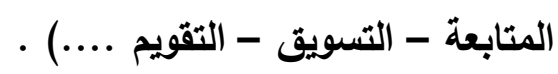

ع - المدرسة الثانوية الصناعية: Industrial secondary School هى المدرسة التى تستقبل طلابها بعد الانتهاء من مرحلة التعليم الأساسى، وتهدف إلى إلى إعداد العمالة الفنية الماهرة، المزودة بالمعارف والمهارات والقيم والاتجاهـات التى تساعدهم على التكيف مـ متطلبات سوق العمل ومسايرة التطور التكنولوجى السريع، للإسهام بوعى

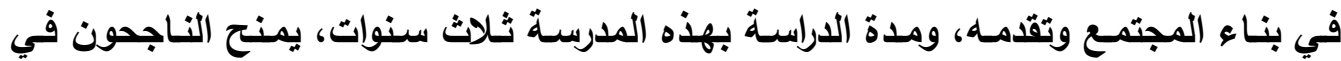
نهاية هذه المرحلة دبلوم المدارس الثانوية الصناعية في أحد التخصصات ـ (الجهاز المركزى

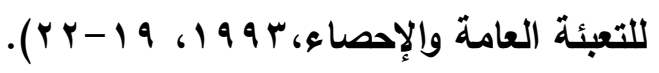

•- تخصص الزخرفة والإعلاز: Decoration and advertising specialty

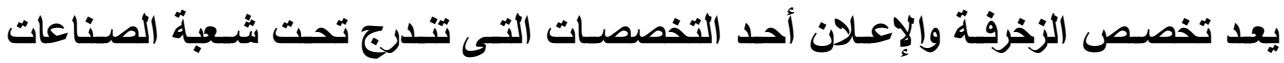
الزخرفية إحدى الشعب العشر التى تضمها المدرسة الثانوية الصناعية، ويعد من التخصصات الهامة والضرورية فى عصرنا الراهن وكل العصور، ويضم تخصص الزخرفة والإعلان أربعة

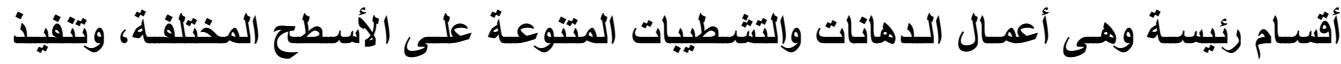
التطبيقات الزخرفية على أسطح متعددة، وتصميم وتتفيذ الإعلانات، ثم قواعد وأصول تنسيق المنازل والحدائق ونوافن العرض والديكورات السريعة . 
צ- منهج تخطيطوإدارة الإنتاج: Production planning and management

curriculum

تعددت تعريفات منهج تخطيط وإدارة الإنتاج، حيث عرف بأنها: "هو أحد المقررات الفنية التـي يدرسـها طـلاب الصـف الثالث الثانوي الصـناعي بهـف التعرف على كـل مـا يتعلق

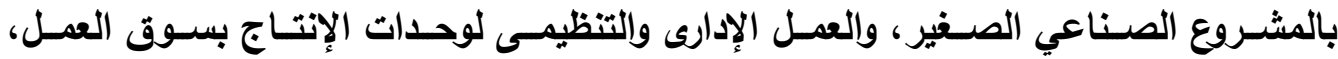

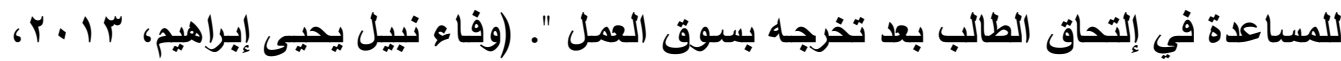

وعرف أيضـاً " بأنها العلم الذي يبحث فى دراسـة إنشـاء المشـروعات الصناعية وكيفيـة

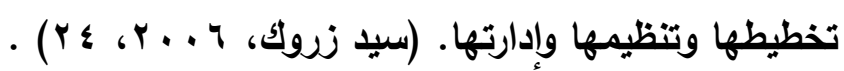

ويعرف منهج تخطيط وإدارة الإنتاج في هذا البحث بأنها: أحد المـواد الفنيـة في برنـامج

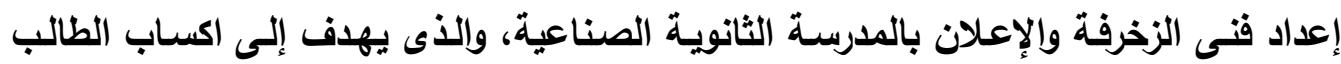

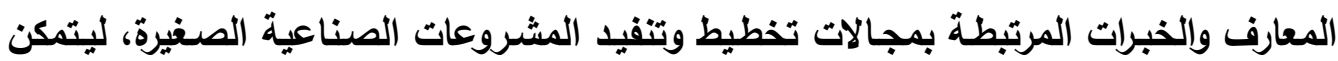
الخريج من ممارسـة هذه الخبرات والمهارات فح محيط العمل متبعاً الأسس العلمية لجودة الأداء.

\section{أولاً: الإطار النظرى للبحث:}

تناول الإطار النظرى للبحث المحاور التالية:

\section{المحور الأول: تطوير المناهج الدراسية: Curriculum development}

إن عملية تطوير المنـاهج الدراسية فى حد ذاتها لا تقل أهمية عن عملية بناء المناهج

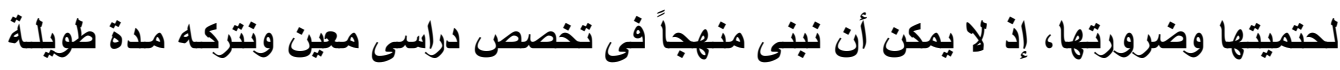
دون أن تناله يد التغيير والتطوير، وإذا ظل هذا المنهج على حالته فإنتا نحكم عليه بـالجمود والتخلف، ومن هنا تصبح عملية التطوير عملية حتمية لا غنى عنها وهى فى نفس الوقت

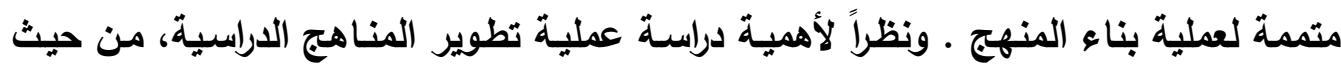

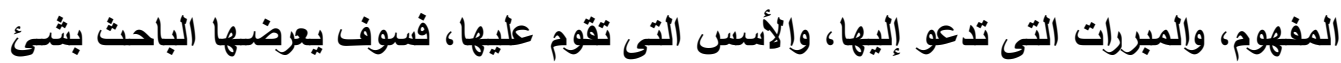

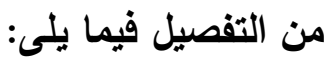




\section{أولاً : مفهوم تطوبر المنهجج:}

تثير الدراسات والأدبيات فى مجال المناهج (أحمد اللقانى، ه9 99 1، V I)، (حلمى الوكيل، محمد المفتى، ب 99 1، 9 ه) إلى عدة تعريفات لمفهوم تطوير المنهج ومنها: - إدخال تجديدات ومستحثثات في مجالها بقصد تحسين العملية التريوية ورفع مستواها، بحيث تؤدي في النهاية إلى تعديل سلوك الطلاب وتوجيهه في الاتجاهات المطلويـة، وفق

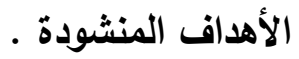

- كما يعني التغير الكيفي في أجزاء بعض أو جميع عناصر المنهج، الذي من المفترض أن يؤدي إلى رفع كفاءته من أجل تحقيق أهداف التطوير.

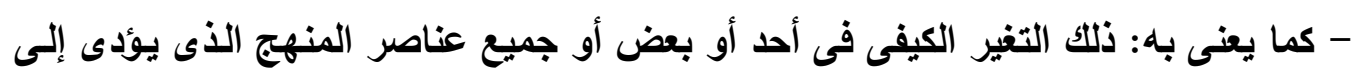

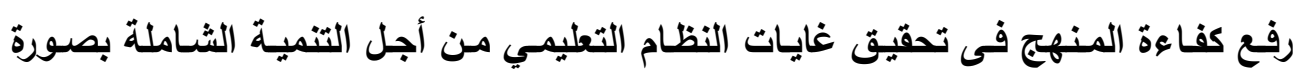
أفضل مما هو قائم حالياً . ويعرف تطوير المنهج في هذا البحث بأنها: إدخال تجديدات وتحديثات في جميع عناصره

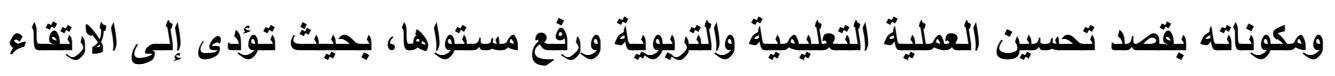

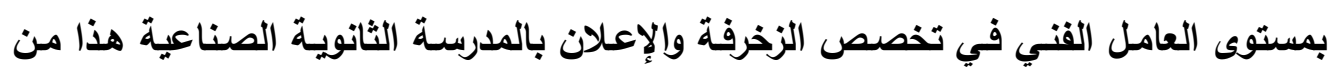

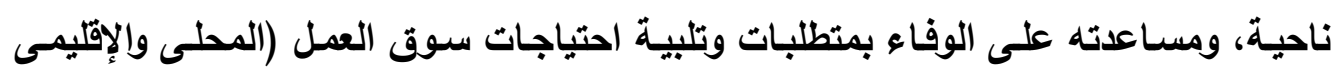

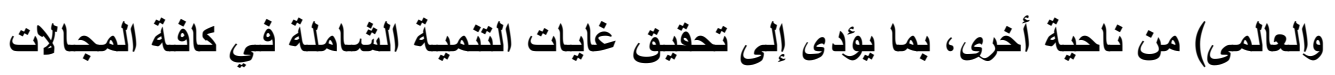

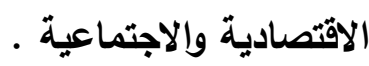
ثانياً : مبررات تطوير المنهج: تستند عملية التطوير إلى مجموعة من المبررات، (رشدى لبيب، فايز مراد، ب99 9 1، 0 ؛ )

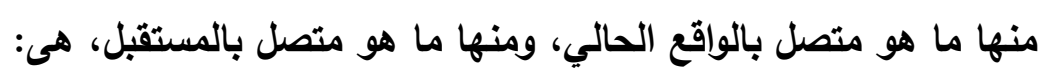

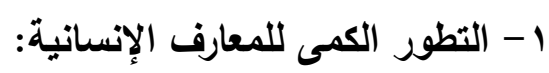
مـن أبرز ســات عالمنـا المعاصـر ذلك التطور الهائلـل والسـريع فـى المعـارف الإنسـانية

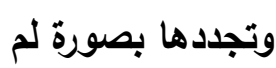
تعهدها البثرية مـن قبل، وهذا يعنى أن المعلومـات والمعارف لا تظل على حداثتها لوقت

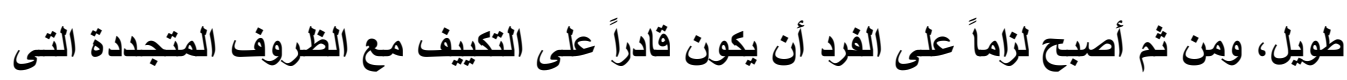
تحيط به، ومن هنا أصبح تقديم كم من المعلومـات للمتعلم على مدى سنوات دراسية متعددة 


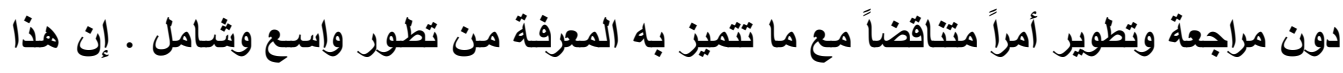

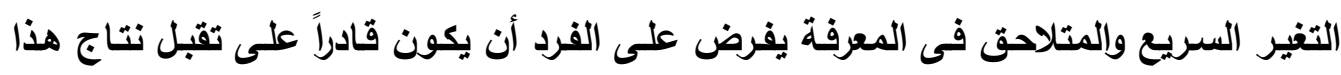

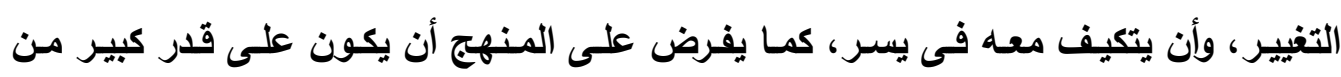

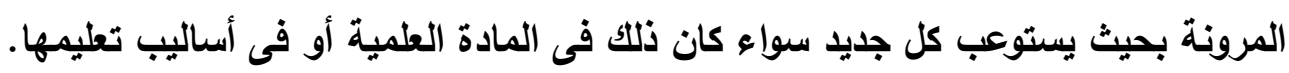
r- سيادة المنهج العلمى فى شتى مجالات الحياة:

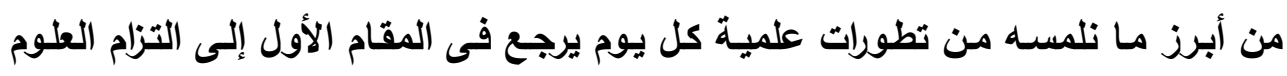

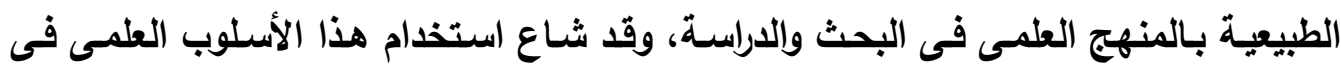

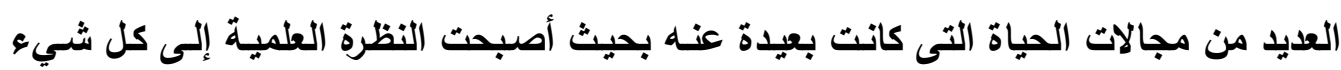

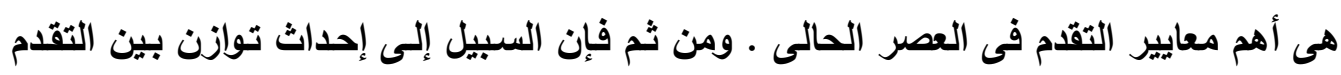

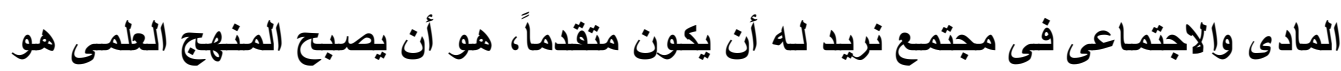

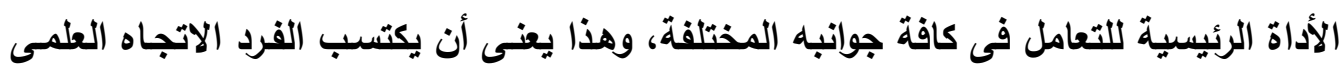
فى النظر والتفكر وإتأمل فى كل أمر وفى كل مشكلة من المشكلات الحياتية التى يمر بها لهابها

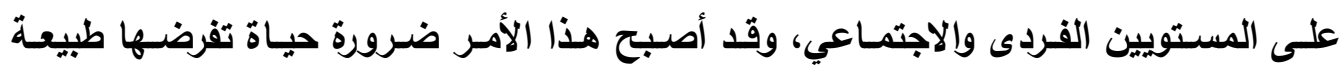

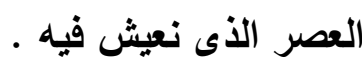
r- التلاحم بين العلم النظرى والتطبيقى:

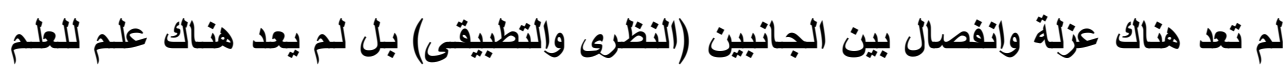

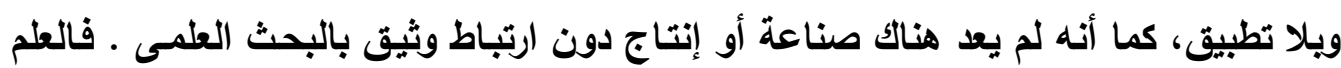

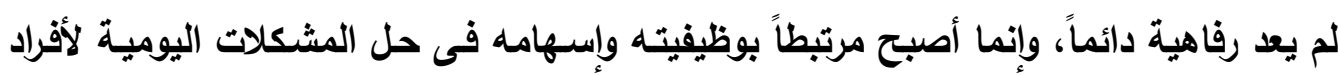

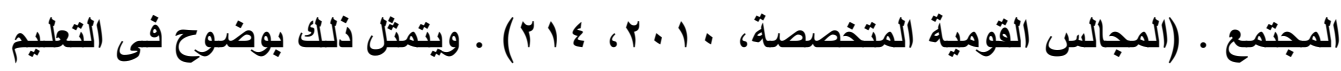

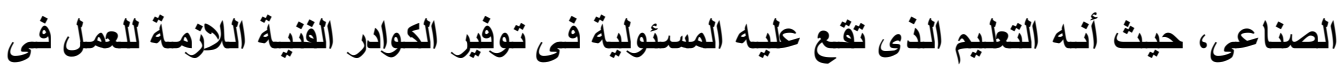

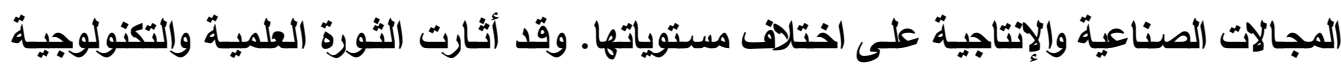

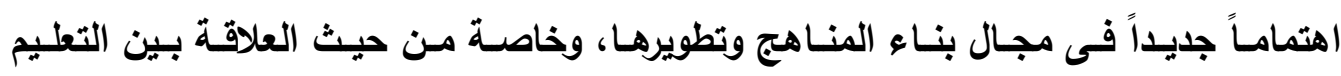

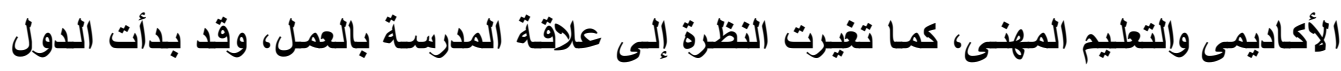

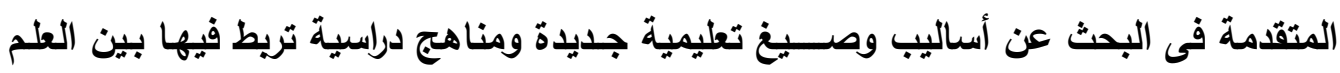

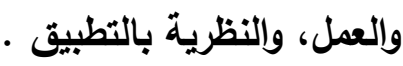
؛ - تززيد وسائل الاتصال بين الجماهير: 
لـم يعد مفهوم البيئة الإنسـانية يعنى ذلك الإطـار المكانى الذى يحيط بالإنسـان والذّى

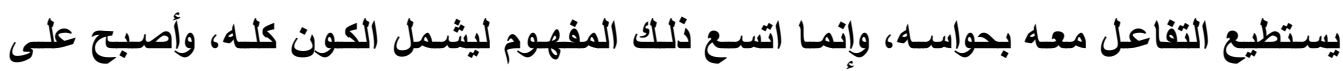
الإنسان العصرى أن يتفاعل مع بيئته بهذا المفهوم الجديد وآقاقها المتجددة ـ ذلك أن التطور

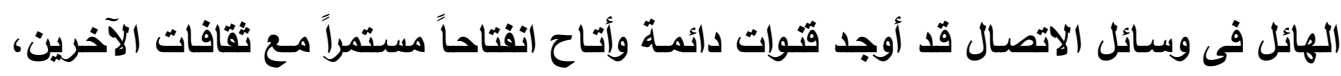

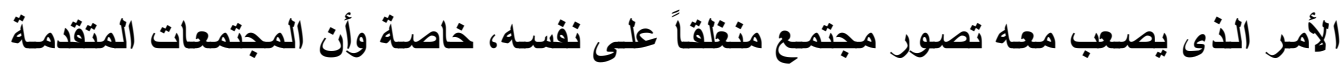

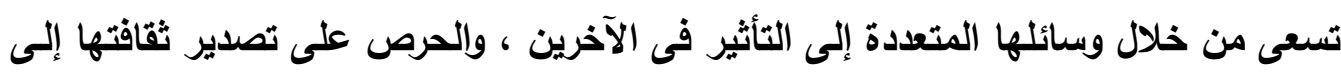

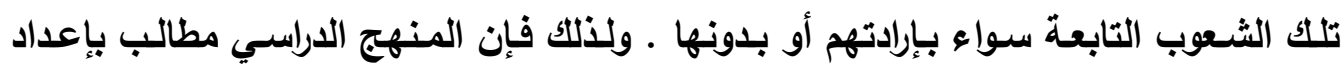
الفرد القادر على النظر فى تلكك الثقافات بفكر واع ومتفتح، وإبداء الرأي فيها ونقدها ويتبين جوانب التثـابه والاختلاف بينها ويسين ثقافته، ويختـار المناسب منهـا بمـا يتفق مـع قيمـه وثثقافته ودينه وعاداته وتقالياه .

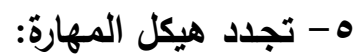
أدت الثورة العلمية والتكنولوجية المعاصرة إلى تجديد في هياكل المهارة، الأمر الذى هيأ

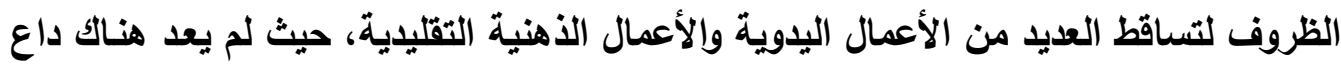

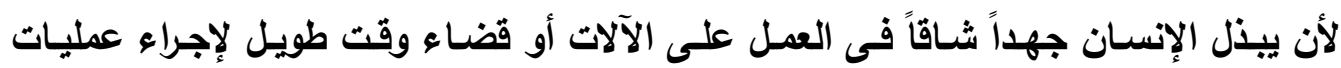

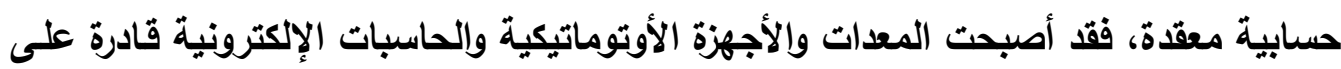

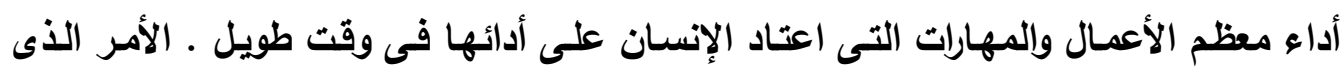

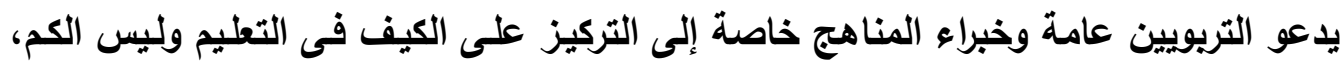

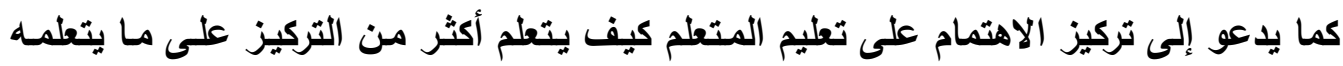

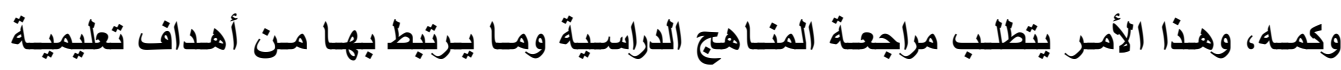

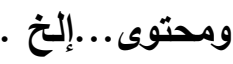
צ - الأخذ بمفهوم التربية المستمرة: يعتبر مفهوم التربية المستمرة من أبرز المفاهيم التى دخلت حديثاً إلى ميدان التربية،

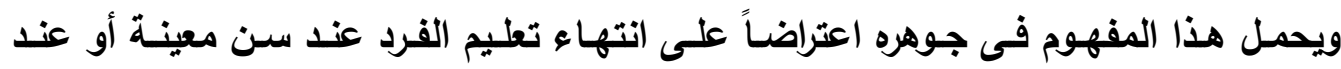
مستوى تعليمى محدد، ويؤكد على استمرار تعلم الفرد طوال حياته، ومن ثم لـم تعد المدرسـة مهنة

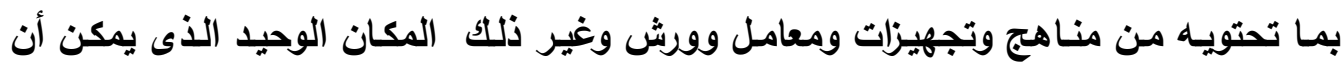
يمارس التعليم فيه، بل هناك هيئات ومؤسسات وأجهزة أخرى غيرها تستطيع أن تثـارك فى ومئ 
هذا الـدور الاجتمـاعى الهام ـ مـن هنـا أصبح مـن الضـرورى أن تخضـع المنـاهج للمراجعة

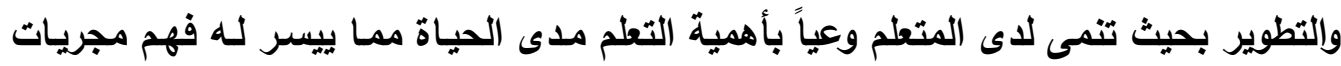

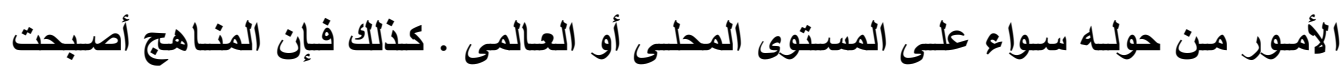

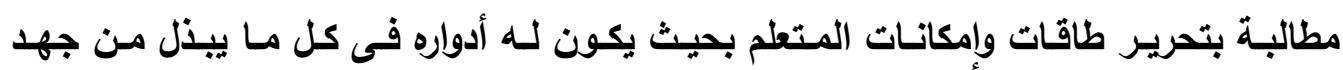

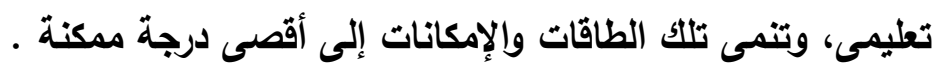
V - تزايد التجديدات التريوية: وقد شمل التجديد أهداف ووظائف المؤسسـات التعليمية وأسـاليب التنظيم والإدارة والأدوار والعلاقات السـائدة بينها، والمنـاهج مـن حيث الأهداف والمحتوى وطرق التدريس والوسيائل

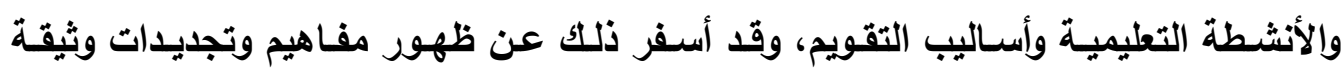

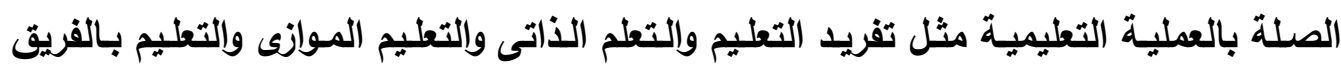
والتعليم المبرمج والتعليم بالمراسلة والتعليم الإكتروني، وكلها صيغ جليدة تدور حول تركيز

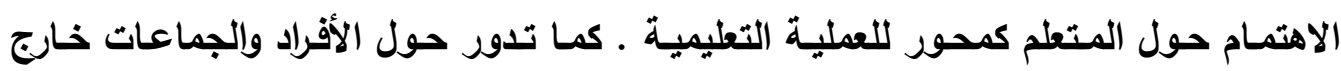
النظام التعليمى ومدى مشاركتهم فى عملية التجديد، مثل نقابات المعلمين وغيرها.

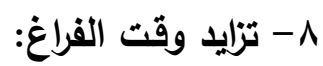
يمر العالم بثورة هائلة فى مجال الوسائط الإكترونية، ولقد أدى ذلك إلى تخفيض سـاعات العمل اليومية، الأمر الذى سيترتب عليه زيادة كبيرة فى وقت الفراغ، ويتطلب ذلتك من التربية

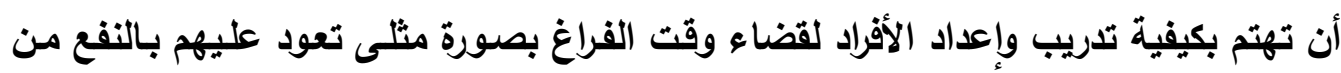

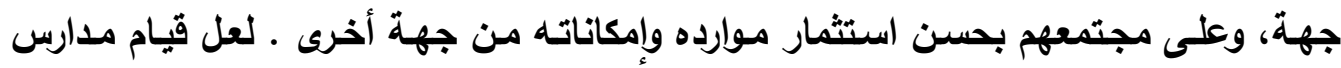

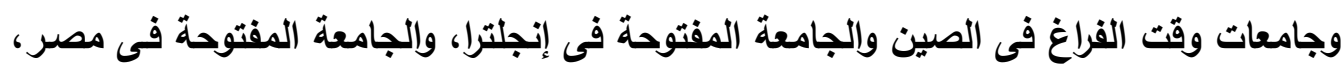
والتعليم الإلكتروني، ونشر الدراسـة بالمراسلة والبث التليفزيوني فى إيطاليا والسويد واستراليا

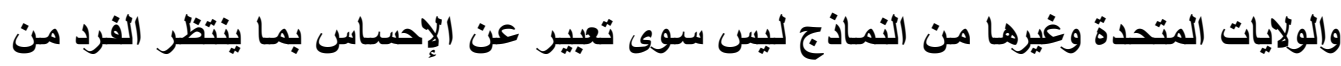
تحديات ينبغي إعداده لمواجهتها من الآن . 9- التشكك فيما درج عليه التعليم: أسـفر التقدم العلمسى وإلتسـارع التكنولـوجى الذـى يشـهـده العـالم عن سـوط العديــ مـن الحقائق والمسلمات التى كانت تتضمنها المناهج الدراسية إلى عهـ قريب ـ ولقد أفرز التفجر

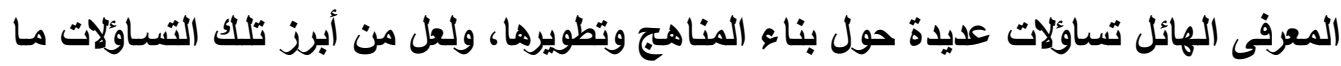


أثير حول جدوى الحقائق والمعـارف المتنـاثرة والتى تحتويها المنـاهج وعلاقتها بـالتغير فى في الأداء فى الاتجاه المطلوب، وما أثثر حول مدى تنوع المناهج بحيث تواجه الأهداف المختلفة

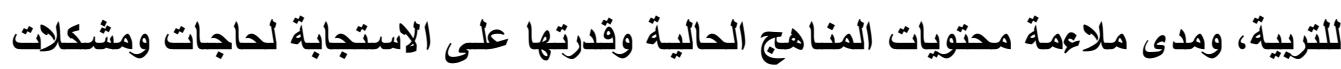
المتعلمين، والمشكلات البيئية والاجتماعية فى نفس الوقت، ومدىى القدرة على تغيير النظرة

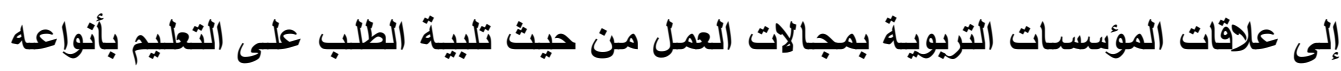

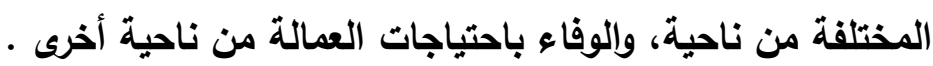

\section{ثالثثاً: اتجاهات تطوير المناهج:}

حددت الدراسـات والأدبيات مجموعة من الاتجاهـات التى تفرض نفسـها ونؤكد عليها فى إطسار الحديث عن تطوير المنـاهج (رشدى لبيب، فايز مـراد، ب999 19، جه)، (أحمد حسين

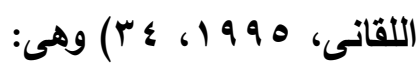
1- التطلع إلى حياة أفضل:

حيث سـاد اتجـاه قوى للدى الدول المتقدمـة وإلناميـة على السـواء أن السبيل الصـيح

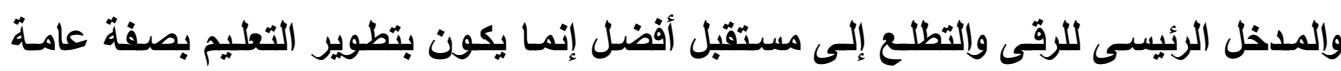

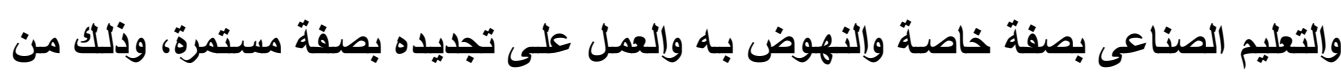
خلال مراجعة وتظوير المنـاهج الدراسية باعتبارها وسيلة التربية فى إعداد الثباب وتزويدهم

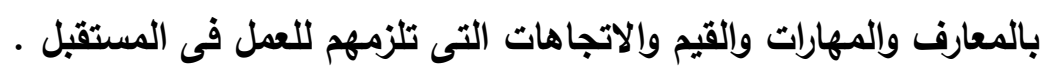
r - قدرة التربية على المشاركة فى إحداث التنمية: تقوم التربية بدور هام وفاعل فى إحداث التنمية والتغيير المنشود داخل المجتمع، وذلك فيك

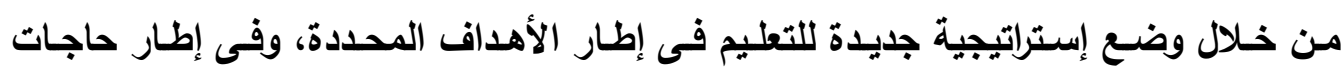

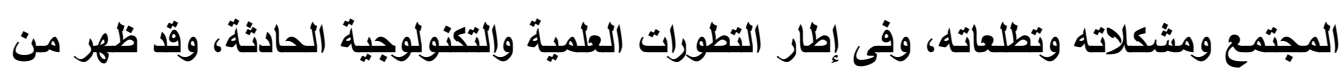

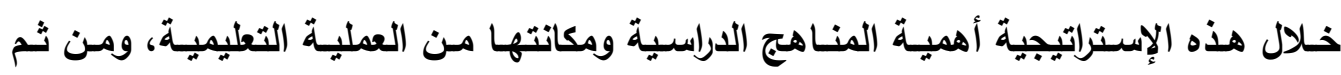
ضرورة مراجعتها والعمل على تطويرها بما يناسب تلك المتفيرات . r- أهمية التخطيط السليم فى تطوير المنهج: حيث تتطلب عملية تطوير المنهج وفق الأسلوب العلمى السليم الاهتمام بعملية التخطيط، ويعنى ذلك إعمال الفكر في كيفية إحداث التطوير النوعى وليس مجرد الاهتمـام بـالتطور 
الكمى، ويتضمن ذلك اعتبار العلم وما يشمله من عمليات (التحليل والتفسير والتجريب ..) ، بالإضافة إلى الموضوعية فى مختلف هذه العمليات هو الأساس الضروري فى تطوير المنهج. ؟ - تظوير المنهج من أهم مجالات التجديد فى التربية:

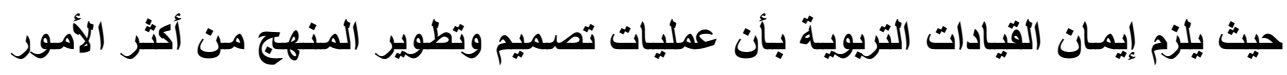
أهمية فى مجالات التجديد التربوى، باعتبار أن المنهج هو وسيلة التربية في إعداد الأفراد

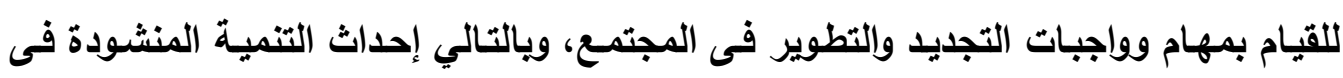

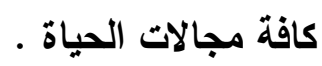
ه - الخبرات العالمية وعملية تطوير المنهج:

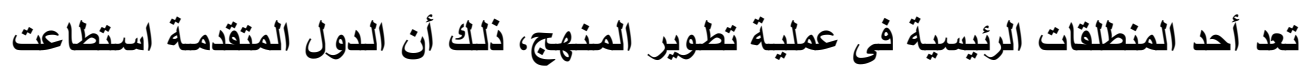
أن تحرز تقدماً كبيراً فى مختلف النواحى العلمية والتكنولوجية، ومن غير المقبول فى ظل هذئ هذان

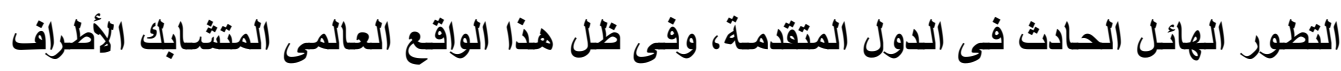

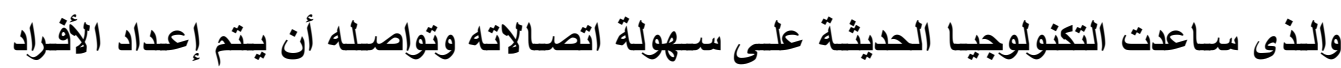

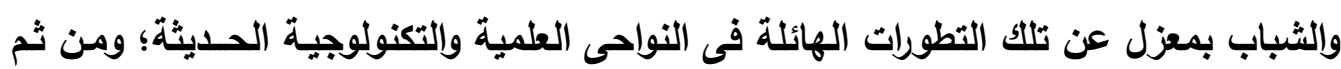

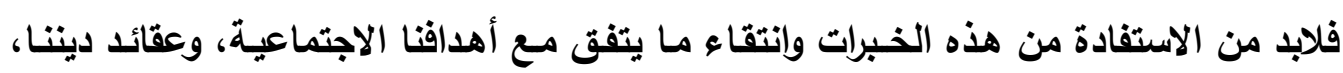

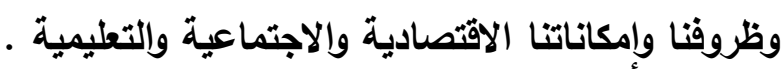

رابعاً: أسسس التطوير:

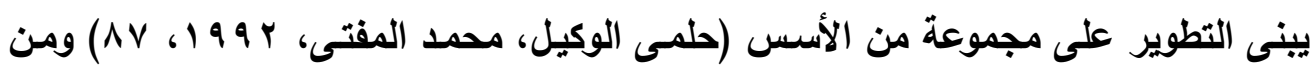
أهمها ما يلي: ا- التخطيط: فالتطوير الناجح مثله مثل أيـة عملية يقوم بها الفرد أو الجماعة فهو الذي

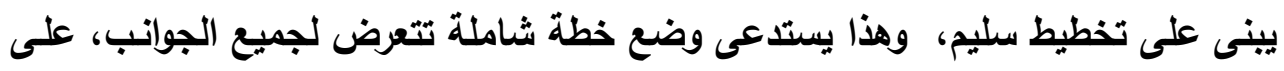

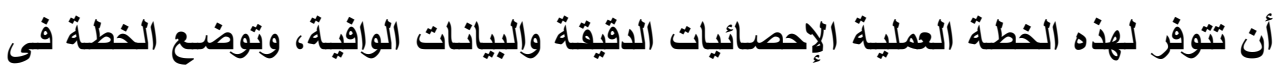

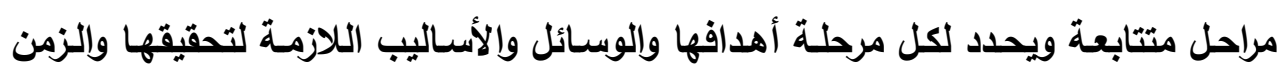

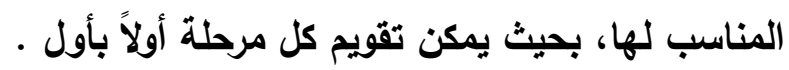

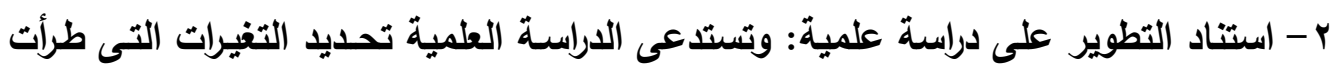
على ميول المتعلم وقدراتهـه وحاجاتـه، ونموه والعوامـل المؤئرة فيه، وكذلك دراسـة العوامل

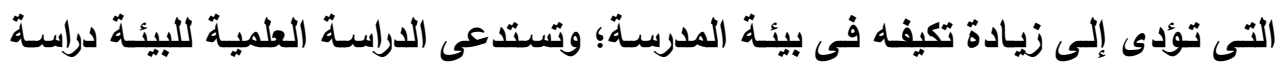


مصادرها المختلفة وطرق استغلالها والتغيرات المنتظر حـوثها، بحـــيث يعدل المنــهج

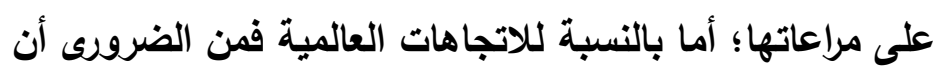

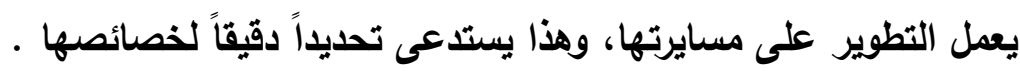

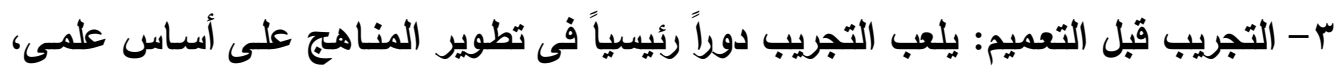
وقد اتسعت مجالات التجريب فأصبحت تشمل كل جواتب العملية التعليمية، ويتم التجريب على عينـة مـن الطلاب أو المعلمين أو الكتب، ومـن الضـرورى أن تكون العينـة ممثلــة تمثيلاً صادقاً، وأثناء التجريب تظهر مجموعة من المشكلات التى تستدعى إيجاد الحلول المناسبة لها وهذا يتطلب إعادة التجريب عدة مرات حتى يتم التوصل إلى نتائج ثابتة .

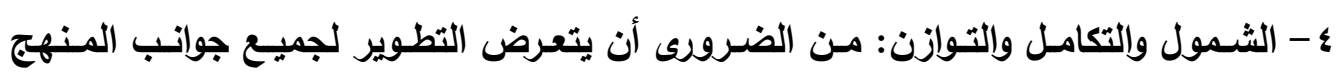
ويالتالى يجب أن يكون التطوير شاملاً، كما يجب أن يكون متكاملاً، وذلك لأن كل جانب

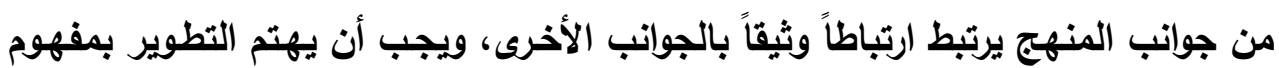
التوازن، ويتطلب ذلك تحديد الوزن النسبى لكل عامل أو جانب وفقاً لقرتهه ومساهمته فى تحقيق الهذف ووفقاً للاور الذى يمكنه القيام به . ه- التعاون: ويعنـي ذلك أن يثترك في التطوير كل مـن لـه صلـة مباشـرة أو غير مباشـرة

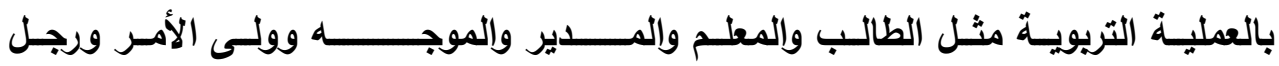

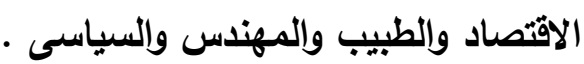
צ- الاستمرارية: فالتطوير لا ينتهي أبداً إلا أنه يتم فى صورة عمليات لكل عملية منها بداية ونهاية ـ ومن الأصلح أن تفصل بين عملية التطوير التى تتم وعملية التطوير التى تليها مدة زمنيـة لا تقل عن (ه سنوات) حتى يعطى للمنهج المطور فرصة للاستقرار تسمح

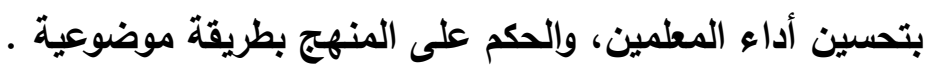

خامساً: ملاخل تطوير المنهج:

لتطوير المنهج مداخل متعددة (حلمى الوكيل، محمد المفتى، ب 99 1 1، V^)، (رشدى لبيب،

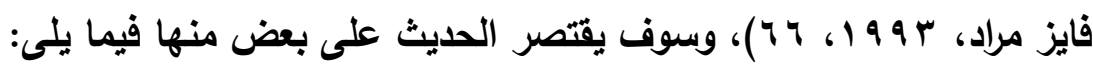
1 - تكنولوجيا التعليم مدخل لتطوير المناهج: ويقصد بمصطلح التكنولوجيـا هو تطبيقات أسس أو مبـادئ ونظريـات علمية في واقـع

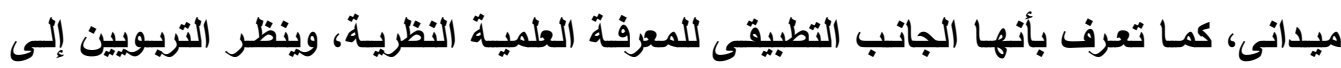


عملية التربية باعتبارها وسيلة التعامل مع الإنسان كصانع للتنمية والتقددم، ولا شكك أن محور

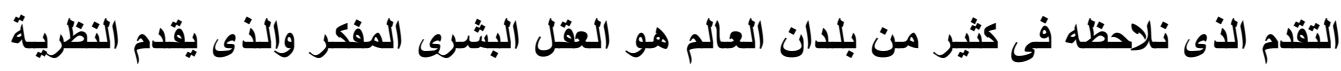

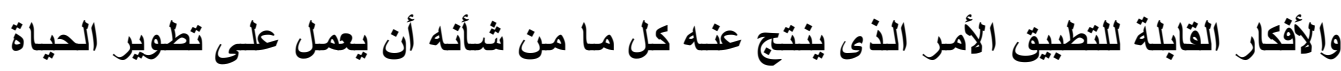
اليومية للناس، وكما استخدمت التكنولوجيا فى أثكال متعددة فى الحياة، فقد استخدمت أيضاً

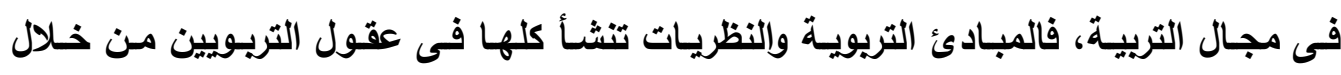
خبراتهم ودراساتهم وتصوراتهم وإدراكهم لحركة تطور الفكر التربوى عبر العصور، ومن خلاديال

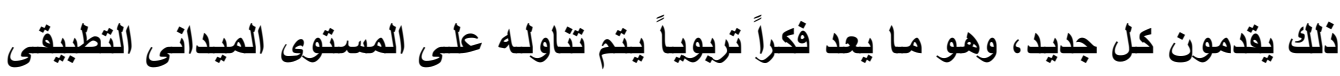

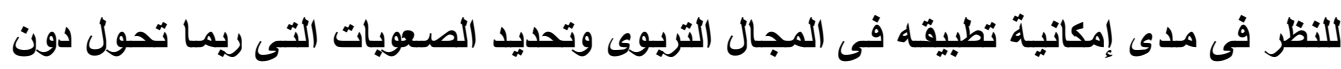

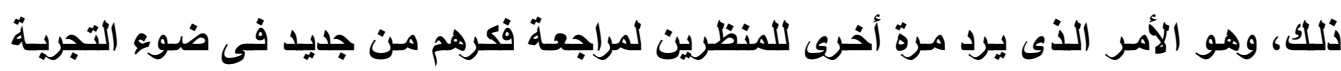

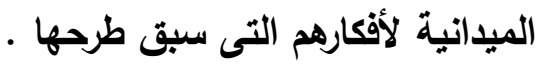
وعلى ضوء مـا سبق وفى إطار مفهوم التكنولوجيا وتطبيقاتها فى مجال التربيـة يمكن

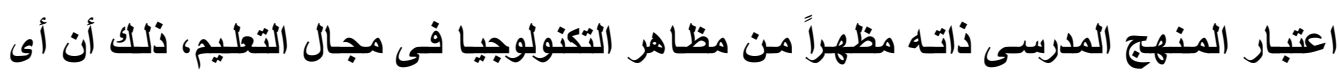

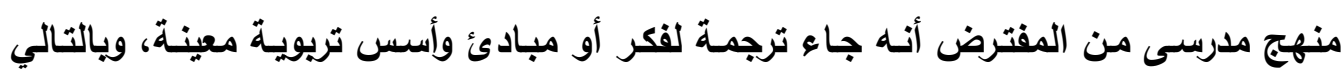
فهو تطبيق لفكر ما، ومن ثم فإن خبراء المناهج والمتخصصين فيها يعتبرون المنهج مظهراً

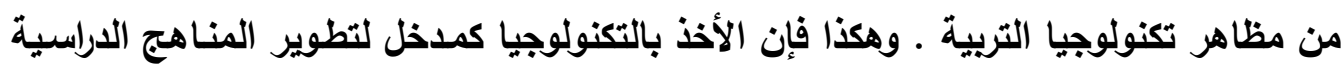

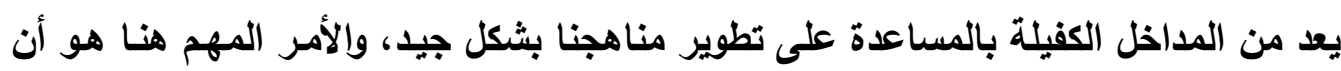

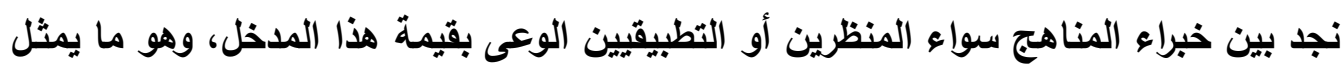
الضمان للالتزام به فى عمليات تخطيط المنهج وتنفيذه وتقويمه .

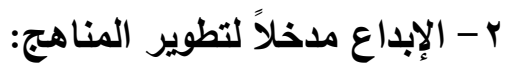
يمكن لمخططي ومنفذي المناهج أن يتبنوا هذا العمل التطويري بحيث يكون الإبداع هو

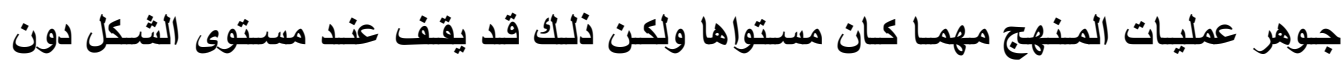

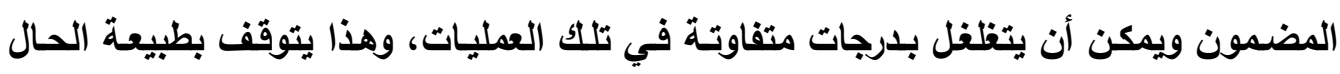

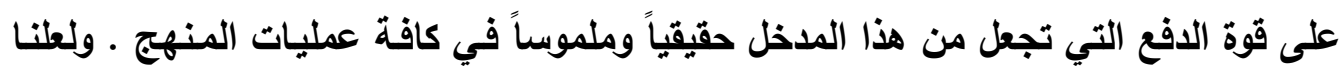

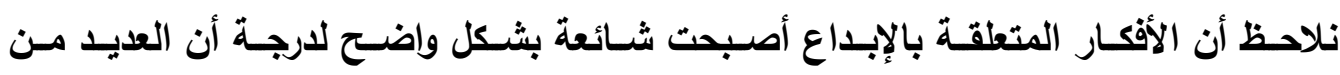

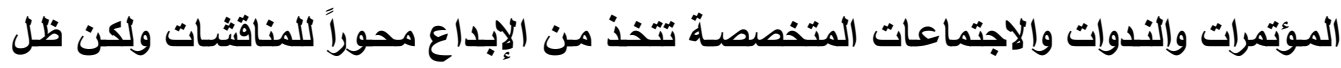
ذلك على مستوي المفاهيم والمبادئ التي يقوم عليها بقصد التعيق والتأصيل . ل. 
وعلي الرغم من أهمية هذه المرحلة إلا أنها لا تعد كافية، كمـا أنها لا تعد ضماناً لتشبع

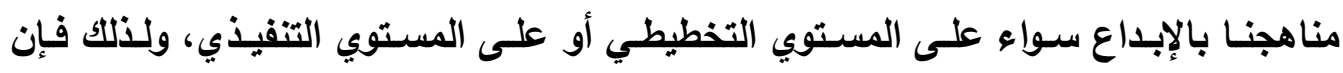

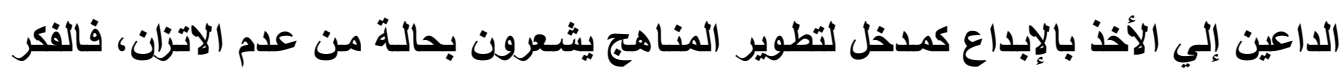

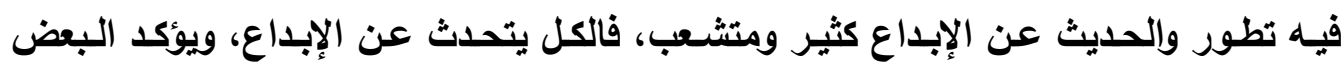

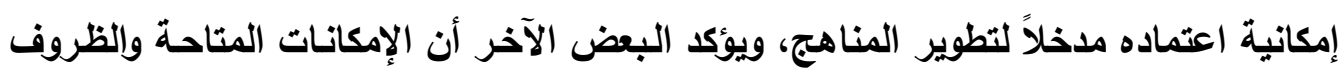

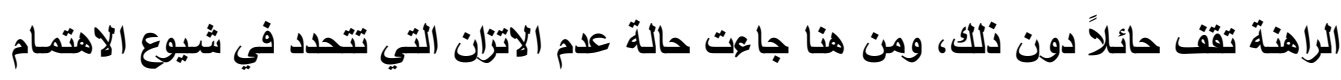
بالفكرة دون معرفة كيفية ترجمتها إلي واقع في عمليات المنهج ـ ماتهن

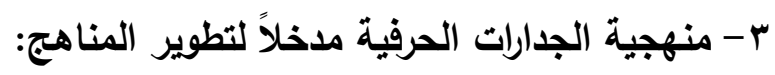
لإعداد العامل الفنى بالمدارس الثانوية الفنية الصناعية وفق منهجية الجدارات الحرفيـة، يتم

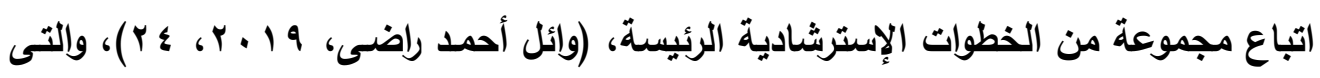
يمكن تحديدها فى التالى:

1- يـتم تقسيم كـل تخصـص نـوعى كتخصصـات (السـيارات، التبريـــ والتكييـف، النجـارة،

$$
\text { الزخرفة..إلخ)، }
$$

لمجموعة حرف فرعية بحيث تمثل كل حرفة مستوى مستقل بذاته .

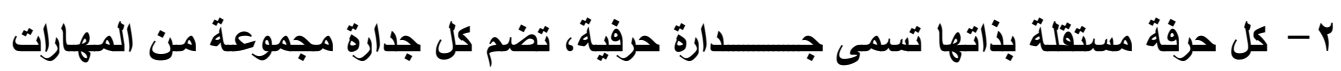

$$
\text { الرئيسة والفرعية }
$$

القائمـة على مجموعة كبيرة من المعارف والقيم المترابطة والمتكاملةة، وتحقق فى ذات الوقت متطلبات سوق العمل، على أن يتم رفع احتياجات سوق العمل وما به من تطورات

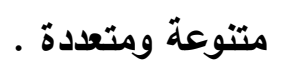

ب- يـتم ترتيـب الجـارات بأسـلوب علمـى ومنطقى - بـالرجوع للخبـراء - وفـق مسـتويات

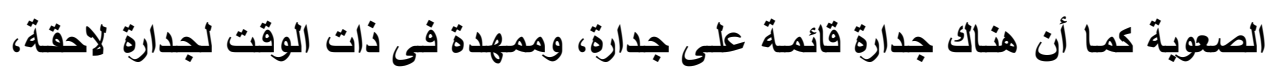

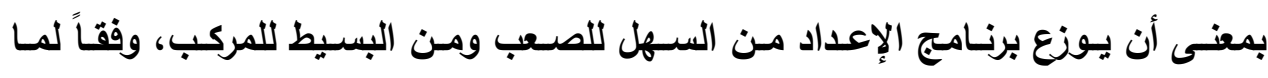
تتضـمنه كل جدارة مـن مهارات ومـا تتطلبه مـن عمليـات تعليم وتـدريب، بحيث ينتقل

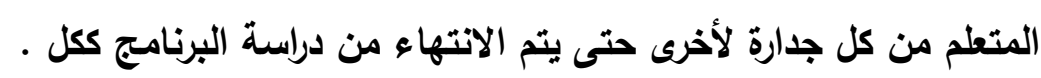

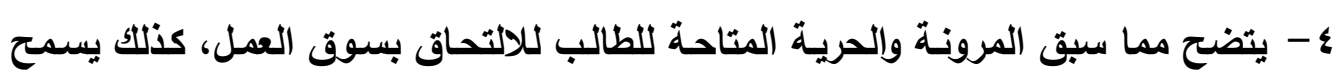

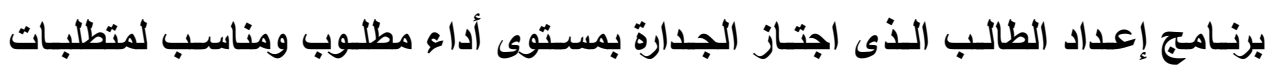


احتياجـات سوق العمل، أن يحصل على رخصـة لمزاولـة الحرفة المتعلقة بالجدارة التي

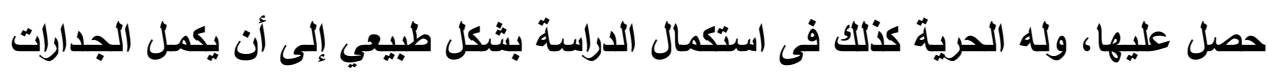

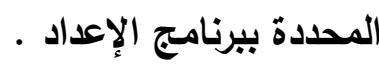

\section{سادساً: أطرونماذج لتخطبطوبناء المناهج:}

يتضـمن التخطيط سلسـلة من القرارات يتخذها المخطط من خـلال متغيرات مختلفة مـن

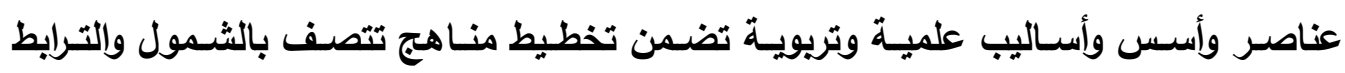

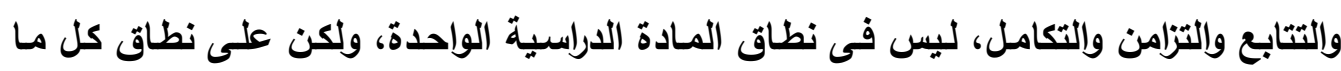

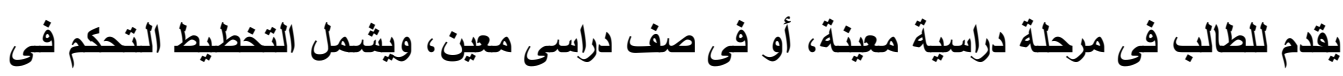

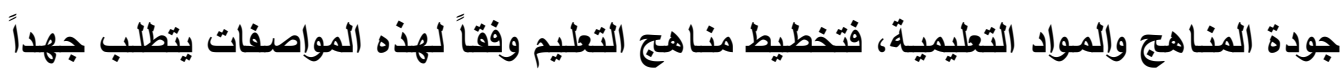

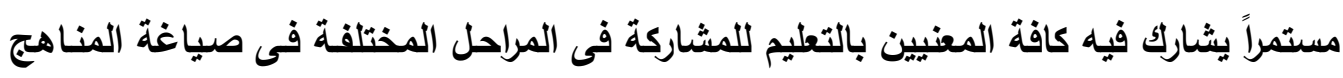

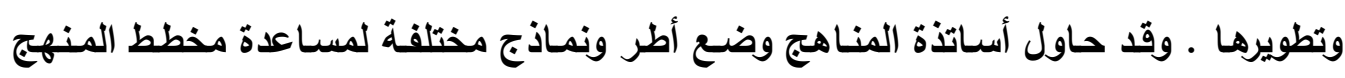
على أن يحقق هذه الأهداف، وقد تم اختيار بعض أطر تخطيط المنـاهج بما يناسب مناهج

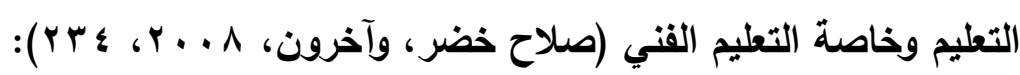
1 - 1 - نموذج كوثر كوجك :

يعد هذا النموذج شاملاً لمكونات وعناصر وأجزاء المنهج كنظام، حيث يعتبر المنهج كله

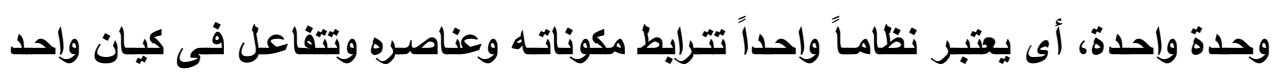
ويتصمن: أ. منطلقات المنهج: (فلسفة المجتمع وأيدولوجياته - طبيعة وفلسفة المادة الدراسية -

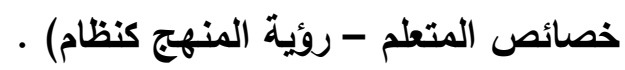
ب. فلسفة المنهج :(القلسفة التقليدية - التقدمية - التجديدية - إعادة البناء) . ت. الأهداف العامة للمرحلة التعليمية .

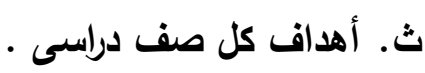
ج. المحتوى: (المفاهيم والمدركات - التعميمات) . ح. الأنثطة التعليمية .

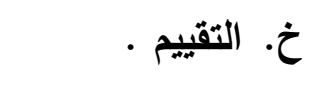
د. التغذية الراجعة . . . 
أ. البدء بالفكر التربوى (نظريات المنهج) كموجه لكافة عمليات المنهج .

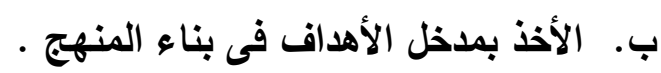

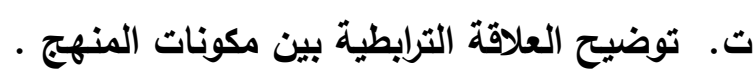

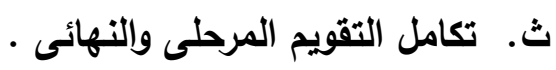

ج. شمول التقويم (تحصيل الطلاب - فعالية المنهج - أداء المعلم) .

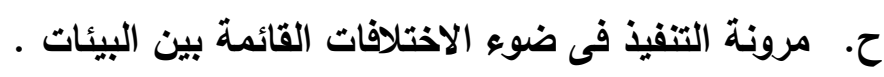

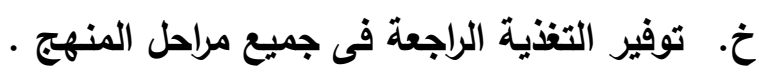

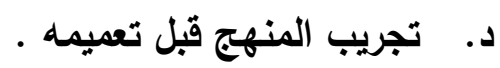

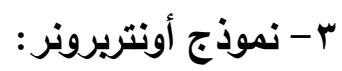

يعد هذا النموذج شاملاً فهو يراعى متطلبات المجتمع والخدمات ومتطلبات المهنة، ويؤكد

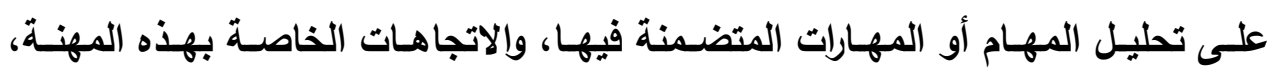

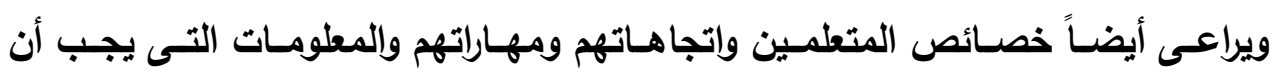
يتزودوا بها، ومن خلال هذه الخصائص والاتجاهـات والمعلومـات والمهارات تحدد أهداف التعليم التى من خلالها تحدد استراتيجيات البرنامج، ثم ينتقل النموذج انتهات انتقالاً منطقياً إلى تطبيق البرنـامج، ويهتم أيضـاً بالتغذيـة الراجعة مرحلياً ونهائياً، ويراعى استخدام التقيتيم

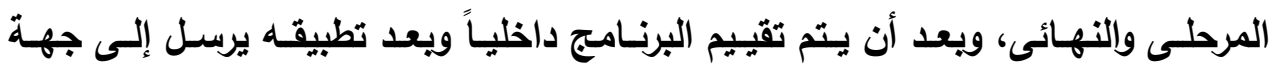

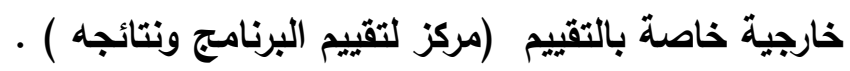
ع - نموذج المصانع الملكية البريطانية:

يحدد هذا النمـوذج خطوات بنـاء المنـاهج لمهنـة محددة أو عمل محدد، حيث يتــاول المخططون دراسة العمل المطلوب من الخريجين، ثم يتم التخطيط لإعداد الخريج القادر

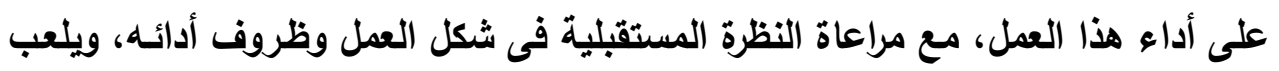
تحليل العمل دوراً أساسياً فى هذا النموذج، ويحدد النموذج خطوات بنـاء البرنـامج كمـا فئاء يلى 
العملـ - تحليـل العمـل - توصـيف العمـل - أهـاف التـريب ( البرنـامج ) - محتـوى البرنـامج - طرق التـريب - محتوى المقررات الدراسـية - إجـازة البرنـامج - التغذيـة الراجعة . ه - نموذج الاتحاد العربى للتعليم التقتى: يعد هذا النموذج شاملاً ، فهو يرى عملية بناء مناهج التعليم الفتى عملية معتمدة معقدة

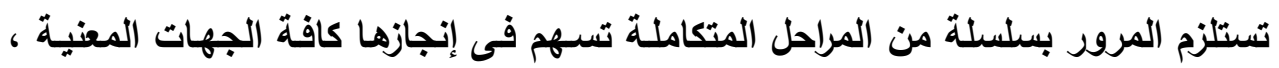
وفقاً لمفهوم ( التخطيط المفتوح ) ، ويصورة عامـة يمكن تقسيم مراحل بنـاء المنـاهج

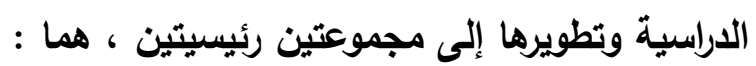

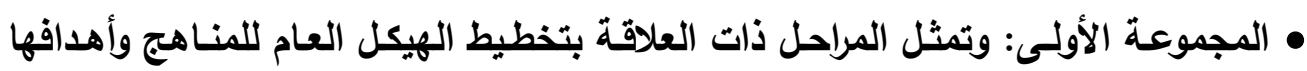

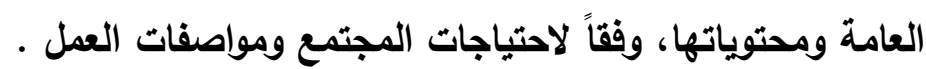
• المجموعة الثانية: وتثمل مراحل إعداد تفاصيل المناهج وتتفيذها وتقويمها، ويتم إنجازها

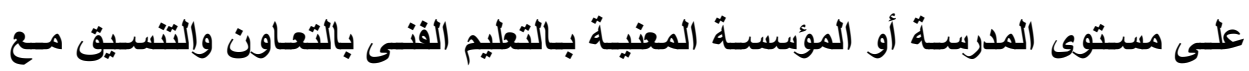

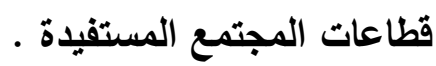
• ويتم هذا النموذج وفق الخطوات التالية:

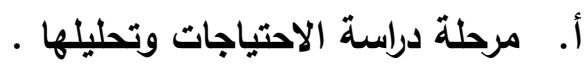
ب. مرحلة تحديد مواصفات العمل ومتطلباته . ت. مرحلة تحديد الهيكل العام للتخصصات والمحتويات . ث. مرحلة تحديد الأهداف وأساليب التقييم .

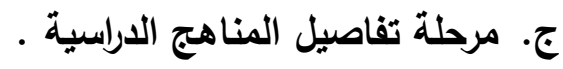

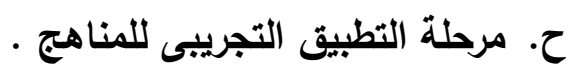
خ. مرحلة التتفيذ . ملة الطين

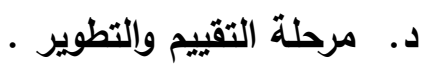


تبنى الباحث نموذج كوثز كوجك لتخطيط ويناء المنهج المقترح لطلاب تخصص الزخرفة والإعلان بالمدرسـة الثانويـة الصناعية نظراً لشموله وتضمنه لما يريد تحقيقه حيث يتضمن: منطلقات المنهج: (فلسفة المجتمع وأيدولوجياته - طبيعة وفلسفة المادة الدراسية خصـائص المـتعلم - روئيـة المــهـج كنظـام - فلسـفة المـنهج - الأهـاف العامـة للمرحلـة التعليميـة - أهداف كل صف دراسـى - المحتوى - الأنثطة التعليمية - التقييم - التغذيـة الراجعة ـ وهو ما سوف يراعيه الباحث في إعداده للمنهج المطور المقترح . كما يتضح مما سبق أيضاً أهمية وضرورة عمليات التطوير لكافة جواتب ومكونـات العملية

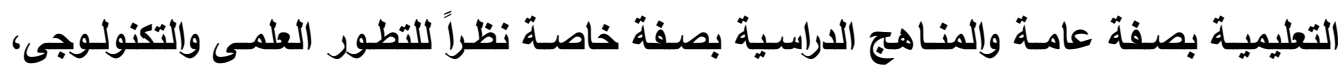
والحاجة الماسة لتحقيق التكامل بين الجواتب النظريـة والتطبيقية، واستثمار وقت المتعلم في تطوير ذاتـه وفى تطوير المجتمع من حوله، والتطلع إلى مستقبل أفضل إنما يكون بتطوير التعليم الصناعى والنهوض بـه والعمل على تحسينه بصفة مستمرة، وذلك من خـلال تطوير

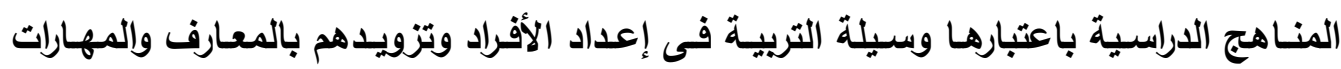

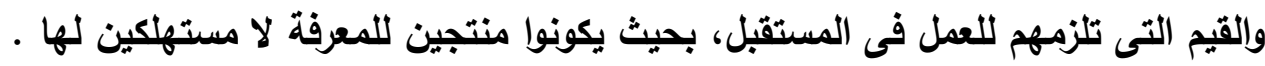

\section{Knowledge economy المحور الثانى: اقتصاد المعرفة:}

-

رغم شيوع المعرفة وإنتشـارها عبر الأزمنـة وإلقرون المختلفة، وإدراك أهميتها، وتوظيفها

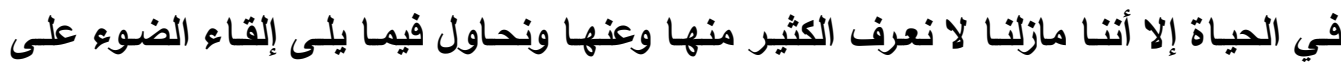
ماهيـة المعرفة، وخصائصسها الاقتصـادية وأهميتها، كذلك اقتصـاد المعرفـة وركـائزه، العوامـل والقوى الدافعة له وخصائصه.. وللمعرفة العديد من الرؤى والاتجاهات لثرحها وتفسيرها وذلك ولك

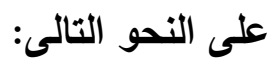
- فقد عــرف قاموس اكسفورد المعــفة بأنها:" درايـة مكتسبة بواســــة الخــبرة، وهـى ما يتاح للإنسـان من معلومات، إضافة إلى الفهم النظري والتطبيقي لهذه المعلومات". ويركز هذا التعريف على أهمية الخبرة 
فى تثكيل المعرفة، كذلك أهمية الجانب التطبيقي لتلك الخبرة وهذه المعلومات من أجل

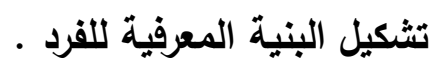

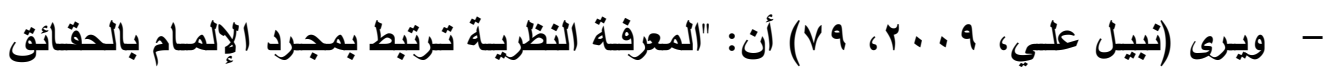

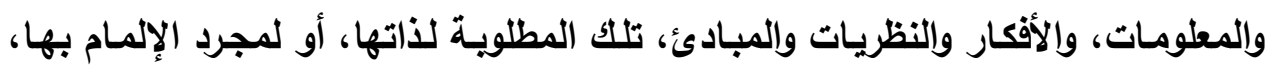

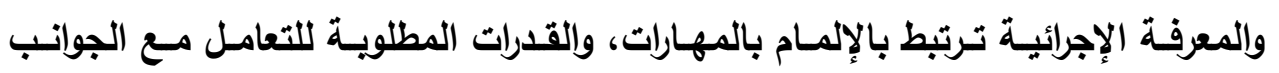

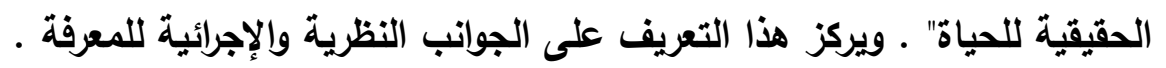

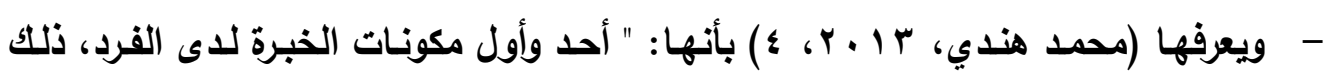
المكون الذي يضم الحقائق، والأفكار، والمبادئ، والقوانين، والنظريات العلميةة" ـ ويركز

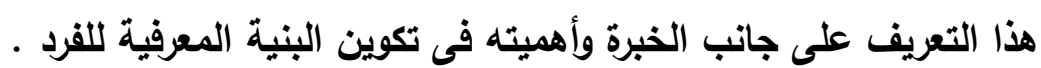

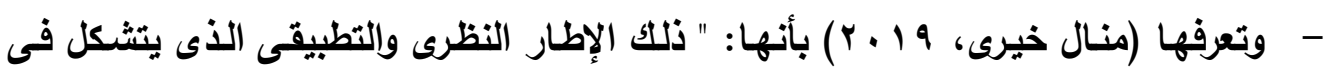

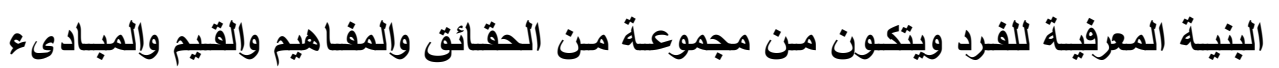

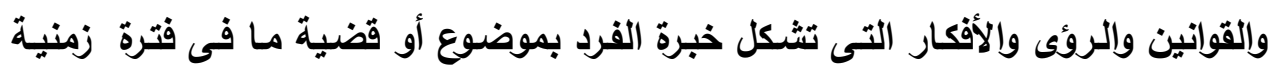

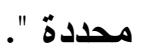
- ميعرفها الباحث إجرائياً في هذا البحث بأنها: هي إحدى جواتب الخبرة النظريـة والتطبيقية

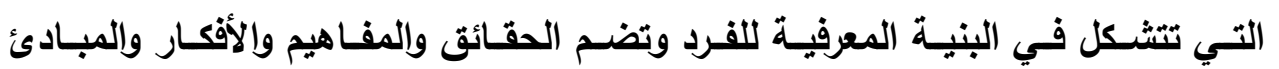

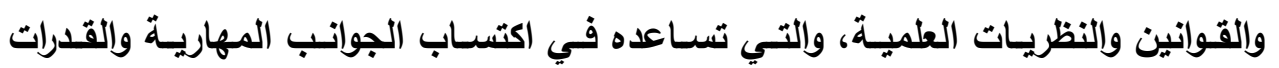
الخاصـة المرتبطة بالموضوعات المختلفة، وإللازمـة للتعامـل مـع متطلبـات الحياة الآنية

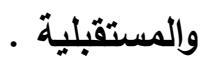
r - المعرفة خصائصها الاقتصادية:

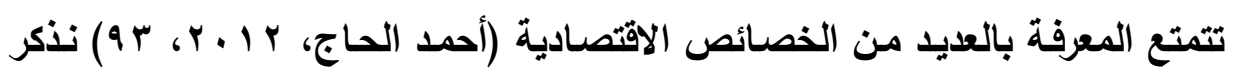
منها: أ- قرتها الهائلة على إعادة التشكل فى صورة قوائم، رسوم، أشكال، إحصائيات، وغيرها ب- قابليتها للانتقال بعدة أساليب عبر الانتقال الموجه، وقدرة العديد من القطاعات على الاستفادة منها. 
ت - قابليتها للمشاركة بين عدد كبير من المستخدمين والثركات ومنـاطق التجارة والدول

ث - تمثل الأعمدة الرئيسة للتنمية الاقتصادية والصناعية والاجتماعية والتريوية والثقافية

ج- تحولها إلى مورد اقتصادى وسلعة قابلة للتسويق والتوزيع بعوائد متزايدة باستمرار .

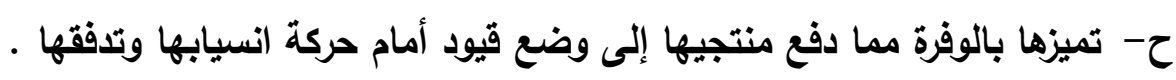

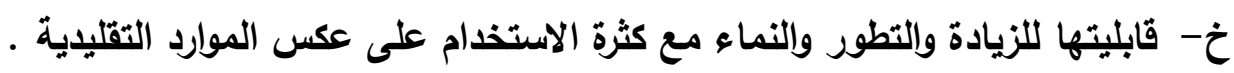
دـ تزايد قيمتها بزيادة مستوى دقتها وتكاملها مع معلومات أخرى .

\section{r- ب المعرفة وأهميتها الاقتصادية:}

تحتل المعرفة أهمية كبرى فى اقتصاديات عالم اليوم (أحمد الحاج، ؛ 1 . ب، . . 1 )، (أمير

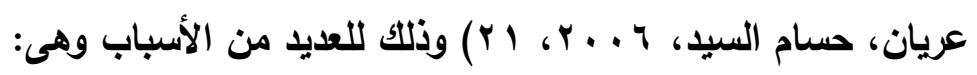
أ- تولد أنشطة جديدة مرتكزة على تبادل المعرفة .

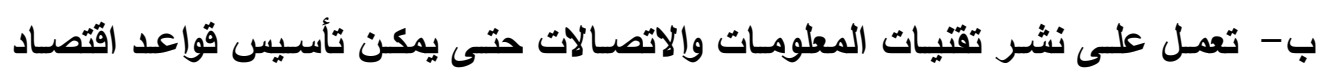

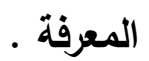

ت- توفر بنية تحتية متطورة للاتصالات والمعلومات، بما يسمح بتدفق المعلومـات بسهولة

ويسر

ث - تسرع عملية التنمية، نتيجة لتعدد أدوار المعرفة فى عملية التنمية وتباين مجالاتها .

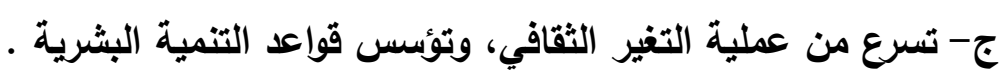
ح- تنشىء المعرفة أسواقاً جليدة من خلال الإبداع والابتكار على عكس السلع المادية . خ- انخفاض سعر المنتج المعرفي باستمرار مع زيادة أرباحه على عكس المنتج المادى .

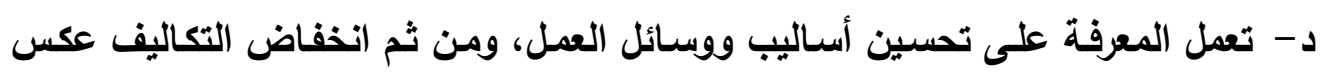
المنتجات المادية . ومن البحوث والدراسات التى أثثارت الى أهمية المعرفة ما يلى:

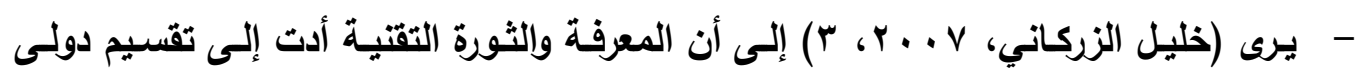

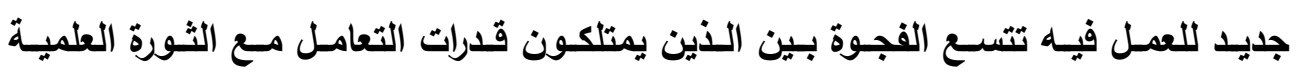


والتكنولوجية والذين لا يتمكنون من ذلك، الأمسر الذى يفرض العديد من التحديات على العالم العربي - مالنوله

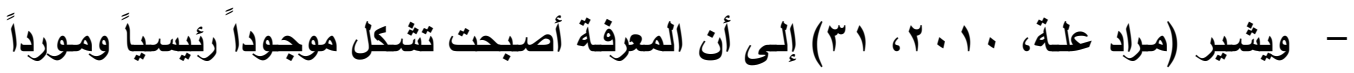

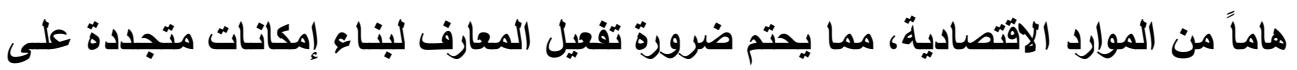

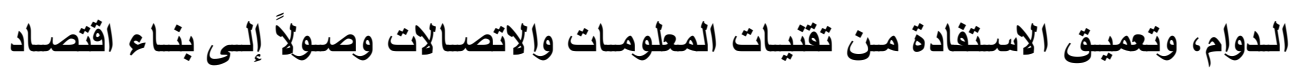

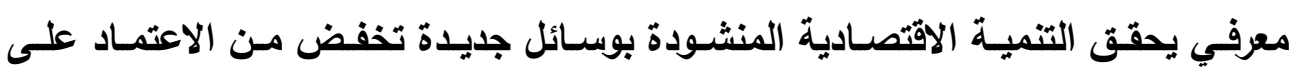

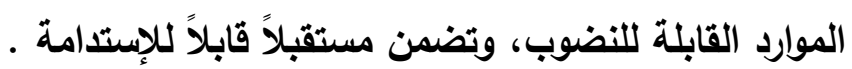

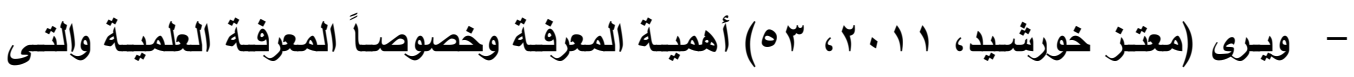

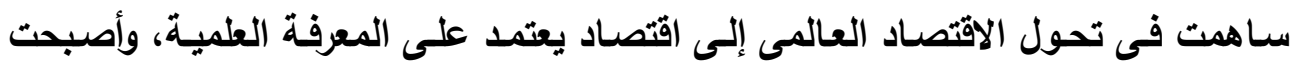
قدرة أى دولة تثمثل فى رصيدها المعرفي .

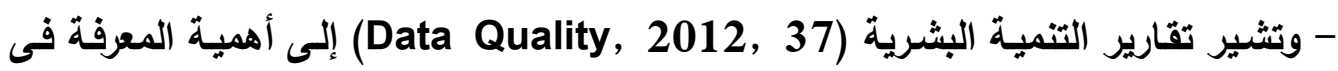

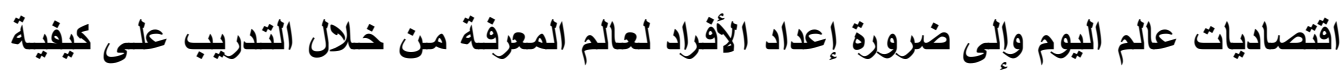
التعامل مع البيانات وتبويبها وإنتاج المعلومات والتعامل معها وصولاً إلى إنتاج المعرفة .

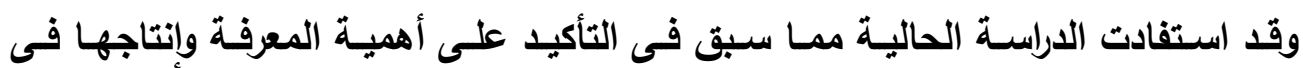

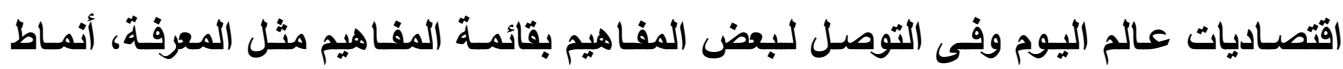

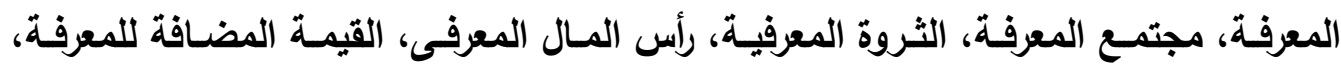
مؤثرات قياس المعرفة . ع - اقتصاد المعرفة وأهميته: شهر مفهوم اقتصاد المعرفة تطوراً كبيراً في العقود القليلة الماضية مـع اتسـاع استخدام شبكة الإنترنت والتجارة الإكترونية والدفع الإكتروني، ويقوم هذا الاقتصاد على وجود بيانات

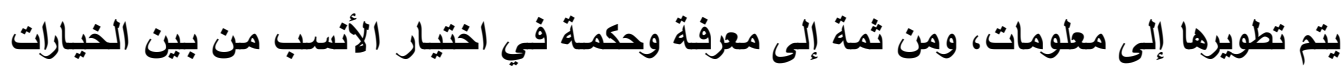

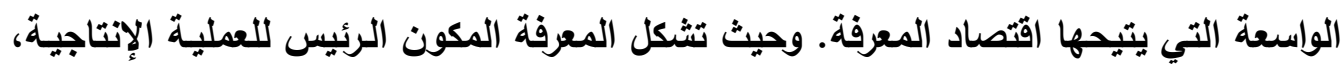
وأسـاس القيمـة المضافة التى يتضـاعف نموهمـا باستخدام تقتيـة المعلومـات والاتصـالات فئان

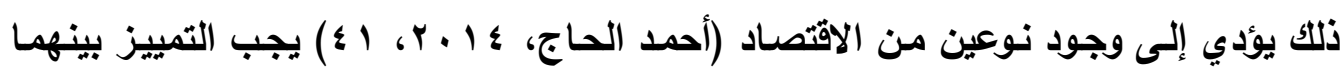


- اقتصـاد المعلومـات: وهـو الاقتصـاد المبنـي على المعلومـات والمعرفـة الممزوجـة بتقتيـات

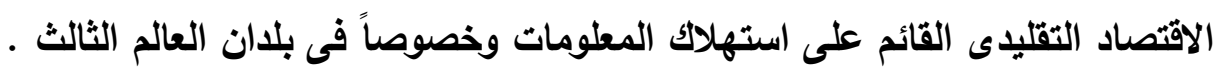

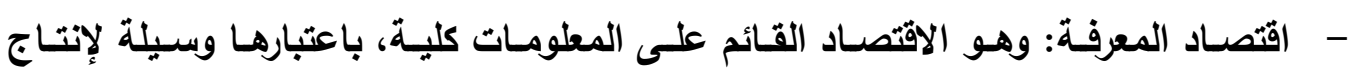

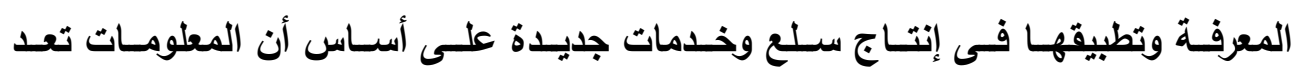

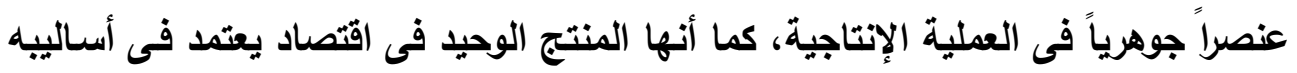
الإنتاجية وتسويقه على المعلومات وتقتياتها . ولقد تعدد تعريفات اقتصاد المعرفة:

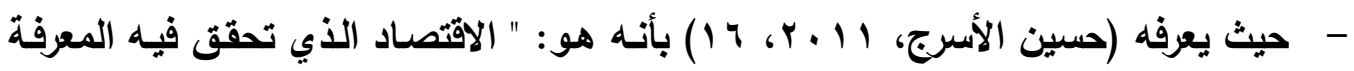

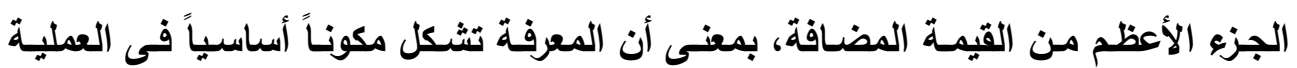

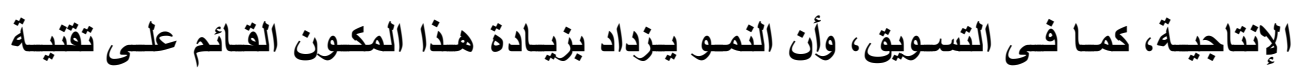

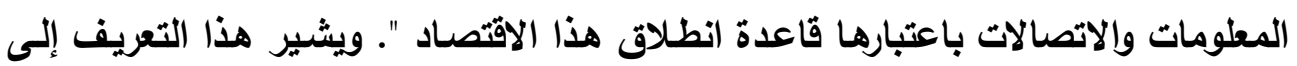

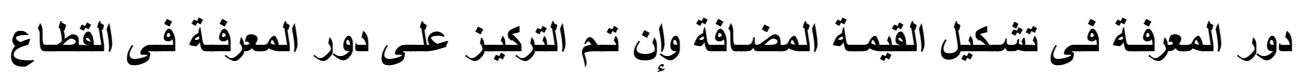
الاقتصادي دون غيره من القطاعات المجتمعية، كنلك أشـار إلى دور تكنولوجيا المعلومـات والاتصالات فى هذا الاقتصاد الجديد القائم على المعرفة .

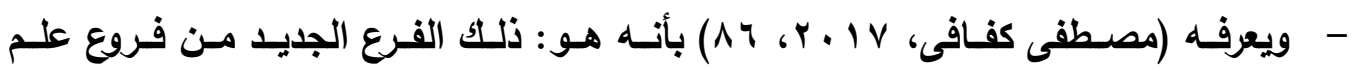

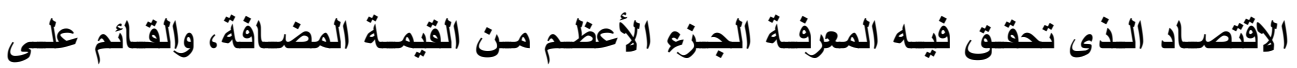

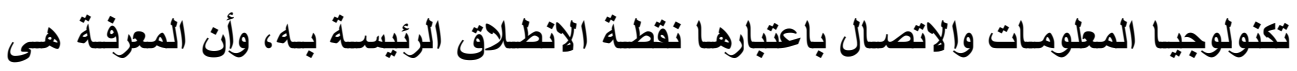
العنصر الرئيس فى العملية الإنتاجية والتسويقية ـ ويشير هذا التعريف إلى ظهور فرع

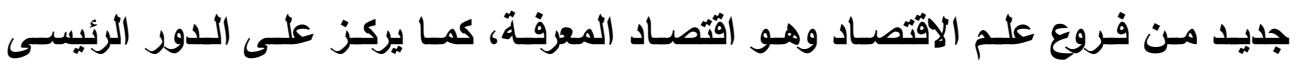

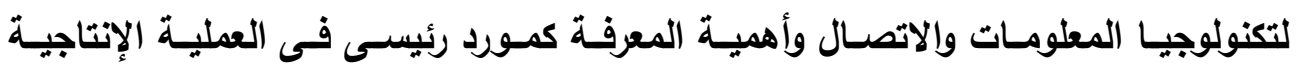
وإلتسويقية، ودور المعرفة فى تحقيق القيمة المضافة كما فى التعريف السابق .

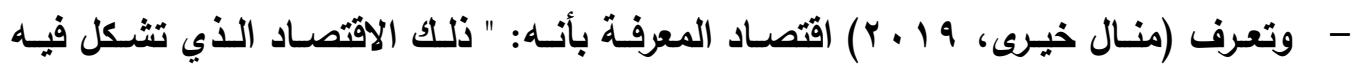
عمليات إنتاج المعرفة وتوظيفها العامل الرئيس فى العملية الإنتاجية والخدمية، والمكون الأعظم للقيمـة المضـافة للمجتمعات الاقتصـادية الدولية التى تعتمد على التوافر الموسـع لتكنولوجيا المعلومات والاتصالات وشبكات الإنترنت فى مختلف أوجه النشاط الاقتصادي. 
- ويناء على ما سبث من تعريفات لاقتصاد المعرفة فإن الباحث يعرفه إجرائياً في هذا البحث

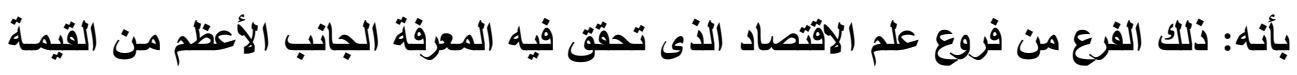

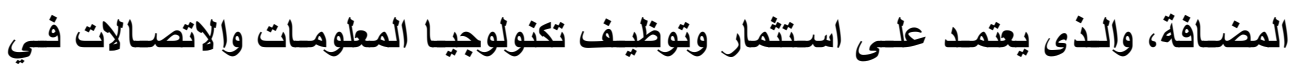
مختلف أوجه النشاط الاقتصادى، وتمثل المعرفة العنصر الرئيس في جميع مراحل العملية

$$
\text { الإنتاجية (التخطيط - التتفيذ - المتابعة - التسويق - التقويم..) . }
$$

\section{ه- - ركائز الاقتصاد المعرفي:}

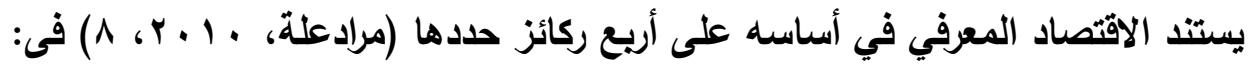

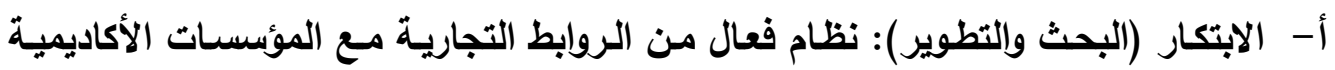

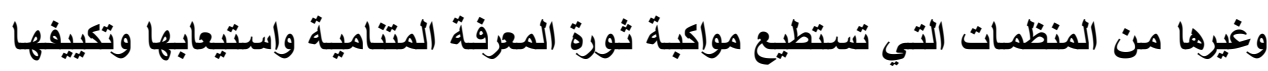

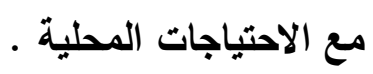

ب- التعليم: وهو من الاحتياجـات الأساسية للإنتاجية والتتافسية الاقتصادية، حيث يتعين

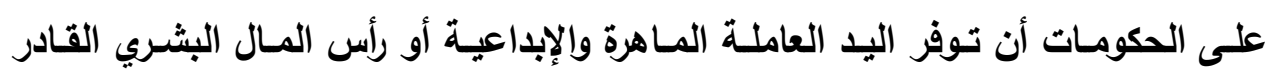

$$
\text { على إدماج التكنولوجيا الحديثة في العمل والإنتاج • }
$$

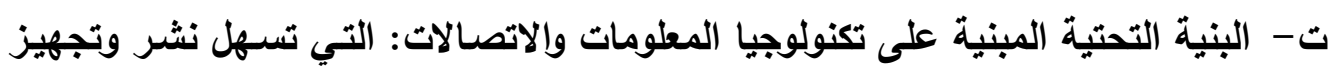
المعلومات والمعارف وتكييفها مع الاحتياجات المحلية، لدعم النشـاط الاقتصادي وتحفيز

$$
\text { المشاريع على إنتاج قيم مضافة عالية . }
$$

ث - الحـوافز: والتـي تقوم على أسس اقتصـادية قويـة تستطيع توفير كل الأطر القانونيـة

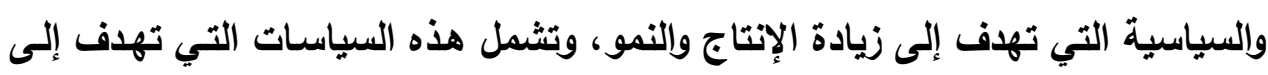

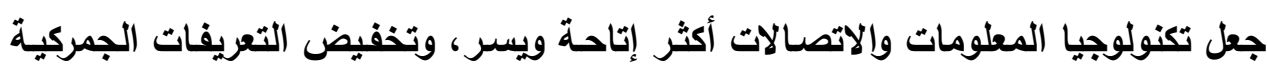

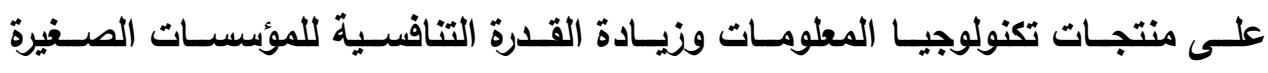
والمتوسطة ـ ويمكن توضيح أهم مرتكزات الاقتصاد المعرفى في الثكل التالى: 


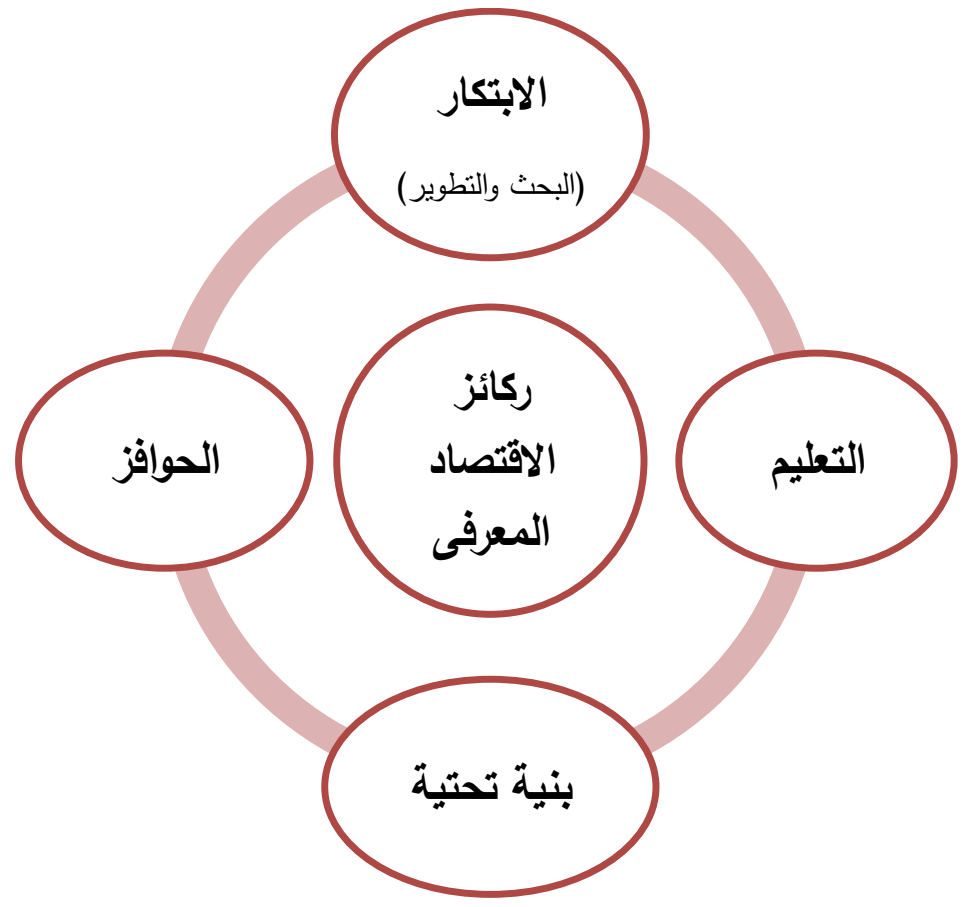

شكل رقم (1) يبين مرتكزات الاقتصاد المعرفى

وتتفق تلك الركائز مـع نتائج العديـ مـن الدراسـات والبحـوث التى أثـارت إلى أهميـة ودور

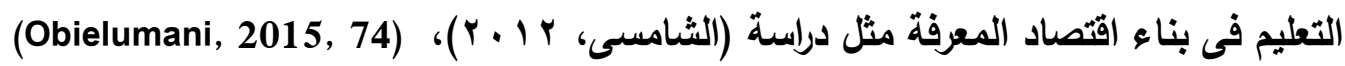
- (Gul, Showkeen,2015) (Kivinen \& Nurmi ,2014) - ويشـير (Hana,2008 ) أن الاهتمـام بتطـوير التعليم والاهتمـام بتكنولوجيـا المعلومـات وإنتاج المعرفة هو الأساس للانتقال من الاقتصاد التقليدي إلى اقتصاد المعرفة .

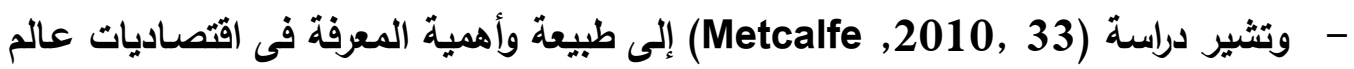
اليوم وأن مدى تمـايز الاقتصـاديات يقوم على ثـلاث عناصـر وهـى (مدى تتـوع المعرفة،

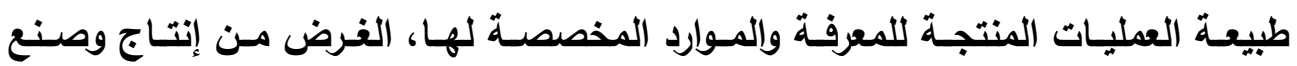
المعرفة)، ولذلك أوصت الدراسة بضرورة تطوير الهياكل التعليمية والاتجاه بها نحو المزيد من التكنولوجيا . - متؤكد دراسة (Santiago \& Soliz, 2012) على أهمية الاستعداد لمجتمع المعرفة من خلال التوصية بتطوير التعليم واكتساب المهارات الأساسية، وقدرات التفكير الناقد اللازمين للاندماج فى مجتمع المعرفة وإنتاج المعرفة . 
- ويرى كل من (Sam \& Van Der Sijde, 2014, 891) ضرورة إحداث نقلة نوعية فى النظام التعليمي من أجل التحول نحو اقتصاد المعرفة، من خلال التحول من التعليم

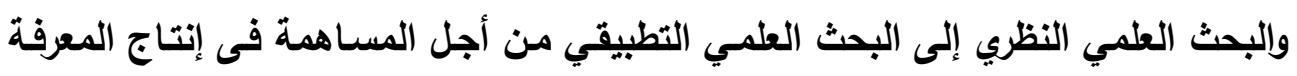
وتطوير وتنمية الاقتصاديات من خلال المشاريع العلمية المشتركة .

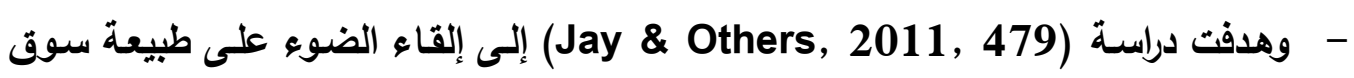

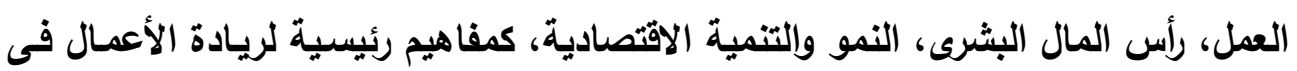

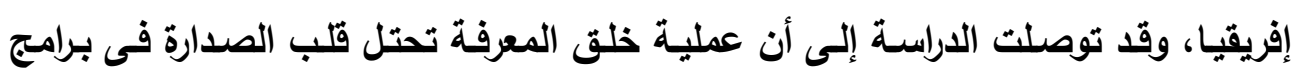

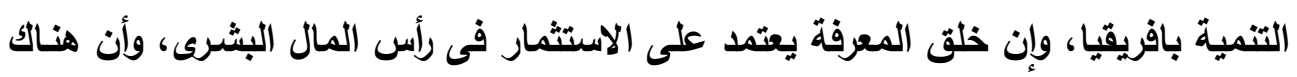

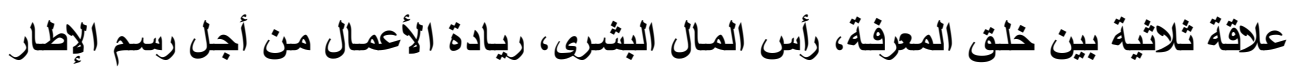
المؤسسى والقياسى لتخريج رواد الأعمال . - وهدفت دراسة (Cristina \& Others, 2017, 2) إلى اختبار مدى تأثير المعرفة على الفي

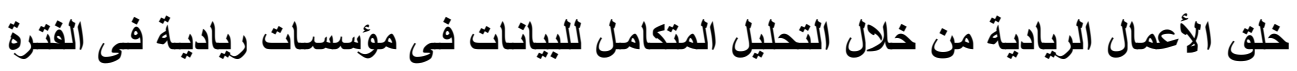

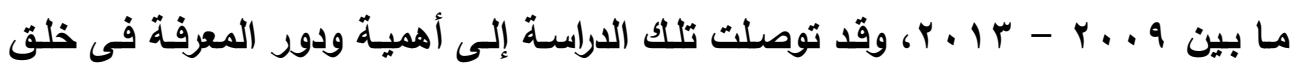
المشاريع الريادية . - المين - ويثير (Yagoub ,2017, 388) إلى تأثير تدريس ريادة الأعمال ويرامج التدريب فى

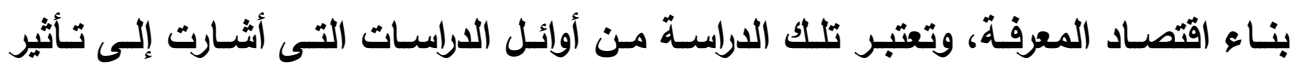

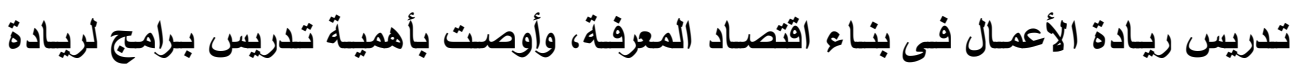

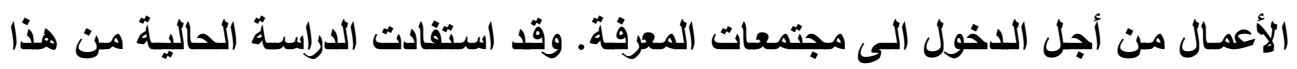

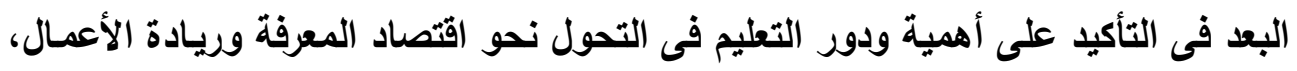

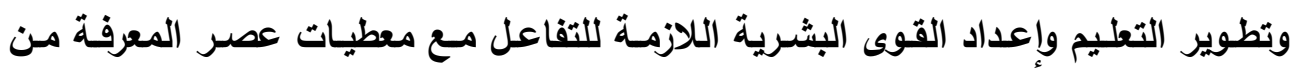

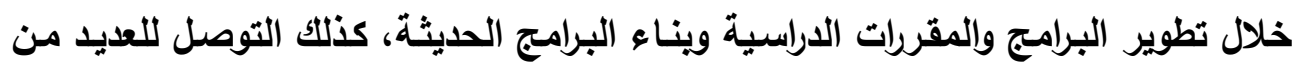

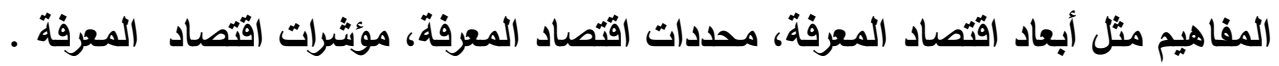




\section{1}

يتميز الاقتصـاد المعرفي بالعديـ مـن الخصـائص حددتها الدراسـات والأدبيـات (أثـرف

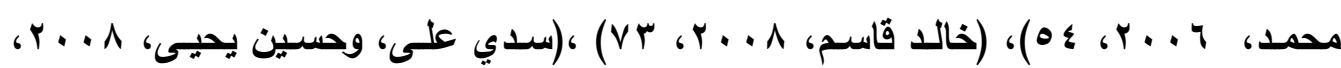

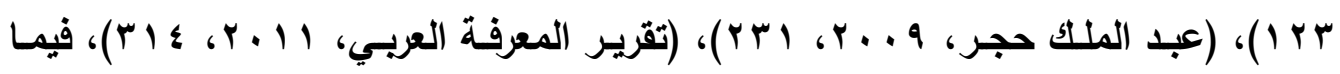
يلى

أ- - أصبحت المعرفة العامـل الرئيس فى الإنتاج في الاقتصـاديات الحديثة، ويـلك تحولت

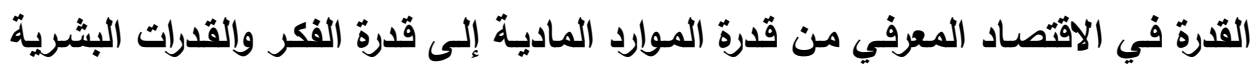

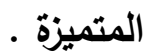

ب- تعدد وتنوع مجالات القيمة المضافة فى اقتصاد المعرفة بتوليد منتجات وخدمات معرفية وغير معرفية جديدة أكثر إثباعاً للمستهلكين بل وإنتاج سلع وخدمات مصممة خصيصاً

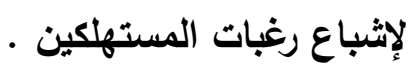

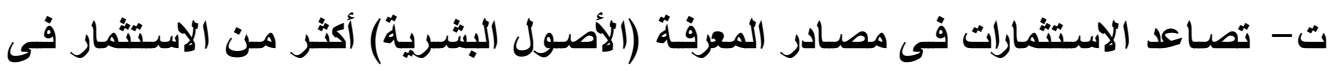

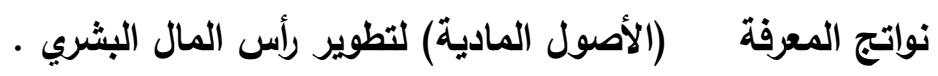

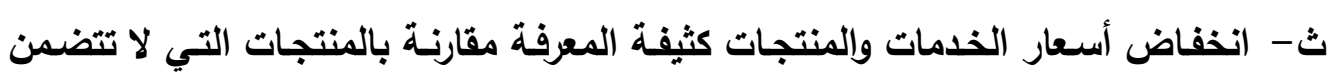
كثافة معرفية . ج- تغير مفهوم السـوق بمعنـاه وحيزه المكاني فى اقتصـاد المعرفة بفضل الاعتمـاد على التقتية الإكترونية والشبكات الإكترونية . ح- لم تعد الموجودات الفيزيائية للشركة تشكل عاملاً أساسياً فى التقويم المسالي للشركة، أو الأكئه

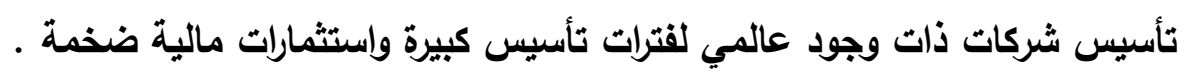

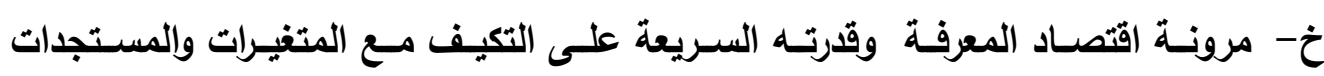
الحياتية مرنة

د - حدوث تغيرات هيكليـة في الاقتصـاد الجديد وزوال أنشطة وقطاعـات وظهور أنشطة وقطاعات أخرى، ممـا ترتب عليه تغير جذري في تركيبة قوى العمل وتزايـ دور قطاع الائه

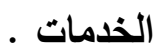
ذ- تصاعد الاعتمـاد على القوى العاملة المؤهلة والمتخصصة فى التقيات الجديدة وعلى

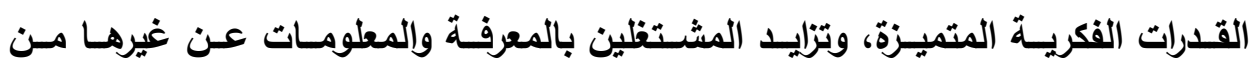


القطاعات الأخرى، بل وإختفاء مهن تقليدية ونشأة مهن أخرى تحتاج إلى قدرات معرفية عالية . ر- ظهور مؤثـرات ومعايير جليدة للكفايـة الاقتصـادية تعتمـ على مـا تملكـه الثـركة من

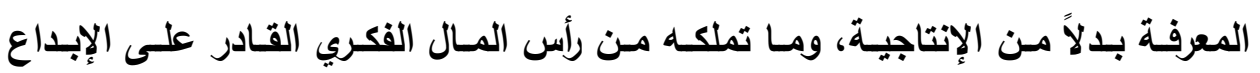
والابتكار . ز - تزايد الاعتماد على عمليات البحث العلمي والتقتي لإنتاج معرفة جديدة بتطبيقات عديدة

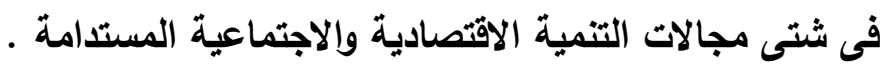

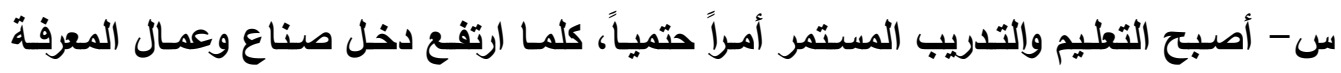
كلما، ارتفعت خبراتهم وكفايتهم وخبراتهم فى مجال إنتاج الجديد من المعرفة .

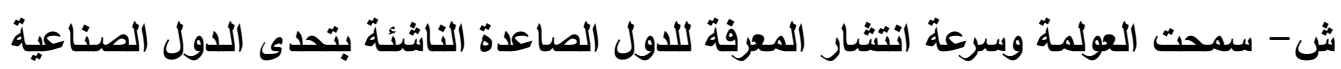
الكبرى فى الوصول إلى المستهلكين والحصول على حصة من السوق العالمي . ص - انتهاء ظاهرة التوظف مدى الحياة، وتغير التركيب الاجتماعى لقوى العمل ودخول المرأة

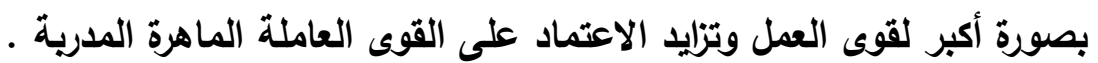
وقد أسفر هذا البعد عن اشتقاق العديد من المفاهيم مثل: مفهوم المعرفة، أنماط المعرفة،

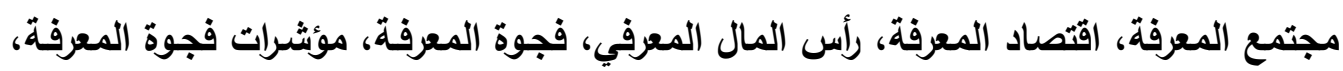

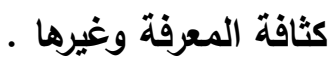

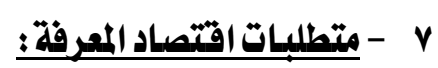
يمكن الإشارة إلى متطلبات اقتصاد المعرفة فيما يلى: أولاً: المتطلبات الاقتصادية وإلتنموية:

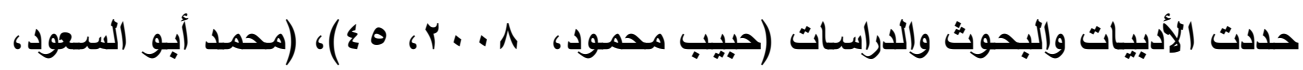

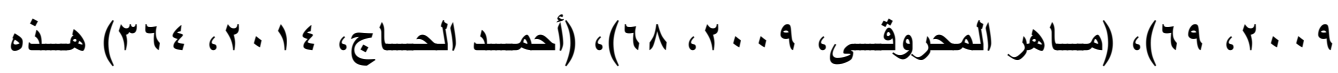

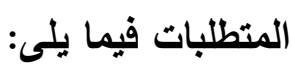
أ- تــوفير بيئة اقتصـادية كليـة مسـتقرة ومنافسـة، إيحـاد نظـم تعليميـة وتدريبيـة تيسـر للمـواطنين استخدام والحصول على المعرفة، إيجاد نظم ابداعية تجمع بين الباحثين ومؤسسسات الأعمال من أجل خلق منتجات وخدمات تتمتع بميزة تنافسية، توفير بنية

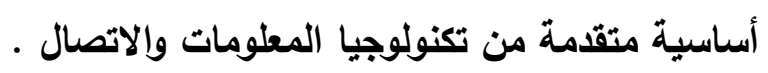


ب- تبنى الحكومـة خططاً للتنميـة المستدامة، محور ارتكازهـا توليد المعرفة وتوظيفها فى

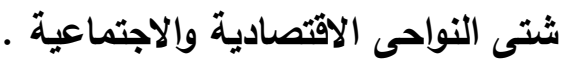

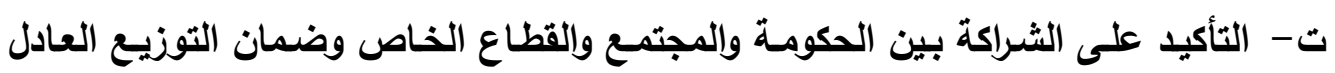
للموارد الاقتصادية. ث - إقامة الحكم الراثد على أسس اقتصاد المعرفة من خلال تحديث القوانين والتشريعات،

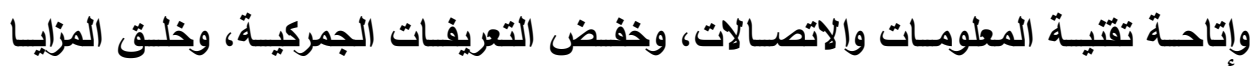
التنافسية . ج- توافر البنى التحتية المتطورة من تكنولوجيا المعلومـات، وتأسيس الحكومـة الاكترونيـة، وتدعيم المبادلات الإكترونية والتجارة الإلكترونية . وفى هذا الصدد تشير العديد من الدراسات إلى أهمية ودعم المبادلات الإكترونيـة نذكر منها:

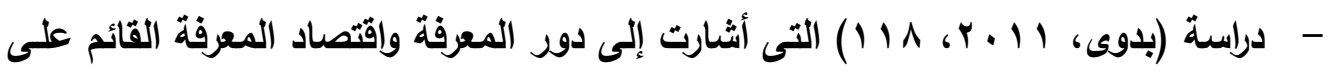
تكنولوجيا المطلومات فى تحقيق سهولة انسياب الخدمات المصرفية بكفاءة عالية، وأن

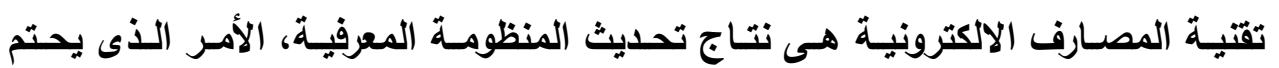
ضرورة إعداد الأفراد المؤهلين للتعامل مـع تكنولوجيا المعلومات وإنتاج المعرفة من أجل

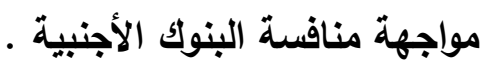

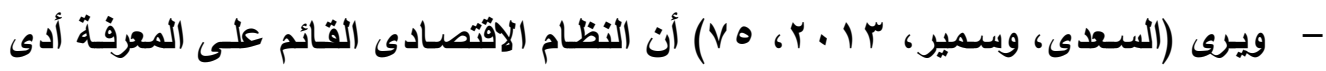

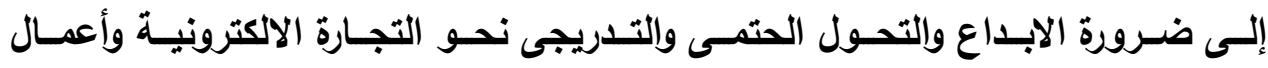
المصارف الاكترونية لما له من مزايا تنافسية من حيث التكاليف والفعالية، وقد أوصت

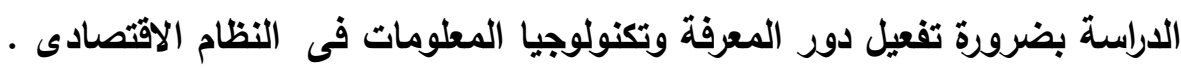
- وهدفت دراسـة ( Arvanitis, 2010 (

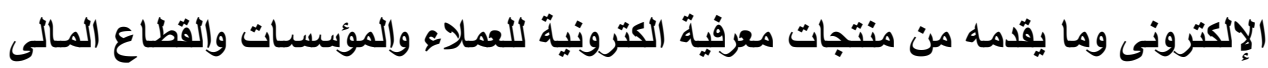

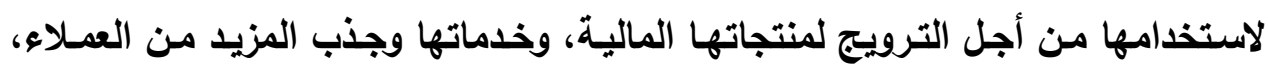
ويما يوصى بأهمية تفعيل دور التكنولوجيا فى المجتمع وخلق اقتصاد المعرفة . - ويشير كل من (Gullet \& Dinkins,2010 , 67 إلى أن عالم الاقتصاد والأعمال لابد أن بستوعب التطبيقات والعمليات الحديثة، فقد أحدثت ثورة المعلومـات نقلة نوعية 
فـى مجـال البنـوك والتمويل الاككترونس، ممـا يستوجب ضـرورة إمـداد الطلاب بالمفـاهيم

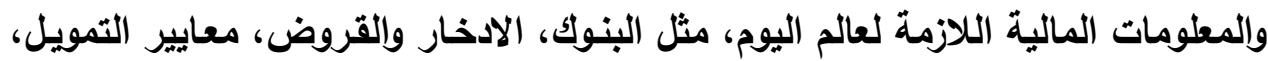
أعمال البنوك الاكترونية . ح- رفع المتطلبات المهارية لرأس المال البشرى فى ضوء الثورة التقتية ودعم نظم التدريب وتطويرها خ- تنميـة وتطوير رأس المـال البشـرى والفكرى مـن خـلال التـديب والتعليم، ودعم البحث والابتكار لتوفير أصول معرفية للعملية الانتاجية . د- تطوير التعليم والتدريب ودعم الجهود لمحو الأمية التكنولوجية . ذ- إتاحة فرص التعليم والتدريب المستمر، ودعم التدريب التحويلى فى إطار التعلم مدى ودئ الحياة . ر- تـوفير الاسـتثمارات فـ مجـال التعليم والبحث العلمس لتـوفير الفتيـين والتكنولـوجيين

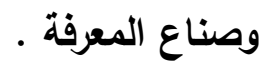
ز - جعل الإنسـان وإلعنصـر البشـى محور ارتكاز التتمية واسـتـامتها، وأن تحقق بـرامج

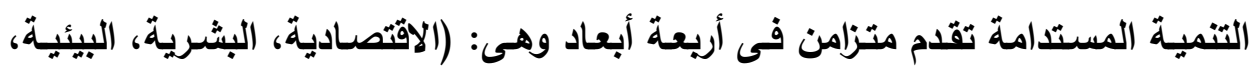
• والتقتية) س- جعل المعرفـة وصـناعة المعرفـة عنصـراً أساسياً لنجـاح التنميـة المستـامة، بتوظيفها لإحداث التطورات فى كافة المجالات الاجتماعية والاقتصادية والتقتية . ش - إعادة صياغة استراتيجيات النمو الاقتصادى لضمان نجاح التنمية البشرية المستدامة، ويما يعمل على زيادة معدلات الدخول والحد من البطالة والقضاء على الفقر . ثانياً : متطلبات التربية والبحث العلمى وإنتاج المعرفة :

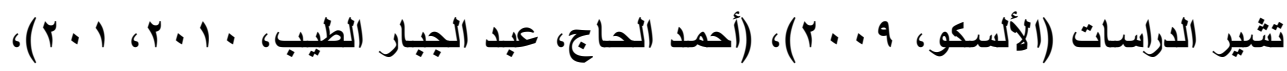

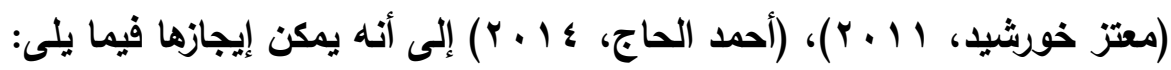

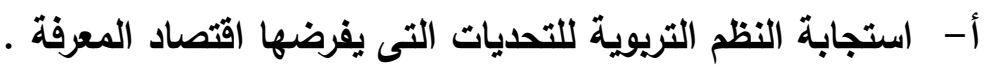
ب- التطوير الجذرى للأنظمة التعليمية لمواكبة التحديات العالمية المعرفية .

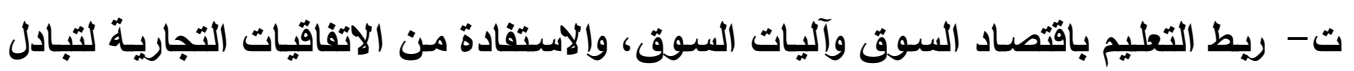

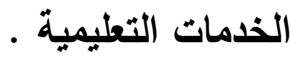


ث- أن تكون التربية المستدامة أداة لتوطيد العلاقة بين التنمية البشرية المستدامة والتتمية

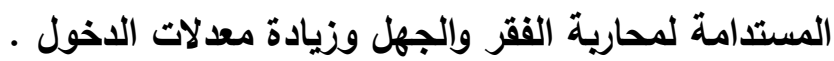

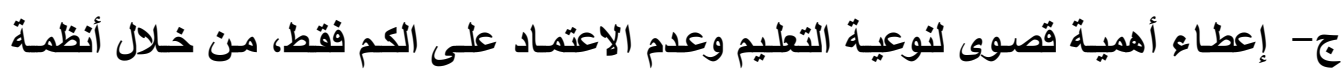

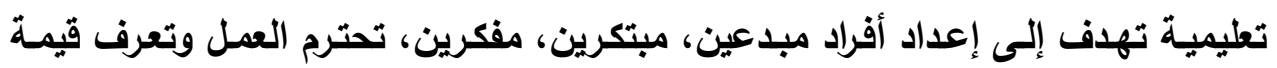
الإنتاج

ح- أن تحافظ النظم التعليمية وإلمناهج على البعد البيئى وتجديدها وضمان استدامة الموارد.

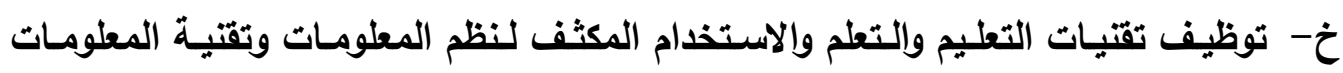
الرقمية

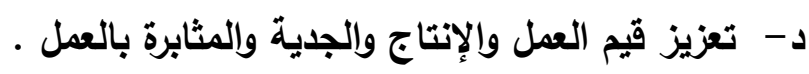

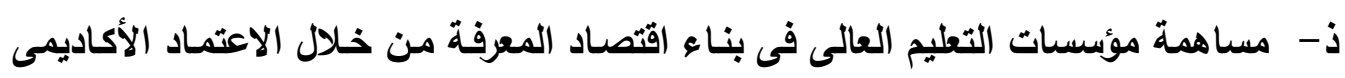

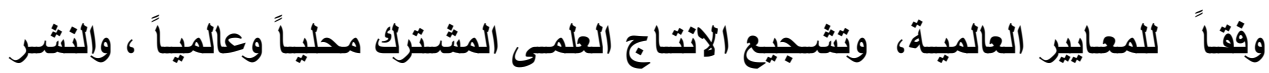

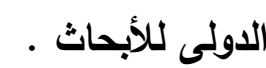
ر- أن تعمل نظم التعليم وخصوصاً العالى منها على توطين العلم والمعرفة بـداً من نشر

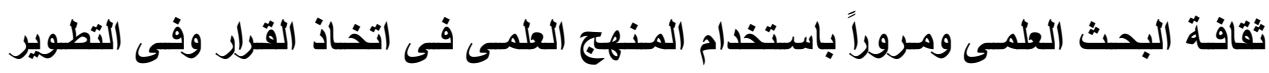

ووصولاًا إلي إعداد القنين والمختصين والعلماء والمبدعين والمبتكرين صناع المعرفة .

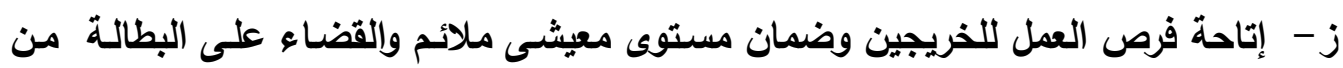
خلال التطوير المستمر للتعليم وريط التعليم بسوق العمل . س - إيجاد صيخ ومؤسسـات تعليمية جليدة مرتبطة باقتصـاد ومجتمـع المعرفة مثل الجامعة المفتوحة ، الجامعة الافتراضية ، التعليم عن بعد ، الجامعة الاكترونية . ش - أن تركز المؤسسات العلمية على إنتاج ونقل المعرفة، نشر المعرفة، استخدام المعرفة . ص - اعتماد التطوير المستمر للبحوث العلمية فى مجال نظم المعلومات والتجارة الإكترونية.

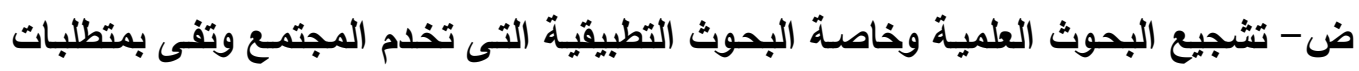
إنتاج المعرفة . ط- تحقيق التفاعل الايجابى بين المجتمع والجامعة، ودعم التفاعل بين الجامعات ويعضها

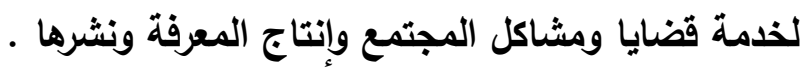


ظ- ضرورة إنشاء حاضنات تقنية المعلومات التى تتبنى أفكار المبدعين والمبتكرين وتحويلها

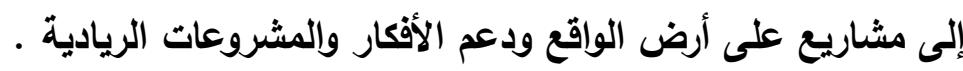

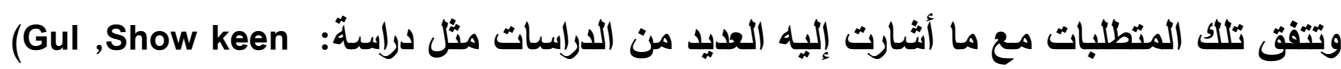

(Rakeh \& Others, 2015) ، (Sam \& Van Der , 2014) ،(Kivinen \& Nurmi, 2014) (Lucy,،(Ken Chukwu \& Mulugeta ,2018) ، (Yagoub,2017) (،(Obielumani ,2015) (2018، وقد استفادت الاراسة الحالية من هذا البعد فى التأكيد على تطوير التعليم من خلال

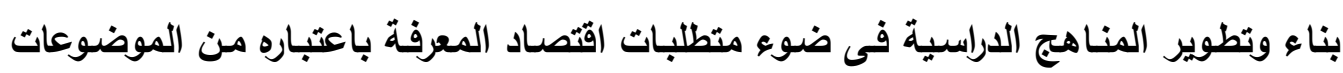

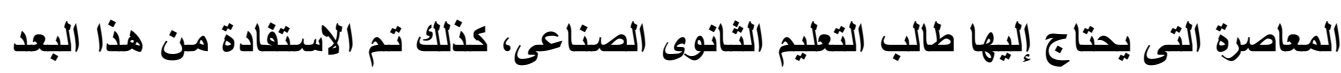
فى استخلاص العديد من المفاهيم المرتبطة .

\section{المحور الثالث: الملدرسة الثانوية الصناعية:}

تعريفها: هى تلك المدرسة التى تقوم بإعداد فئة الفنى التلازم للعمل فى قطاعات الإنتاج والخدمات وإلتصنيع، ومـدة الدراســة بها ثلاث سنوات، يلتحق بها بها الطالب بعد إتمام مرحلة

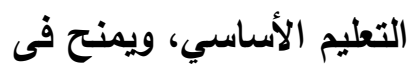
نهايتها شـهادة دبلـوم المدارس الثانويـة الصناعية (نظام السنوات الثثلاث) ويحدد بهـا نـوع

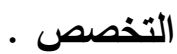

\section{أهداف الملدرسة الثانوية الصناعية:}

تفصيلاً لما نصت عليه القوانين فإن أهداف تلك المدارس الصناعية يمكن تحديدها فى ثلاثة أبعاد متكاملة كما يلى

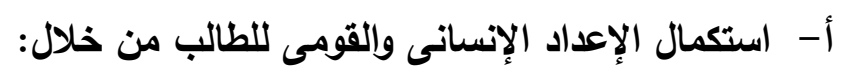

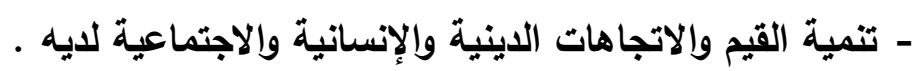

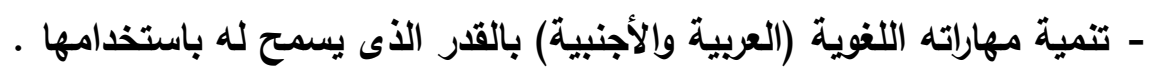
- فهم أساسيات المعرفة العلمية والإنسانية المعاصرة . - تنمية الاتجاه الإيجابي نحو العمل فى مختلف صوره . - تنمية قدراته الجسمية على نحو يمكنه من الحياة فى صورة صحية سليمة . 
ب- - إعداد الطلاب لمواصلة التعليم والنمو العلمى والمهنى من خلال: - إنماء المفاهيم العلمية الأساسية التى يتطلبها التعليم فى مستوياته العليا.

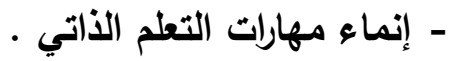
ت- إعداد الطلاب فى المجالات الصناعية على مستوى الفنى من خلال:

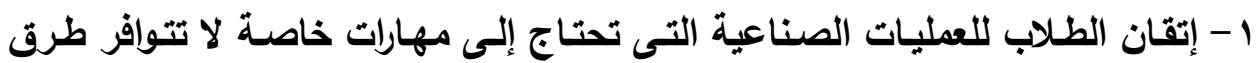
اكتسابها فى محيط العمل الصناعى العادى. r - إكساب الطلاب القدرة على أداء العمليات الصناعية حسب الأصول القنية الصحيحة ץ- تهيئة فرص الترابط المهنى فى الحرف الصناعية المتصلة ببعضها، والتعرف على

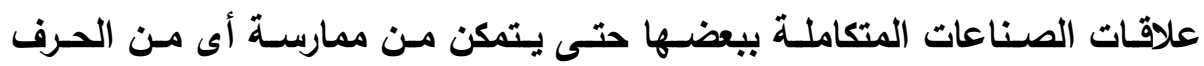

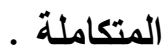

ع - إتقان استخدام العدد وإلماكينات طبقاً لقواعد الأمان والسلامة. ه- إكساب الطلاب القدرة على معرفة المصطلحات الفنية ومرادفاتها بلغات أجنبية .

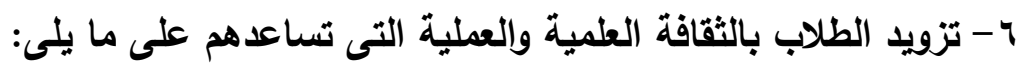
- انتقاء الخامات اللازمة للإنتاج من حيث المواصفات والخواص الملائمة . - معرفة التوزيع الجغرافى للثروات المعدنية المحلية، ومصادر القوى والخامات. - دراسة كيفية تركيب الآلات وتتشغيلها وصيانتها V - إكساب الطلاب الصفات التى تؤهلهم مستقبلاً للأعمال القيادية فى محيط العمل . من الملاحظ أن هذه الأهداف قد أكدت على ضرورة تحاشسى التخصص الضيق، وذلك

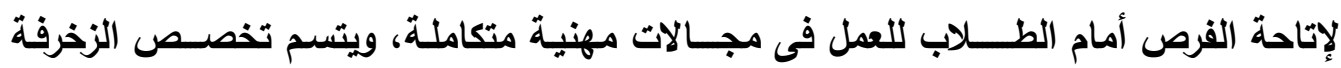

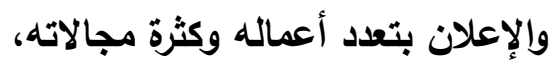

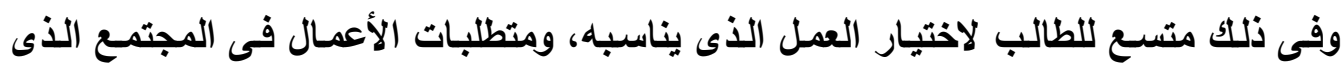

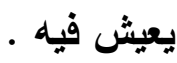




\section{المحور الرابع: تخصص الزخرفة والإعلاز:}

فنى الزخرفة والإعلان: هو الطالب خريج مرحلة التعليم الأساسى والذى يلتحق بتخصص الزخرفة والإعلان وهو أحد التخصصـات التى تتضمنها الشعبة الفرعية للزخرفة (مجموعة الصناعات

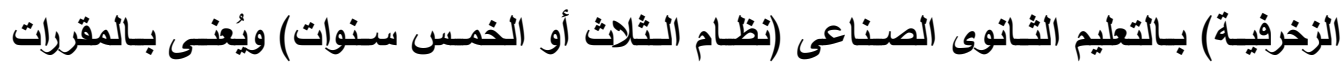
الاراسية اللازمة لإعداد الفنى والفنى الأول الذى يقوم بواجبات ومهام هذا التخصص . تخصص الزخرفة والإعلان: يعد تخصص الزخرفة والإعلان أحد التخصصـات التى تضمها المدرسـة القتية الصناعية

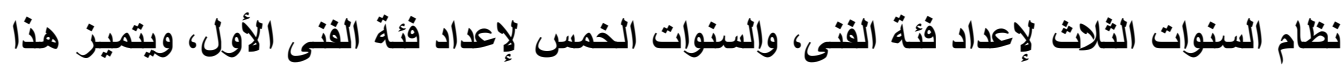
التخصص بتعدد أعماله وكثرة مجالاته ويضم أريعة أقسام رئيسية: القسم الأول وهو الخاص الاص

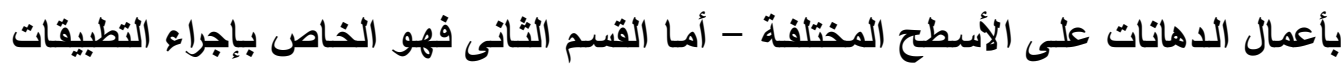

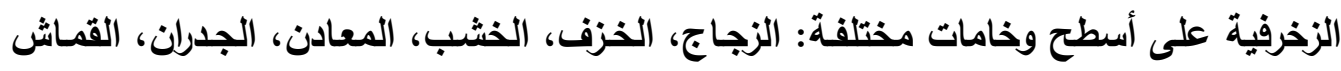
- أمـا القسم الثالث فهو الخاص بتصميم الإعلانات والثـعارات وأغلفة الكتب وغيرها - أمـا القسم الرابع والأخير فهو الخاص بأعمال التنسيق واللديكور . وهذا التنوع يساعد الطالب على الإعلى اختيار أنسب هذه الأقسام والمجالات بالنسبة له والتتى تتفق مع قدراته وميوله، ويالتالي تكون لايه الرغبة فى استمرار التعلم والتطوير ليصل إلى درجة الإبداع التى نرجوها في أداء خريجى لإنى

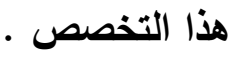

\section{أهمية تخصص الزخرفة والإعلان:}

يعد تخصص الزخرفة والإعلان أحد أهـم المصـادر الرئيسـة لإمـاد سـوق العمل والتوفـاء

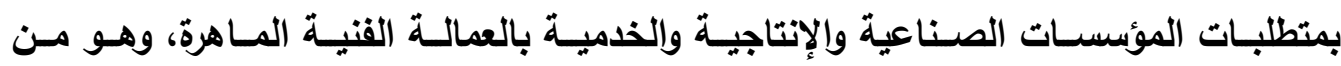

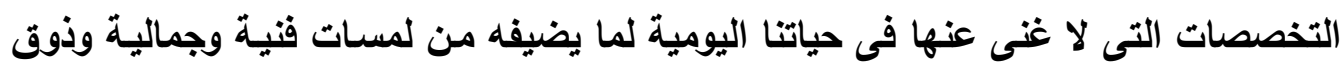

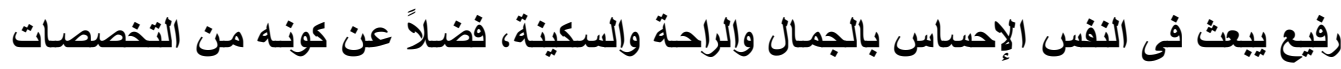
المكملة لجميع التخصصات الأخرى، ويظهر ذلك واضحاً فى مجالات التشييا والبنـاء والقرى باته

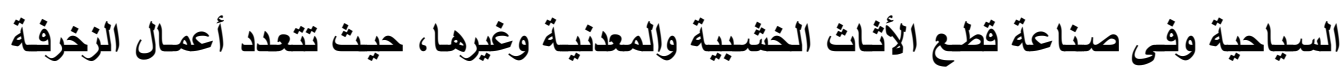

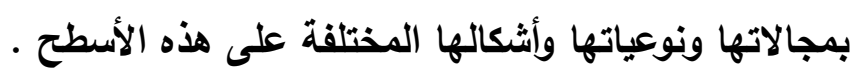
أهداف تخصص الزخرفة والإعلان: 
تتمثل الأهداف العامة والخاصة لهذا التخصص فيما يلى (وزارة التربية والتعليم، ج . . ؟): (أ) الأهداف العامة:

1 - اكتــاب المهـارات الفنيـة لتنميـة قدرة الخـريج على أداء العمـل فـى مجـال تخصصـه،

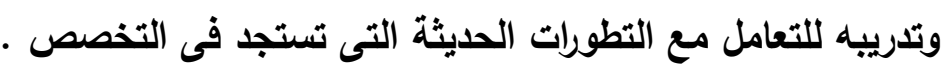

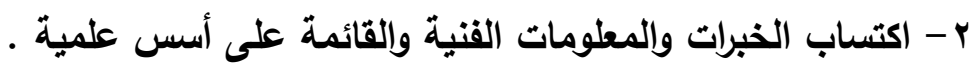

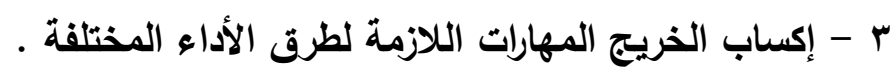
ع - مواجهة المشكلات القنية التى تحدث فى أساليب العمل . ه- الإلمام بطرق صيانة المعدات والآلات التى يستخدمها الخريج .

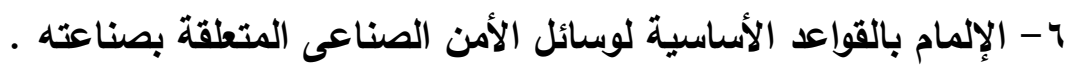

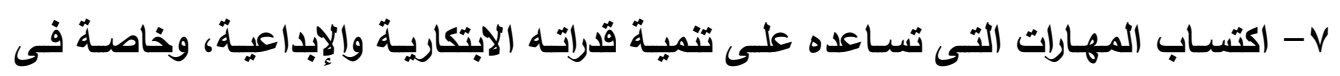

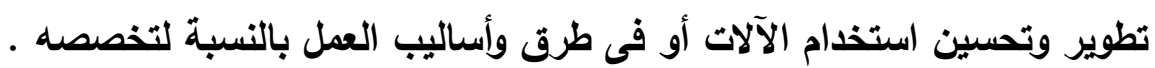
1- تنمية الاتجاهات السلوكية المفيدة لمجال صناعته. 9 - إكسابه القرة على التكيف مع الأعمال المستحدثة وفقاً لظروف العمل.

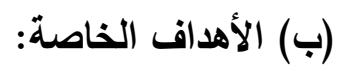
تقتضى أن يتحقى لاى خريجى تخصص الزخرفة والإعلان الأهداف الآتية؛ وفقاً لمسا جاء فى الإطار

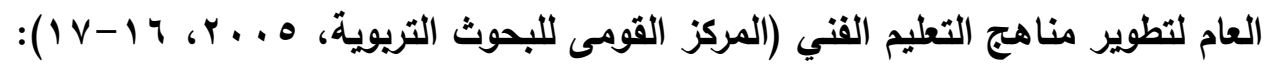
1 - التعرف على العدد والأدوات المستخدمة فى تخصص الزخرفة والإعلان .

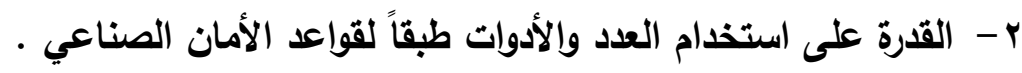

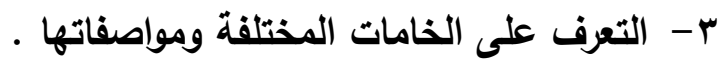
ع - التعرف على العوامل المسببة لتلف الدهانات والعمل على تجنبها وعلاجها . ه- القدرة على إعداد وتأسيس الأسطح المختلفة قبل دهانها . צ- القدرة على تنفيذ الخطوات الخاصة بالدهانات الزيتية وإلسيليلوزية . - اكتساب مهارات عمليات الطباعة بالثاشة الحريرية (سلك سكرين). 1- القدرة على التذوق الفنى والإحساس بالقيم الجمالية وأساليب العرض المختلفة. 
9- القدرة على استخدام الخامـات والألكوان والعينـات فى تثكيل الخلفيات الخاصـة بعمليات

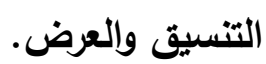

• 1 - اكتساب مهارات تنفيذ التقتيات الزخرفية كالكراكليه والريليف والكروماندل. 11 - ممارسة خطوات عمليات التذهيب والأكسدة على الأسطح المختلفة. r ا - القدرة على استخدام العناصر الزخرفية فى التشكيل البنائي لتصميم الإعلان.

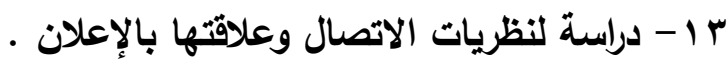
ـ ا - القدرة على مزج الألوان للحصول على درجات لونية مبتكرة . 1 - اكتساب العادات السلوكية الخاصة بتخصص الزخرفة والإعلان وآدابها. 17 - القدرة على حصر وتقدير تكاليف تنفيذ المنتج في صورة عمل مقايسات وفقاً لقواعد التظظيم الصناعى.

ويلاحظ ممـا سبق أن هذه الأهداف تنص صـراحة على تنميـة قدرة الطالب على مواجهة

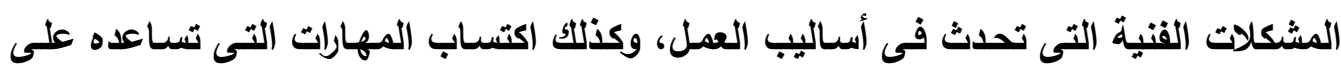

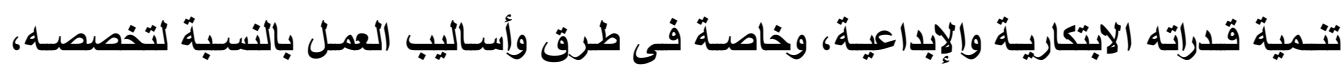
والتعامل مع المستحدثات التكنولوجية . الخطة الدراسية لتخصص الزخرفة والإعلان بـالملدرسة الثانوية الصناعية: تتضمن الخطة الدراسية مجموعة المقررات التالية: 1 - مقررات الثقافة العامة: وتشمل المواد التالية (التربية الدينية - اللغة العربية - اللغة الأجنبية - التربية القومية - الرياضيات - العلوم ....)، وتهدف إلى إكساب الطلاب الثقافة العامـة فى جوانب المعرفة

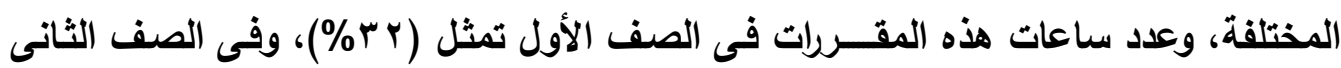

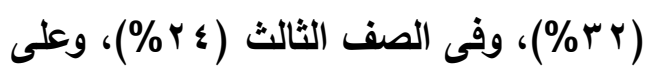

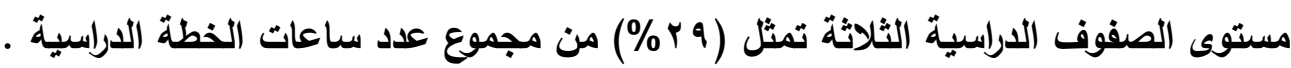
r - المقررات الفنية النظرية: وتثثمل المواد التالية (الرسم الهندسى - الرسم الفنى ـ (خامـات - معدات - عمليات تذوق فنى) - أمن صناعى وصحة مهنية - زخارف ..)، وتهدف هذه المقررات القتية إلى الى المئ إكساب الطلاب المعارف القنية التخصصية النظرية التى تساعدهم فى اتقان المقررات العملية 
(التدريبات المهنية) وسـولها وجودة تنفيذها، وعدد سـاعات هذه المقررات فى الصف الأول

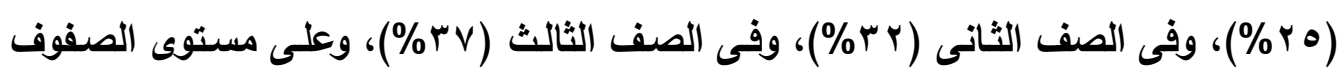

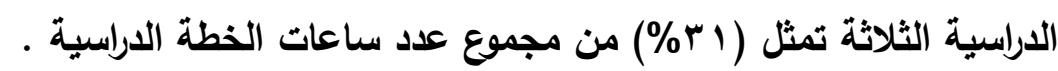
r- مقررات التدريبات المهنية: وهى التطبيقات العملية التى يمارسها وينفذها الطلاب داخل ورشـة الزخرفة، وتهدف إلى إكساب الطلاب المهارات العملية اللازمة لممارسة المهنة وهى مرتبطة بالمقررات الفنبة التخصصية النظريـة،

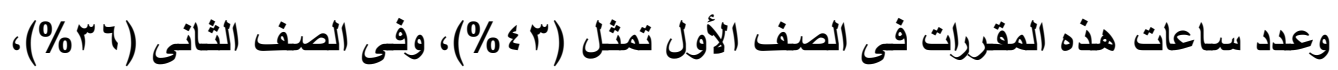

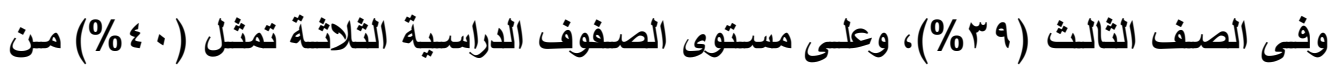

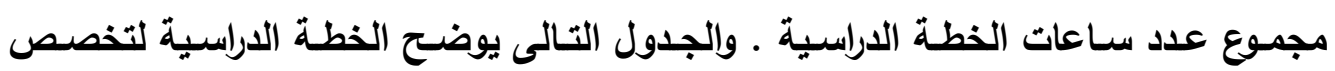
الزخرفة والإعلان بالمدرسة الثانوية الصناعية نظام السنوات الثلاث: 


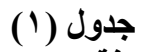

الخطة الدراسية لتخصص الزخرفة والإعلان بالمدرسة الثانوية الصناعية

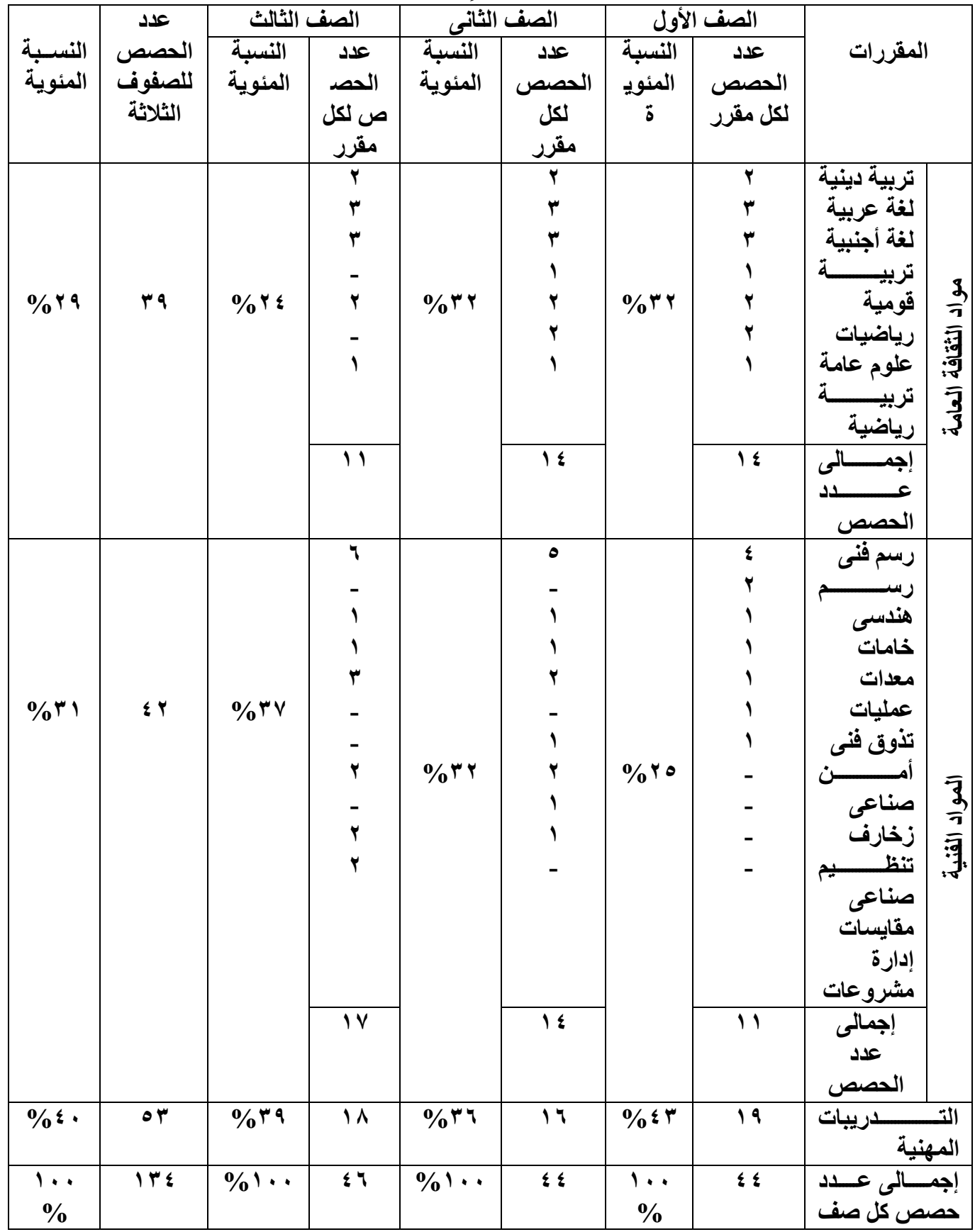


تعقيب: يتضح ممـا سبق أن الخطة الدراسية قد تناولت عديد من جوانب إعداد الطالب (المواد الثقافية - المواد الفنية النظرية - التدريبات المهنية) وعلى الرغم من أهمية

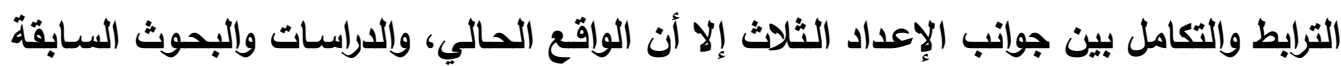
في ميدان التعليم الصناعى بصفة عامة وفى تخصص الزخرفة والإعلان بصفة خاصة يثيرا إلى افتقاد جوانب الإعداد إلى التكامل سواء بين المواد الثقافية والفنية أو حتى بين الموادية الفنية النظرية بعضها ببعض، فضلاً عن ضعف الارتباط والتكامل بين الجوانب الفنية النظرية

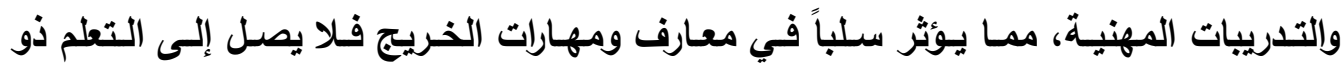

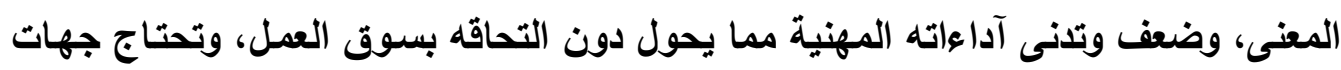

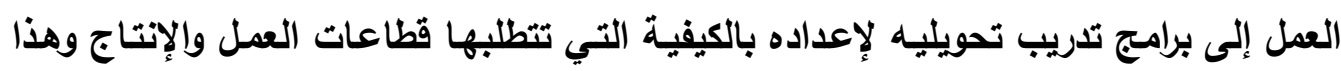

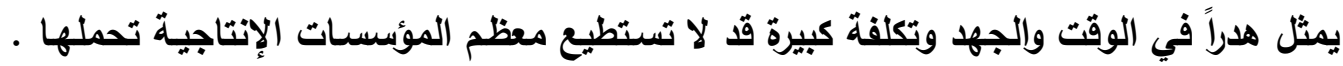

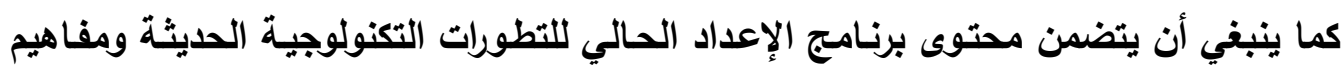
اقتصاد المعرفة، وتضمينها في المقرات الاراسية لمساعدة الخريج على تحقيق جودة التعامل

مeمها

\section{منهج تخطيطوإدارة الإنتاج:}

1- تعريفه: تعددت تعريفات منهج تخطيط وإدارة الإتتاج، حيث عرف بأنه: "هو أحد المقررات

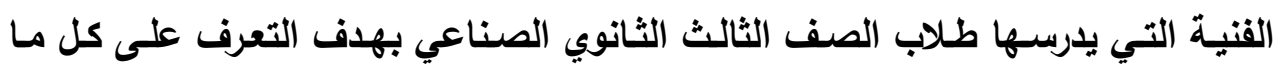

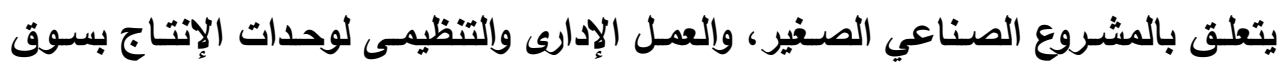

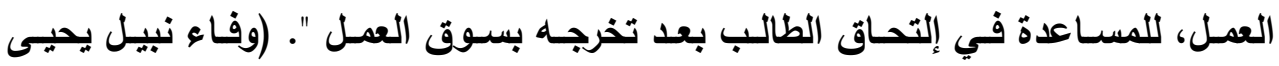

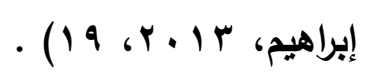

وعرف أيضاً بأنها: " العلم الذي يبحث في دراسـة إنثـاء المشروعات الصناعية وكيفية

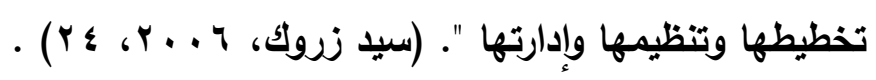

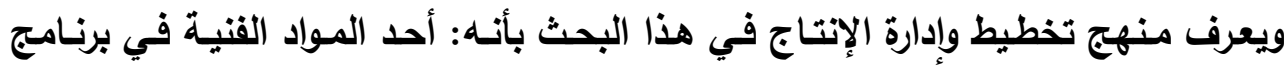

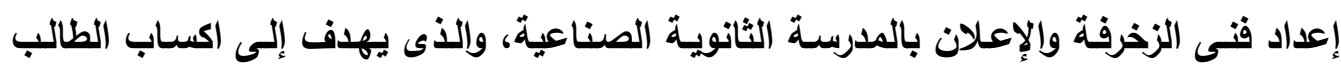

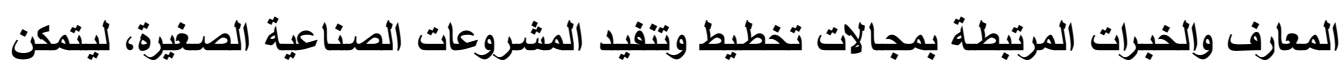

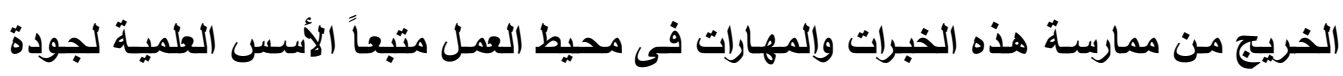

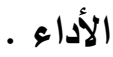


r - محتوى منهج تخطيط وإدارة اللإنتاج:

ويتضمن محتوى منهج تخطيط وإدارة الإنتاج الجوانب التالية:

أ- التخطيط:

وهو نقطة البداية فى العملية الإدارية، ويمثل التفكير المسبق قبل اتخاد القرار، والتخطيط هو "عملية فكرية لها منطق وترتيب ويبذل فيها جها لتوضيح هدف المشروع والبحث عن التهن أفضل الوسائل لتحقيق هذا الهدف، حيث ينطوي على عنصري التقدير والمرونة، أمسا التقدير ولئ فهو التقدير المستقبلى لعناصر العمل والإنتاج والظـروف المحيطة ثم المرونـة لمواجهـة

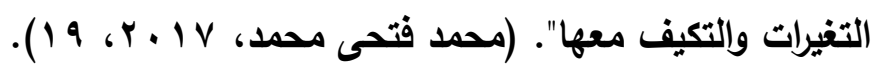

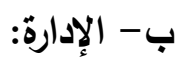
إن الاختيار الجيد للمشروعات الصناعات الصغيرة واعداد التخطيط ودراسات الجدوى لها،

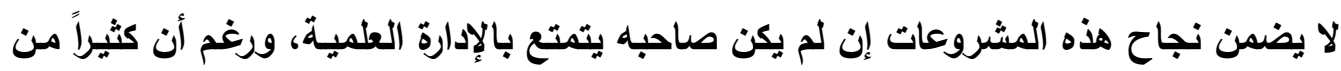

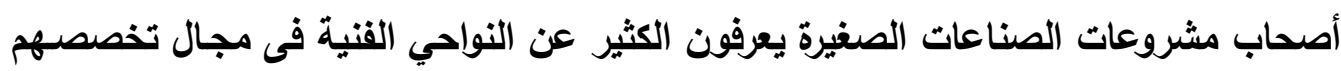

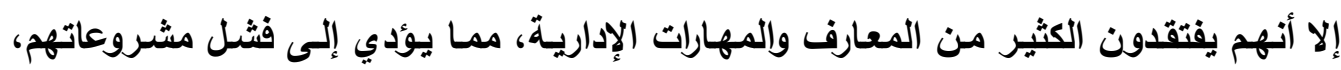

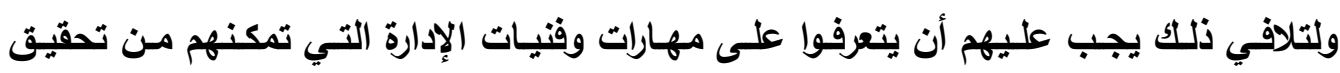

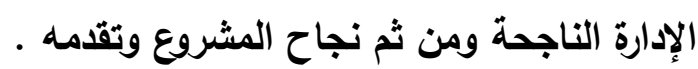

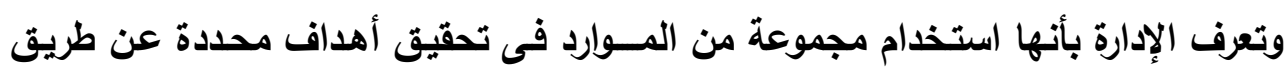

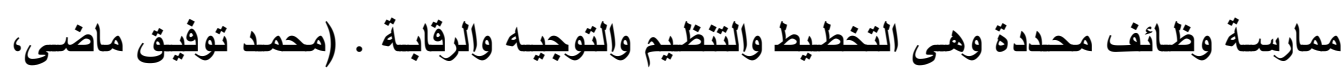

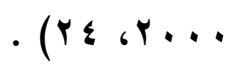

ويعرفها محمود زويل بأنها: "عملية التخطيط الذي يسبق التنفيد وتنظيم العمل بتقسيمه على العاملين وتدريبهز لتلبية احتياجاتهم، ورفع روحهم المعنوية وقياس النتائج المحققة

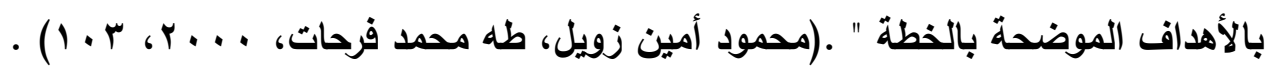

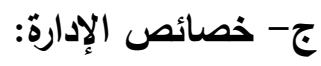

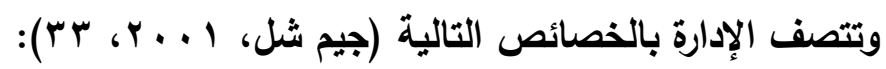

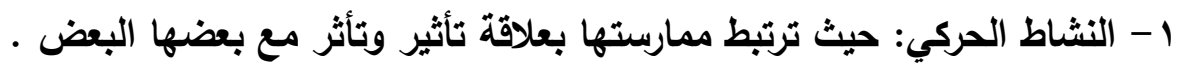

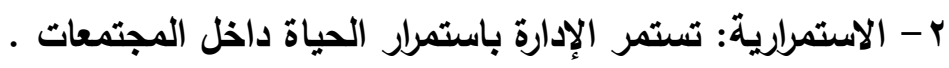

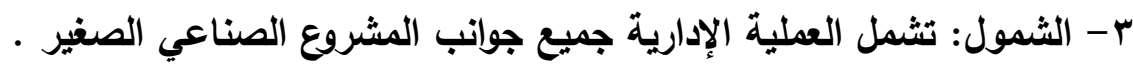


ع - التكامل: تتكامل وظائف إدارة المشروع الصناعي الصغير فى منظمة واحدة محددة .

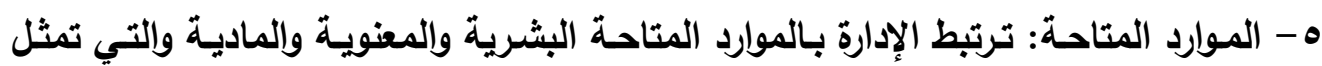
المدخلات اللازمة لإدارة عمليات المشروع الصناعي الصغير فى مجال التخصصات الفنية

\section{بهدف تحقيق النتائج المرجوة .}

د- إدارة العمليات الإنتاجية:

إن إدارة العمليـات الإنتاجيـة تتضـمن أنشطة التخطيط والرقابـة والمتابعة التـي يستخدمها

$$
\text { المدير صاحب }
$$

المشـروع الصـناعي الصغير لإنتـاج الأعمـال المطلويـة داخل مشـروعات الوحدات الصـناعية الإنتاجية . الإنيزوع. وإذا كان تسويث منتجات الصناعات مهم فإن جودة وسعر هده المنتجات أكثر أهمية، لأنـه من الصعب تسويق منتجات ذات جودة منحفضـة وسـعر عالي، مما يؤكد أهميـة إدارة العمليات الإنتاجية

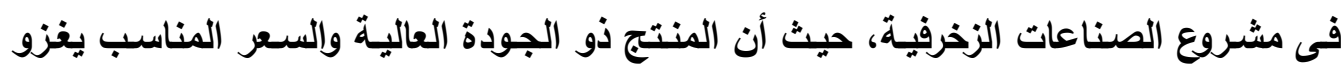

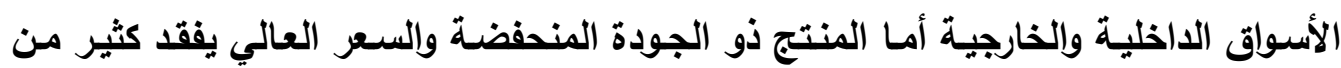

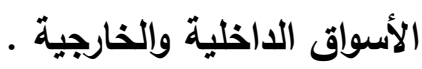
وعلى هذا فإن نجاح مشروع الصناعات الزخرفية الصغير يعتمد بالدرجة الأولى على نجاح إدارة العمليـات الإنتاجيـة داخل المشـروع، ويتمثل نجـاح إدارة العمليـات الإنتاجيـة في تقديم

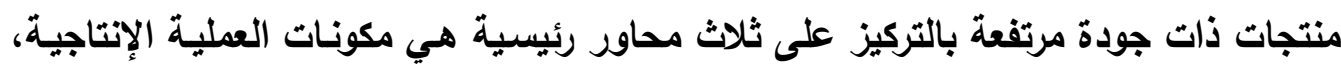

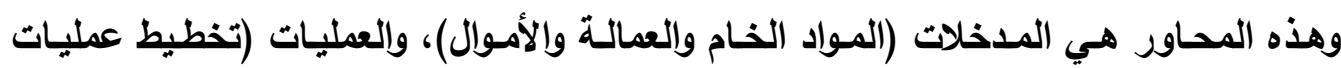
الإنتاج - الإنتـاج والجدولـة - المشتريات - التسـويق ..)، والمخرجـات (المنتجـات بـالجودة

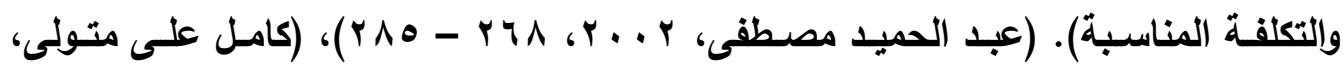
(1) 19 r- أهداف منهج تخطبط إدارة الإنتاج: بالاطلاع على منهج تخطيط وإدارة الإنتاج لطلاب الصف الثالث الثانوي الصناعي، أمكن

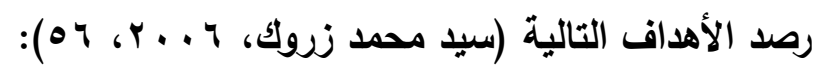


1- نشـر الـوعى بين طـلاب الصناعات الزخرفيـة بالمدرسـة الثانويـة الصناعية عن أهميـة

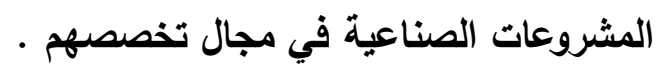
r - تحقيق التكامل بين المواد الدراسية (تكنولوجيا - مقايسات،... إلخ) بهدف اكتساب طلاب تهاب

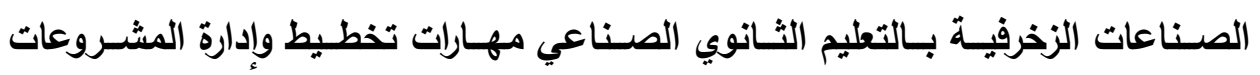
الصناعية في مجال تخصصهم . r - تنميـة مهـارات طـلاب تخصصـات الصــاعات الزخرفيـة بالمدرسـة الثانويـة الصــاعية

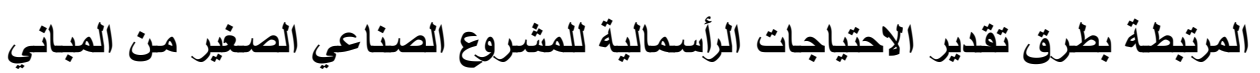

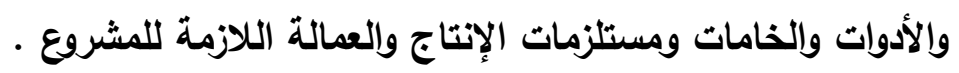

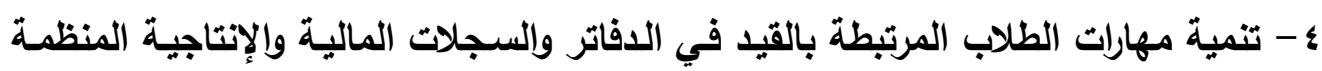

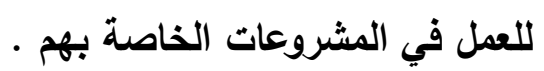
ه- تتميـة معرفة الطالب بأدوار الهيئات والمؤسسـات التي تسـاعد خريج المدرسـة الثانويـة

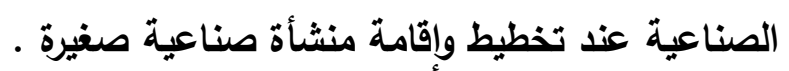

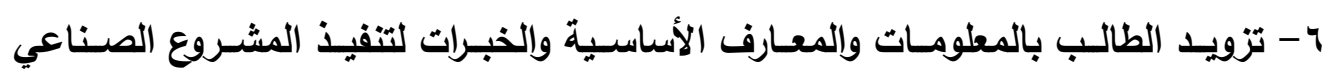
الصغير.

V- غرس الميول الصناعية فى نفس الطالب والوقوف على الحقائق الخاصة بها وتطويرها تكنولوجياً بجميع فروعها التي ترتبط ببعضها ارتباطاً وثيقاً.

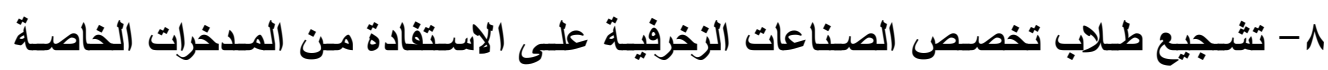
بالأسرة في تخطيط وإقامة مشروع إنتاجي أو خدمي يفيد المجتمع .

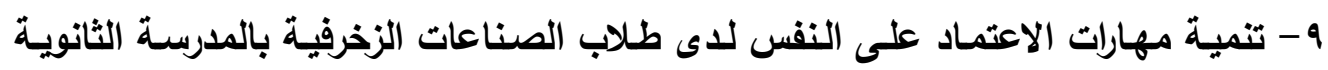

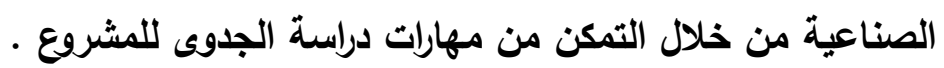

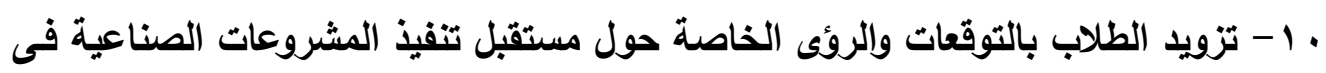

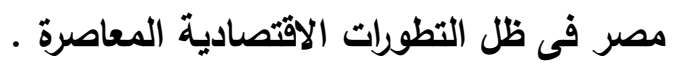

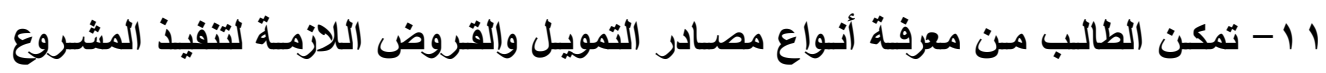
الصناعي الصغير الصن r ا - التدريب على حل المشكلات بطريقة إبداعية فى ظل التطورات الحادثة عند خروجه

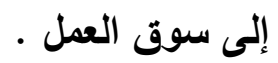


r ا - اكتسـاب القدرة على التعاملات المالية مـع المؤسسـات الخاصـة بالتمويل والمحاسبات

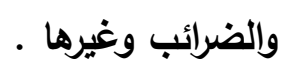

ويناءاً على ما سبق: تتضح أهمية وحتمية تنمية مفاهيم اقتصاد المعرفة وضرورة تضمينها

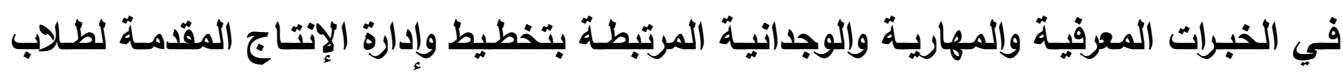
تخصص الزخرفة والإعلان بالمدرسة الثانوية الصناعية في ظل التحديات الاقتصادية والعلمية

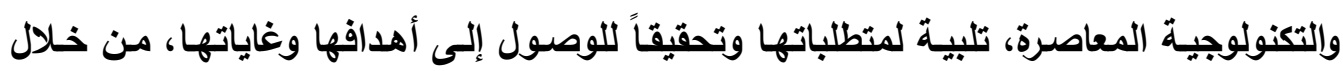
تدريب الطلاب في المواقف التعليمية المختلفة على ممارسـة مهام وواجبات مهنتهم بالكيفية والنوعية التي تحقق جودة الأداء والوصول بالمنتجات والخدمات المقدمة إلى الصورة المثلى،

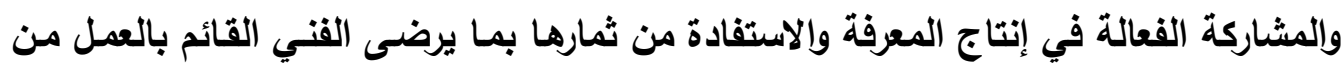
ناحية ويما يعود بالمنفعة على باقى أفراد المجتمع من ناحية أخرى ـ ويستفاد مما تقدم أيضاً:

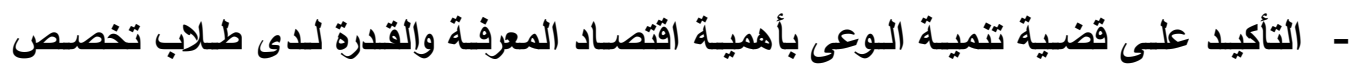

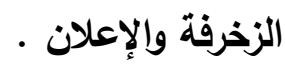
- المميزات المتعددة لتكامـل المـواد الدراسـية التي تحققها جوانـب التتعلم في المشـروعات الصناعية الصغيرة . - اكتسـاب القني للعديــ مـن الخبـرات الخاصـة بتقدير الاحتياجـات - التسـجيل في الدفاتر

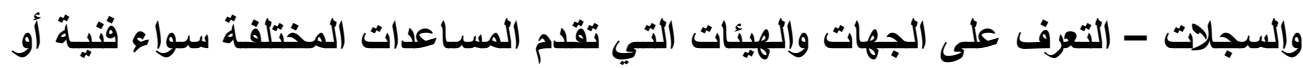
مادية . - تنمية الميول المهنية والصناعية لاى فنى الزخرفة والإعلان .

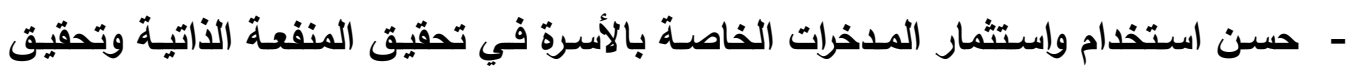

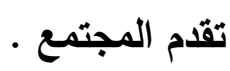
- اكتساب القني للعديد من القيم والاتجاهات الإيجابية نحو: تقدير العمل - استثمار الوقت

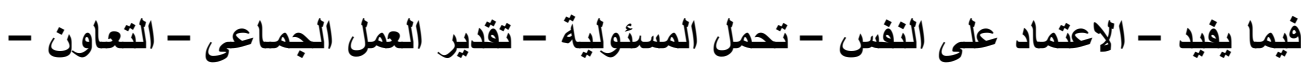

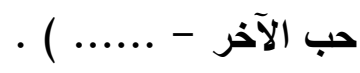
- اكتساب الفني للعديد من المهارات مثل: القدرة على التخطيط - صياغة الأهداف - الإعلان - التسويق - النظرة المستقبلية - القدرة على حل المشكلات بطريقة إبداعية - القدرة على منى 
التعامل مع الجهات المختلفة - تتفيذ الخطة - توزيع المهام والأدوار - المتابعة - التقويم المستمر لجميع خطوات ومراحل العمل) .

- مقد استفاد الباحث مما سبق ويحاول تطبيقه في جميع عناصر ومكونـات المنهج (الأهداف - المحتوى - الأنثطة التعليمية - طرق وإستراتيجيات التدريس وغيرها من المكونـات، بما وفاهي يساهم في تخريج الفني القادر على إنتاج المعرفة والاستفادة من ثمارها في تحقيق نهضتئه الشخصية وإلمجتمع بصفة عامة .

\section{ثانياً: اللدراسة الميلهانية:}

سارت إجراءات الدراسة الميدانية للبحث وفق الخطوات التالية:

1- تحديد مفاهيم اقتصاد المعرفة:

لما كان السؤال الأول من أسئلة البحث هو: مـائماد مفاهيم اقتصـاد المعرفة اللازمـة لطلاب تخصص الزخرفة والإعلان بالمدرسـة الثانويـة الصناعية ؟ وللإجابـة عن هذا السؤال ولتحديد تلك المفاهيم قام الباحث بالرجوع إلى مجموعة من المصادر، منها: الأدبيات والمراجع العلمية بالية

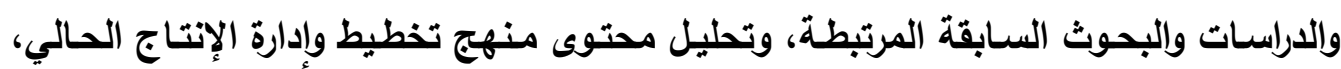
وقد أسفرت تلك الخطوة عن اشتقاق العديد من المفاهيم مثل دراسة الجدوى، اقتصاد المعرفة،

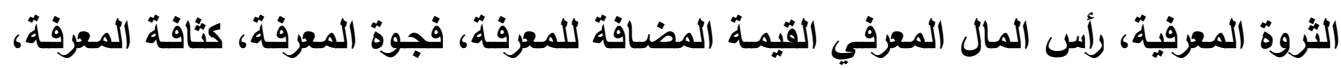
إضـافة إلى الكثير مـن القضـايا والمفـاهيم الفرعيـة ـ وتـم الاستعانة بالعديــ مـن الدراسـات

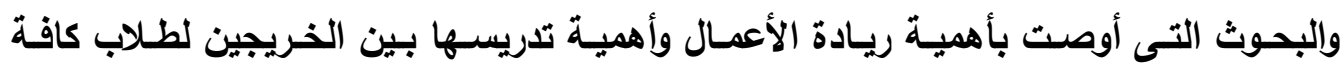

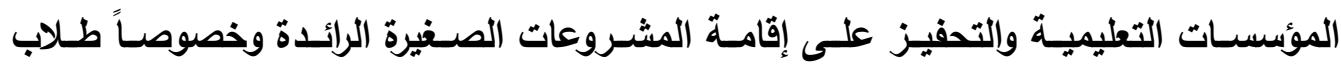
المدرسة الثانوية الصناعية فى ضوء توجهات ومرتكزات اقتصاد المعرفة ـ ويذلك تم التوصل لقائمة المفاهيم في صورتها الأولية، وتم عرضها على مجموعة من السـادة المحكمين الخبراء

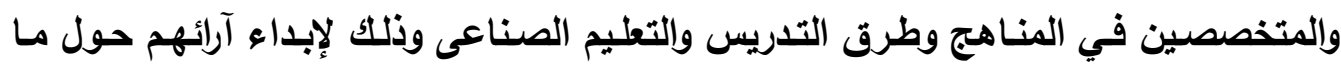
يلى 
- مدى دقة الصياغة اللغوية للمفاهيم الرئيسة . - مدى أهميـة المفاهيم الرئيسـة، ومدى أهمية المفاهيم والموضوعات الفرعيـة المتضمنة

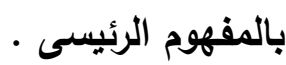
- مدى ملاعمة تلك المفاهيم لطلاب المدارس الثانوية الصناعية . - إضافة ما يرونه من مفاهيم أخرى ـ وقد اتفق معظم المحكمين على ما يلى:

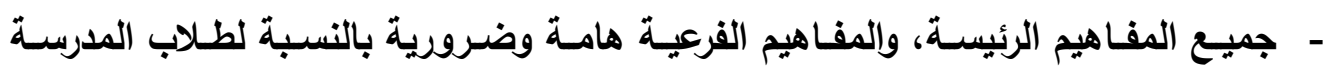

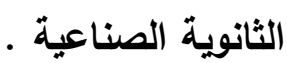
- ضرورة التبسيط في عرض بعض الموضوعات مثل دراسـات الجدوى، مؤشرات اقتصـاد

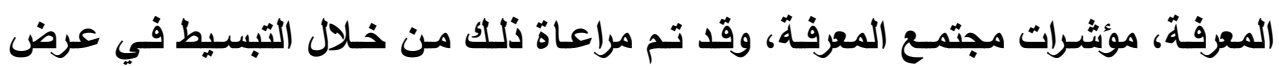

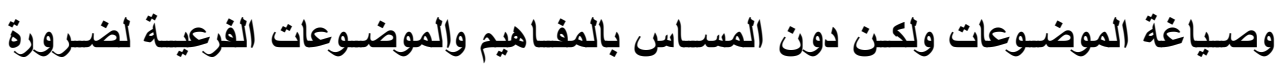
وأهمية دراستها ضمن المفهوم الرئيس . بعد ذلك تم حساب مستوى الالالة (كا؟ب) والنسبة المئوية لأهمية مفاهيم اقتصـاد المعرفة التي ينبغى تضمينها في المنهج المطور المقترح، أي حساب مستوى دلالة تكرارات الاستجابة لكل التل

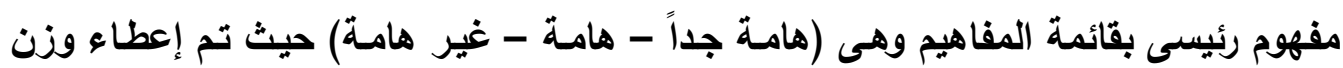

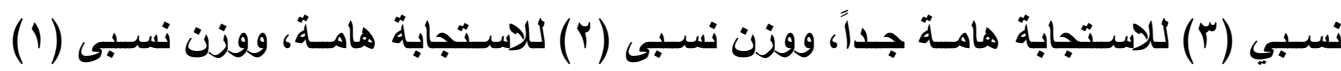
للاستجابة غير هامة، ويذلك تم التوصل لقائمة مفاهيم اقتصاد المعرفة التي ينبغي إكسابها وتنميتها لاى فنى الزخرفة والإعلان بالمدرسـة الثانويـة الصناعية في صورتها التها النهائية والتي التي اشتملت على (Yo) مفهوم رئيس يندرج تحتها ( I I ) مفهوم ومفاهيم وموضوعات فرعية .

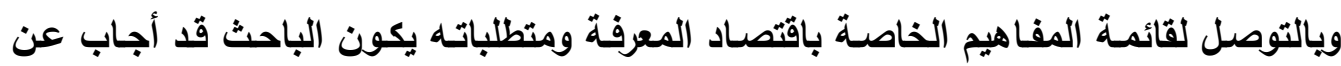
السؤال الأول من أسسئلة البحث ـ ويمكن توضيح تلكك المفاهيم الرئيسـة وإلفرعيـة المتضمنة

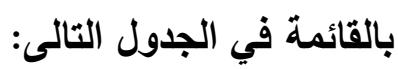




\section{جدول (r)}

قائمة المفاهيم الرئيسة والفرعية لاقتثاد المعاد المعرفة

\begin{tabular}{|c|c|c|}
\hline عدد المفاهيم الفزعية المتضمنة بها & المفاهيم الرئيسة & r \\
\hline- & المعرفة & 1 \\
\hline$r$ & أنماط المعرفة & $r$ \\
\hline$\varepsilon$ & مجتمع المعرفة & $r$ \\
\hline 0 & اقتصاد المعرفة & $\varepsilon$ \\
\hline- & الثروة المعرفية & 0 \\
\hline- & رأس المال المعرفى & 7 \\
\hline 7 & أبعاد اقتصاد المعرفة & $\mathrm{V}$ \\
\hline$\varepsilon$ & دورة حياة المعرفة & $\Lambda$ \\
\hline- & القيمة المضافة للمعرفة & 9 \\
\hline 0 & كثافة المعرفة & 1. \\
\hline- & فجوة المعرفة & 11 \\
\hline 7 & مؤشر ات فجوة المعرفة & Ir \\
\hline 0 & المحددات السياقية لاقتصاد المعرفة & 14 \\
\hline$\varepsilon$ & الأصول المعرفية & $1 \varepsilon$ \\
\hline 7 & مؤشرات قياس المعرفة & 10 \\
\hline $\mathrm{V}$ & محاور مؤشرات قياس اقتصاد المعرفة & 17 \\
\hline 17 & مؤشرات اقتصاد المعرفة & IV \\
\hline$r$ & دراسة الجدوى الاقتصادية & 11 \\
\hline 9 & دراسـة الجدوى القتية & 19 \\
\hline 14 & تقييم المشروعات الاستثمارية & $r$. \\
\hline 0 & الإدارة الإستراتيجية للأعمال & YI \\
\hline$\varepsilon$ & الموارد البشرية & rr \\
\hline 9 & النظام المحاسبى للمشروع & $r r$ \\
\hline 0 & الخطة التسويقية & $r \leqslant$ \\
\hline 11 & التمويل & ro \\
\hline 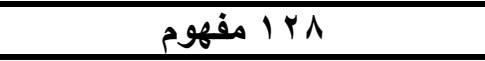 & \multicolumn{2}{|l|}{ إجمالي عدد المفاهيم = • مفهوم } \\
\hline
\end{tabular}

r- تحديد أسس بناء المنهج المطور:

تم تحديد أسس بناء المنهج المطور المقترح بالاعتماد على قائمة مفاهيم اقتصاد المعرفة التحى تم التوصل إلبها ومتطلباتها، والأدبيات والمراجع، ونتائج وتوصبات البحوث والدراسـات السابقة التى تم عرضها كما يلى 
أ- ظهور مفاهيم اقتصاد المعرفة، وكافة المفاهيم الفرعية المرتبطة بها ـ

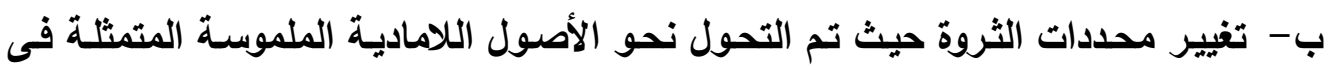

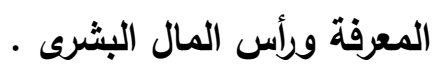

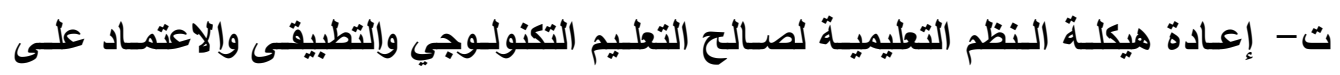
خريجي الكليات العلمية والتكنولوجية في تقليل الفجوة بين من يملك ومن لا يملك بين

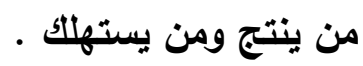
ث- التحول الملموس من توظيف وتفعيل المعلومات إلى توظيف وتفعيل المعرفة من خـلال

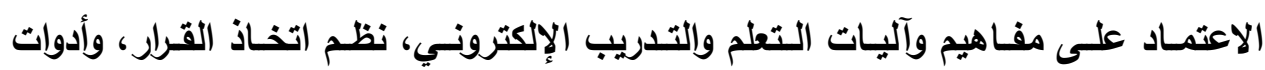

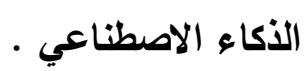

ج- عولمــة الإنتـاج والأسـواق والاعتمـاد على العماــة المـاهرة الخبيـرة بـنظم تكنولوجيـا

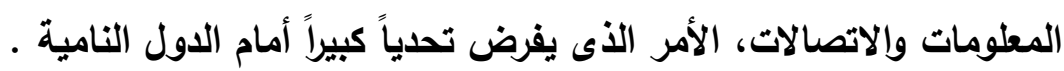
ح- طبيعة الأوضاع الاقتصادية وضرورة تثجيع المشروعات الصغيرة الرائدة .

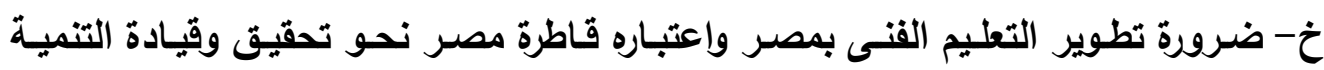
الاقتصادية . د- الوضع المتراجع لواقع تكنولوجيا المعلومـات والاتصالات ونظم توليد وتفعيل المعرفة فى

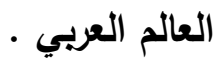
ذ- نتائج البحوث والدراسات التي توصي بضرورة تنمية المفاهيم الخاصة باقتصاد المعرفة .

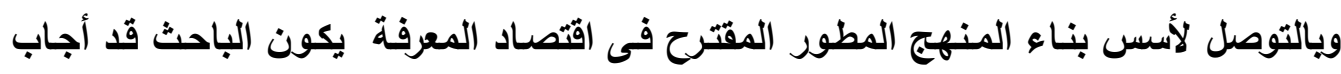

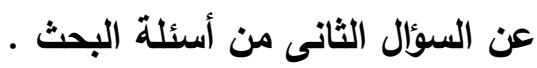
r- وضع الإطار العام لمنهج تخطيط وإدارة الإنتاج:

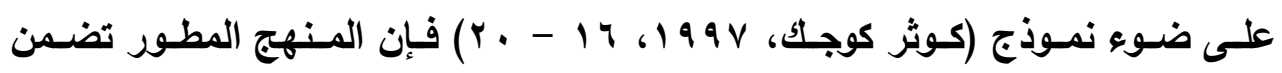
العناصر التالية: أ-منطلقات المنهج: عند بنـاء وتخطيط المنـاهج يراعى: فلسفة المجتمـع - طبيعة المـادة الدراسية - طبيعة المتعلم - تخطيط المنهج فى ضوء أسلوب النظم، وسوف يرد شرح للجوانب السابقة فيما 
1 - فلسفة المجتمع: يتسـم العصر الراهن بسـمة التغير السريع في كافة مجـالات الحياة الإنسانية، ويتأثر مسار وطبيعة هذا التغير بالنمو المتزايد لمعدلات الاكتشافات العلمية

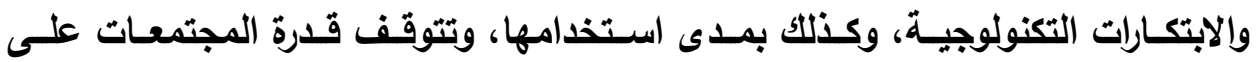
الصـمود في مواجهـة تحديات التغير والتطور على إمكاناتهـا البشـرية القـادرة على

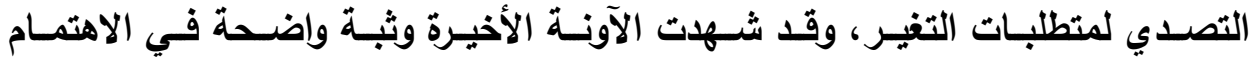

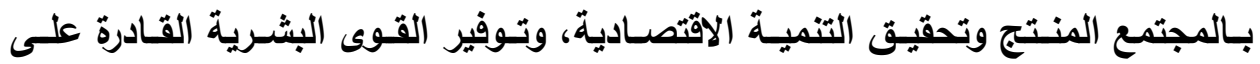
الإنتـاج، ولتحقيـق ذلـك لابــ مـن تـوافر عمالـة فنيـة عاليـة الأداء، وكـوادر متخصصـة

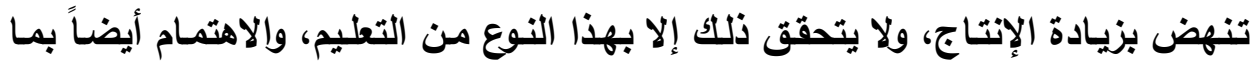

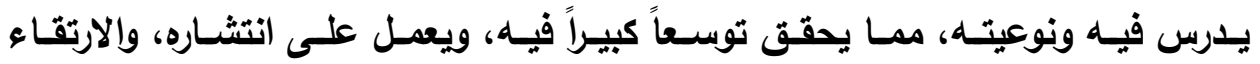
بمستواه. ץ- طبيعة المادة الدراسية: تعد مادة تخطيط وإدارة الإنتاج من أهم مواد التخصص الفنية،

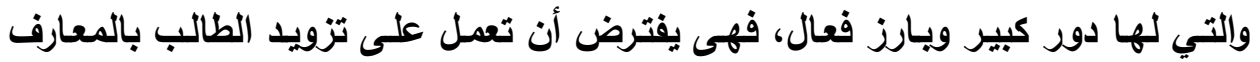
والخبرات اللازمة للإلمام بكيفية إقامة المشروعات الصناعية الصغيرة، وكيفية الحصول

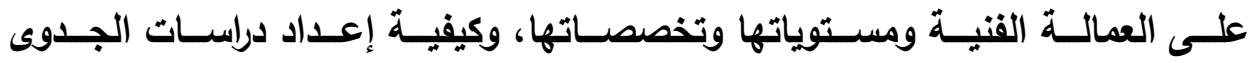
(الاقتصـادية - التمويليـة - التسويقية)، وتعريف الطالب بالجهات الداعمـة لمثل هذه

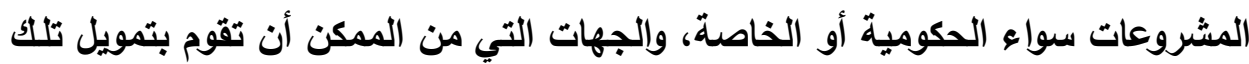
المشروعات، وكيفية التسجيل في الدفاتر ، وكيفية تكوين فرق العمل، وتوزيع الأدوار

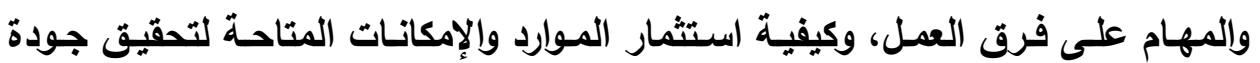
الإنتاج، ومن ثم تحقيق الربح والفائدة المادية على صاحب المشروع بل وعلى المجتمع بصفة عامـة، ممـا يسـاهم في تحقيق نهضـة المجتمـع في كافـة المجـالات الاقتصـادية والاجتماعيـة وغيرهـا ـ ويلاحظ أن مثل هذه المـادة يتم تدريسـها لطلاب الصف الثالث فقط بواقع (حصتان في الأسبوع)، وقد اقترح الباحث بعد إضافة موضوع اقتصاد المعرفة بمتطلباته، أن يتم تدريس هذا المنهج في صورة مقرين دراسيين، مقرر للصف الثانى،

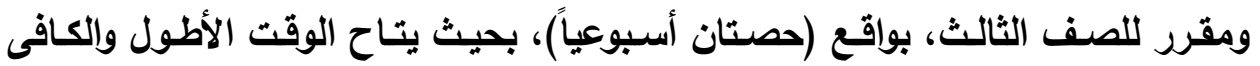
للطلاب لاراسة هذا المنهج واكتساب خبراته النظرية والتطبيقية . 
r- طبيعة المتعلم: تمثل أعمار الطلاب الذى يقدم لهم المنهج المقترح، مرحلة المراهقة،

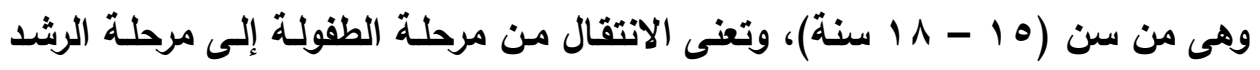

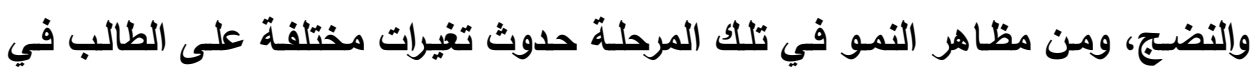

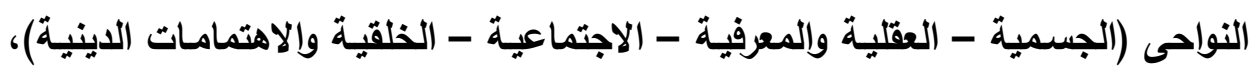

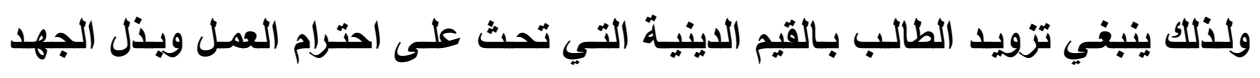

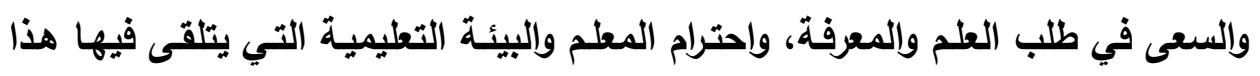

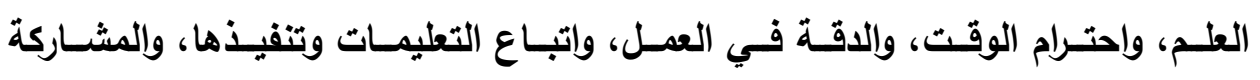

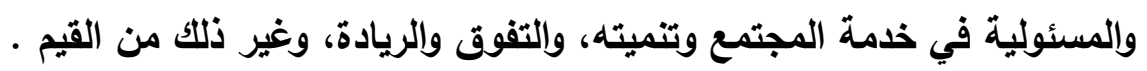

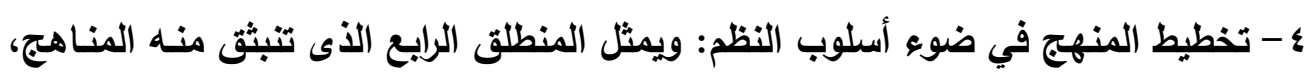
ولاعتبار المنهج كنظام لابد من التركيز على ثلاثة أمور أساسية، أولها التكامل والترابط التيط

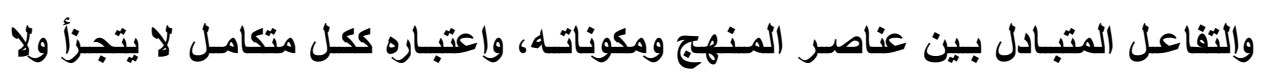

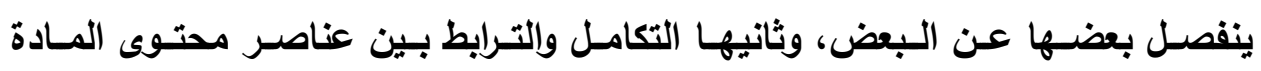

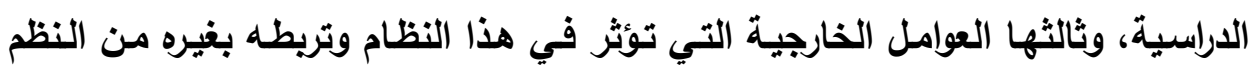

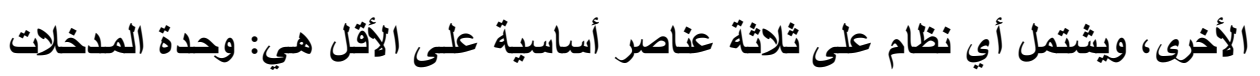

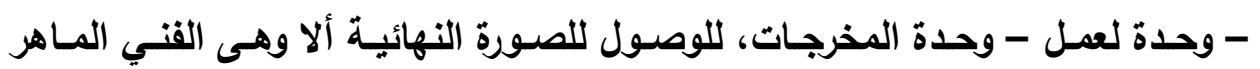

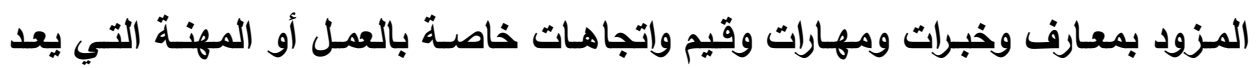

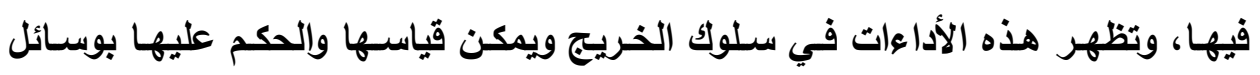
محدةة، للتأكد من مدى تحقيق الأهداف المنثودة .

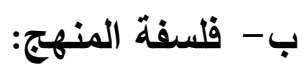
تتمثل فلسفة هذا المنهج المطور في: إعداد فنى الزخرفة والإعلان بالمدرسة الثانوية

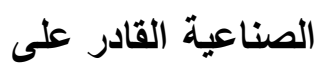
استيعاب مفاهيم اقتصاد المعرفة ومتطلباتها، والمساهمة بوعى في إنتاج المعرفة العلمية والتكنولوجية التي ترتبط بمجالات تخصصه، الأمر الأى يساهم بفاعلية في تحقيق نهضية

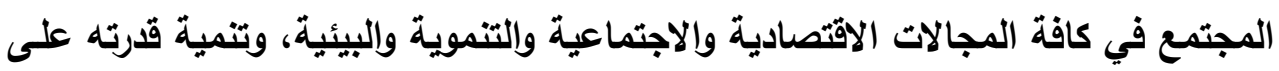
مواجهة التحديات العالمية المعاصرة وحسن وجودة التعامل معها. 
ت- الأسس التي يقوم عليها:

فـ ضـوء مـا سـبق يمكن تحديد الأسس العلميـة التى يمكن الاستتناد إليها عند بنـاء المنهج، وهى كما يالى: 1 - مفاهيم اقتصاد المعرفة مكتسبة تنمو بالممارسـة والتدريب، وأنهـ كلمـا نمت هذه المفاهيم لـــ المـتعلم ســاعده ذلـك على التحـرك بـوعى فـي إنتـاج المعرفـة وحسـن اسـتثمارها

وتوظيفها.

r - اكتساب وتتمية مفاهيم اقتصاد المعرفة عملية علمية يمكن أن تتم إذا ما توفرت الفرصة

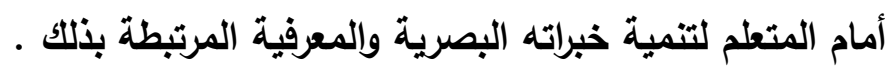
r- ضرورة الاهتمام بجوانب الخبرات المرتبطة باقتصاد المعرفة ومتطلباتها لاى المتعلم . ع - مراعـاة الفروق الفرديـة بين المتعلمين والتـى تتمثل فـى اختلاف خصائصـهم وميـولهم وأنماط تعلمهم مرأعاه ه- الاعتماد على إيجابية المتعلم ونشـاطه، حيث أن الخبرة التى يكتسبها المتعلم من خلال العمل والنشاط تكون أبقى أثراً وأكثر فائدة . 1- الاهتمـام بتتميـة جوانب نمو المتعلم المعرفيـة والمهاريـة والوجداتيـة فـى شـول وتكامـل

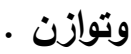
V- تـوفير بيئة تعلـم تتسـم بالمرونـة وإلتــوع مـن حيث الطرق والاسـتراتيجيات، والأنشـطة

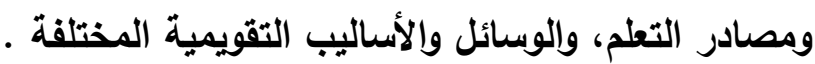
1- اكتسـاب الطالب قيم إيجابية (حب العمل - العمل التعاونى - حريـة إبداء الرأى واحترام

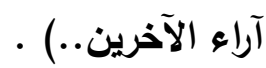
9- إثـارة دافعيـة الطالب نحـو البحث والاستقصـاء وجمـع المعلومـات المرتبطـة بموضـوعات - المنهج • - - تتمية الوعى بالمخاطر والتحديات المعاصرة لاى الطلاب .

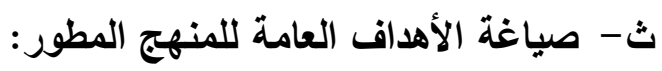
يعتبر تحديد الأهداف وصياغتها مـن الأمسور بالغـة الأهميـة في العمل التريـوي بصفة

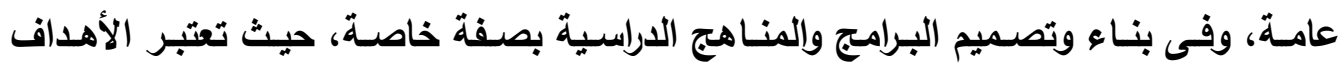
المكون الأول والرئيسى عند تصميم البرامج والمناهج الدراسية، إذ من خلالها يتم توجيه كافة 
الجهود التربويـة، وتنظيم وصياغة بـاقي مكونـات البرامج والمنـاهج الدراسية مـن محتوى،

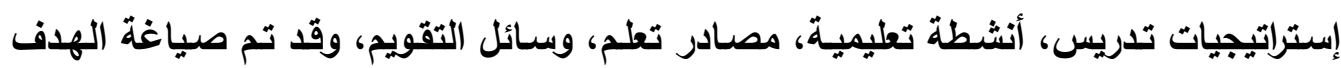

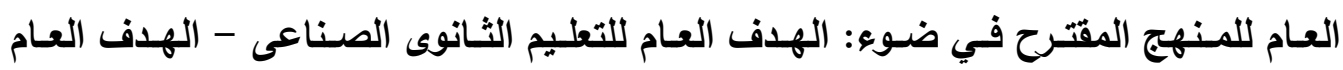

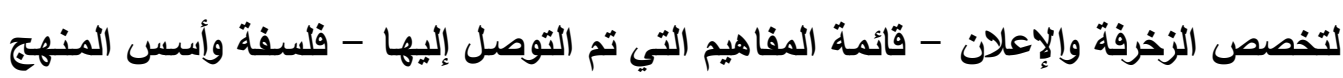
المطور المقترح، ويذلك تم التوصل للهذف العام للمنهج المطور المقترح فى تخطيط وإدارة الإنتاج كالتالي:

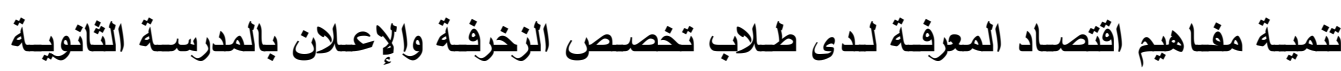
الصناعية مـن خـلال منهج تخطيط وإدارة الإنتاج المقترح ـ وينبثق مـن هذا الهدف العـام

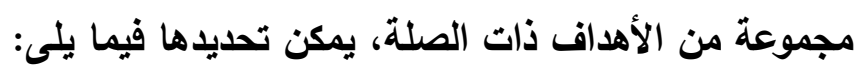
1 - تعريف الطالب بمفاهيم المعرفة، اقتصاد المعرفة، والمقومات الأساسية لها. r - اكتساب الطالب القدرة على تقييم المشروعات الاستثمارية . r- يوضيح الطالب الأهمية الاقتصادية للمعرفة، ودور الموارد البشرية في استثمارها . ع - تعريف الطالب بالمصادر المختلفة للحصول على الدعم المادى والتمويل . ه- يحد الطالب ملامح الإدارة الإستراتيجية للأعمال .

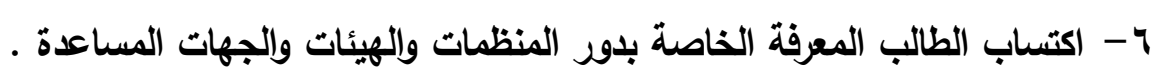
- V تعرف كيفية عمل دراسة الجدوى الاقتصادية وإلقنية وإلتسويقية . ^- اكتساب الطالب أخلاقيات المهنة فى المجال الصناعى، (الصدق - الأمانة - الصبر..). 9 - تتمية العديد من القيم للدى الطالب مثل: حب العمل - الدقة - التعاون مـع الآخرين تحمل المسئولية. ـ 1 - تنميـة الاتجاهـات الإيجابيـة لدى الطالب نحو نفسـه وزملائه والبيئة والمجتمـع بصفة عامة . تاند ج- عناصر المنهج المطور: ويشمل المنهج العناصر التالية: 


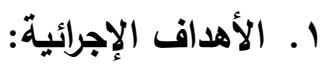

فى ضوء الأهداف العامة السابقة قام الباحث بصياغة الأهداف الإجرائية لكل وحدة من وحدات المنهج المقترح، وراعى فيها التنوع، لتشمل جوانب النمو المختلفة، ولتناسب قدرات الأبهات وميول الطلاب، كما راعى فيها معايير الأهداف التريسية الجيدة ومنها: التدرج في صياغتها

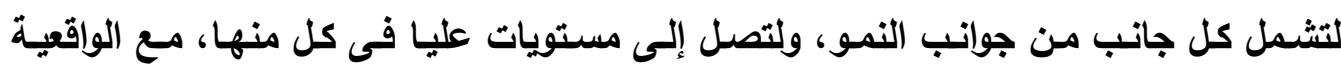
والوضوح فى صياغتها والقدرة على تحقيقها، وقدرة الطالب على تنفيذ الأداعت المتضمنة بها

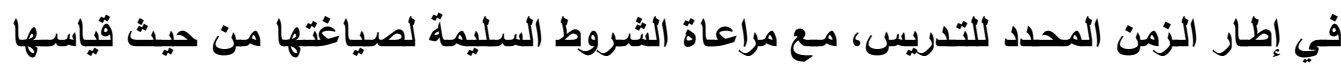

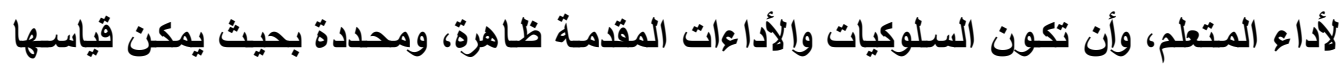

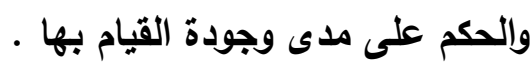

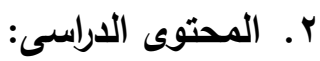

يقصد بمحتوى المنهج تلك المفـاهيم والموضـوعات والقضـايا التى وقع عليها الاختيار

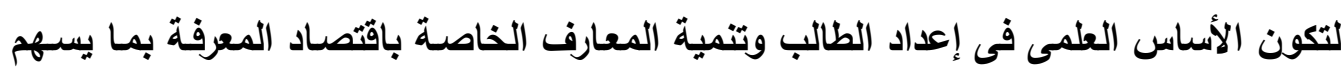
فى اكتسابها وتتميتها لايه، لذا فقد قام الباحث بالرجوع إلى مجموعة من المصادر، وهى: - الرسائل العلمية والاراسات والبحوث التي تتاولت موضوعاتها مفاهيم اقتصاد المعرفة .

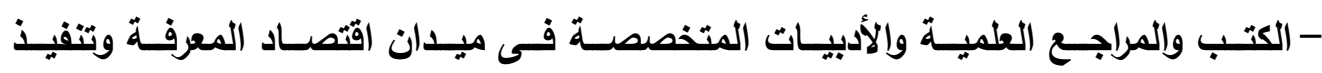

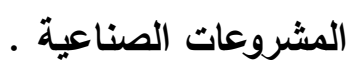

وروعي فـى المحتوى أن يكون بـه قدر مـن المرونـة، بحيث يـتم حـف أو إضـافة بعض

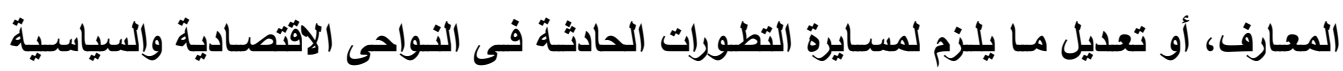

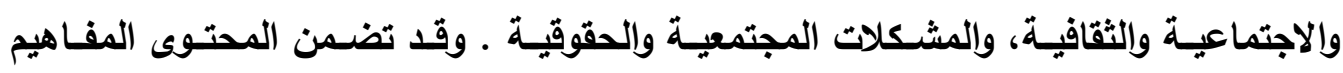
التالية:

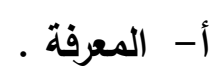

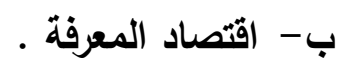

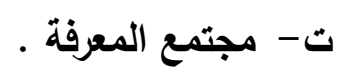

ث- مؤثرات اقتصاد المعرفة . مجئم

ج- دراسة الجدوى الاقتصادية والقنية . ح- تقييم المشروعات الاستثمارية . 


\section{خ- الإدارة الإستراتيجية لنأعمال . \\ د - دراسة الجدوى التسويقية . \\ ذ- الأظام المحاسبى ومصادر تمويل المشروعات . \\ ر- تخطيط الموارد البشرية .}

تم الاستفادة من المفاهيم المرتبطة باقتصساد المعرفة المستخلصة من الأدبيات والبحوث والدراسات السابقة، والمفاهيم المستخلصة من تحليل محتوى المنهج الحالي، وتم توزيعهما على عامين دراسيين وهو ما يقترحه الباحث، بحيث يقدم المنهج في صورة مقررين دراسيين، مقـر في الصـف الثـانى، وآخر في الصـف الثالث، بصـورة متدرجـة ويراعى فيها التـوازن والتكامل والثمول والتتابع، ويمكن توضيح ذلك في الجدول التالى:

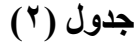

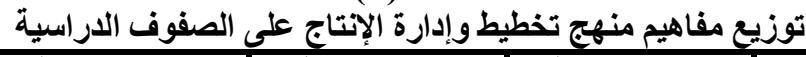

\begin{tabular}{|c|c|c|c|c|c|}
\hline الوحدة الخامسة & الوحدة الرابعة & الوحدة الثالثة & الوحدة الثانية & الوحدة الأولى & الصف \\
\hline 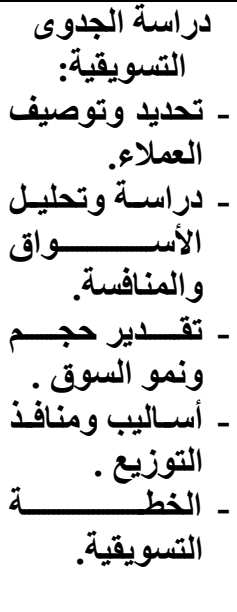 & 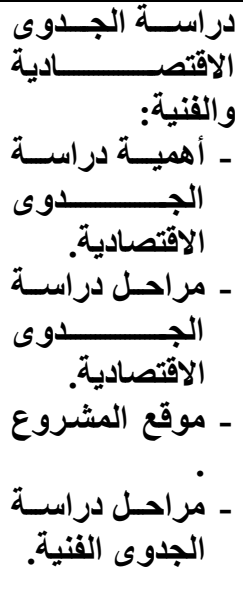 & ـ ـ ـ ـ الاسترزاتيجية & ـ ــ البشيط المواردة & 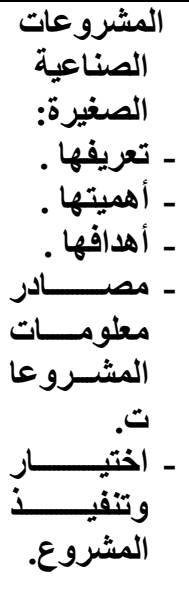 & الثانى \\
\hline 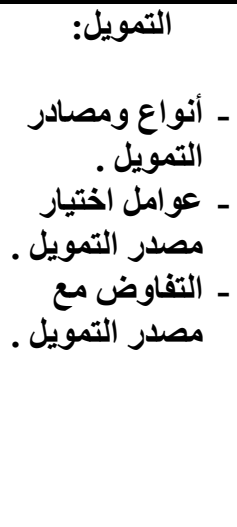 & - الاستثرئمارية: & ـ اللمشرو المحاسبى & 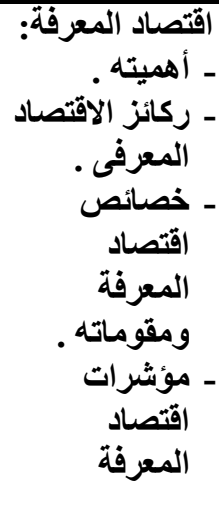 & - المعرفةة & الثالث \\
\hline
\end{tabular}


على أن يتم تدريس كل مقرر في الفصل الأول من كل عام، ومن الممكن أن تكون هناك

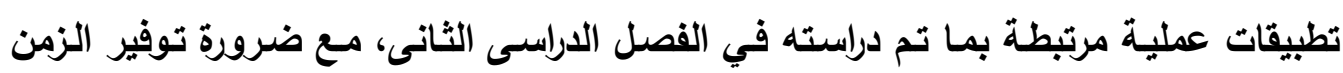

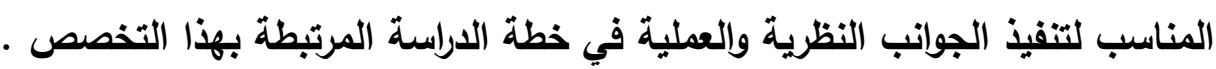

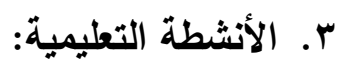
اختار الباحث الأنشطة التعليمية التى تناسب مستوى الطلاب، وراعى فيها التنوع بمـا يلائم الأهداف والمحتوى الدراسى فى كل وحدة تدريسية. وقد اشتملت على أنشطة داخل الفصل

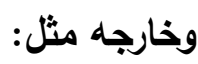

• تتفيذ الأعمال والمهام التى تتطلبها الوحدة التى يتم دراستها.

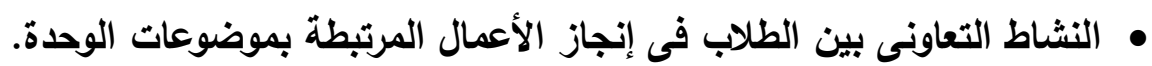

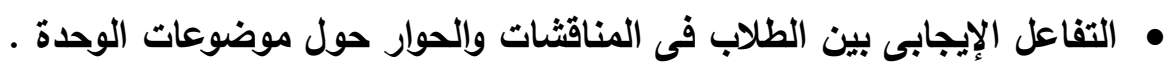

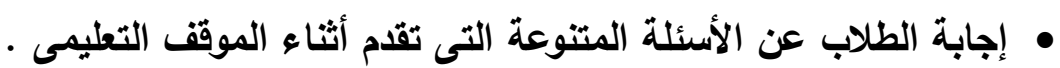
• كتابة بحوث وتقارير بصورة فردية، أو جماعية مرتبطة بموضوعات الوحدة.

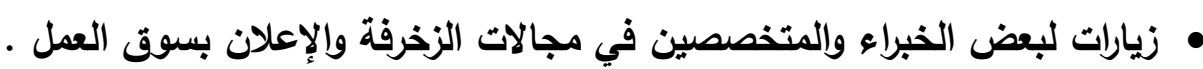

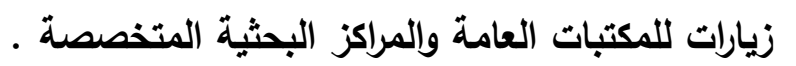

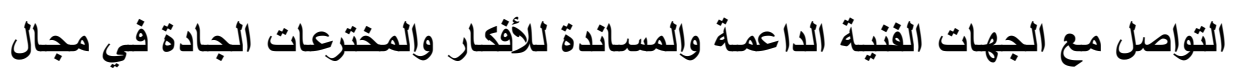

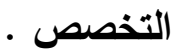

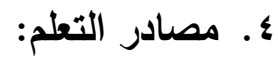
تعتبر من أهم العناصر التى تجعل من الموقف التعليمى أكثر جاذبيـة وتشويقاً للمتعلم

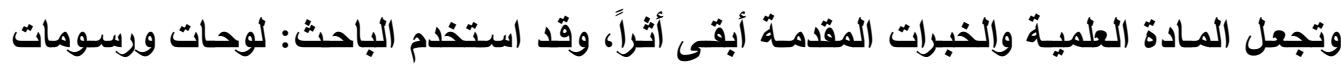

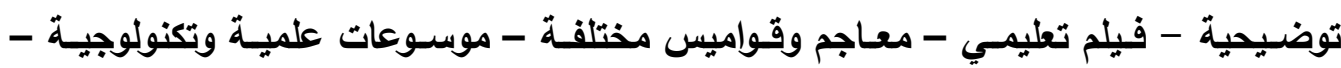

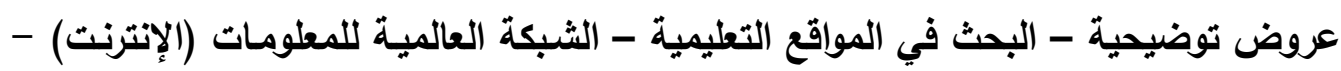
الموضوعات الدراسية - الكتب والأدبيات والمراجع الحديثة . هـ إستراتيجيات التدريس: استخدم الباحث مجموعـة مـن طرق التـريس التـى يـرى مـن وجهـة نظره أنها تناسب

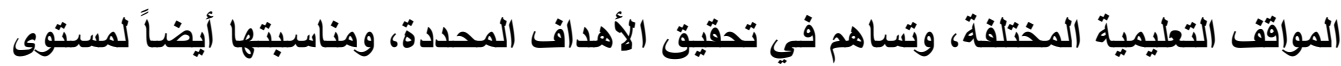
وقرات الطلاب، وإتخدمها فى صياغة عدة استراتيجيات وفقاً لمنطلبات وطبيعة كل موقف، وني، 
ومنهـا مـا يلى: (المحاضرة الفعالـة - الحهور والمناقشـة - العصف الذهنى - الاستقصـاء العمل فى مجموعات - البيان العملى - حل المشكلات).

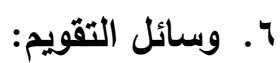

استخـــدم الباحث مجموعة من وسـائل التقويم المتنوعة، لقيـاس مدى اكتسـاب الطلاب للمفاهيم والمهارات والقيم والاتجاهـات المتضمنة بكل وحدة من وحدات المنهج المطور المقترح؛ ففى الجانب

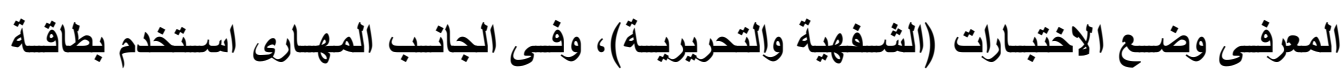
الملاحظة لتقويم الأداء المهارى للطلاب أثناء تنفيذ خطوات العمل، واستخدم مقاييس لتقويم

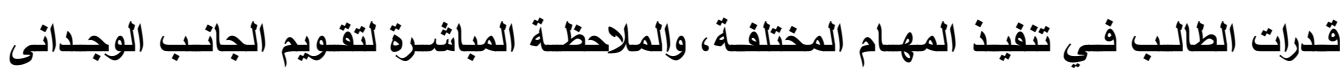
المتضمن - عـرض الصـورة المبائيـة للإطـار العـام لعناصـر المــهج المطـور علـى السـادة الخبـراء

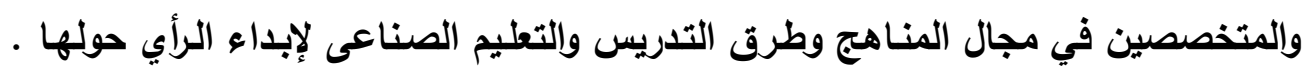
وتعديل مـا يلـزم فـي ضـوء المقترحسات المقدمـة، ومـن ثـم التوصـل إلى الصـورة النهائيـة للانهج المطور. - ويالتوصل إلى وضع الإطار العام للمنهج المطور في تخطيط وإدارة الإتتاج، يكون الباحث

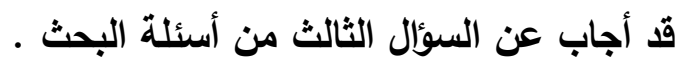
ع - قياس فاعلية وحدتين من وحدات المنهج المطور:

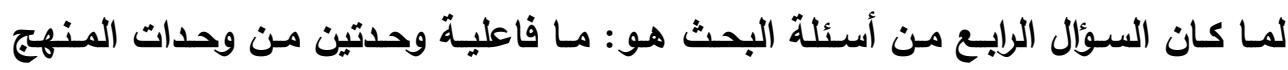
المطور في تنمية مفاهيم اقتصاد المعرفة لدى طلاب تخصص الزخرفة والإعلان بالمدرسـة الثانوية الصناعية ـ لذا فقد تم اختيار وحدتى (المعرفة)، (اقتصاد المعرفة) لتدريسهما وقياس لتهاس

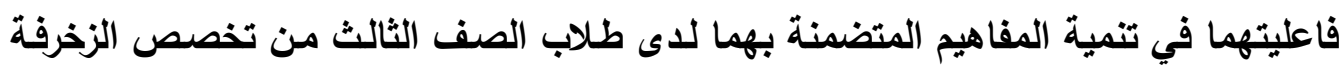
والإعلان بالمدرسة الثانوية الصناعية، للأسباب التالية: مبررات اختيار الوحدة الأولى (المعرفة) والوحدة الثانية (اقتصاد المعرفة):

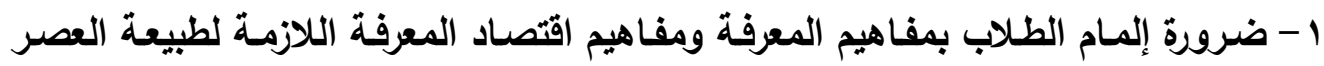
- الحالي r - طبيعة التحولات الاقتصادية المعاصرة والتتاكيد على التحول نحو مجتمعات المعرفة . 
r - جميع المقررات الدراسية تخلو من أى تعريف لاقتصاد المعرفة على الرغم من أهميته . ع - ارتباط ركائز الاقتصاد المعرفة من التطور التكنولوجى، الابداع والابتكار بريادة الأعمال . ه - تأكيد نتائج الاراسات بأهمية تدريس مفاهيم اقتصاد المعرفة للطلاب في مراحل التعليم المختلفة . تاكل

إجراعات إعداد الوحدة الأولى (المعرفة) :

تضمنت الوحدة الأولى العناصر التالية:

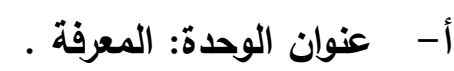

تخير الباحث هذا العنوان لارتباطه بموضوع الوحدة والذى يتناول جوانب مختلفة لهذا

$$
\text { ب- المفهوم • مقدمة: }
$$

تتــاول هذه الوحدة موضـوع المعرفة، حيث نتعرف مـن خلالهـا على بعض المفـاهيم والمعلومات المرتبطة مثل (أنماط المعرفة - مجتمع المعرفة - الثروة المعرفية - رأس المـال

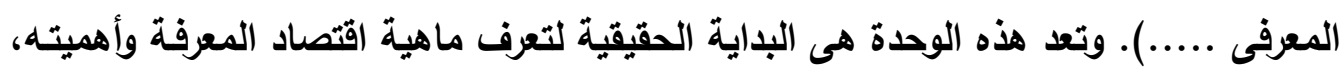
ويستفيد الطالب من هذه الخبرات سواء داخل المدرسة أو فى سوق العمل، حيث يكتسب منها الأساس العلمى السليم لما يقوم به من أعمال مرتبطة بتخصصه ليس هذا لذا فحسب بل فل وإكسابه

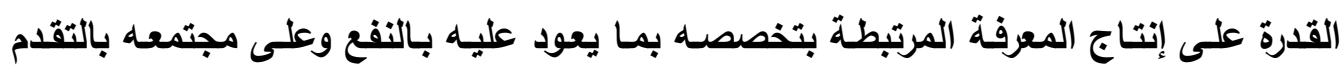
والرقى في شتى مجالات الحياة الاقتصادية والاجتماعية وغيرها . ت- الأهداف الإجرائية:

فى نهاية تدريس هذه الوحدة من المتوقع أن يصبح كل طالب قادراً على أن:

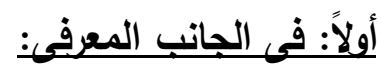

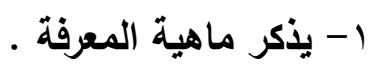

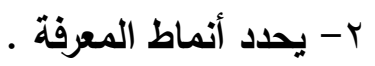

$$
\begin{aligned}
& \text { r- يفسر نمطى المعرفة (الصريحة - الضمنية) . } \\
& \text { ع - يكتثف الفرق بين نمطى المعرفة . } \\
& \text { 0- يحدد أهم ملامح مجتمع المعرفة . } \\
& \text { 7- يبين خصائص مجتمع المعرفة . }
\end{aligned}
$$


V- يقارن بين مجتمع المعلومات ومجتمع المعرفة من حيث أهم الملامح .

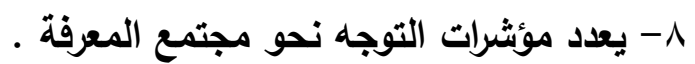

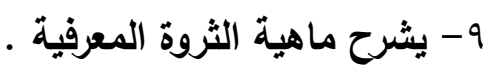

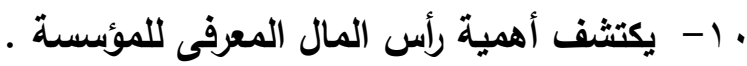

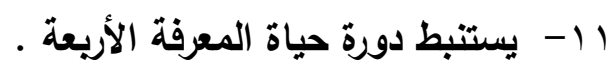

r ا- يشرح ماهية كثافة المعرفة .

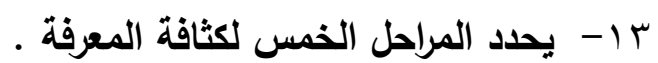

ع ا- يفسر الأسباب الحقيقية لفجوة المعرفة .

10

7 ا 1 - يعدد ست مؤثرات لقياس فجوة المعرفة .

IV

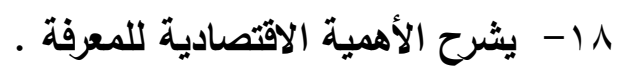

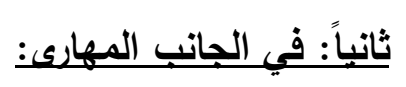

1 - يلاحظ بعناية الرسومات التوضيحية والكروكيات المرتبطة بموضوع الوحدة .

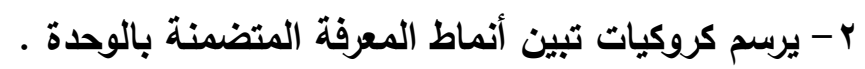

r- يكتب بحثاً يتناول بعض مفاهيم الوحدة مراعياً الشروط الصحيحة والجيدة للكتابة.

ثالثاً: في الجاتب الوحدانحى:

1- يهتم بالقراءة حول موضوع المعرفة .

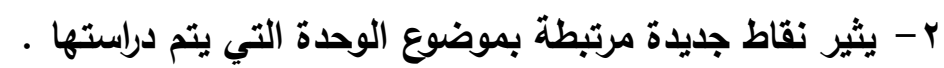

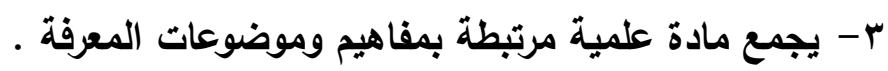

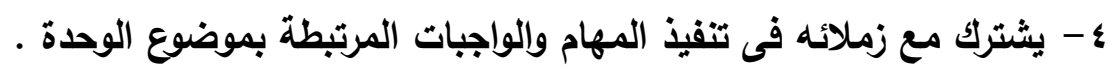

ه- يبادر بحل الأسئلة المرتبطة بموضوع الوحدة ووضعها في ملفئه الخاص. 
ث - المحتوى الدراسي:

تضمن محتوى الوحدة العناصر التالية:

(مفهوم المعرفة - أنماط المعرفة - مجتمع المعرفة - الثروة المعرفية - رأس المـال المعرفى - دورة حياة المعرفة - كثافة المعرفة - فجوة المعرفة - مؤثثرات فجوة المعرفة - المعرفة

وخصائصها الاقتصادية - المعرفة وأهميتها الاقتصادية) .

ج- الأنشطة التعليمية:

استخلم الباحث مجموعـة مـن الأنشطة التعليميـة التى يـرى مناسبتها لتحقيـق أهداف الوحدة، منها أنشطة فردية، وأنشطة جماعية، تم تنفيذها داخل الفصل أو خارج نطاق الفصل، وقد تمثلت فى: الحوار والمناقشـة مـع الطلاب حول موضوعات الوحدة، الاهتمـام بجمـع مـادة

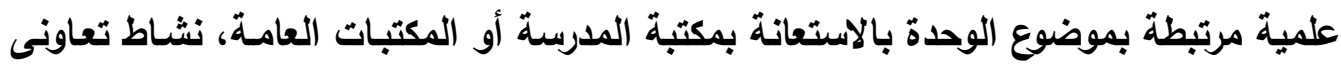
بين الطلاب لإنجاز الأعمـال المختلفة التى تتطلبها جوانب التعليم فـى الوحدة، والمشـاركة الإيجابية فى الإجابـة عن الأسئلة التى تطرح على مجموعات العمل، والإجابة عن الأسئلة

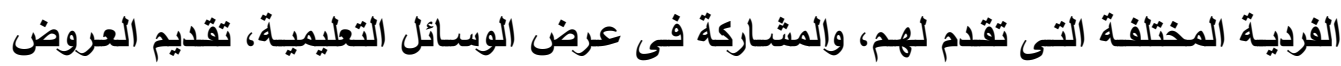
البيانية والتوضيحية، إلى غير ذلك من الأنثطة .

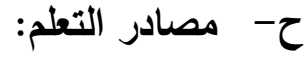

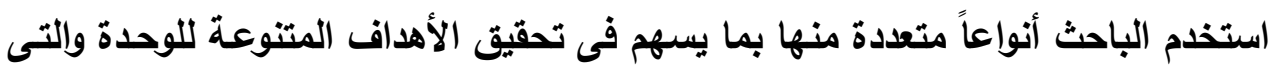

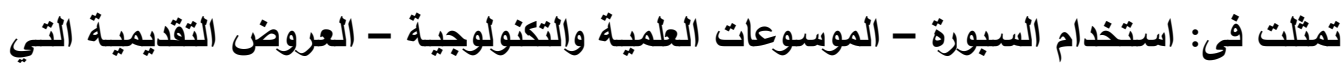

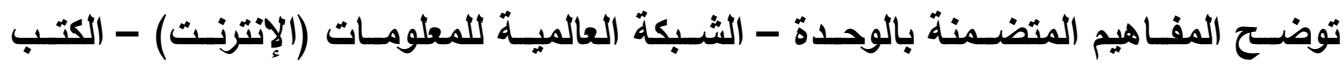
والأدبيات المرتبطة بموضوع الوحدة ـ إلى غير ذلك من الوسائل التى اتيح للباحث استخدامها

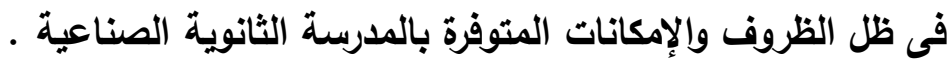
خ - استراتيجيات التدريس: اهتم الباحث باختيار استراتيجيات وأساليب تدريس متنوعة تناسب تحقيق أهداف الوحدة،

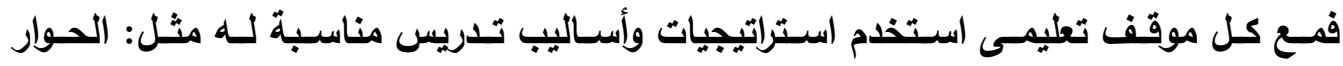
والمناقشة عند عرض وتقديم موضوع جديد، وحينما يتطلب الموقف أن يعمل كل طالب بصورة فرديـة استخدم أسـلوب العمـل الفردى، وحينمـا يكون هدف الدرس أن يتعـاون الطـلاب فيمـا بينهم، لإنجاز الأعمال المطلوية منهم استخدم أسلوب العمل فى مجموعات صغيرة، ولم يخل 
موقف من هذه المواقف من استخدام مهارات تدريس أخرى مثل: التهيئة المكانية واللفظية

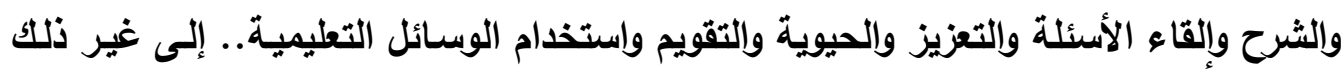

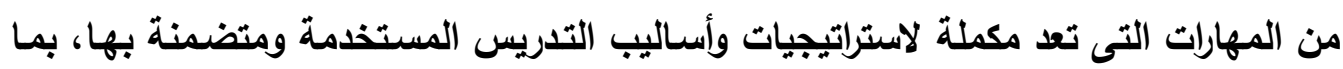

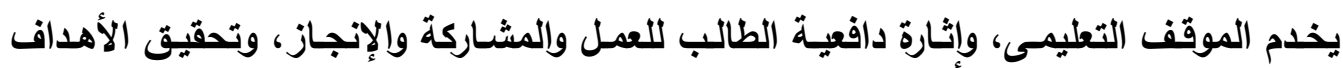
المطلوية فى شتى جواتب النمو.

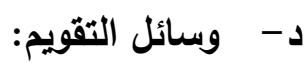

تم تقويم الوحدة فى ضوء الأهداف المحددة للتدريس، وفقاً للمراحل التالية: - التقويم القبلى Initiative Evaluation، وتم قبل عرض موضوع الوحدة بهدف تعرف مستوى الطلاب، وتحديد نقطة البداية الصحيحة للتعلم، وقد اتضح ذلك من خلال إجابتهم

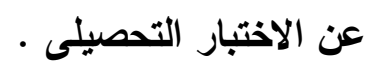
- التقويم التكـوينى Formative Evaluation، وتـم ذلـــ بعـ شـرح كـل مفهوم مسن مفاهيمها وفى نهاية كل درس من دروس الوحدة، بهدف جذب انتباه الطلاب من ناحية،

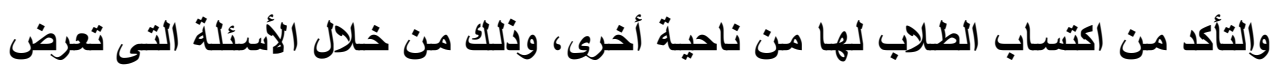

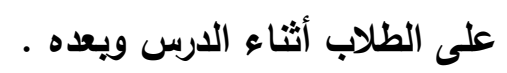

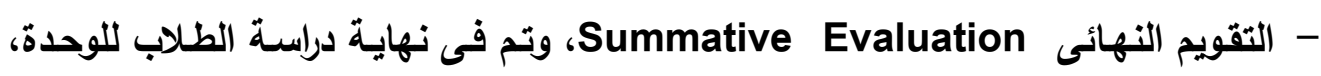
حيث تم تقويم معلومات وقيم واتجاهات الطلاب من خلال إجابتهم عن الاختبار البعدى الأى استخدم لقياس مدى اكتسابهم للمفاهيم المتضمنة بالوحدة . ذ- - الزمن اللازم للتدريس:

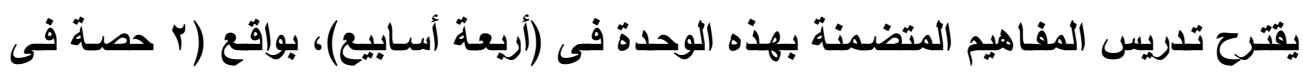
الأسبوع)، والجدول التالى يبين تخطيط دروس الوحدة الأولى والزمن اللازم للتدريس: 


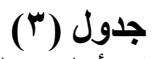

توزيع دروس الوحدة الأولى والزمن اللازم للتدريس

\begin{tabular}{|c|c|c|c|c|}
\hline الحصص & عنوان الارس & الدرس & التاريخ & الأسبوع \\
\hline$r$ & (مفهوم المعرفة _ أنمعاط المعرفة _ مجتمع & الأول ال & & الأول ال \\
\hline$r$ & 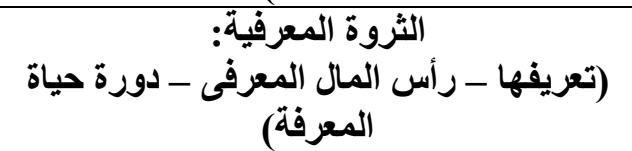 & الثانى الثى & & الثانى الثى \\
\hline$r$ & (تعريفها - فجوة المعرفة - مثوفة مؤشرات فجوة & 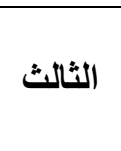 & & 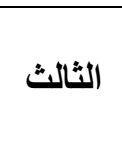 \\
\hline$r$ & (خصائصها الاقتصادية _ أهميتها الاقتصادية) . & الرابع & & 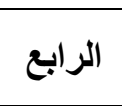 \\
\hline & إجمالي عدد الحصص = & \multicolumn{3}{|c|}{ إجمالي عدد الأسابيع = ع } \\
\hline
\end{tabular}

ويلاحظ مـن الجدول أن كل درس من دروس الوحدة يتم تناولـه مـن خـلال جوانبـه المختلفـة النظريـة والتطبيقيـة بطريقـة متكاملـة، بحيث يـؤدى في النهايـة إلـى إتقان الطالب للمفاهيم المتضمنة بالسرعة، واللدقة المطلوية . اجراءوات إعداد الوحلدة الثانية ( اقتصاد المعرفة) : تضمنت الوحدة الثانية العناصر التالية: أ- عنوان الوحدة: اقتصاد المعرفة . تخيز الباحث هذا العنوان لارتباطه بموضوع الوحدة والذى يتناول جوانب مختلفة لهـا

$$
\text { ب- مقدمةمة • }
$$

تتناول هذه الوحدة موضوع اقتصاد المعرفة، حيث نتعرف من خلالها على بعض المفاهيم والمعلومات المرتبطة مثل (مفهوم اقتصاد المعرفة - القيمة المضـافة للمعرفة - أبعاد اقتصاد المعرفية - المحدات السياقية لاقتصاد المعرفة - الأصول المعرفية .....). وتعد هذه الوحدة

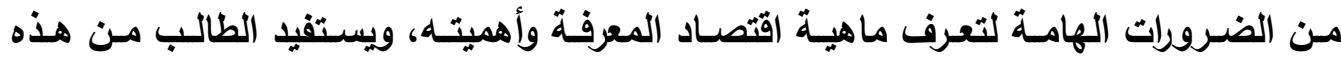
الخبرات سواء داخل المدرسة أو فى سوق العمل، حيث يكتسب منها الأسـاس العلمى السليم لمـا يقوم بـه من أعمال مرتبطة بتخصصه،، ليس هذا فحسب بل وإكسابه القدرة على إنتاج 
المعرفة المرتبطة بتخصصـه بمـا يعود عليه بـالنفع وعلى مجتمعـه بالتقدم والرقى في شتى

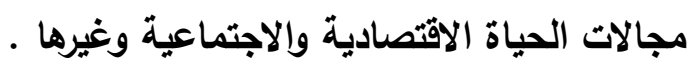

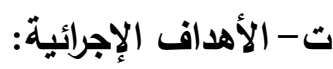
فى نهاية تدريس هذه الوحدة من المتوقع أن يصبح كل طالب قادراً على أن: أولاً: في الجانب المعرفحي: 1- يعرف ماهية اقتصاد المعرفة .

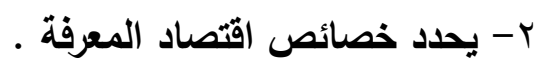
r- يستتتج ركائز اقتصاد المعرفة . ع- يقارن بين اقتصاد المعرفة والاقتصاد المبنى على المعرفة . ه- يميز بين الاقتصاد التقليدي واقتصاد المعرفة . ج- يبين العوامل والقوى الدافعة لاقتصاد المعرفة . - يعرف ماهية أبعاد اقتصاد المعرفة .

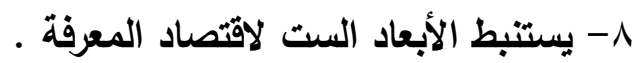

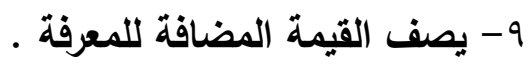
. 1 - يوضح المحددات السياقية لاقتصاد المعرفة . 11- بصنف في فئات المحددات السياقية لاقتصاد المعرفة . r ا- يشرح كل محدد من المحددات السياقية لاقتصاد المعرفة .

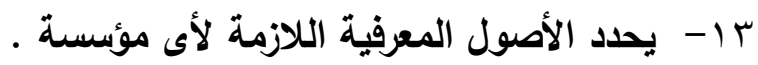
ع ا - يشرح كل مكون من مكونات المعرفة . 10

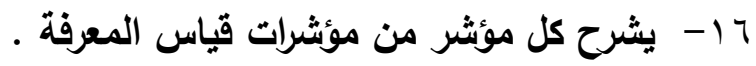
IV 1) - يكتشف المحاور الخاصة بمؤشرات قياس اقتصاد المعرفة . 9 ا - - يوضح ماهية مؤشرات اقتصاد المعرفة .

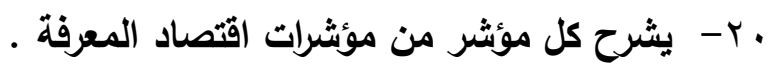

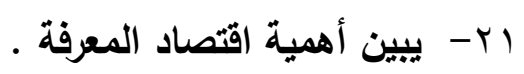




\section{r ب بتنتج مقومات اقتصاد المعرفة . \\ rr - يعدد متطلبات اقتصاد المعرفة .

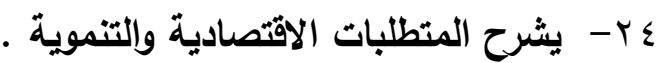 \\ هץ - يوضتح متطلبات التربية والبحث العلمى وإنتاج المعرفة . \\ ثنانباً: في الجانب المهارى:}

1 - يلاحظ بعناية الرسومات التوضيحية والكروكيات المرتبطة بموضوع الوحدة .

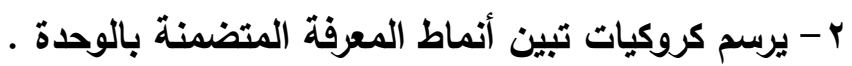

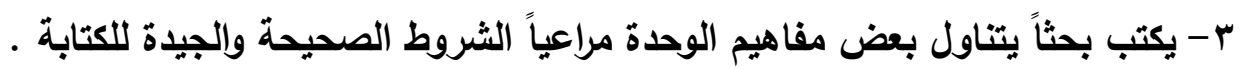

ثالثاً: في الجانب الوجدانىى:

- ب يهتم بالقراءة حول موضوع اقتصاد المعرفة .

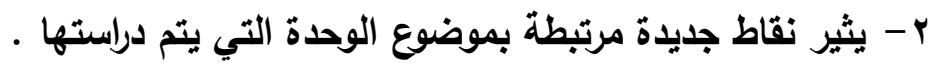

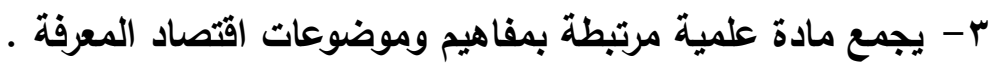

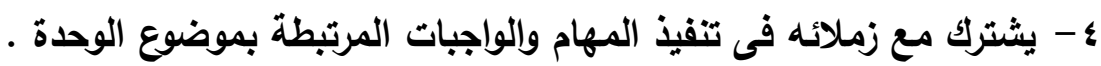

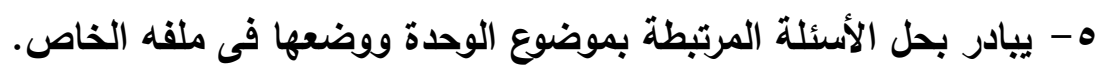

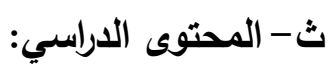

تضــن محتـوى الوحـدة العناصـر التاليـة: (مفهـوم اقتصـاد المعرفـة - أبعادهـا - القيمـة

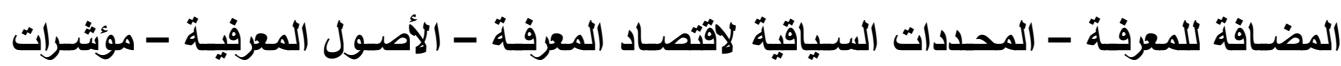

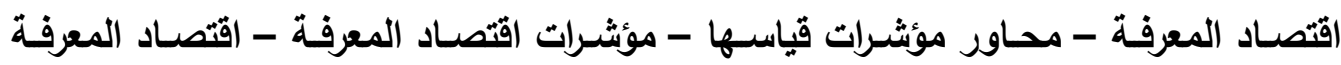
وأهميته - ركائز اقتصاد المعرفة - خصائص اقتصاد المعرفة ومقوماته - متطلبات اقتصاد (المعرفة).

ج- الأنشطة التعليمية:

استخدم الباحث مجموعـة مـن الأنشطة التعليميـة التى يـرى مناسبتها لتحقيـق أهداف

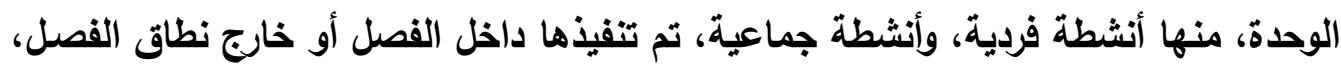
وقد تمثلت فى: الحوار والمناقشـة مـع الطلاب حول موضوعات الوحدة، الاهتمـام بجمـع مـادة

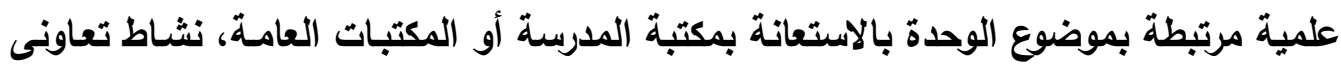
بين الطلاب لإنجاز الأعمـال المختلفـة التى تتطلبها جواتب التعليم في الوحدة، والمشـاركة 
الإيجابيـة فى الإجابـة عن الأسئلة التى تطرح على مجموعات العمل، والإجابـة عن الأسئلة

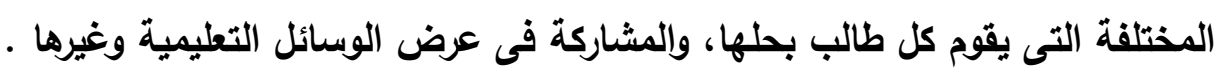
ح- مصادر التعلم:

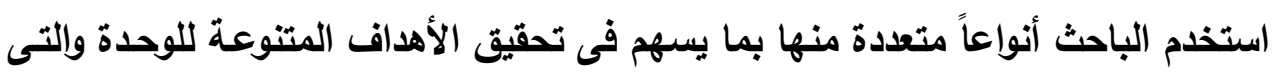

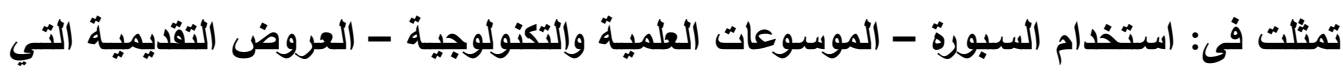

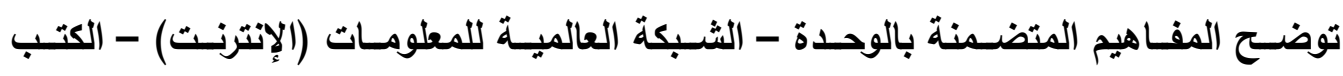
والأدبيات المرتبطة بموضوع الوحدة ـ إلى غير ذلك من الوسائل التى اتيح للباحث استخدامها

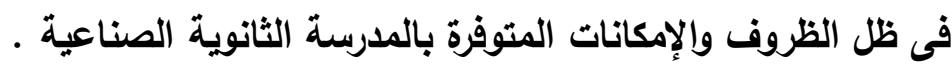
خ- طرق واستراتيجيات التدريس: اهتم الباحث باختيار استراتيجيات وأساليب تدريس متنوعة تناسب تحقيق أهداف الوحدة،

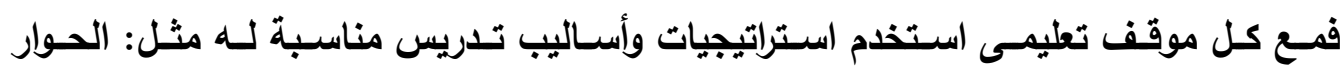
والمناقشة عند عرض وتقليم موضوع جديد، وحينما يتطلب الموقف أن يعمل كل طالب بصورة

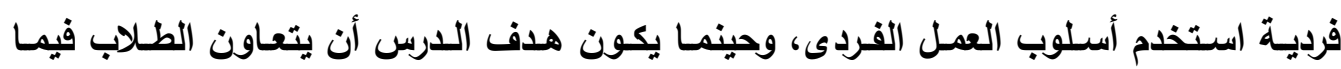

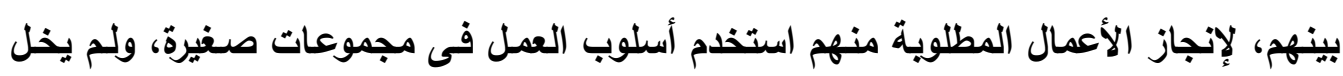
موقف من هذه المواقف من استخدام مهارات تدريس أخرى مثل: التهيئة المكانية واللفظية

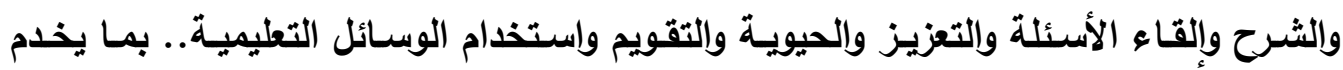
الموقف التعليمى، وإثارة دافعية الطالب للعمل والمشاركة والإنجاز، وتحقيق الأهداف المطلويـة

فى شتى جوانب النمو.

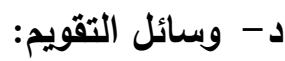

تم تقويم الوحدة فى ضوء الأهداف المحددة للتدريس، وفقاً للمراحل التالية: - التقويم القبلى Initiative Evaluation، وتم قبل عرض موضوع الوحدة بهدف تعرف مستوى الطلاب، وتحديد نقطة البداية الصحيحة للتعلم، وقد اتضـح ذلك من خـلال إجابتهم

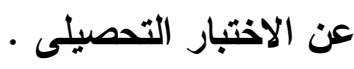
- التقويم التكـوينى Formative Evaluation، وتـم ذلـــ بعد شـرح كل مفهوم مـن

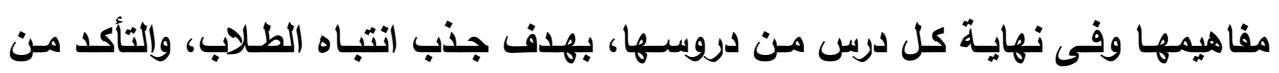
اكتساب الطلاب لها. 
- التقويم النهائى Summative Evaluation، وتم فى نهايـة دراسـة الطلاب للوحدة، حيث تم تقويم معلومات وقيم وإتجاهات الطلاب من خلال إجابتهم عن الاختبار البعدى .

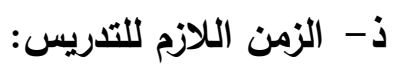
يقترح تدريس المفـاهيم المتضمنة بهذه الوحدة فى (أربعة أسـابيع)، بواقع (r حصة في الأسبوع)، والجدول التالى يبين تخطيط دروس الوحدة الثانية والزمن اللازم للتدريس:

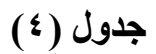

توزيع دروس الوحدة الثانية والزمن اللازم للتدريس

\begin{tabular}{|c|c|c|c|c|}
\hline الحصص عل اد & عنوان الارس & الارس & التاريخ & الأسبوع \\
\hline$r$ & 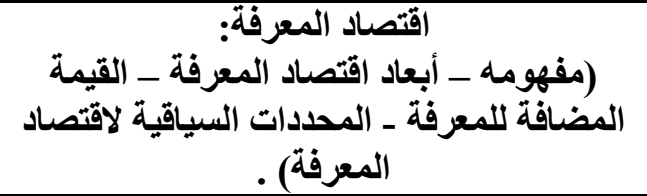 & الأول ال & & الأول ال \\
\hline$r$ & 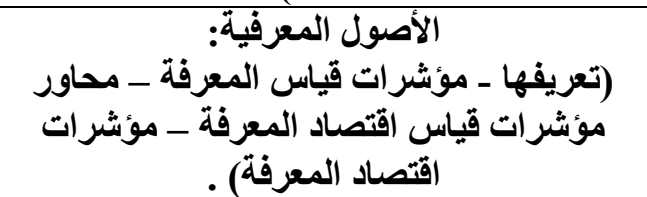 & الثانى & & الثانى الثى \\
\hline$r$ & 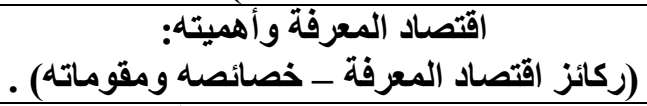 & 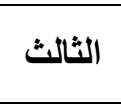 & & 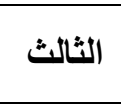 \\
\hline r & 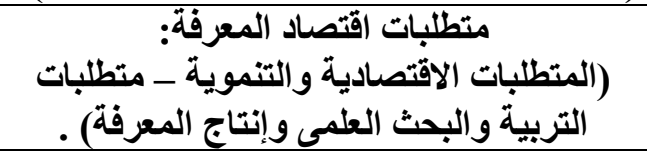 & 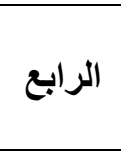 & & الرابع ل \\
\hline & إجمالي عدد الحصص = & \multicolumn{3}{|c|}{ إجمالي عدد الأسابيع = ؛ } \\
\hline
\end{tabular}

ويلاحظ من الجدول أن كل درس مـن دروس الوحدة يـتم تناولـه مـن خـلال جوانبهـ

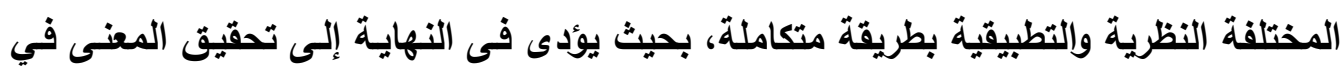

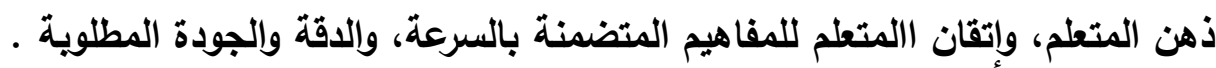

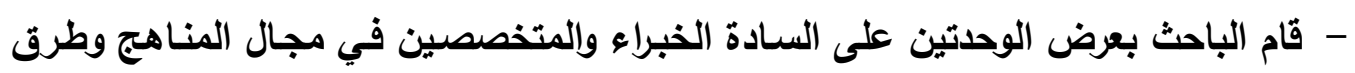

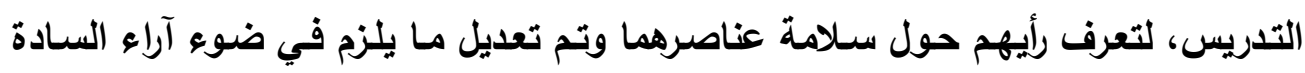

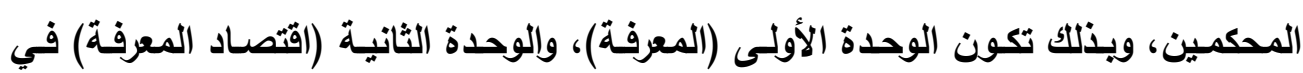

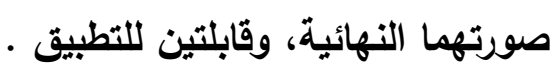




$$
\text { ه- أدوات البحث: تمثلت في: }
$$

بعد الانتهاء مـن إعداد الوحدتين قـام الباحث بإعداد أدوات تقويمهــا وقد تمثلت في الاختبار التحصيلى للوحدة الأولى (المعرفة)، والاختبـار التحصيلى للوحدة الثانية (اقتصـاد

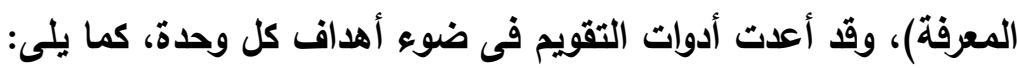

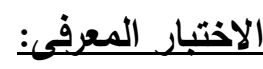
صمم الباحث اختباراً معرفياً لكل وحدة تدريسية، بهدف قياس مدى اكتساب الطلاب للمفاهيم

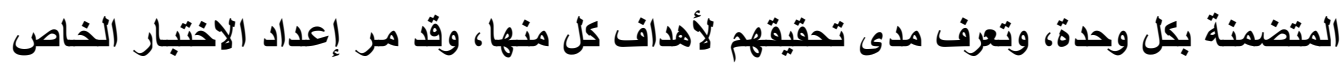

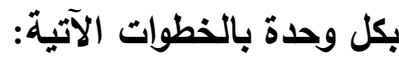
أ. وضع مفردات الاختبّار اعتمد الباحث فى صياغة مفردات الاختبار على الأسئلة الموضوعية، وقد اقتصر على

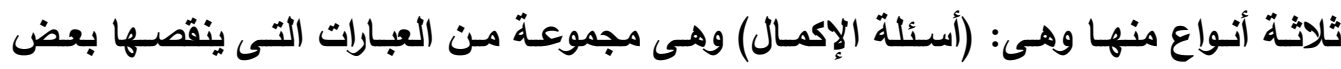

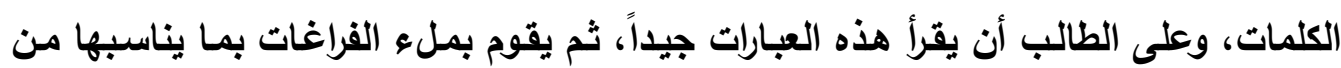

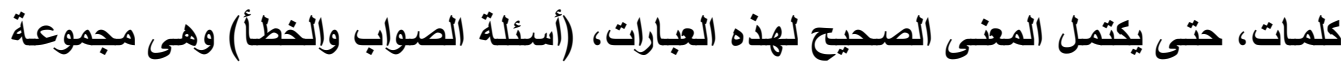
من العبارات بعضها صـواب، والبعض الآخر منها خطأ، وعلى الطالب أن يقرأ هذه العبارات

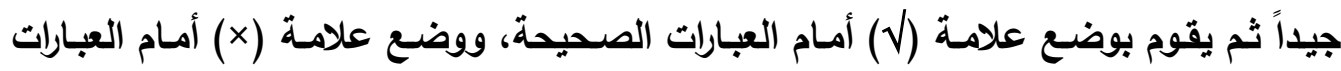
الخاطئة مع التعليل، (أسئلة الاختيار من متعدد) وهى مجموعة من الأسئلة أو العبارات، ولكل

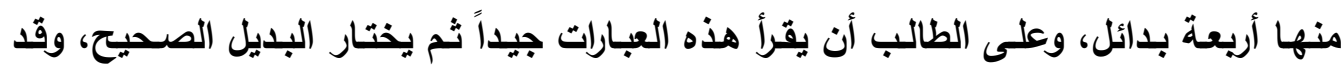

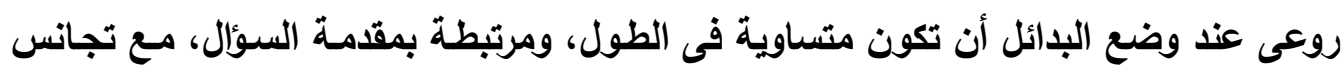
الاستجابات الخاطئة، كما روعى بساطة الصياغة، وعدم استخدام ألفاظ توحى بالإجابة . أما عدد الأسئلة والمفردات فقد تم تحديدها فى ضوء أوجـه التعلم فى الوحدة، بعد تحديد الأوزلن النسبية لكل منها، والتى يحدها جدول المواصفات التالى: 


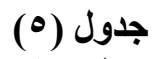

مواصفات اختبار الوحدة الأولى (المعرفة)

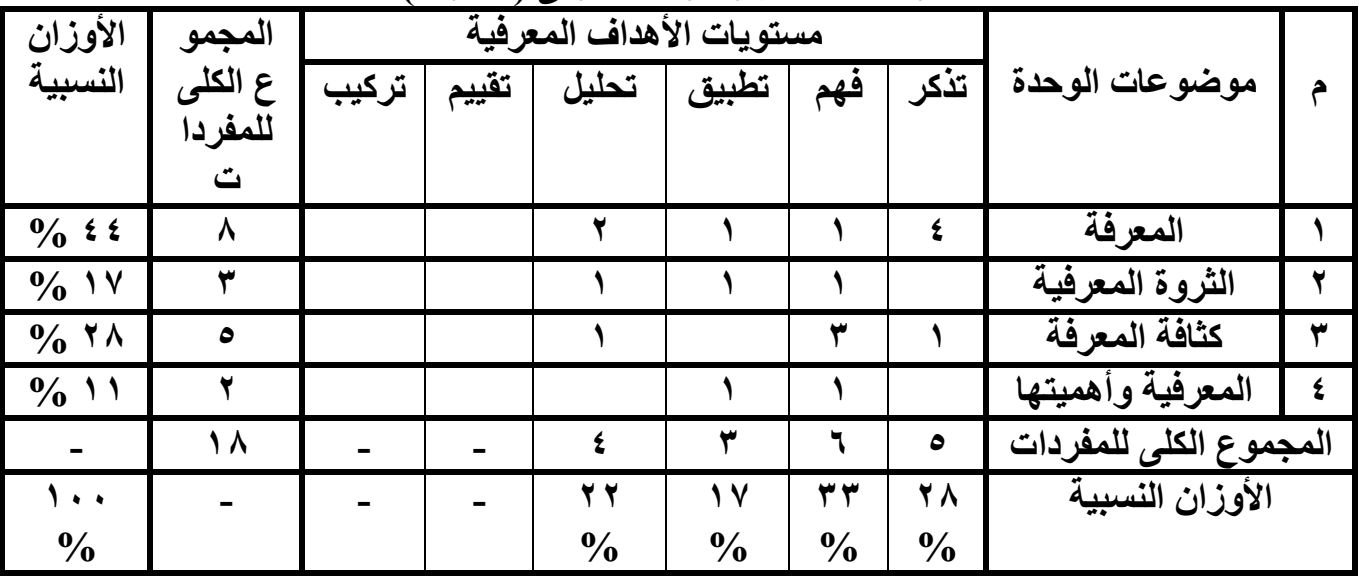

ويلاحظ من الجدول أن عدد المفردات المرتبطة بمستويات التذكر والفهم تزيد على

عدد المفردات المرتبطة بالمستويات الأخرى، وذلك يرجيع إلى طبيعة الموضوعات المرتبطة بالوحدة الأولى، وإلتى تحتاج إلى قاعدة أساسية من المعارف والمفاهيم التي تسـاعد الطلاب على اكتساب وفهم جوانبها المختلفة ـ أما فيما يتعلق بمواصفات اختبار الوحدة الثانية فيمكن توضيحه في الجول التالى:

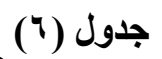

\begin{tabular}{|c|c|c|c|c|c|c|c|c|c|}
\hline \multirow{2}{*}{ الأوزان } & \multirow{2}{*}{ للمفردات الكلى } & \multicolumn{6}{|c|}{ مستويـات الأهداف المعرفية } & \multirow[b]{2}{*}{ موضوعات الوحدة } & \multirow[b]{2}{*}{ b } \\
\hline & & تركي & تقييم & تحليل & تطبيق & فهم & تذكر & & \\
\hline$\% \leq$ & 1. & & & $\varepsilon$ & & $\mu$ & $\mu$ & اقتصاد المعرفة & 1 \\
\hline$\% r r$ & $\Lambda$ & & & & 1 & $\varepsilon$ & $r$ & الأصول المعرفية & $r$ \\
\hline$\% 17$ & $\varepsilon$ & & & $r$ & & $\overline{1}$ & $\overline{1}$ & أهمية اقتصاد & $r$ \\
\hline$\%$ Ir & $\mu$ & & & & & $r$ & 1 & متطلبات اقتصاد & $\varepsilon$ \\
\hline- & ro & & & 7 & 1 & 1. & $\Lambda$ & للمجموع الكلّ & \\
\hline $\mathbf{0} \% 1 \cdots$ & - & - & - & $\%$ \% & $\%$ & $\varepsilon$ & $\begin{array}{l}\text { Mr } \\
\%\end{array}$ & وزان النسبية & \\
\hline
\end{tabular}

مواصفات اختبار الوحدة الثانية (اقتصاد المعرفة)

ويلاحظ من هذا الجدول أيضاً أن عدد المفردات المرتبطة بمستويات التذكر والفهم تزيد عن عدد المفردات فى المستويات الأخرى، ويؤكد ذلك أن فهم موضوعات الوحدة يحتاج 
إلى قاعدة أساسية من المعلومـات والمعارف والبناء عليها للوصول إلى مستويات عليا في الجانب المعرفى، ومن الملاحظ أيضاً زيادة القدرة على التحليل وتحديد العناصر المتضمنة بموضوعات ومفاهيم الوحدة، وهى قرات مطلوب اكتسابها وتتميتها لاى الطلاب. ب. تعليمات الاختبار : بومعات

بعد وضع مفردات الاختبار، أعد الباحث تعليمات الاختبار قبل تجريته ميداتياً، وذلك حتى

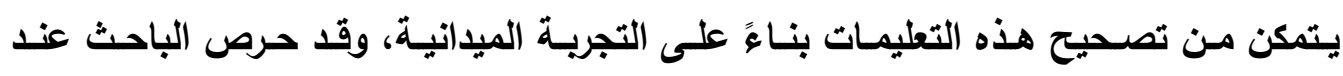
صياغة هذه التعليمات أن تكون واضحة ويسيطة، وتثثير إلى طريقة تسجيل الإجابة ومكانها،

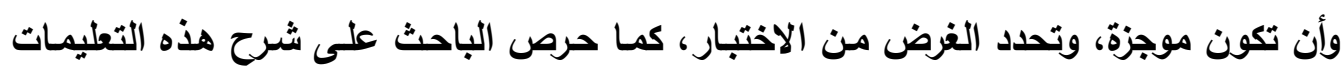

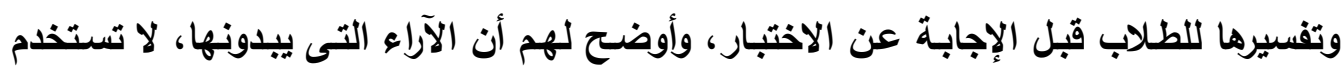
إلا لغرض البحث العلمى فقط . ج. تصحبح الاختبار: قسم الباحث درجـات كل سوأل تبعاً لعدد الإجابـات المتوقعة من الطالب، ويـذلك اختلفت درجات كل سؤال عن الآخر، ويالنسبة لاختبار الوحدة الأولى: كان عدد مفرداته (1 ا مفردة)

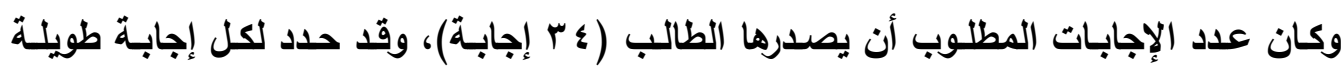
منها (درجتان)، ولكل إجابة قصيرة (درجة واحدة) هذا بالنسبة لأسئلة التكملة، بينما أسئلة الاختيـار من متعدد وأسئلة الصواب والخطأ، فقد حدد لكل إجابـة (درجتان) يحصل واجدل عليهما الطالب فى حالة إجابته عن السؤال إجابـة صحيحة، ويذلك يصبح المجموع النهائى لارجات

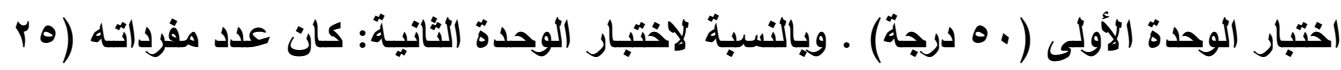

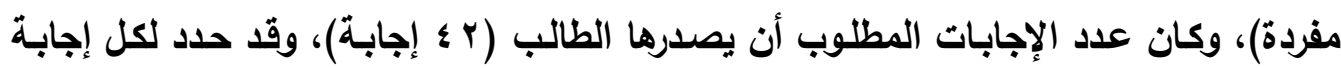
طويلة منها (درجتان)، ولكل إجابة قصيرة (درجة واحدة) هذا بالنسبة لأسئلة التكملة، بينما أسئلة الاختيار مـن متعدد وأسئلة الصـواب والخطأ، فقد حدد لكل إجابـة (درجتان)، يحصل وابله

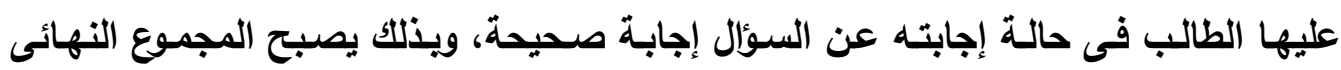

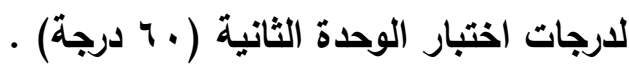
ذ. نمن الاختبار: تم إجراء التجريـة الإستطلاعية للاختبـارين التحصيليين وذلك لتعرف الزمن الـلازم لكل منهمـا، على مجموعة من طلاب الصف الثالث تخصص الزخرفة والإعلان بمدرسـة القاهرة 
الفنية للصناعات النسيجية بــن عددها ( • ط طالب)، وتم حسـاب الزمن مـن خـلال المعادلة

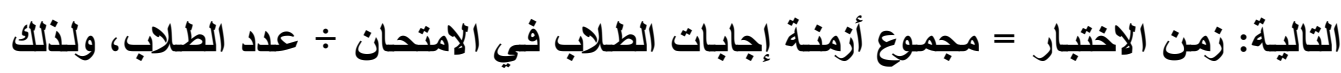

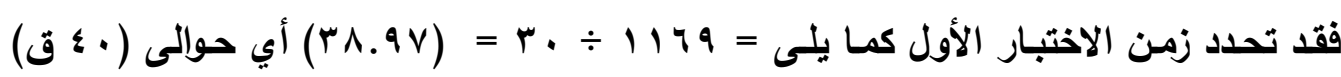

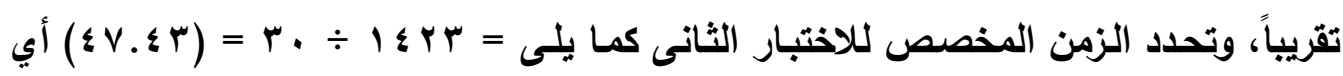

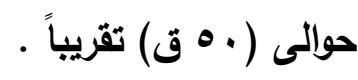
هـ. صدق الاختبار:

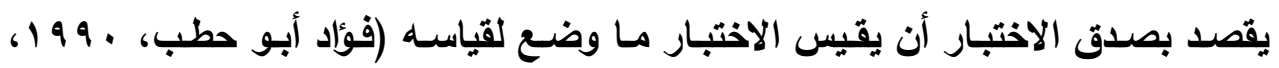

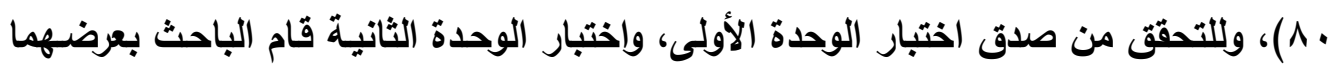

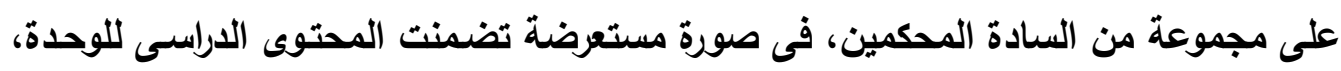

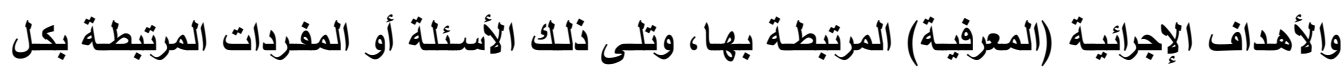
منهما، وطلب الباحث من السادة المحكمين:

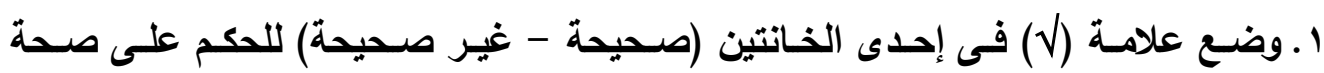
صياغة الأسئلة. r. وضع علامة (ل) فى إحدى الخانات (مناسبة - إلى حد ما - غير مناسبة) وذلك للحكم

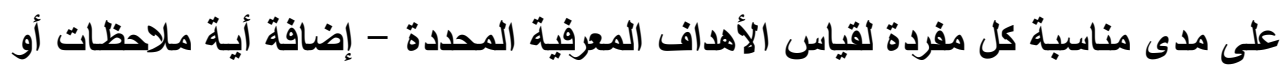
آراء يرون إضافتها. وفى النهاية حسب الباحث النسب المئويـة لتكرار موافقة المحكمين عن كل سؤال من أسئلة الاختبارين، وقد تراوحت بين (ه \% \% ، . . 1\%)، وكاتت هناك بعض الآراء والملاحظات حول صياغة بعض الأسئلة، وتم تعديلها فى ضوء آراء السادة المحكمين . و. ثبات الاختبار:

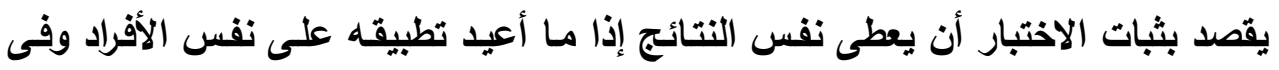
نفس الظروف ـ لذا فقد حسب الباحث ثبات الاختبارين التحصيليين (للوحدة الأولى، والوحدة الثانيـة) عن طريق إعـادة التطبيق Pre-test حيث طبق الاختبـارين المعرفيين للوحدتين الأولى والثانية على عينة من طلاب الصف الثالث الثانوى الصناعى من مدرسة القاهرة الفنية

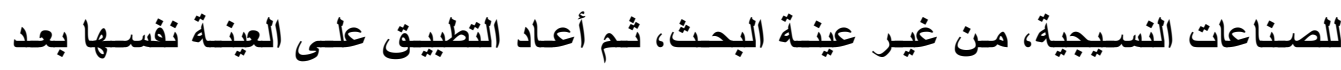
أسبوعين، وحسب معامل الارتباط بين التطبيقين، مستخدماً المعادلة الآتية: 


$$
\text { ن مج س ص - مج س مج ص }
$$

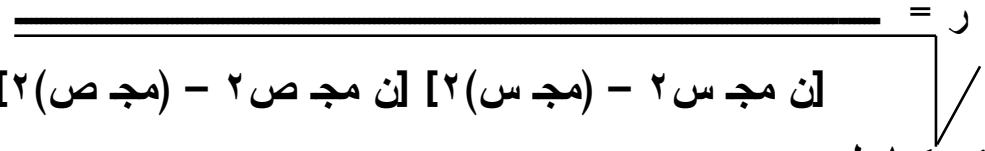

$$
\begin{aligned}
& \text { فكانت النتائج كما يلى: }
\end{aligned}
$$

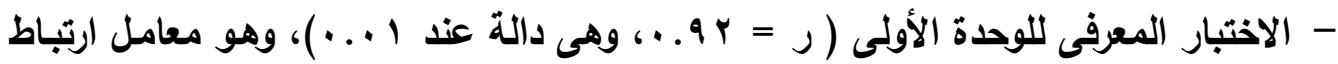
موجب دال، يدل على ثبات الاختبار.

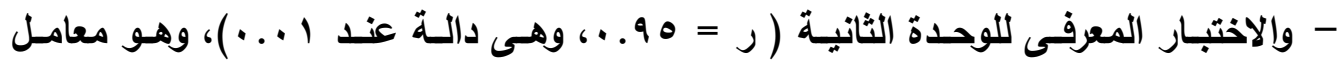
ارتباط موجب دال، يدل على ثبات الاختبار. ويذلك أصبح الاختباران صالحين للتطبيق، بعد

التأكد من صدقهما وثباتهما

$$
\text { ج - تجربة البحث: }
$$

أ- اختيار عينة البحث: تم اختيار عينة البحث من طالبات الصف الثالث من تخصص الزخرفة والإعـلان بمدرسـة (ه 10 مـايو الثانويـة الصناعية بنـات) وهـى إحـدى المدارس التابعة لإدارة المستقبل التعليمية بمحافظة القاهرة، نظراً لقريها من مكان عمل وإقامـة الباحث، ونظراً لمساعدة إدارة المدرسة وتسهيلها لعملية تتفيذ إجراعات تجربة البحث . ب- تطبيق أدوات البحث قبلياً على الطلاب عينة البحث . تـم تطبيق أدوات البحـث (الاختبـار التحصيلى للوحدة الأولى)، (الاختبـار التحصسيلى للوحدة الثانية) فبلياً، قبل القيام بتدريس وحدتى المقرر المقترح للصف الثالث، وذلك

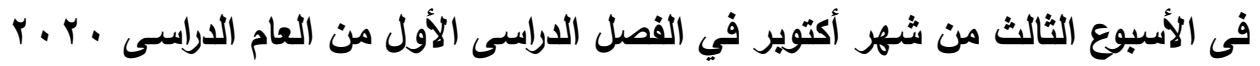
/ ا Y . Y ، وعند بداية التطبيق تم تعريف الطالبات بأدوات البحث والغرض منها، كما تم التأكد من وضوح التعليمات وتم الرد على استفسارات الطالبات الخاصة بكل اختبار. ت- تدريس وحدتى (المعرفة)، (اقتصاد المعرفة) للطلاب عينة البحث . تم تدريس وحدتى (المعرفة)، (اقتصـاد المعرفة)، وهما من الوحداث المتضمنة بالمقرر المقترح لطلاب الصف الثالث من تخصص الزخرفة والإعلان بالمدرسة الثانويـة الصناعية لعينـة عددها ( ب طالبـة) مسن طالبات (مدرسـة ه 1 مـايو الثانويـة الصـناعية بنـات التابعـة لإدارة المسـتبل التعليميـة بمحافظة القـاهرة)، باسـتخدام اسـتراتيجيات التـريس المناسـبة لكل موقف تعليمسى، ومـن خـلال الأنشـة التعليميـة سـواء داخل الفصسل أو 
خارجه، ومن خلال مصادر التعلم المتعددة، وقد استغرق التدريس (ثمانية أسـابيع)، وهو الزمن المخصص والمقترح لتدريس الوحدتين، بواقع (حصتان أسبوعياً)، كما قام الباحث

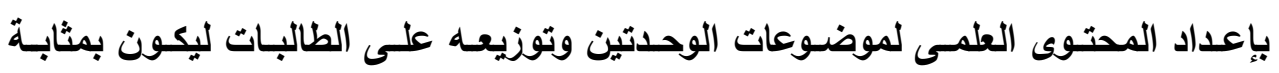

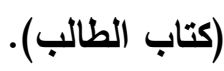

ث- تطبيق أدوات البحث بعدياً على الطلاب عينة البحث: تم تطبيق أدوات البحث بعدياً على نفس العينة (طالبات الصف الثالث) بعد الانتهاء من البن تدريس وحدتى (المعرفة)، (اقتصاد المعرفة) من وحدات المقرر المقترح للصف الثانيات الثالث

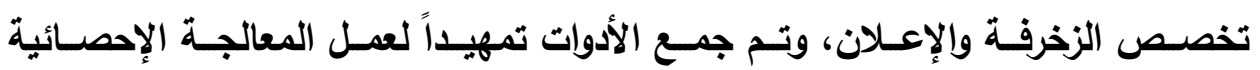

$$
\text { V- المنائج البحثة . }
$$

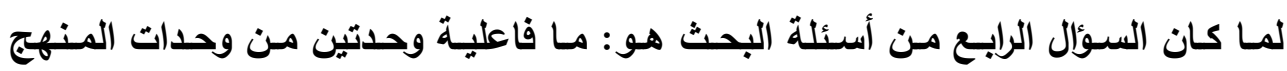
المطور في تنميـة مفاهيم اقتصـاد المعرفة لـى طلاب تخصص الزخرفة والإعلان بالمدرسـة

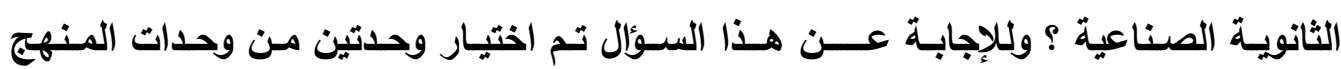

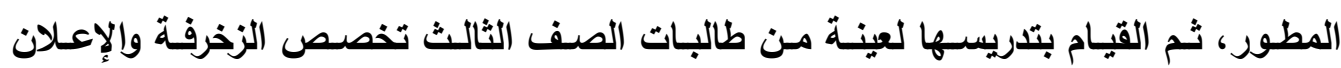

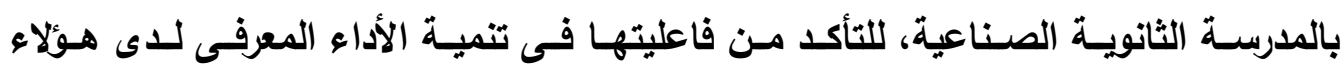
الطالبات، وتحقيق الأهداف المحددة لهذه الوحدات، والوصول بالأداء إلى الارجة المطلويـة،

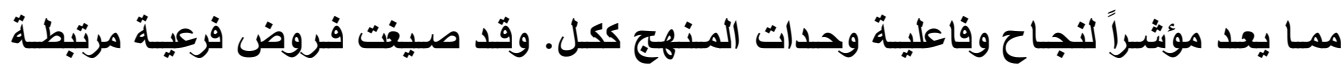
بالجانب المعرفى لكل وحدة من الوحدات، وسوف نتناول التحقق منها فيما يلى: أ- الفرض الخاص بالجاتب المعرفي للوحدة الأولى (المعرفة): ينص الفرض الأول الخـاص بالجانب المعرفى للوحدة الأولى على أنسه (يوجد فرق دال

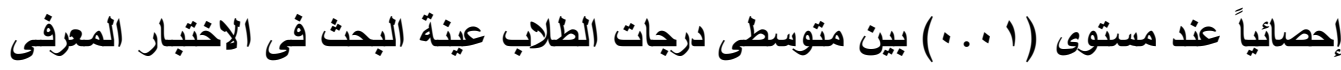

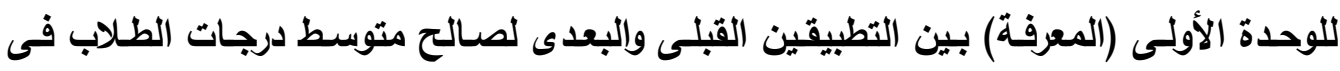

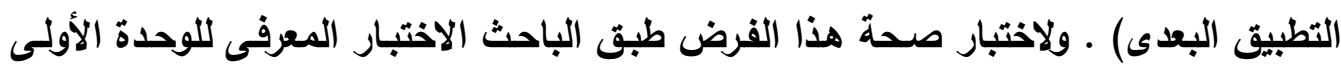
قبل التدريس ويعده، ثم حسب الفروق بين التطبيقين القبلى والبعدى، وذلك باستخدام اختبار "ت" فكانت النتائج كما يلى 
(V) جدول

قيم "ت" لنتاتج التطبيق القبلى والبعدى للاختبار المعرفى للوحدة الأولى

\begin{tabular}{|c|c|c|c|c|c|c|c|}
\hline الالالةي & قيمة & معامل & ن & الالحعراف & المتوسط & التطبيق & الوحدة \\
\hline \multirow{2}{*}{$\because \cdot 1$} & \multirow{2}{*}{$\Gamma \leqslant . \wedge}$. & \multirow{2}{*}{$\therefore$ VYO } & \multirow{2}{*}{$r}$. & $r .01$ & 10.9. & قبلى & \multirow{2}{*}{ الأولى } \\
\hline & & & & $r . r v$ & rr.IT & بعدى & \\
\hline
\end{tabular}

يتضح من الجدول السابق أن قيم "ت" دالة عند مستوى ( ( ...)، وهذا يعنى وجود فرق فى

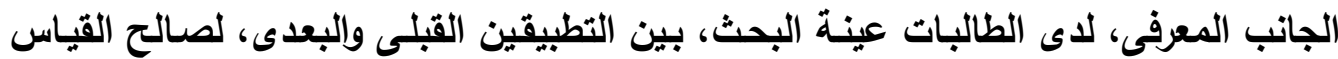

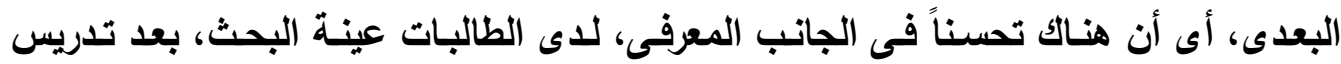

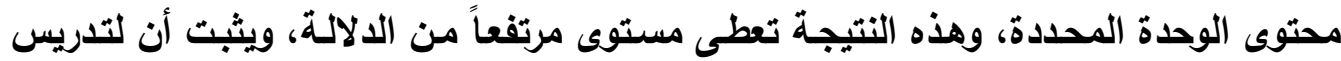

الوحدة أثراً كبيراً فى تحصيل الطالبات للجوانب المعرفية المتضمنة بها. ب- الفرض الخاص بالجانب المعرفي للوحدة الثانية (اقصاد المعرفة): ينص الفرض الثـانى الخـاص بالجاتب المعرفى للوحدة الثانيـة على أنـه (يوجد فرق دال إحصائياً عند مستوى ( ( ...) بين متوسطى درجات الطلاب عينة البحث فى الاختبار المعرفى للوحدة الثانية (اقتصاد المعرفة) بين التطبيقين القبلى والبعدى لصالح متوسط درجات الطلاب فى التطبيق البعدى) ـ ولاختبار صحة هذا الفرض طبق الباحث الاختبار المعرفى للوحدة الثانية قبل التريس ويعده، ثم حسب الفروق بين التطبيقين القبلى والبعدى، وذلك باستخدام

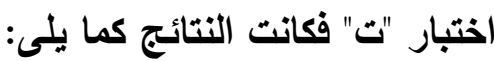

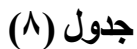

قيم "ت" لنتائج التطبيق القبلى والبعدى للاختبار المعرفى للوحدة الثانية

\begin{tabular}{|c|c|c|c|c|c|c|c|}
\hline مستوى الالاة & قتيمة & الارتباطل & ن & الالحعراف & المتوسط & التطبيق & الوحدة \\
\hline \multirow{2}{*}{$\because 1$} & \multirow{2}{*}{$0 \leqslant .9$} & \multirow{2}{*}{$\therefore \wedge v$. } & \multirow{2}{*}{$\mu}$. & $9 . \mu 1$ & $1 \leq . \mathrm{TV}$ & قبلى & \multirow{2}{*}{ الثانية } \\
\hline & & & & $1 V . Y q$ & $\leqslant 9.0$. & بطدى & \\
\hline
\end{tabular}

يتضح من الجدول السابق أن قيم "ت" دالة عند مستوى (1 (. . )، وهذا يعنى وجود فرق فى الجانب المعرفى، لاى الطالبات عينة البحث، بين التطبيقين القبلى والبعدى، لصالح

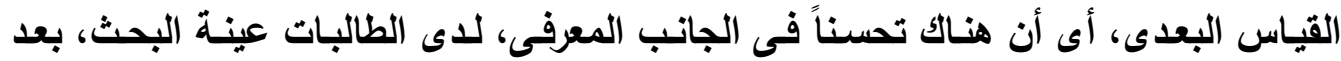
تلديس محتوى الوحدة المحدةة، وهذه النتيجة تعطى مستوى مرتفعاً من الدلالة، ويثبت أن لتدريس الوحدة أثراً كبيراً فى تحصيل الطلاب للجوانب المعرفية المتضمنة بها. 


\section{وذلك يرجع إلى ما يلى: - مانى}

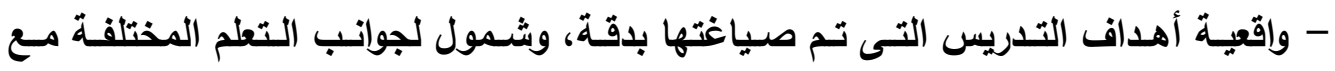
مراعاتها لمعاييز وشروط الأهداف التدريسية الجيدة . - أن الوحدات التي تم إعدادها وتخطيطها قد تتاولت الجانب المعرفى تناولاً جديداً، حيث تم تناول مفاهيم اقتصاد المعرفة بطريقة سهلة ومبسطة ومتدرجة، ويصورة مترابطة ومتكاملة تحقق المعنى فى ذهن الطالبات ويذلك تتحقق وحدة المعرفة، مما جعل الحقائق والمفـاهيم

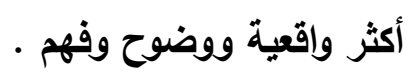

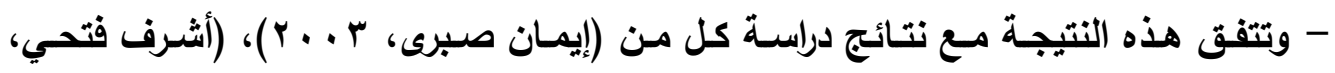

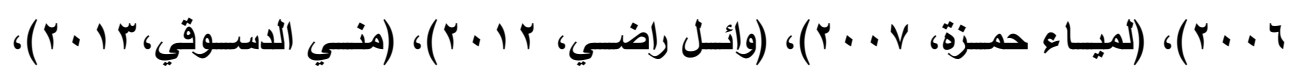

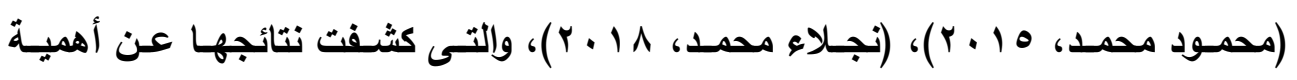
صياغة وتتاول موضوعات المحتوى التعليمى بشكل تكاملى وظيفى ومبسط، بما يسـاعد على اكتساب الطلاب للمفاهيم المرتبطة بتدريس مواد تخصصه واتقانه لها ـ مونس

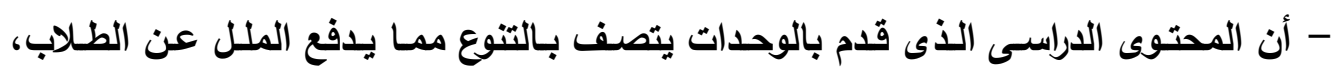

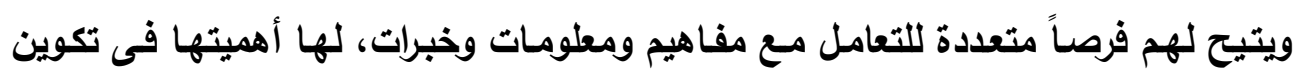
قدراتهم المهنية . - استخدام الباحث أنثطة تعليمية متنوعة ومتعددة ومناسبة لمستوى الطلاب سواء داخل

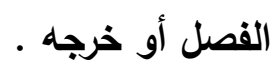
- استخدام استراتيجيات تدريس متنوعة، مناسبة لتنوع موضوعات الوحدات التعليمية، وكان

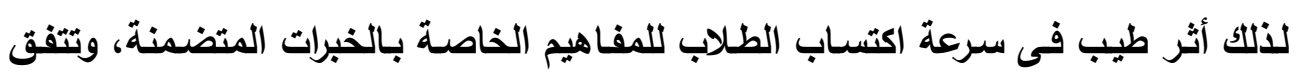

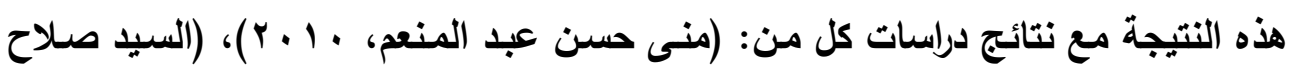

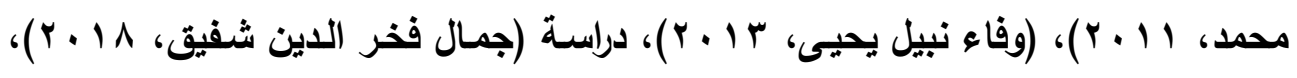

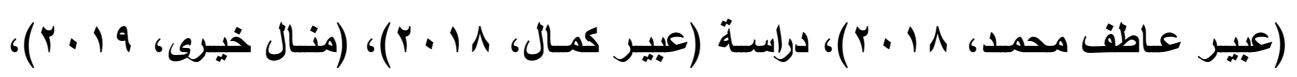

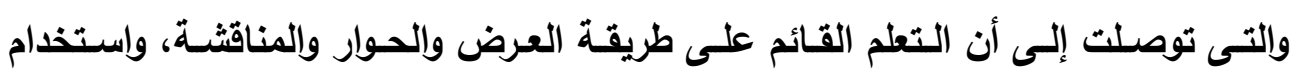

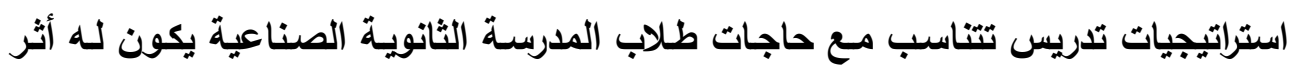

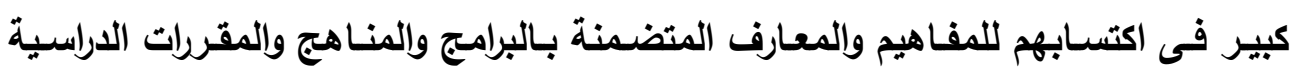
المختلفة . 
- اسـتخدام الباحث لمصـادر تعلـم ووسـائل تعليميـة متعددة سـاعدت فـى اكتســاب الطـلاب للمفـاهيم المتضــنة بالوحـدات، تمثلت فئ العروض التقليميـة - الموسـوعات العلميـة والتكنولوجية - الثبكة العالمية للمعلومـات (الإنترنت)، الكتب والأدبيات المرتبطة، والتي ساهمت في تحقيق فهم واعى للطلاب وجعلت الموقف التعليمى أكثر حيويـة وتفاعل وإثارة

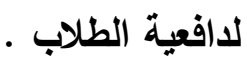

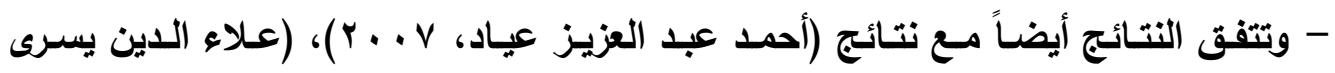

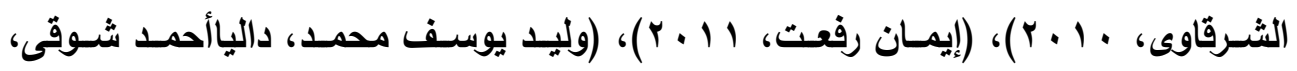

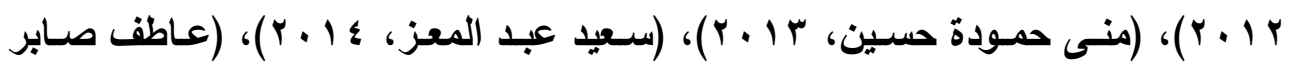

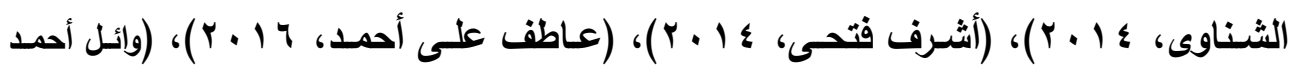

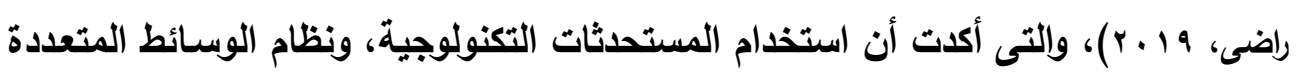

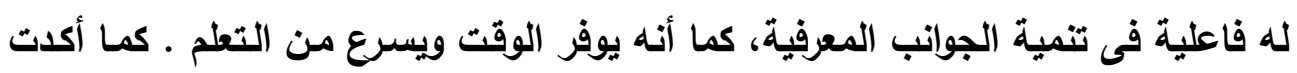
أن استحداث وسـائل تدريسية متطورة يسهم فى رفع قدرات الطلاب المهاريـة والابتكارية،

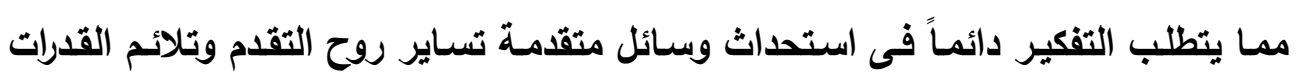

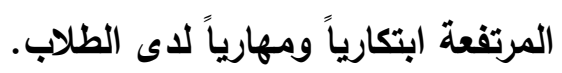
- استخدام وسائل تقويم متنوعة وشاملة ومرتبطة بجواتب النمو المختلفة، وتتميز الاختبارات

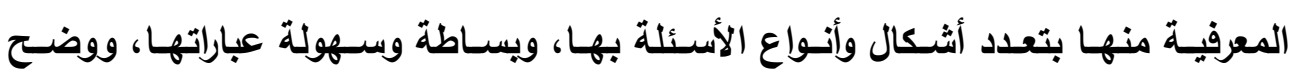

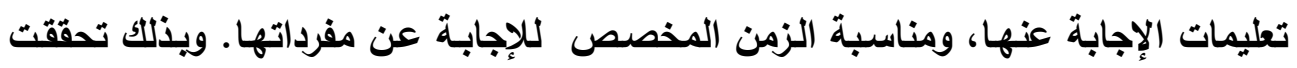

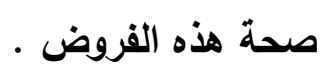
- ولمعرفة مدى فاعلية المنهج المطور فى تنمية الأداء المعرفى لدى الطلاب، قام الباحث بحسـاب حجم التأثير(Effect size) ويدل حجم التأثير على مدى تأثير الانتماء لعينة

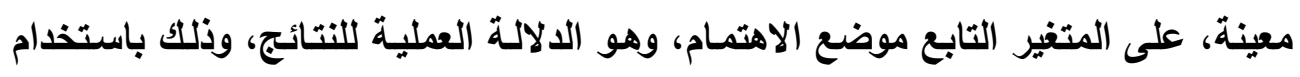

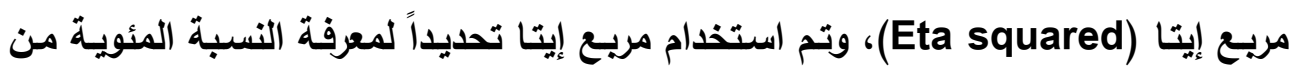
تباين المتغير التابع الأى يمكن تفسيره بمعرفة المتغير المستقل، ويشير حجم التأثير هنا

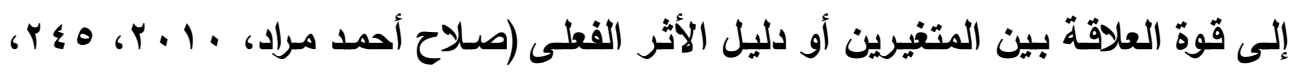

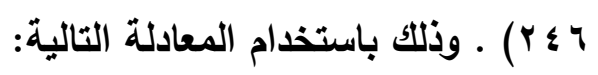


$r$

فكاتت مربع إيتا

$$
\begin{aligned}
& \text { التتائج كما يلي : }
\end{aligned}
$$

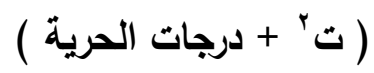

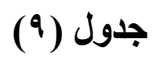

قيمة مربع إيتا للاختبارين المعرفيين

\begin{tabular}{|c|c|c|c|}
\hline قيمة مربع إيتا & درجات الحرية & قيمة (ت) & الوحدة \\
\hline $.9 V V$ & $r \Lambda$ & $r \varepsilon . \wedge$. & الأولى \\
\hline .999 & $r \Lambda$ & $0 \leqslant .9$ & الثانية \\
\hline
\end{tabular}

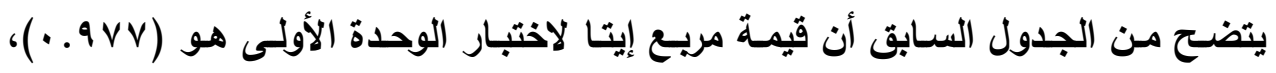

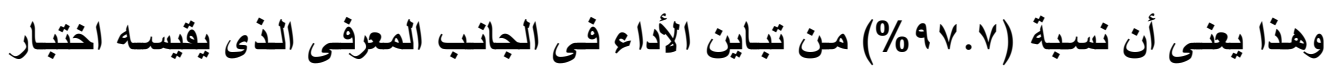
الوحدة الأولى (المتغير التابع) يمكن أن يفسر عن طريق المنهج المطور الذئى طبقه الباحث

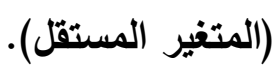

ويتضـح مـن الجـدول السـابق أيضـاً أن قيمـة مريــع إيتـا لاختبـار الوحـدة الثاتيـة هـو

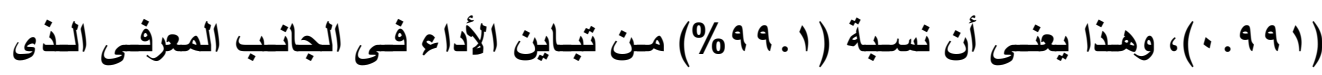

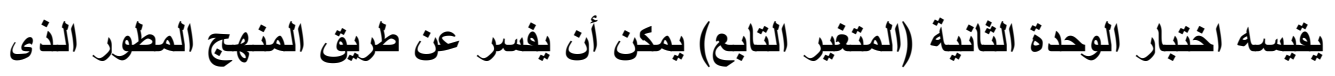
طبقه الباحث (المتغير المستقل). A

في ضوء ما أسفرت عنه نتائج البحث يمكن تقديم التوصيات التالية:

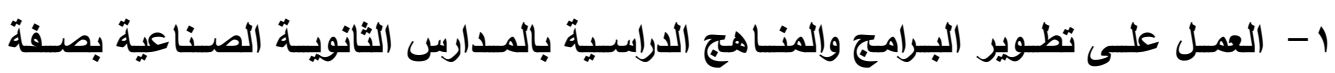
مستمرة. r - ضـروة الاهتمـام بتــريس مفــاهيم اقتصـاد المعرفـة لجميـع الطـلاب في التخصصـات

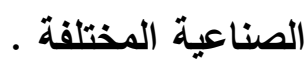

r- الاهتمام بتدريس مفاهيم ريادة الأعمال واقتصاد المعرفة لطلاب المرحلة الجامعية . ـ - تدريب الطلاب على كيفية عمل دراسات الجدوى للمشروعات الصغيرة في جميع المراحل التعليمية . التبة 
ه- اعتبار المشروعات الصناعية الصغيرة منطلقاً لتحقيق التنمية الاقتصادية والاجتماعية

$$
\text { في مصر . في }
$$

צ- تدريب الطلاب على كيفية التواصل مع الجهات الحكومية وغيرها ممن يقدمون الدعم

والمساندة لأفكارهم البنائة ولمشروعاتهم الإنتاجية المتميزة والثرائدة .

- Vوفير التمويل اللازم للرؤى والأفكار والمبتكرات التي يقدمها الطلاب والخريجين . ^- تبنى أصحاب الإبداعات والمخترعات وتوفير جميع السبل لتحقيق أهدافهم وغاياتهم النبيلة النحا

9- تـوفير الـدعم المـادى والمعنـوى للبـاحثين في المراكز البحثيـة والجامعـات الحكوميـة والخاصة . توفيز لـ

• 1 - التشـيع المستمر لكل مـا مـن شـأنه أن يسـاهم في تحقيق رفعـة وتقدم ونهوض

$$
\text { 9 - مقتزحات البحث: مصرنا العبيبة . }
$$

يقترح الباحث إجراء المزيد من الدراسات والبحوث المنبثقة من البحث الحالي، ومنها:

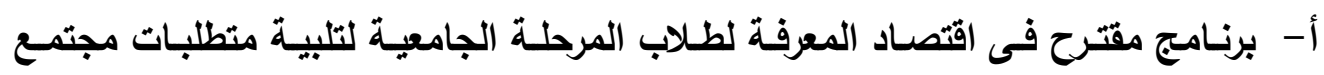
المعرفة . برنجة مفترة

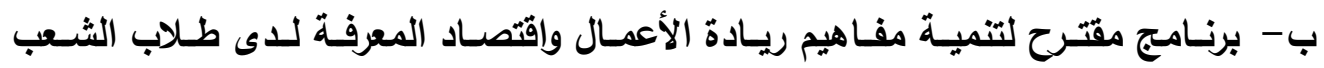

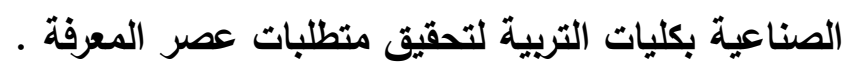
ت- برنامج مقترح فى المشروعات الصناعية الصغيرة لطلاب التعليم الثانوى الصناعى وأثره على تنمية الاتجاهات الإيجابية نحو تحقيق نهضة المجتمع المصرى .

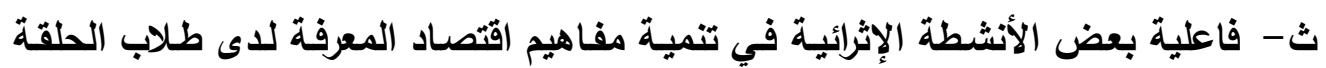
الثانية من التعليم الأساسى . 


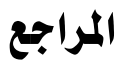

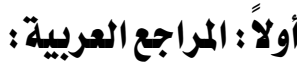

1- أحمد حسين اللقانى: نطوير مناهج التعليم، (القاهرة: عالم الكتب، 1990 (1).

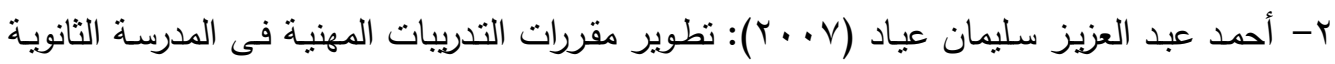
الصناعية الزخرفية فى ضوء المستحدثات التكنولوجية، (رسالة دكتوراه، غير منشورة، كلية التربية جامعة حلوان)

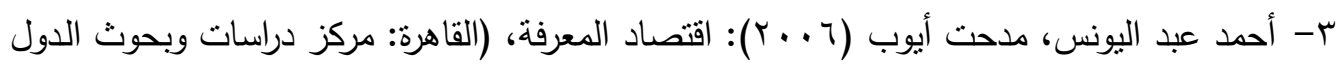
- النامبة)

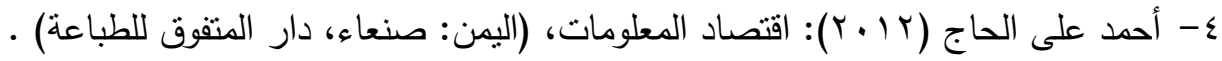

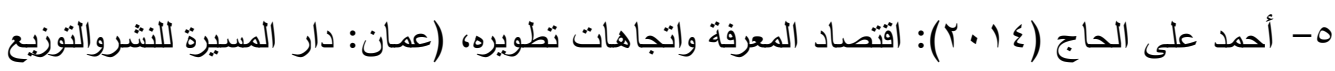
والطباعة).

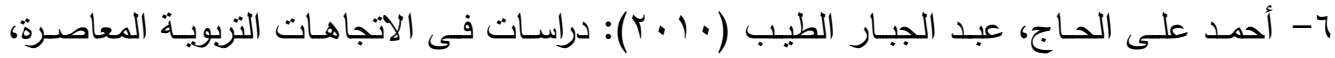

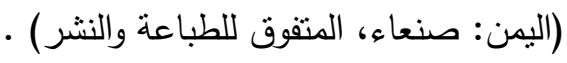

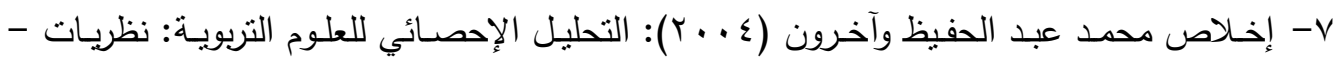
تدريبات - تطبيقات، (القاهرة: مكتبة الأنجلو المصرية) .

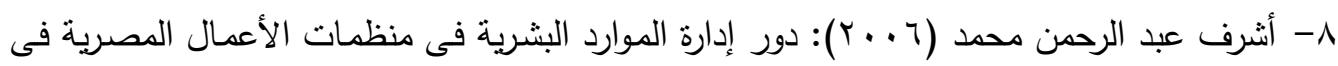
ظل اقتصاد المعرفة، (رسالة دكتوراة، غير منشورة، كلية التجارة - جامعة القاهرة) .

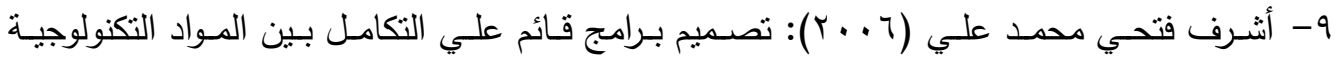
والتدريبات المهنية لتتمية المهارات العملية لدي طلاب المدرسة الثانوية الصناعية وقياس فاعليته، (رسالة دكتوراه، غير منشورة، كلية تربية - جامعة حلوان) .

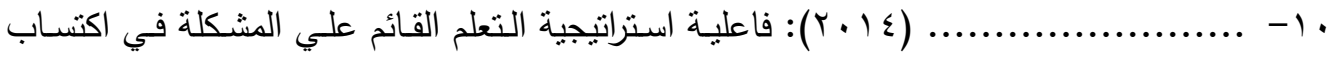
طـلاب تخصص الزخرفـة والإعـلان بالمدرسـة الثانويـة الصـاعية مفـاهيم مـادة المقايسـات وتتميـة

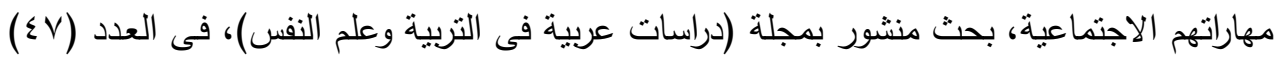

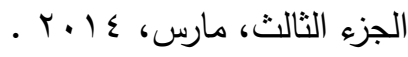

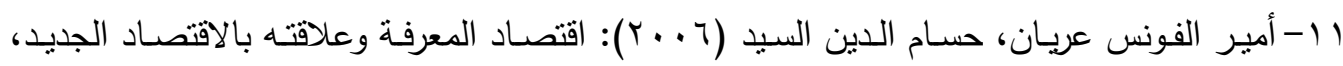
(مركز دراسات وبحوث الدول النامية، كلية الاقتصاد والعلوم السياسية، جامعة القاهرة) . 
rا- إيمان محمد رفعت (11 ـ r): فاعلية استراتيجية التعلم القائم علي المشكلة في اكتساب أطفال

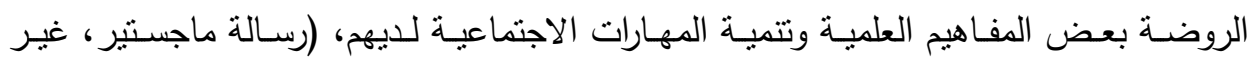

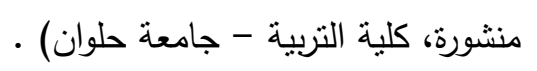

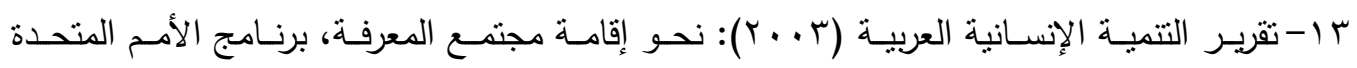
• الإنمائي

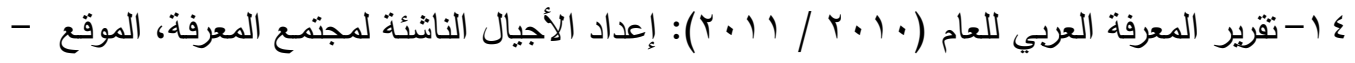
(http://www.mbrfoundation.ae/Arabic)

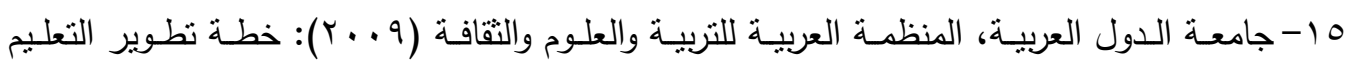
بالوطن العربي، (تونس، مطبعة المنظمة العربية للتربية والعلوم والثقافة) .

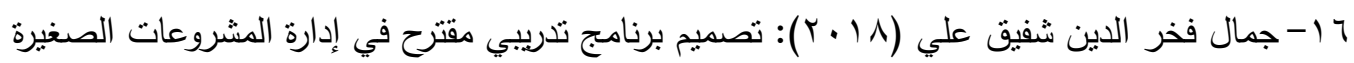

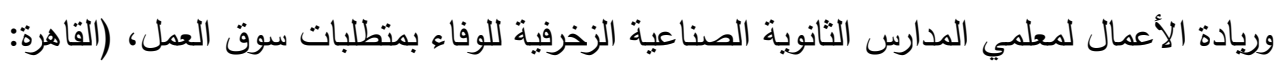

$$
\text { المركز القومي للبحوث التربوية). }
$$

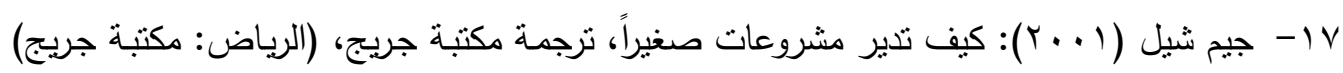

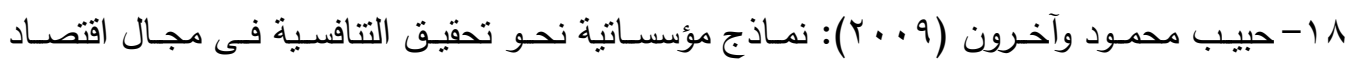

$$
\text { المعرفة، (عمان: مركز الدراسات). }
$$

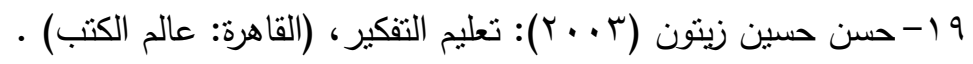

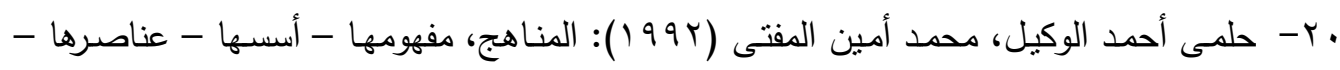

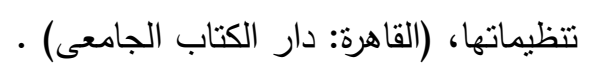

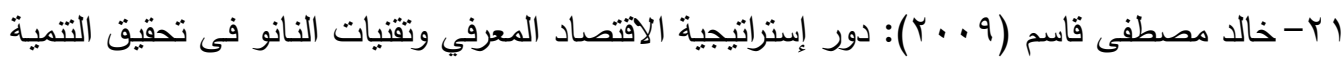

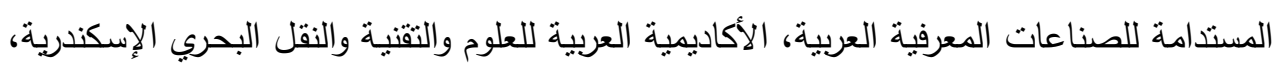

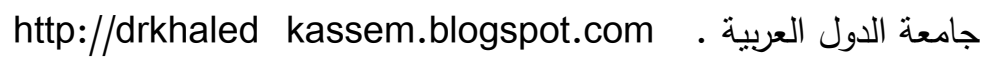

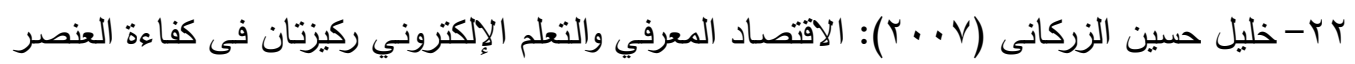

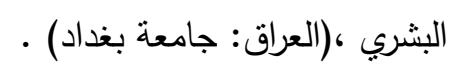
rץ- رشدى لبيب، فايز مراد مينا (ب999 (19): المنهج منظومة لمحتوى التعليم، (القاهرة: مكتبة الأنجلو

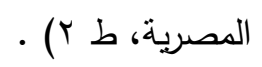

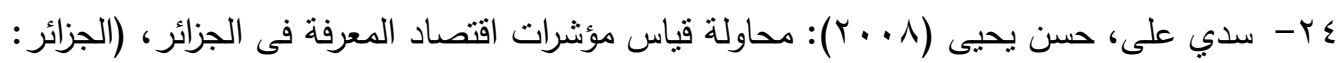
جامعة ابن خلدون). 


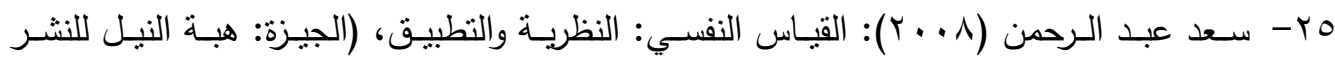
والتوزيع).

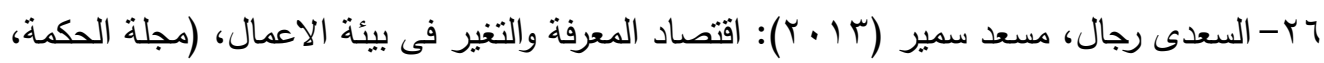

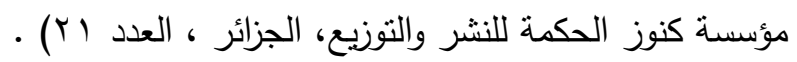

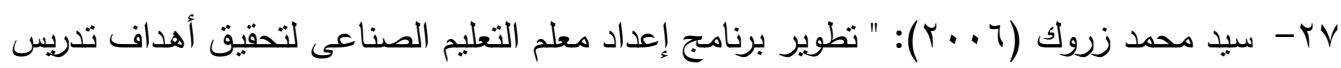

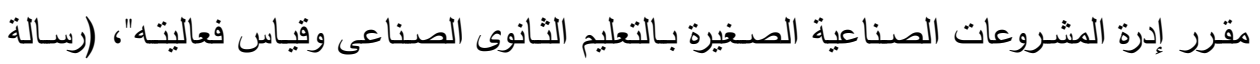

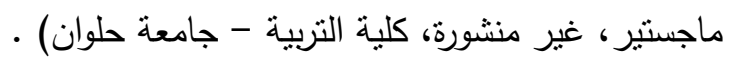

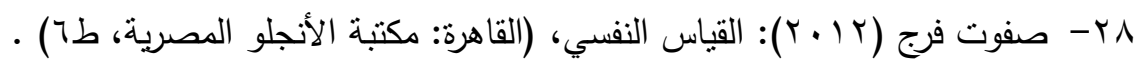

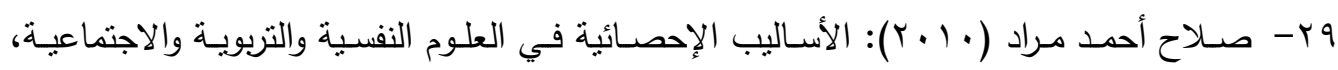

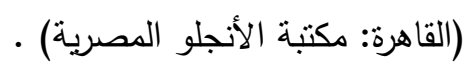

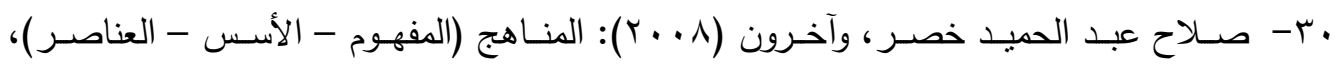

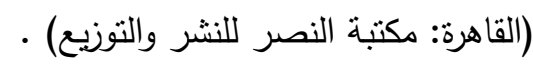
اب- عاطف صابر الثناوي (ع ( ب)): تطوير برنامج الإعداد التخصصي لفني نجارة الأثاث بالمدرسة

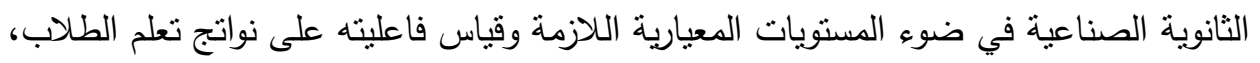

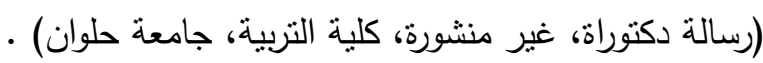

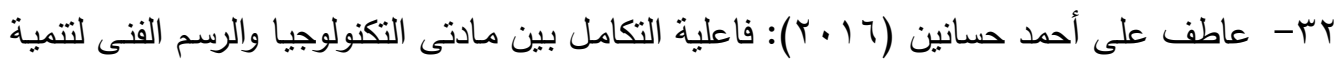
مهارات التفكير والمهارات اليدوية المرتبطة بالصناعات الإبداعية لدى طلاب المدارس الثانوية الصناعية " ، (رسالة دكتوراه، غير منشورة، كلية التربية - جامعة حلوان) .

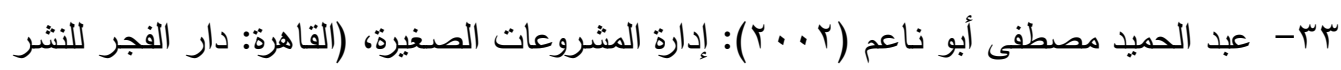
• والتوزيع)

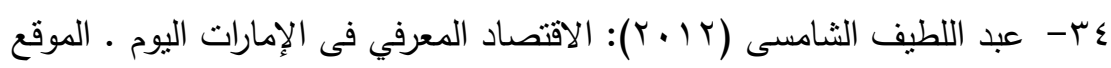
http://www.emaratalyoum.com.

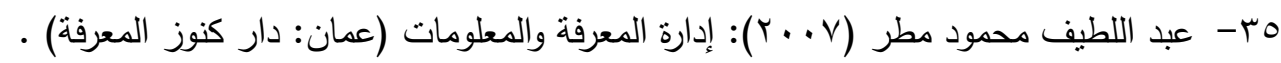

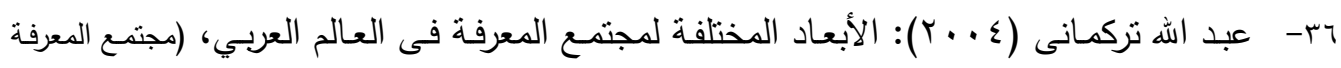
وأبعاده فى العالم العربي، تونس). V • والتوزيع) 


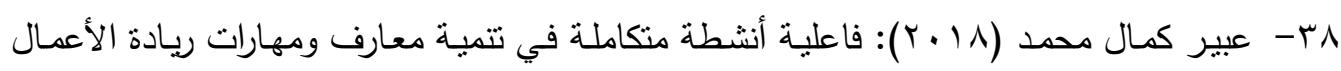

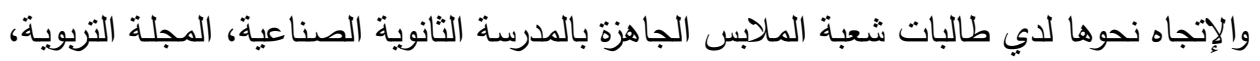

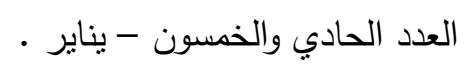

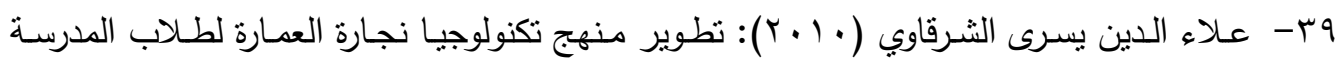
الثانوية الصناعية المعمارية في ضوء توجهات المستقبل، (رسالة دكتوراه، "غير منشورة " ، كلية

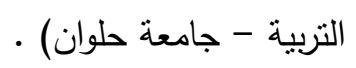
• ـ - عمر زيدان (11 ـ ؟): تأثير السمات الريادية لطلاب الجامعات المصرية على احتمالات إقامتهم

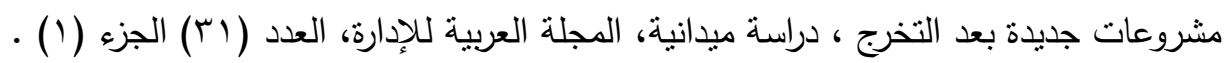

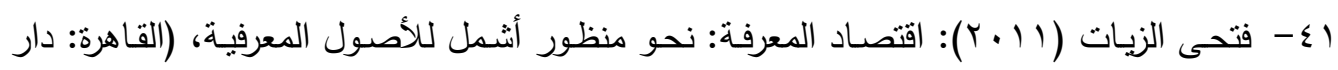
• النشر للجامعات) r - فؤاد أبو حطب (•99 (19)): القدرات العقلية (القاهرة: مكتبة الأنجلو المصرية) .

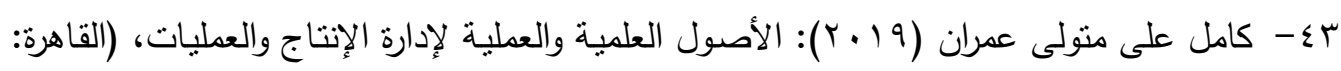

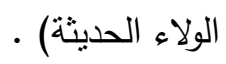

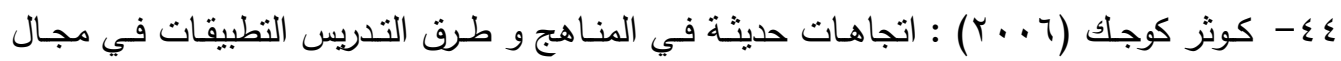

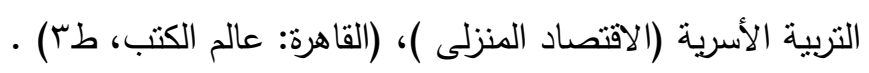

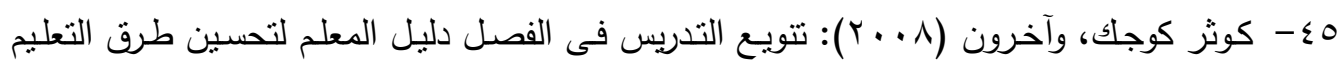
والتعلم فى مدارس الوطن العربى، (بيروت: مكتب اليونسكو الاقليمى للتربية فى الدول العربية) .

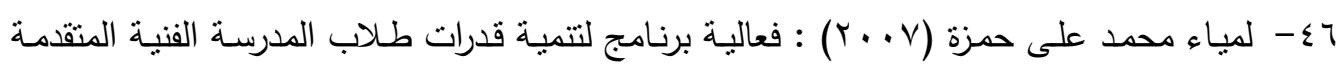
الصناعية فى ضوء مفهوم الجودة الثاملة، (رسالة دكتوراه، غبر منشورة، كلية التربية - جامعة • حلوان) V

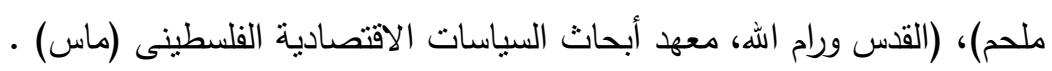

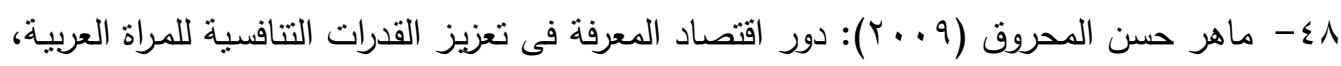

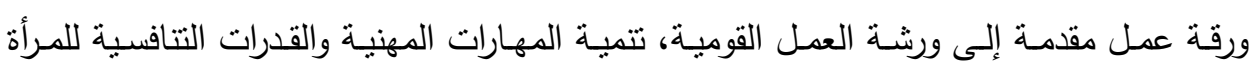

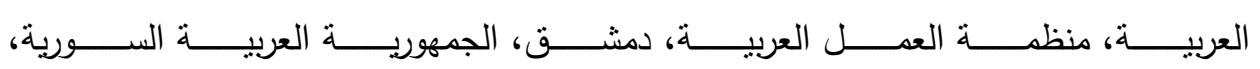
http://infotechaccountants.com 


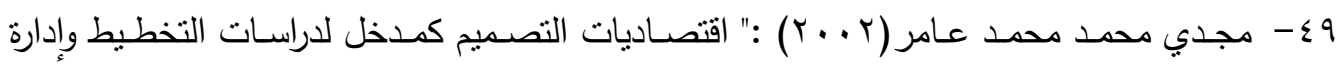
عمليات مشروعات التصميم الداخلي والأسـاس "، (رسـالة دكتوراه، غير منشورة، كليـة الفنون

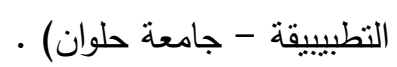

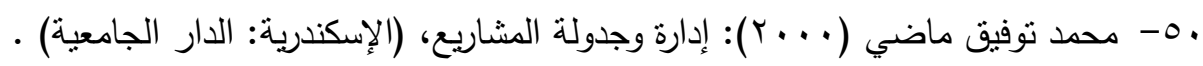

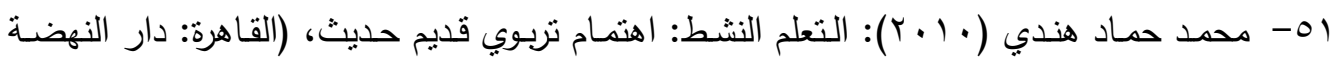
العربية).

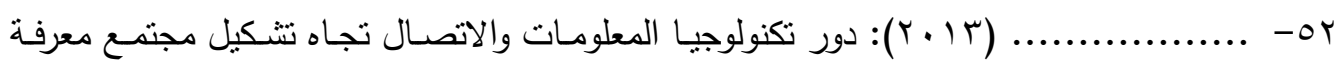

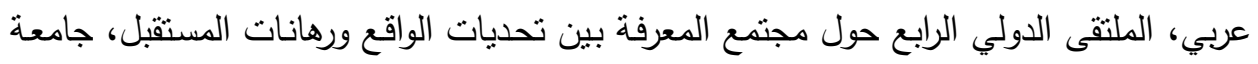

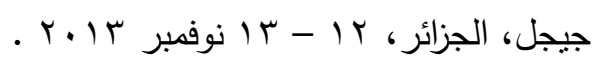

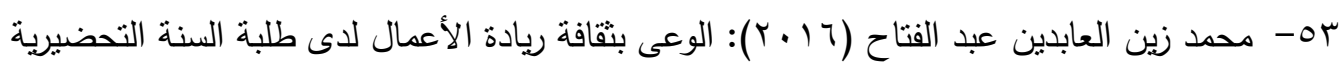

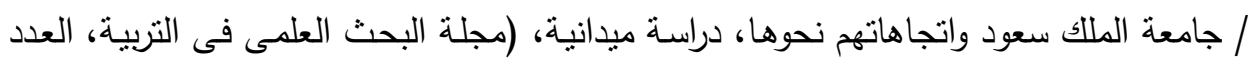
- السابع عشر)

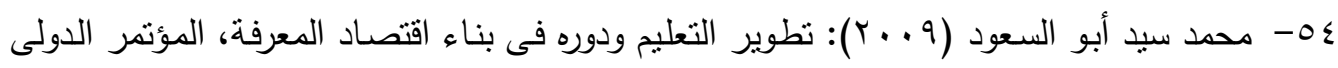

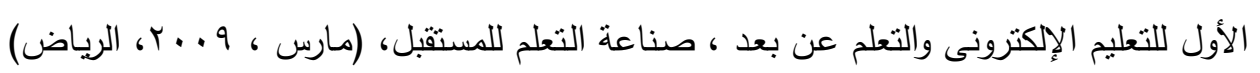
00- محمد عبد العظيم أبو زيد (9 + . ب): صيغة مقترحة لربط التعليم الثانوي الصناعي بسوق العمل

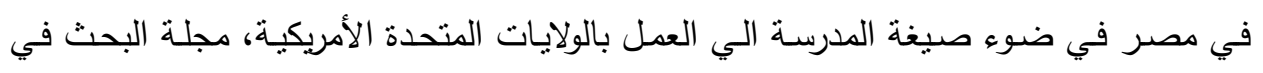
التربية وعلم النفس، عدد ( (1)، جزء (أول)، إبريل، كلية التربية - جامعة المنيا .

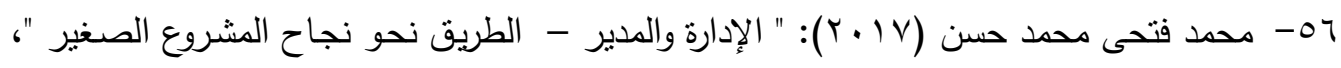
نقابة التجارين بالجيزة، الإصدار العاشر . مدان

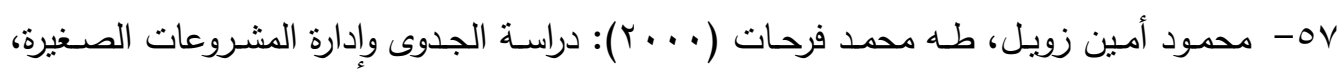

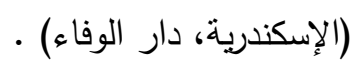
10- محمود محمد (10 • ץ): دراسة المشروعات الصغيرة: مدخل للتتمية المستدامة فى اليابان، (رسالة

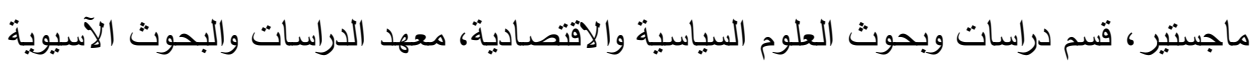

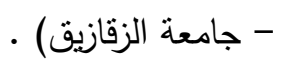


9ه- مراد علة (11 + (1): جاهزية الدول العربية للاندماج فى اقتصاد المعرفة - دراسة نظرية تحليلية المؤنمر العلمي الثامن للاقتصاد والتمويل الإسلاهي، النمو المستدام والتتمية الاقتصادية الثـاملة

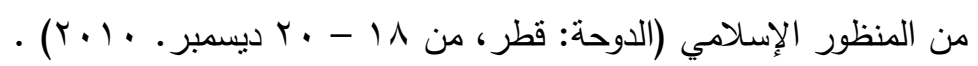

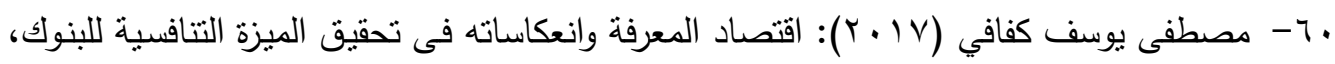

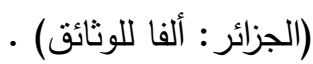

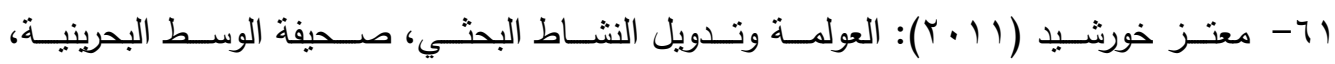

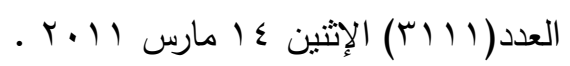

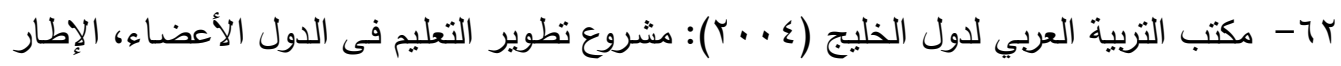

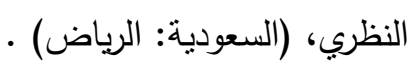

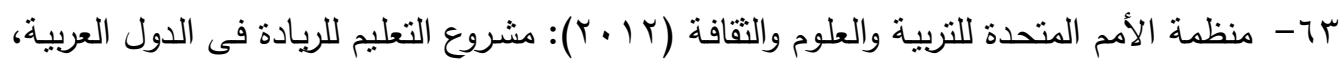

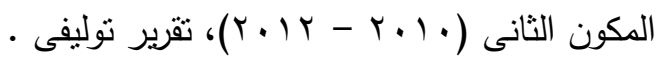

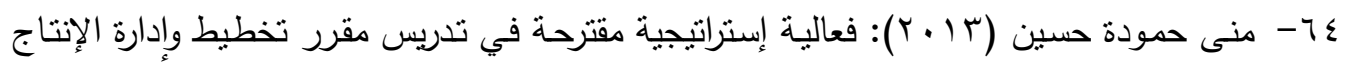

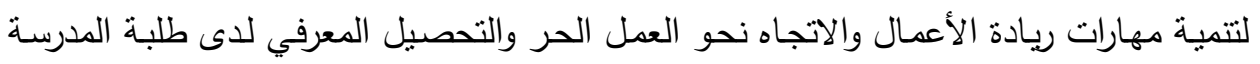

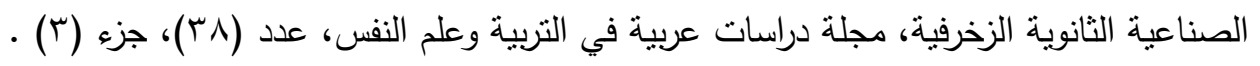

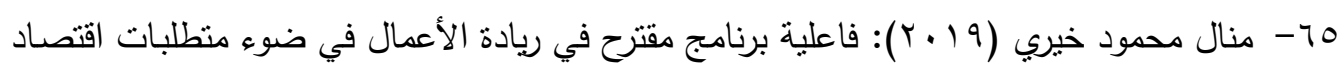

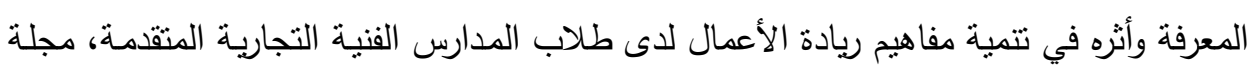

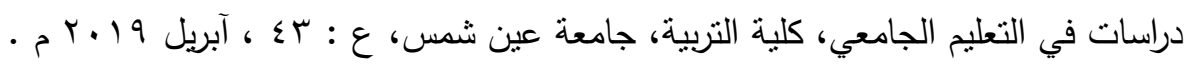

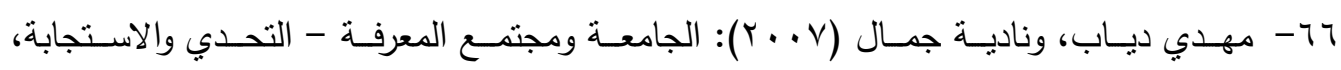

$$
\text { (الإسكندرية: المكتب الجامعي الحديث). }
$$

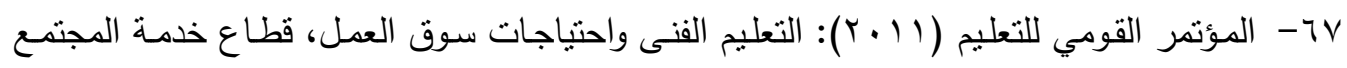
وتتمية البيئة - جامعة بنى سويف.

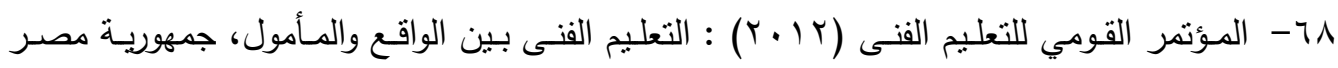

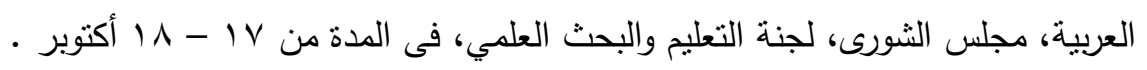

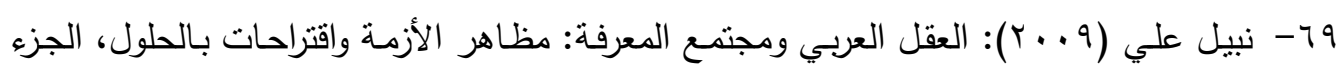

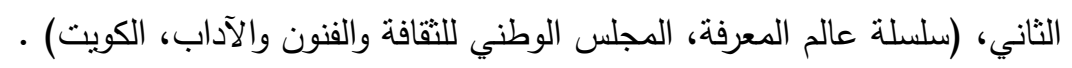

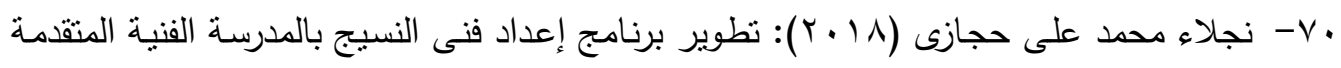

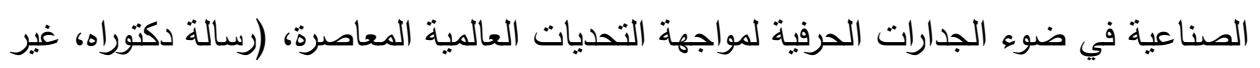

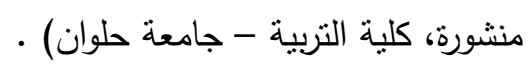




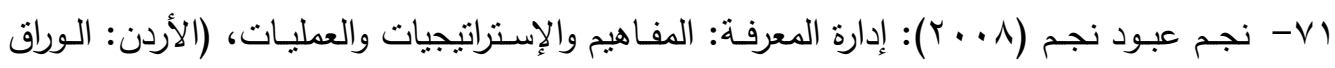
للنشر)

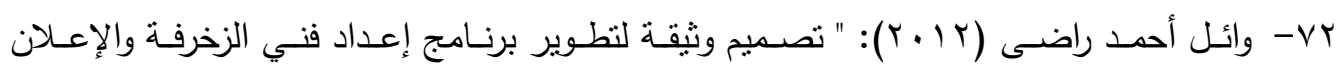

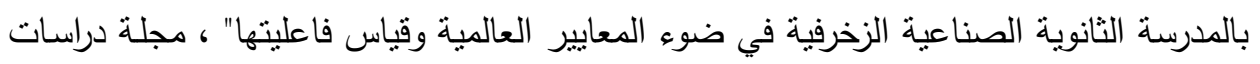

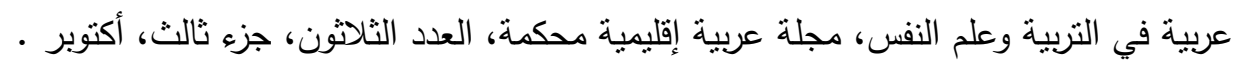

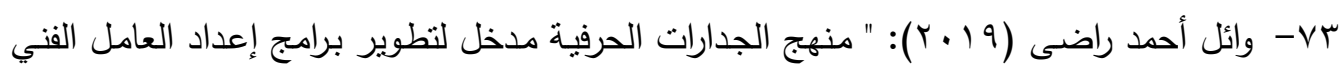

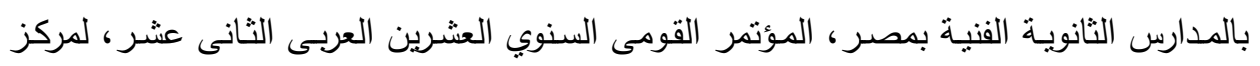

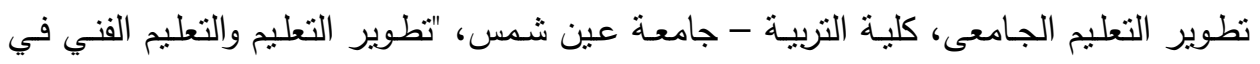

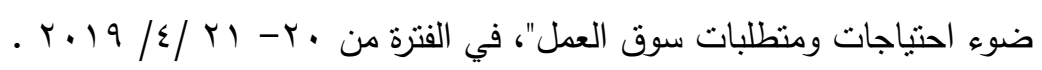

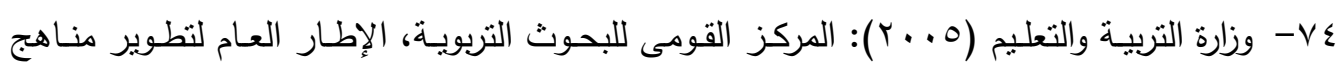
التعليم الفنى.

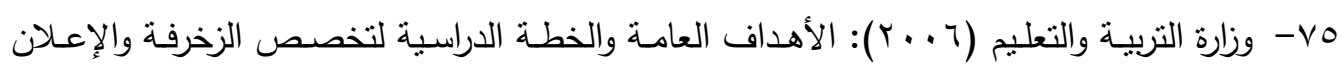

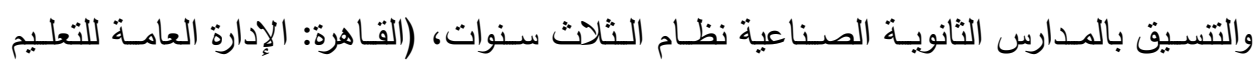
الصناعى)

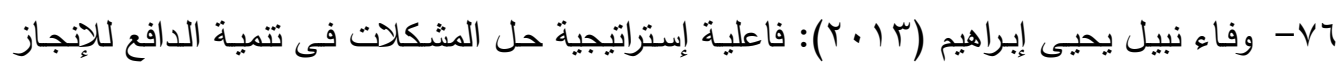

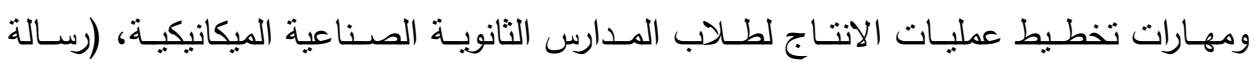

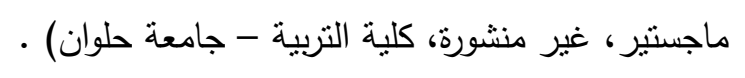

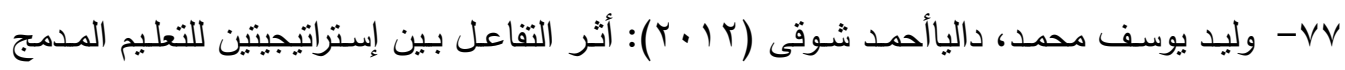
(التقدمى والرجعى) ووجنى الضبط في إكساب مهارات التصميم التعليمى للطـلاب المعلمين

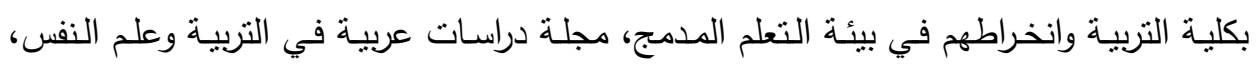

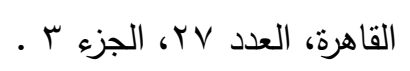

\section{ثانياً: المراجع الأجنيبية:}

1. Arvanitis, Spyri don (2010): E-Learning Programs as Loyalty Investments for Financial Corporations, British Journal of Educational Technology, V4 n5, Sep 2010 .

2. Cristina Fernandez, Jiao Ferreira, Mario Repose, Ricardo Hernández, Juan Carlos Diaz-Caseros, (2017): "Knowledge and entrepreneurship creation: what is the connection?", World Journal of Entrepreneurship, Management and Sustainable Development, Vol. 13 Issue: 1, https://doi.org/10. 
3. Daft,R (2010): New Era of Management. (South Western, Cengage Ed ). th Learning , Australia , 9

4. Data Quality Campaign (2012): Preparing Every Citizen for the Knowledge Economy: A Primer on Using Early Childhood, K-12, Postsecondary \& Workforce Data, Jan 2015 .

5. Donald, Sydney G \& Kneel, Pauline E (2005): Study Skills for Language Students. Oxford University Press, INC, NY, 8th Ed .

6. Gibson,D,Harris,M,L,Mick,T,D, \& Bburkhalter, T,M(2011): Comparing The entrepreneurial Attitudes of University Community College Student, Journal of Higher Education Theory and Practice, 11.

7. Gul, Showkeen \& Bilal, Ahmad. E-Learning Revolution in Education (2015): An Exploratory Study, On Line Submission, Paper Presented at the E-Learning: A Boom on course Conference (Punjab, India, Feb 2015) .

8. Gullet, Janet \& Dinkins, Shivochie (2010): Mississippi Curriculum Framework, Postsecondary Banking and Finance Technology, (Program C.I.P Banking and Financial Support Services), Research and Curriculum Unit, Mississippi Department of Education, Office of Vocational Education and Workforce Development, 2010 .

9. Gustav Hägg, Agnieszka Kurczewska, (2016): "Connecting the dots: A discussion on key concepts in contemporary entrepreneurship education", Education + Training, Vol. 58 Issue: 7/8, https://doi.org/10 .

10. Hana's Arcade (2008): The Evolutions of the Knowledge Economy, the Journal of Regional Analysis Policy, 2008. www.Jrap -journal.org/Past Volumes .

11. Hill, E, S (2011): The Impact of Entrepreneurship Education - An Exploratory Study of MBA Graduates in Ireland, thesis for Degree of Master of Business Studies, university of Limerick .

12. Jay Metra, Y.A. Abu-Bakr, M. Sagagi, (2011): "Knowledge creation and human capital for development: the role of graduate entrepreneurship", Education + Training, Vol. 53 Issue: 5, https://doi.org/10.1108

13. Kenechukwu Ikebuaku, Mulugeta Dinbabo, (2018) "Beyond entrepreneurship education: business incubation and entrepreneurial capabilities", Journal of Entrepreneurship in Emerging Economies, Vol. 10 Issue: 1, https://doi.org/10.1108/JEEE-03-2017-0022

14. Kibry, D, A, \& Ibrahim, N, (2011): Entrepreneurship Education \& the Creation of an Enterprise Culture: Provisional Results from an Experiment in Egypt, International Entrepreneurship and Management Journal, 7 . $(r)$

15. Kivinen, Osmo \& Nurmi, Jouni (2014): Labour Market Relevance of European University Education Form Enrolment to Professional Employment in 12 Countries, European Journal of Education, V49 n4, Dec 2014 . 
16. Kivinen, Osmo \& Nurmi, Jouni (2014): Labour Market Relevance of European University Education Form Enrolment to Professional Employment in 12 Countries, European Journal of Education, V49 n4, Dec 2014 .

17. Lucy Hatt, (2018) "Threshold concepts in entrepreneurship - the entrepreneurs' perspective", Education + Training, Vol. 60 Issue: 2, https://doi.org/10.

18. Martin Toding, Urve Venesaar, (2018): "Discovering and developing conceptual understanding of teaching and learning in entrepreneurship lecturers", Education + Training, Vol. 60 Issue: 7/8, https://doi.org/10.1108/ET-07-2017-0101

19. Metcalfe, J.Stanely (2010): University and Business Relations: Connecting the Knowledge Economy, Minerva: A Review of Science, Learning \& Policy, V48 n1, Mar 2010 .

20. Obielumani, Obielumani Ifakachukwu (2015): A Panoramic View of Some Challenges Inhibiting Access to Higher Education in Developing Countries, Journal of Education \& Practice, V6 n31, 2015.

21. Patricia Vieira's de Castro Krakauer, Fernando Antonio Ribeiro Serra, Martinho Is nard Ribera de Almeida, (2017): "Using experiential learning to teach entrepreneurship: a study with Brazilian undergraduate students", International Journal of Educational Management, Vol. 31 Issue: 7, https://doi.org/10.1108/IJEM-09-2016-0189

22. Rakish Belwal, Hanan Al Balushi, Shweta Belwal, (2015): "Students' perception of entrepreneurship and enterprise education in Oman", Education + Training, Vol. 57 Issue: 8/9, https://doi.org/10.1108/ET-122014-0149

23. Ramasamy Murugesan, Rathinam Jayavelu, (2015): "Testing the impact of entrepreneurship education on business, engineering and arts and science students using the theory of planned behavior: A comparative study", Journal of Entrepreneurship in Emerging Economies, Vol. 7 Issue: 3, https://doi.org/10.

24. Rohit H. Trivedi, (2014): "Are we committed to teach entrepreneurship in business school?: An empirical analysis of lecturers in India, Singapore and Malaysia", Journal of Enterprising Communities: People and Places in the Global Economy, Vol. 8 Issue: 1, https://doi.org/10.1108/JEC-082013-0026

25. Sam, Chanphirun \& Van Der Sijde (2014): Peter. Understanding the Concept of The Entrepreneurial University from The Perspective of Higher Education Model, Higher Education: The International Journal of Higher Education and Educational Planning, V68 n6, Dec 2014. 
26. Santiago, Deborah \& Soliz, Megan (2012): Finding Your Workforce: The Top 25 Institutions Graduation Latinos First in A Series Linking College Completion With U.S Workforce Need, Excellences in Education, 2012.

27. Tiana Järvi, (2015): "Production of entrepreneurship in small business activities of students", Journal of Small Business and Enterprise Development, Vol. 22 Issue: 1, https://doi.org/10.1108/JSBED-02-20120023

28. Yagoub Ali Gangi, (2017): "The role of entrepreneurship education and training on creation of the knowledge economy: Qatar leap to the future", World Journal of Entrepreneurship, Management and Sustainable Development, Vol. 13 Issue: 4, https://doi.org/10.1108/WJEMSD-0620170032. 